FERNANDO LUIZ AGUIAR FILHO

\title{
MODELO INSTITUCIONAL DO SETOR ELÉTRICO BRASILEIRO: ANÁLISE DA CAPACIDADE DE ATRAÇÃO DE CAPITAL PRIVADO PARA INVESTIMENTOS EM GERAÇÃO DE ENERGIA HIDRELÉTRICA
}




\section{FERNANDO LUIZ AGUIAR FILHO}

\section{MODELO INSTITUCIONAL DO SETOR ELÉTRICO BRASILEIRO: ANÁLISE DA CAPACIDADE DE ATRAÇÃO DE CAPITAL PRIVADO PARA INVESTIMENTOS EM GERAÇÃO DE ENERGIA HIDRELÉTRICA}

Dissertação apresentada à Escola Politécnica da Universidade de São Paulo para Obtenção do Título de Mestre em Engenharia.

Área de Concentração: Engenharia de Construção Civil Urbana

Orientador:

Prof. Dr. Claudio Tavares de Alencar 


\section{AGRADECIMENTOS}

Aos docentes do Grupo de Real Estate, por me despertarem para o tema da "Análise dos Investimentos no Setor da Construção Civil'".

Ao Prof. Dr. Claudio Tavares de Alencar pela confiança e prontidão e pela orientação precisa e elucidativa.

Ao Prof. Dr. João da Rocha Lima Junior, Prof. Dr. Dorel Soares Ramos e Dr. Roberto Castro pelas valiosas contribuições.

Ao M.E. Paulo Chiara, pelo incentivo e pelas contribuições na fase inicial de desenvolvimento do trabalho.

À Ana Paula, pela compreensão e pelas renúncias que acabou por fazer em nome desta dissertação.

À toda minha família, sempre tão presente em tudo o que faço. Às minhas irmãs Carolina e Lívia e, em especial, aos meus pais, Fernando e Angélica, pelo incentivo, por tudo o que me ensinam e por darem todas as condições para que eu me dedicasse, à minha vontade, ao desenvolvimento desta dissertação.

Aos amigos da Camargo Corrêa e a todos que, de alguma forma, contribuíram para a conclusão deste trabalho.

A Deus. 


\section{RESUMO}

Em março de 2004, o governo brasileiro aprovou as leis 10.847 e 10.848 , que alteram as bases da regulação do Setor Elétrico Brasileiro. As leis instituíram novas regras para a outorga de concessões para aproveitamentos hidrelétricos e para comercialização de energia entre agentes de geração, distribuidores e comercializadores de energia elétrica. Diante da contínua demanda por investimentos na expansão da capacidade de geração, este trabalho foi desenvolvido com o objetivo de inferir sobre a capacidade do modelo institucional vigente de atrair capital privado para investimentos em geração de energia hidrelétrica. A inferência é realizada a partir da análise dos resultados dos leilões de energia nova realizados em 2005 e 2006 e da simulação do investimento em um protótipo de empreendimento de geração de energia hidrelétrica. De forma geral, as mudanças regulatórias favorecem o fluxo de investimentos para empreendimentos de geração hidrelétrica. Contudo, mais do que a um modelo institucional sólido, a derivação de investimentos para este segmento estará condicionada à ação do Estado sobre o equilíbrio entre consumo, oferta e preços de energia, enquanto principal artífice da política energética nacional.

Palavras Chaves: Energia Elétrica. Usina Hidrelétrica. Capital Privado. Análise de Investimentos. Modelo Regulatório. 


\begin{abstract}
In March 2004, the Brazilian Government passed the laws 10.847 and 10.848, which changed the regulatory guidelines of electric market. The laws established new rules for granting hydroelectric exploitation rights and for energy purchasing, among distributors, new generators and free consumers. In front of the new regulatory basis and the Brazilian demand for installed capacity increase, this research aims to infer the capacity of regulatory basis to attract private recourses for investments on hydroelectric power projects. The inference will be developed based on the results of auctions of electricity from new power plants, occurred in 2005 and 2006, and on the simulation of the investment on a prototype of a hydroelectric project in Brazil. The final remarks show that the new electric model favor the investment flow to hydroelectric power plants. However, more than to a solid institutional model, the investments on this segment will be conditioned to the Government action on the equilibrium between energy consuming, offering and prices, as the main agent of the national energy politics.
\end{abstract}

Keywords: Electric Energy. Hydroelectric Power Plant. Investment Analysis. Private Capital. Regulation Model. 


\section{SUMÁRIO}

1. INTRODUÇÃO

2. HISTÓRICO DE REGULAÇÃO DO SETOR ELÉTRICO................................................................5

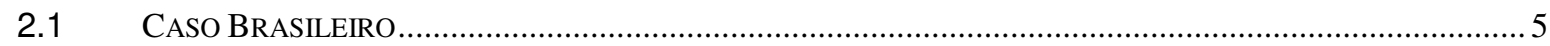

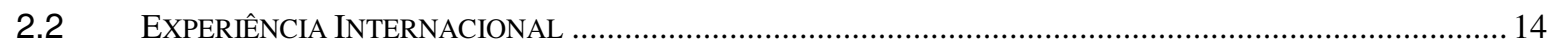

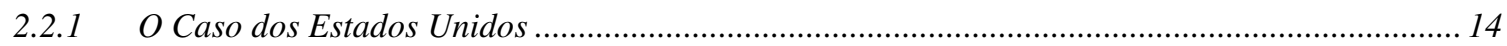

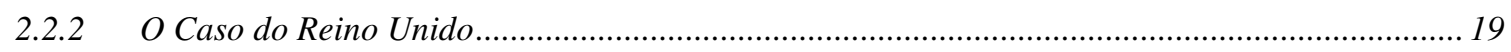

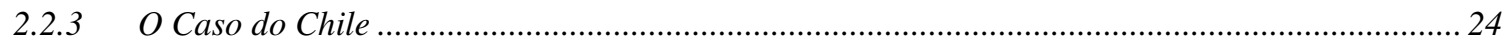

3. NOVO MODELO DO SETOR ELÉTRICO BRASILEIRO .............................................................2 27

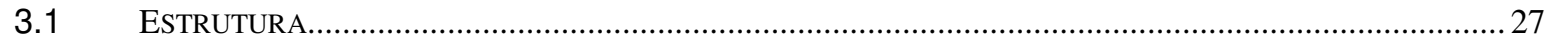

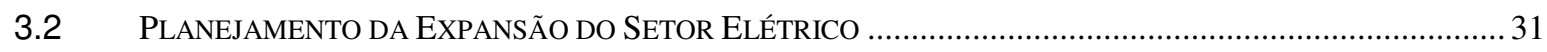

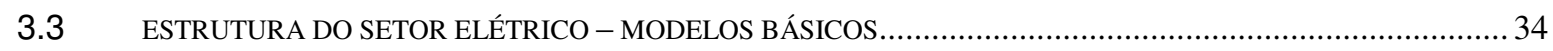

3.4 A OPERAÇÃO CENTRALIZADA Do SISTEMA DE TRANSMISS Ão............................................................ 41

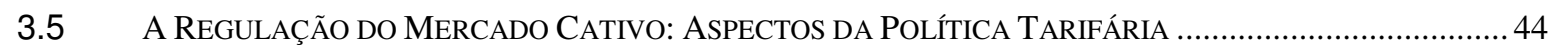

3.6 A CONCESSÃo DE Novos APROVEITAMENTOS E A CONTRATAÇÃO DE ENERGIA................................. 49

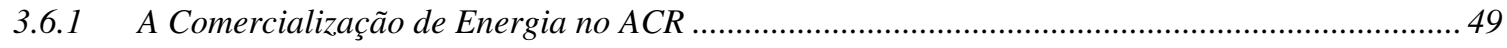

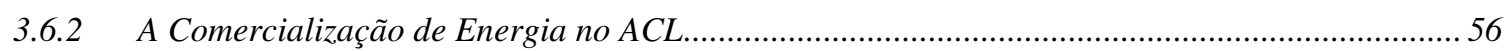

3.6.3 A Comercialização de Energia no Mercado de Curto Prazo ……………………………….........57

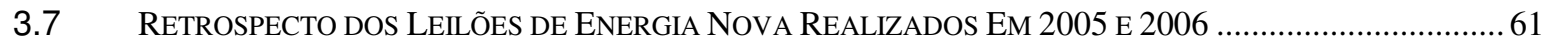

4. EMPREENDIMENTOS DE GERAÇÃO DE ENERGIA HIDRELÉTRICA: CARACTERÍSTICAS

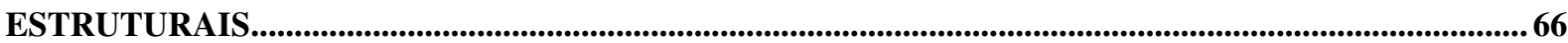

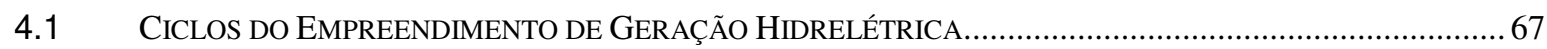

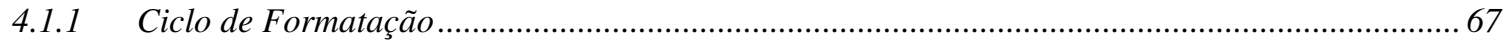

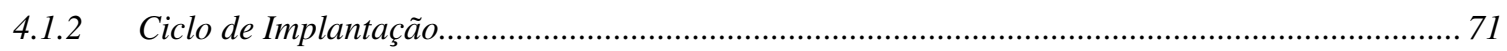

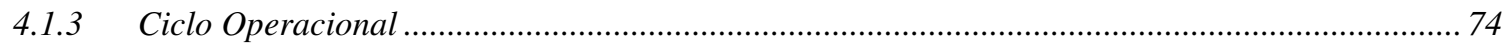

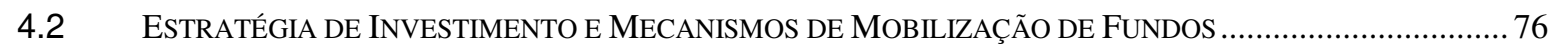

4.2.1 Project Finance como Estratégia de Investimento .......................................................................... 76

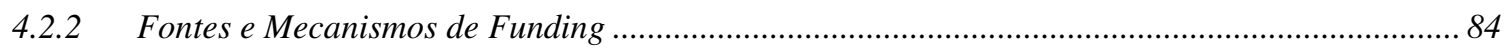

4.3 RisCos DA ATIVIDADE DE GERAÇÃo DE ENERGIA HidRELÉTRICA ..................................................... 95

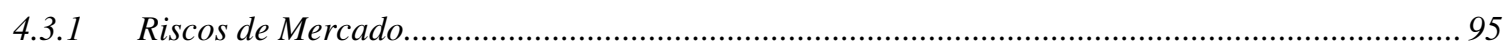

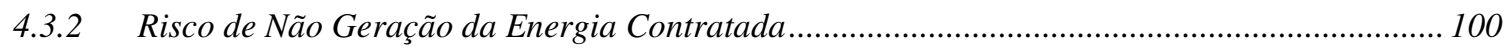

4.3.3 Riscos de Inadimplência do Agente Comprador ................................................................... 103

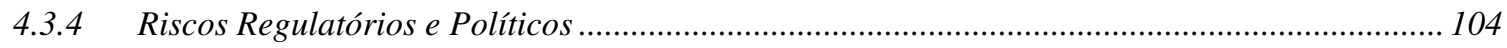

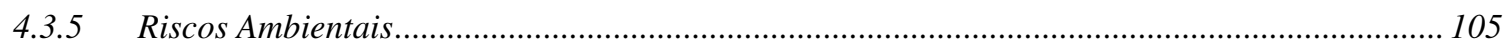

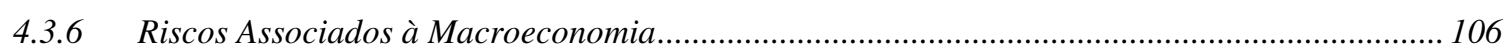

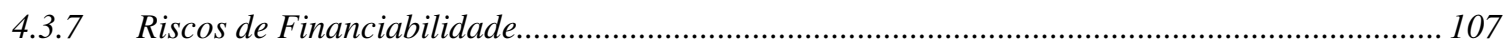




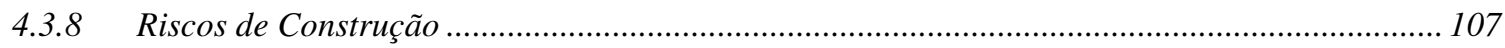

4.3.9 Riscos de Operação e Manutenção ................................................................................................ 108

5. EMPREENDIMENTOS DE GERAÇÃO DE ENERGIA HIDRELÉTRICA: ANÁLISE DA

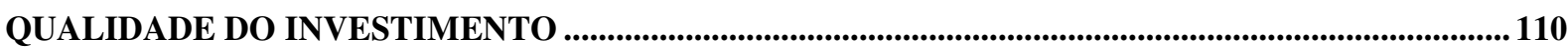

5.1 ANÁLISE DA QUALIDADE DO INVESTIMENTO - ABORDAGEM METODOLÓGICA................................. 110

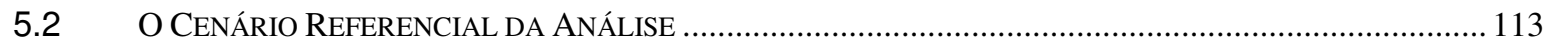

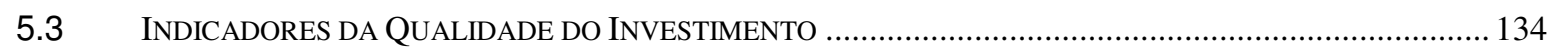

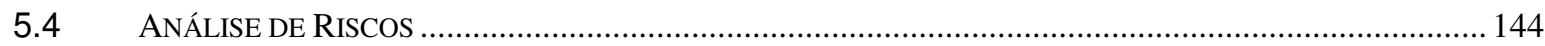

5.4.1 Análise de Risco de Efeitos Discretos........................................................................... 145

5.4.2 Análise de Risco de Efeitos Cruzados........................................................................................ 159

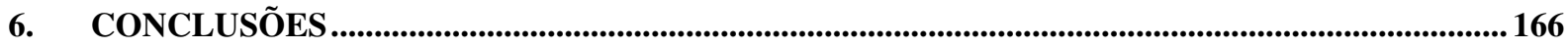

ANEXO A - CARACTERÍSTICAS DOS EMPREENDIMENTOS CONCEDIDOS EM DEZ/05 E OUT/06 172

ANEXO B - FLUXO DE CAIXA DO EMPREENDIMENTO PROTÓTIPO ......................................... 173

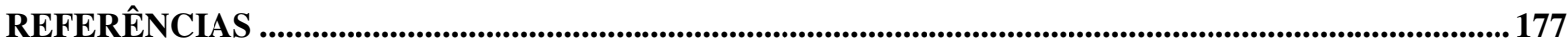

REFERÊNCIAS COMPLEMENTARES .......................................................................................... 183 


\section{LISTA DE FIGURAS}

Figura 2.1 - Relação Histórica entre o Preço e o Armazenamento da Energia (Região Sudeste) 10

Figura 3.1 - Estrutura Institucional do Setor Elétrico 28

Figura 3.2 - Ambientes de Comercialização de Energia Elétrica 29

Figura 3.3 - Modelo de Monopólio Vertical 35

Figura 3.4 - Modelo de um Único Comprador 36

Figura 3.5 - Modelo de Competição na Comercialização 36

Figura 3.6 - Modelo de Competição no Nível do Consumo 37

Figura 3.7 - Transição entre Modelos de Organização do Setor Elétrico 37

Figura 3.8 - Leilões de Comercialização de Energia Elétrica 50

Figura 3.9 - Mecanismo de Realocação de Energia - MRE 60

Figura 3.10 - Mercado de Curto Prazo 60

Figura 4.1 - Ciclos do Empreendimento Hidrelétrico 67

Figura 4.2 - Estrutura Genérica Project Finance - Empreendimento Hidrelétrico 80

Figura 5.1 - Ciclos do Empreendimento Protótipo 114

Figura 5.2 - Cronograma de Funding 127

Figura 5.3 - Curva de Formação da TIR 139

Figura 5.4 - Fluxo Investimento x Retorno Acumulado 140

Figura 5.5 - TIR x Alavancagem, alternando a composição da equação de fundos 143

Figura 5.6 - Desvios no Custo de Implantação 147

Figura 5.7 - TIR x Custo de Implantação, variando Preço de Energia 148

Figura 5.8 - Atraso na Entrada em Operação Comercial 150

Figura 5.9 - Desvios no Custo de Operação e Manutenção 151

Figura 5.10 - Quebra na Quantidade de Energia Disponível 153

Figura 5.11 - Flutuação Dispersa da Energia Disponível 154

Figura 5.12 - Variações de Preço no ACR 155

Figura 5.13 - Variação da Exposição no ACL 157

Figura 5.14 - Distúrbios Macroeconômicos 158

Figura 5.15 - Flutuação Dispersa e Cruzada da Quantidade de Energia Disponível e Preços 160

Figura 5.16 - Flutuação Dispersa do Conjunto de Variáveis - Impacto na TIR dos TIEE-A2 162

Figura 5.17 - Flutuação Dispersa do Conjunto de Variáveis - Impacto na TIR do Empreendedor 163 


\section{LISTA DE TABELAS}

Tabela 3.1 - Distribuição do Consumo de Energia Elétrica 40

Tabela 3.2 - Composição da Receita Requerida pelos Distribuidores 45

Tabela 5.1 - Características Gerais da UHE Protótipo 115

Tabela 5.2 - Inserção de Mercado do Empreendimento 118

Tabela 5.3 - Programa de Implantação 119

Tabela 5.4 - Custos de Implantação 120

Tabela 5.5 - Condições do Financiamento do BNDES 122

Tabela 5.6 - Condições das Emissões dos Títulos de Dívida 126

Tabela 5.7 - Contas de Operação 131

Tabela 5.8 - Cenário Macroeconômico 133

Tabela 5.9 - Indicadores da Qualidade no Cenário Referencial 137

Tabela 5.10 - Fronteiras de Comportamento para Análise de Risco de Efeitos Discretos 146

Tabela 5.11 - Relação [Energia Gerada / Energia Assegurada] do Sistema Hídrico 154

Tabela 5.12 - Fronteiras de Flutuação para Análise de Risco de Efeitos Cruzados 159 


\section{LISTA DE ABREVIATURA E SIGLAS}

ABRACE

ACL

ACR

ANA

ANEEL

ANP

BID

BNDES

$\mathrm{CCC}$

CCEAR

CCEE

CCG

CCT

$\mathrm{CDE}$

CDEC

CDI

CEGB

CIRR

CMO

CMSE

CNPE

COFURH

cop

CPST

CRC

CSLL

CUST

CVM

EBITDA
- Associação Brasileira de Grandes Consumidores Industriais de Energia e Consumidores Livres

- Ambiente de Contratação Livre

- Ambiente de Contratação Regulada

- Agência Nacional de Águas

- Agência Nacional de Energia Elétrica

- Agência Nacional do Petróleo

- Banco Interamericano de Desenvolvimento

- Banco Nacional de Desenvolvimento Econômico e Social

- Conta de Consumo de Combustíveis

- Contrato de Comercialização de Energia Elétrica no Ambiente Regulado

- Câmara de Comercialização de Energia Elétrica

- Contrato de Constituição de Garantia

- Contrato de Conexão ao Sistema de Transmissão

- Conta de Desenvolvimento Energético

- Centro de Despacho Económico de Carga

- Certificado de Depósito Interbancário

- Central Electricity Generating Board

- Commercial Interest Reference Rates

- Custo Marginal de Operação

- Comitê de Monitoramento do Setor Elétrico

- Conselho Nacional de Política Energética

- Compensação Financeira pelo Uso do Recurso Hídrico

- Custo de Oportunidade

- Contrato de Prestação de Serviços de Transmissão

- Conta de Resultados a Compensar

- Contribuição Social sobre o Lucro Líquido

- Contrato de Uso do Sistema de Transmissão

- Comissão de Valores Mobiliários

- Earnings before Interests, Taxes, Depreciation and Amortization 


\begin{tabular}{|c|c|}
\hline ECA & - Export Credit Agencies \\
\hline EIA & - Estudo de Impacto Ambiental \\
\hline ELETROBRÁS & - Centrais Elétricas Brasileiras S.A. \\
\hline EPE & - Empresa de Pesquisa Energética \\
\hline EWG & - Exempt Wholesale Generator \\
\hline FERC & - Federal Energy Regulatory Commission \\
\hline FIP & - Fundo de Investimentos em Participações \\
\hline GCE & - Câmara de Gestão da Crise Energética \\
\hline GCOI & - Grupo Coordenador de Operação Interligada \\
\hline IBAMA & - Instituto Brasileiro do Meio Ambiente e dos Recursos Naturais \\
\hline & Renováveis \\
\hline ICSD & - Índice de Cobertura do Serviço da Dívida \\
\hline IFC & - International Finance Corporation \\
\hline IGP-M & - Índice Geral de Preços de Mercado \\
\hline IPCA & - Índice de Preços ao Consumidor Amplo \\
\hline IR & - Imposto de Renda \\
\hline IRT & - Índice de Reajuste Tarifário Anual \\
\hline ISC & - Índice Setorial da Construção \\
\hline ISEE & - Índice Setorial de Operação e Manutenção de Usinas Hidrelétricas \\
\hline ISO & - Independent System Operator \\
\hline LIBOR & - London Interbank Offered Rates \\
\hline MME & - Ministério das Minas e Energia \\
\hline MRE & - Mecanismo de Realocação de Energia \\
\hline MRT & - Margen de Reserva Teórico \\
\hline NE & - Nuclear Electric \\
\hline NETA & - New Electricity Trading Arrangement \\
\hline NGC & - National Grid Company \\
\hline NP & - National Power \\
\hline NTN-B & - Notas do Tesouro Nacional - série B \\
\hline OECD & - Organisation for Economic Co-operation and Development \\
\hline ONS & - Operador Nacional do Sistema Elétrico \\
\hline PAC & - Programa de Aceleração do Crescimento \\
\hline $\mathrm{PCH}$ & - Pequena Central Hidrelétrica \\
\hline$P \& D$ & - Taxa de Pesquisa e Desenvolvimento e Eficiência Energética \\
\hline
\end{tabular}


PDE

PDET

PELP

PG

PLD

PROINFA

PUC

PX

RGR

RE-SEB

RIMA

RTE

SAC

SIN

SND

SPE

TAR

tat

TFSEE

TIEE-A1

TIEE-A2

TIR

TJLP

TUSD

TUST

UBP

UHE

VN

VR
- Plano Decenal de Expansão dos Sistemas Elétricos

- Programa Determinativo de Expansão da Transmissão

- Plano de Expansão de Longo Prazo do Setor Elétrico

- Power Gen

- Preço de Liquidação das Diferenças

- Programa de Incentivo às Fontes Alternativas de Energia Elétrica

- Public Utilities Commission

- Power Exchange

- Reserva Global de Reversão

- Projeto de Reestruturação do Setor Elétrico Brasileiro

- Relatório de Impacto Ambiental

- Revisão Tarifária Extraordinária

- Sistema de Amortização Constante

- Sistema Interligado Nacional

- Sistema Nacional de Debêntures

- Sociedade de Propósito Específico

- Tarifa Anual de Referência

- Taxa de Atratividade

- Taxa de Fiscalização dos Serviços de Energia Elétrica

- Títulos de Investimento em Energia Elétrica - tipo A1

- Títulos de Investimento em Energia Elétrica - tipo A2

- Taxa Interna de Retorno

- Taxa de Juros de Longo Prazo

- Tarifa de Uso do Sistema de Distribuição

- Tarifa de Uso do Sistema de Transmissão

- Uso do Bem Público

- Usina Hidrelétrica

- Valor Normativo

- Valor Anual de Referência 


\section{INTRODUÇÃO}

O Estado, enquanto agente arrecadador e, historicamente, o promotor do desenvolvimento da infra-estrutura nacional, experimentou, a partir de fins da década de 80, uma expressiva redução de sua capacidade financeira e operacional para o desenvolvimento de empreendimentos intensivos em capital.

A redução da capacidade estatal, combinada ao dever constitucional de promover a expansão e a prestação adequada de serviços públicos, tornou necessária a criação de mecanismos alternativos ao financiamento estatal, para sustentar investimentos na implantação e operação da infra-estrutura.

No setor elétrico, a redução da capacidade financeira do Estado representou o fim do modelo de financiamento setorial sustentado, de forma preponderante, por recursos públicos. Desde meados da década de 90, o setor elétrico brasileiro passa por um processo de reformas, cujo fim parece convergir para redução da dimensão do Estado empresário e ajuste da estrutura do setor ao ingresso de investimentos privados, de forma a reservar, ao ente público, os papéis de regulador, fiscalizador, mediador e formulador de políticas.

A década de 90 marcou a transição de um modelo fortemente estatal, de concessionárias públicas verticalmente integradas e financiamento baseado na arrecadação físcal e no endividamento de empresas estatais, para um modelo de maior abertura aos investimentos privados e à competição.

Os marcos do processo de reestruturação do setor, a exemplo do caminho percorrido por países de vanguarda na reforma do setor elétrico, foram: (i) a criação da Agência Nacional de Energia Elétrica (ANEEL) e uma conseqüente maior separação entre as funções de regulador e poder concedente; (ii) os movimentos de desverticalização das atividades de Geração, Transmissão e Distribuição, com redução de subsídios intra-setoriais opostos à competição; (iii) criação da figura do Produtor Independente de Energia Elétrica, concessionários da exploração de aproveitamentos hidrelétricos e usinas termelétricas com prerrogativa para livre comercialização da energia produzida; (iv) criação do mercado livre e da figura do agente de 
comercialização, liberando os grandes consumidores para contratação da energia diretamente do agente produtor, localizado em qualquer região do Brasil, desde que conectado ao sistema interligado e (v) criação do Operador Nacional do Sistema (ONS), para a coordenação centralizada do despacho energético e regulamentação do acesso às redes de transmissão.

Em 2004, com a aprovação das leis 10.847 e 10.848, novas mudanças nas bases regulatória e institucional do setor elétrico foram instituídas. Em linhas gerais, as disposições do novo marco legal primaram pela reorganização das atividades de planejamento, a partir da reestruturação institucional do setor, e pela regulação sobre o processo de comercialização de energia no mercado cativo, de forma a ajustar a política setorial aos objetivos de modicidade tarifária, de incentivo aos investimentos privados e de segurança de abastecimento.

Entre as disposições estruturais do marco regulatório estão: (i) a adoção do menor preço da energia destinada ao mercado cativo, como critério de julgamento dos processos de licitação de novos aproveitamentos hídricos e de contratação de energia de fonte hídrica e térmica (ii) a obrigação do estabelecimento dos Contratos de Comercialização de Energia Elétrica no Ambiente Regulado (CCEAR's), entre produtores de energia e concessionárias de serviços públicos de distribuição de energia elétrica. Os CCEAR's, para energia hídrica proveniente de empreendimentos novos, têm prazo de 30 anos e são firmados com antecedência de três a cinco anos antes do início de suprimento, com preço fixo, definido em processo de leilão.

De modo geral, as mudanças nas regras de concessão de novos aproveitamentos e comercialização de energia alteraram a estrutura dos negócios desenvolvidos no setor e, portanto, a percepção sobre os riscos dos investimentos em empreendimentos de geração de energia hidrelétrica.

Os empreendimentos deste segmento guardam em sua estrutura as características dos negócios intensivos em capital, desenvolvidos no setor de infra-estrutura. Os empreendimentos respeitam dois ciclos definidos, de características marcantes. Na fase de implantação, demandam intenso e concentrado fluxo de investimentos e, na fase de operação, registram elevada geração de caixa, em fluxos de baixa flutuação e diferidos em longos períodos. 
A condição de risco, derivada das disposições regulatórias vigentes e das características estruturais do segmento, torna o produto de investimento associado ao empreendimento de geração de energia hidrelétrica peculiar no aspecto da configuração dos fluxos de investimento e retorno e da condição Rentabilidade $x$ Risco a eles associada.

Apoiado nesta premissa, propõe-se a dissertação com objetivo de auscultar sobre a capacidade do modelo regulatório vigente de atrair capital privado para empreendimentos de geração de energia hidrelétrica. A análise será baseada nos resultados dos leilões de energia nova realizados em 2005 e 2006 e na simulação de um protótipo de empreendimento de geração de energia hidrelétrica, que permite reconhecer a imagem da qualidade do investimento em geração de energia hidrelétrica, no atual ambiente do setor elétrico.

Em outros termos, o propósito da simulação através do protótipo é produzir indicadores da qualidade do investimento em geração de energia hidrelétrica, de forma que, um investidor habituado ou não ao aporte de recursos no setor, possa tomar a decisão de investir, ao hierarquizar o investimento em geração frente a outras alternativas à sua disposição.

A análise será desenvolvida, considerando o ponto de vista de dois tipos de investidores, o investidor especialista que tem em sua atividade fim a exploração do empreendimento hidrelétrico e o investidor não especialista, que não está habituado ao investimento em empreendimentos no setor, mas que enxerga-o como destino alternativo, na economia, aos recursos de que dispõe. Seja sob o ponto de vista do investidor especialista ou não especialista, a hipótese é que o aporte de recursos esteja lastreado exclusivamente na qualidade do empreendimento hidrelétrico, amparado em seu próprio desempenho, tendo por base o project finance, enquanto estratégia de investimento.

Esta dissertação se desenvolve ao longo de cinco capítulos. O primeiro capítulo constitui a presente introdução.

O segundo capítulo introduz o tema reestruturação do setor elétrico, a partir da revisão histórica do processo de desenvolvimento, regulação e financiamento do setor elétrico no Brasil e da análise referencial de expoentes internacionais em seus processos de reforma. 
O terceiro capítulo contém uma descrição pormenorizada do modelo brasileiro, instituído pelas leis 10.847 e 10.848. Na descrição do modelo vigente, serão explorados, com maior ênfase, os aspectos associados à organização institucional e operacional do setor elétrico brasileiro e às mudanças estruturais nas bases da relação entre geradores e concessionários de serviços de distribuição de energia elétrica.

O quarto capítulo contém a discussão acerca da estrutura dos empreendimentos de geração de energia hidrelétrica e divide-se em três seções. A primeira seção traz uma caracterização dos ciclos de formatação, implantação e operação do empreendimento hidrelétrico, que permite reconhecer o formato peculiar destes empreendimentos. A segunda seção apresenta o project finance como estratégia de investimento e elenca os principais mecanismos e fontes para mobilização de recursos para o setor. Por fim, na última seção discute-se os riscos do investimento em empreendimentos hidrelétricos.

No quinto capítulo é desenvolvida a análise da qualidade, através da qual se produzirão indicadores da qualidade do investimento, do ponto de vista de rentabilidade, liquidez e segurança. A análise é feita através de um protótipo de empreendimento hidrelétrico, formatado com base nos parâmetros extraídos do conjunto de empreendimentos concedidos, no Brasil, em 2005 e 2006, nos leilões de concessão de novos aproveitamentos hidrelétricos. 


\section{HISTÓRICO DE REGULAÇÃO DO SETOR ELÉTRICO}

\subsection{CASO BRASILEIRO}

Durante as décadas de 60, 70 e 80, o setor elétrico brasileiro organizou-se segundo uma estrutura caucada na atuação de grandes empresas elétricas de controle estatal, nas esfera federal - controladas pela holding Centrais Elétricas Brasileiras S.A. (ELETROBRÁS) - e estadual. Neste período, o financiamento do setor manteve-se baseado no autofinanciamento, ou na reinversão de resultados gerados na operação setorial, no endividamento externo, no financiamento fiscal e, em menor escala, nos aportes estatais.

No início da década de 80, na esteira de um período de forte recessão e crises em economias internacionais, o modelo estatal de financiamento setorial começou a apresentar sinais de esgotamento. Os investimentos no setor declinaram a partir do ano de 1982, como reflexo da escassez de crédito no mercado internacional, da utilização recorrente, pelo governo federal, de atrasos nos reajustes das tarifas de serviços públicos, como forma de conter o processo inflacionário, e da redução de aportes orçamentários pela União e Estados no setor.

Naquele período, os custos de financiamento dispararam, em um momento em que os empréstimos tornaram-se a principal fonte de financiamento do setor. A rolagem dos compromissos financeiros e o conseqüente aumento da parcela de serviço de dívida no balanço setorial fizeram com que a década de 80 terminasse com a necessidade de se encontrar novos mecanismos para o equacionamento financeiro de empreendimentos do setor.

A primeira metade da década de 90 foi marcada pela gênese da privatização de ativos e serviços públicos no Brasil. A privatização potencialmente solucionaria dois pontos cruciais da política econômica pública: (i) o endividamento do governo e das estatais, pois os recursos obtidos nos leilões seriam utilizados para abatimento da dívida, e (ii) a necessidade de investimentos na expansão e prestação de serviços públicos, tanto dos serviços privatizados, considerando a maior capacidade do agente privado para aplicação e gestão de recursos 
financeiros, como dos serviços cuja operação seria mantida sob a égide estatal, uma vez que a privatização liberaria recursos orçamentários.

No setor elétrico, o plano de privatização priorizou a venda das concessionárias de distribuição, pois considerou-se que dificilmente se atrairiam investidores para os ativos de geração, caso não fosse criado previamente um mercado privado de energia, que trouxesse maior qualidade ao crédito no segmento de distribuição e reduzisse os riscos sobre o processo de comercialização de energia elétrica, aos olhos dos potenciais investidores privados em geração.

Segundo CASTRO (2004), entre 1990 e 2002, com o processo de privatização, parte significativa das empresas de distribuição - cerca de $84 \%$ de toda a energia distribuída - e uma parcela das empresas geradoras, cerca de $32 \%$ da potência instalada no país, foram vendidos para iniciativa privada.

O movimento de venda de ativos estatais foi o embrião da reestruturação do setor elétrico brasileiro iniciada na década de 90. Em termos legais, o marco da reestruturação do setor elétrico brasileiro foi 1993, com a promulgação da Lei Eliseu Resende (Lei 8.631/93), que estabeleceu, entre outros:

- o fim da equalização tarifária ${ }^{1}$;

- a extinção da remuneração garantida;

- o acerto de contas com a Conta de Recursos a Compensar (CRC) $)^{2}$ e

- a obrigatoriedade de estabelecimento de contratos de suprimento entre geradores e distribuidores.

\footnotetext{
${ }^{1}$ A equalização tarifária foi estabelecida pelo Decreto - Lei $1.383 / 74$. Segundo este princípio, as tarifas para consumidores de uma mesma classe deveriam ser iguais em todo o território nacional. $O$ direcionador desta medida foi a estratégia do governo federal de estender, a todos os estados da federação, os benefícios da exploração dos recursos hídricos, nesta data, concentrados nas regiões Sul e Sudeste.

2 Pela lei 5.655 de maio de 1971, ficou definido que a remuneração legal do investimento dos concessionários de serviços públicos de energia elétrica poderia oscilar no intervalo de $10 \%$ a $12 \%$ ao ano. A diferença entre a remuneração efetivamente observada e os valores limites seria registrada na CRC do concessionário, para fins de compensação dos excessos e insuficiências de remuneração, de forma a assegurar a rentabilidade dos concessionários dentro dos patamares estipulados. No período de promulgação da lei Eliseu Resende, a CRC acumulava elevado déficit, tendo as empresas do setor como credoras, devido à recorrente utilização das tarifas como instrumento de política antiinflacionária. $O$ déficit foi sanado apenas após a promulgação da lei Eliseu Resende, como medida inicial para inclusão das empresas no Plano Nacional de Desestatização. O acerto de contas envolveu cerca de US $\$ 20$ bilhões, assumidos pelo Tesouro Nacional.
} 
A base legal para o modelo do setor elétrico, ao longo da década de 90, foi gradualmente constituída com a publicação do decreto 915/93, das lei 8.987/95, 9.074/95, 9.247/96 e 9.648/98.

O decreto 915/93 permitiu a formação de consórcios entre concessionários de autoprodutores para exploração de aproveitamentos hidrelétricos.

A lei 8.987/95 regulamentou o artigo 175 da Constituição Federal, obrigou a licitação para concessão de geração, transmissão e distribuição e definiu os critérios gerais a serem aplicados nas licitações e nos contratos de concessão.

A lei 9.074/95 complementou a lei 8.987, no concernente aos serviços de energia elétrica, liberou grandes consumidores do monopólio comercial das concessionárias de distribuição, assegurou livre acesso aos sistemas de transmissão e distribuição e estabeleceu a necessidade da criação de agência reguladora para o setor.

A lei 9.247/96 criou a ANEEL. A criação da ANEEL representou marco na reforma institucional do setor, tendo em vista a tradição de regulação implícita das empresas de energia elétrica. A ANEEL foi criada como autarquia especial, com relativa autonomia decisória e financeira e independência política, o que lhe conferiu neutralidade para legislar em conflitos entre agentes do setor PIRES (2000).

Em continuidade à reestruturação legal, a lei 9.648/98 atribui maior consistência à política de reformas ao reunir medidas dispostas em atos regulatórios anteriores, bem como as proposições resultantes do trabalho encomendado à Consultoria Coopers \& Librand em 1997, no âmbito do Projeto de Reestruturação do Setor Elétrico Brasileiro (RE-SEB).

A lei estabeleceu a flexibilização dos critérios de licitação para construção de novas plantas de geração, que, ao critério do licitante, poderiam ocorrer não somente pelo critério da menor tarifa, como também pelo maior valor de outorga oferecido ou, ainda, por uma combinação destes dois critérios. A lei, com objetivo de estimular a entrada de novos agentes no setor, estendeu o regime de produção independente aos casos de privatização de empresa detentora de concessão ou autorização de geração de energia elétrica. 
Nas questões atinentes à comercialização de energia elétrica, a lei atribuiu a liberdade de contratação de suprimento aos consumidores livres, qualificados como aqueles cuja demanda contratada era igual ou superior a $3 \mathrm{MW}$ e que eram atendidos em tensão igual ou superior a $69 \mathrm{kV}$. A lei dispôs também sobre a obrigatoriedade da comercialização da energia, por meio de contratos bilaterais de longo prazo ${ }^{3}$ e curto prazo (mercado spot), estabelecidos no âmbito do Mercado Atacadista de Energia Elétrica (MAE). O preço da energia no mercado spot deveria oscilar de acordo com o risco de déficit do sistema e com a capacidade de atendimento da demanda.

A mesma lei criou a figura do Operador Nacional do Sistema Elétrico (ONS). O ONS é composto por representantes dos diversos agentes do setor e responsável pela coordenação e controle da operação das instalações de geração e transmissão de energia elétrica no Sistema Interligado Nacional (SIN).

No decorrer do longo período de reestruturação legal, o setor elétrico passou por um ciclo de crescimento do consumo não compatível com a velocidade de crescimento da oferta. Durante a década de 80 e 90, enquanto a taxa de expansão da capacidade instalada do sistema passou de $4,8 \%$ ao ano para $3,3 \%$ ao ano, a taxa de crescimento do consumo, embora também decrescente, manteve-se em patamar superior, passando de 5,9\% a.a para 4,1\% a.a. Como não houve racionamento de energia ao longo desta duas décadas, pode-se dizer que o sistema conviveu com uma situação de esgotamento da capacidade excedente. (GIAMBIAGI; PIRES; SALES; 2002)

Este descompasso entre as taxas de crescimento do consumo e dos investimentos na expansão da capacidade, combinado a um período de baixo índice de energia afluente no sistema, culminou em grave crise de abastecimento do setor elétrico brasileiro, no ano de 2001.

Segundo GIAMBIAGI; PIRES; SALES (2002), as raízes da crise de oferta de 2001 estão associadas a quatro fatores:

\footnotetext{
${ }^{3}$ Os contratos de longo prazo tinham duração mínima de dois anos e deviam cobrir, inicialmente, $85 \%$ e, mais tarde, após a crise energética de $2001,95 \%$ da necessidade de carga das distribuidoras do mercado cativo.
} 
- Esgotamento do modelo estatal, responsável pela expansão do setor desde os anos 60. O esgotamento do modelo estatal deu-se, em primeiro lugar, devido à crise fiscal do Estado e ao conseqüente declínio da capacidade de investimento da União nos níveis necessários para expansão do sistema e, em segundo lugar, pela manutenção, durante longo período, de um modelo regulatório que não incentivava a busca de eficiência e do baixo custo na geração;

- Falhas no planejamento da transição do modelo estatal para o modelo privado. O modelo proposto no âmbito do RE-SEB tinha como um de seus pilares a participação intensiva do capital privado na expansão do setor. O ingresso do capital privado no setor, entretanto, em virtude de deficiências regulatórias, não ocorreu na velocidade prevista, o que, combinado a uma retenção de investimentos estatais em função das vésperas da privatização, culminou em período de lacuna de investimentos, que comprometeu, de forma expressiva, a capacidade de armazenamento hidráulico do sistema ${ }^{4}$.

- Problemas contratuais. Segundo os autores, os contratos iniciais, celebrados entre geradores e distribuidores em 1997, herdaram as condições contratuais dos antigos contratos existentes entre estes agentes, onde $100 \%$ da demanda estavam contratados, inexistindo margem de segurança para os geradores e incentivo à contratação pelos distribuidores. Adicionalmente, o critério de cálculo da energia assegurada das plantas era baseado, na prática, em risco de déficit de energia próximo de $10 \%$, ao invés de $5 \%$, como considerado atualmente, o que tornava o valor de face dos contratos de suprimento relativamente inflados.

No modelo, os agentes de mercado eram obrigados a firmar contratos bilaterais, com prazo não menor que dois anos, para, no mínimo, $85 \%$ da sua necessidade de carga. A liberdade para contratar parte da carga no mercado spot e a possibilidade de firmar contratos bilaterais com prazo relativamente reduzidos, quando comparados à extensão do ciclo operacional de usinas de geração de energia elétrica, não incentivava a

\footnotetext{
${ }^{4} \mathrm{O}$ relatório da Comissão de Análise do Sistema Hidrotérmico de Energia Elétrica, realizado no âmbito da Câmara de Gestão da Crise Energética (GCE), em 2001, mostrou que o atraso de obras programadas e a não realização dos investimentos previstos nos planos decenais representaram um déficit de armazenamento do sistema Sudeste/ Centro-Oeste e Nordeste equivalente a $41 \%$. Este montante, se fosse somado à capacidade de armazenamento do sistema, de $32 \%$ neste período, teria levado o nível de armazenamento do sistema Sudeste/ Centro-oeste e Nordeste, para aproximadamente $73 \%$, nível que evitaria o racionamento. Além do baixo armazenamento, a crise agravou-se pelo aumento do consumo após o Plano Real e pelas condições hidrológicas desfavoráveis nas Regiões Nordeste e Sudeste, que sofreram, respectivamente, a primeira e a segunda maiores secas de suas histórias.
} 
realização de novos investimentos em geração. Na formulação do modelo vigente à época, idealizou-se que o mercado seria, por si só, capaz de sinalizar a necessidade de expansão da geração. Em outros termos, acreditou-se que o comportamento dos preços da energia no mercado spot, ao refletir o risco de déficit de energia no sistema, dispararia sinais adequados para a necessidade de novos investimentos na ampliação da capacidade instalada do sistema. O que se viu, entretanto, nos anos que antecederam o racionamento de 2001, foi um comportamento de preços de energia que não refletiu a velocidade de esgotamento dos reservatórios hídricos brasileiros Figura [2.1].

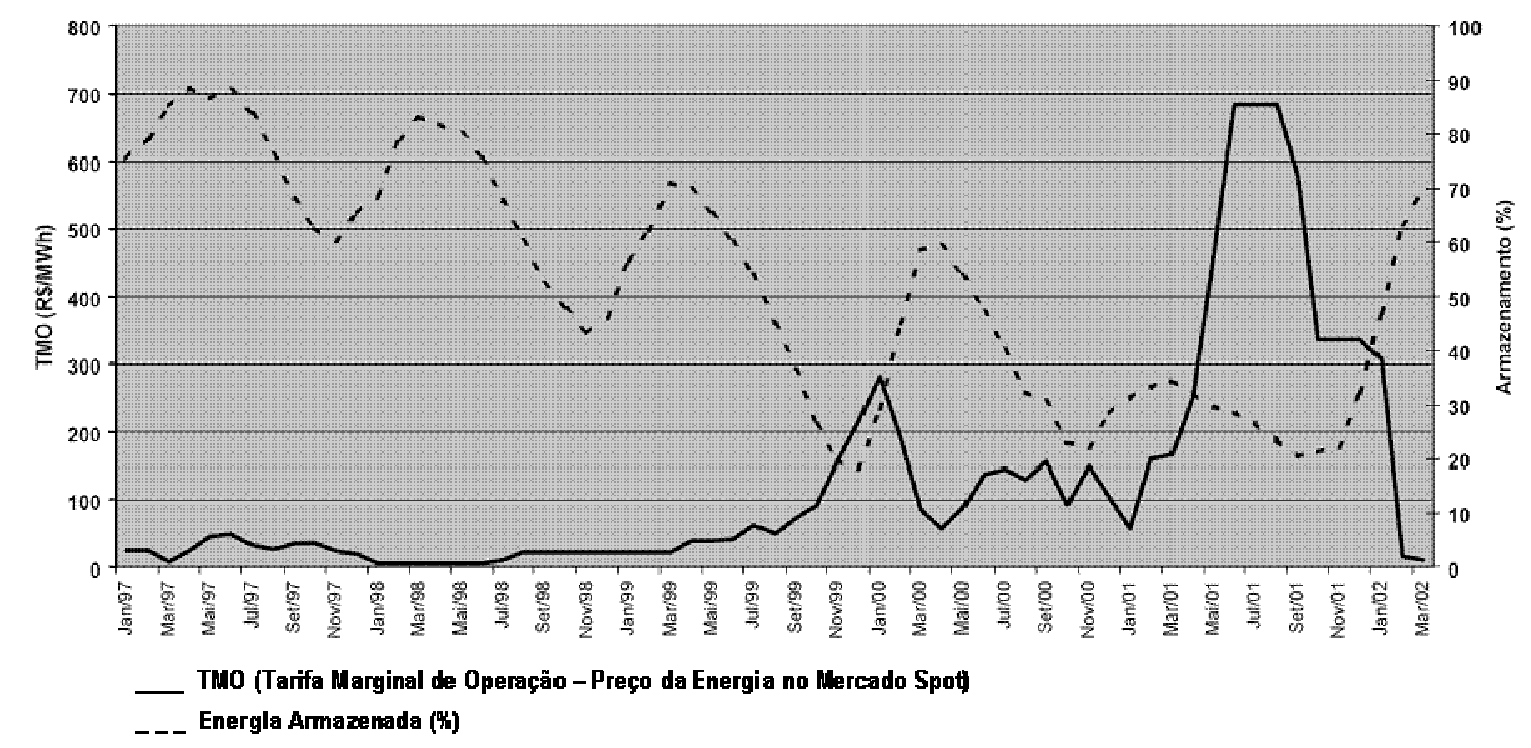

Figura 2.1 - Relação Histórica entre o Preço e o Armazenamento da Energia (Região Sudeste) Fonte: (CASTRO; 2004)

- Falta de coordenação entre os órgãos governamentais. Os autores conferem à falta de articulação entre o Ministério de Minas e Energia (MME), a ANEEL, a Agência Nacional do Petróleo (ANP) e Agência Nacional de Águas (ANA), a não identificação em tempo hábil dos sintomas de gravidade da crise e, conseqüentemente, da necessidade de aportes emergenciais em expansão da capacidade de geração e transmissão.

Diante da necessidade de soluções para a crise energética de 2001, o governo federal criou a GCE, entidade interministerial cujo objetivo central era a administração da crise energética de 2001, segundo quatro vetores de atuação: i) racionamento de até $20 \%$ no consumo de energia 
elétrica; ii) o desenvolvimento de um programa estratégico de aumento da oferta de energia elétrica; iii) o desenvolvimento de um programa emergencial de aumento da oferta de energia elétrica ("seguro-apagão") e iv) a promoção da revitalização do setor elétrico.

Em junho de 2001, a GCE criou o Comitê de Revitalização do Modelo do Setor Elétrico, com a missão de encaminhar propostas para corrigir disfuncionalidades e propor o aperfeiçoamento para o modelo. Durante a vigência da GCE, o Comitê de Revitalização liderou duas principais tarefas: a implementação do Acordo Geral do Setor Elétrico e a proposição de medidas regulatórias para aperfeiçoamento do modelo.

O Acordo Geral do Setor teve como objetivo repor o equilíbrio econômico-financeiro dos contratos de concessão de geradores e distribuidores que haviam sido afetados pela queda expressiva de receita durante o programa de amplitude nacional de redução de consumo de energia elétrica. O Acordo Geral do Setor Elétrico estabeleceu a Recomposição Tarifária Extraordinária (RTE), que resultou em aumentos de 2,9\% na tarifa dos consumidores residenciais e de 7,9\% nas tarifas dos consumidores industriais. Além dos aumentos de tarifa, o acordo estabeleceu dois preceitos importantes que contribuíram para redução da percepção do risco associado à atividade no setor. O primeiro promoveu ajustes nas regras de repasse dos custos não gerenciáveis aos consumidores, por parte das distribuidoras, e o segundo estabeleceu o aditivo nos contratos entre geradores e distribuidores, com vistas a reduzir a exposição dos agentes em períodos de racionamento do consumo de energia.

Quanto às modificações regulatórias, são apresentadas a seguir, de maneira sintética, as principais medidas apresentadas pela GCE:

- Implementação da Oferta de Preços: Em substituição ao critério do custo marginal, cujo cálculo se faz por método computacional, baseado em uma única projeção de oferta e demanda e na arbitragem do chamado custo do déficit, que, por definição, não reflete as forças de oferta e demanda impostas pelo mercado, a GCE colocou em discussão um sistema de determinação de preços baseado na oferta submetida por cada agente, que refletiria as intenções e a percepção de riscos de cada agente vendedor e comprador. O modelo baseado na submissão das ofertas de preços pelos agentes de mercado não foi instituído.

- Comercialização de Energia de Serviço Público: dada a concentração estatal no mercado de geração, de cerca de $70 \%$ no ano de 2002, a GCE estabeleceu a obrigação 
da contratação da energia gerada pelas estatais em leilões públicos exclusivamente organizados para este fim. Estes leilões foram chamados de Leilão de Energia Velha e os preços aí praticados refletiriam a estrutura de custos das empresas detentoras de usinas já depreciadas, em geral bastante inferiores àqueles das novas usinas. Esta medida visou assegurar o fluxo de investimento privado em geração, uma vez que a competição direta com as empresas públicas, com ativos já depreciados, inibiria a participação privada.

- Estímulo à Contratação Bilateral: A GCE, visando reduzir a exposição dos geradores privados à volatilidade de preços do mercado spot, aumentou a obrigatoriedade de contratação de longo prazo dos distribuidores, de $85 \%$, para $95 \%$ das suas necessidades de carga.

- Mudança na Regra do Valor Normativo (VN): o valor normativo configurava o preço limite de compra de energia, até o qual as distribuidoras tinham garantido o direito de repasse de custos para a tarifa dos seus consumidores. Como os empreendimentos não hidrelétricos têm custos mais elevados e o modelo inicial estabelecia valores normativos distintos para cada tipo de geração, os consumidores ficavam expostos a diferentes tarifas, a depender da estratégia de compra da energia da sua distribuidora. A GCE propôs a definição de um único valor de VN para todo o sistema interligado. Na nova proposta, a política de incentivos à diversificação da matriz energética seria dirigida por meio de fundos, cujos recursos seriam utilizados para suprir a diferença entre o custo de geração e o valor normativo único.

- Realinhamento Tarifário e Abertura das Parcelas das Tarifas de Distribuição: A decomposição da tarifa de energia em serviços de transmissão / distribuição (fio), serviços de comercialização (tarifação e cobrança) e o preço da energia (geração). A abertura permitiria comparação mais apurada entre o custo da energia na condição de consumidor livre e consumidor cativo, incentivando a migração dos grandes consumidores da segunda para a primeira situação. A prática da decomposição tarifária e a conseqüente migração dos grandes consumidores contribuiriam ainda para o rebalanceamento tarifário, eliminando a existência de subsídios entre classes distintas de consumidores.

- Desverticalização e Limites para Autocontratação: A desverticalização das atividades competitivas (geração e comercialização) daquelas que caracterizam monopólio natural (transmissão e distribuição). 
A partir de 2003, o governo federal extinguiu a GCE e definiu novo marco na reestruturação do setor elétrico brasileiro. As disposições do modelo vigente mantêm os preceitos do extenso período de reformas, bem como das propostas lançadas no âmbito da GCE, mas incorporam sensíveis alterações na base institucional do setor e nas regras para comercialização de energia. O modelo brasileiro vigente foi instituído pelas leis 10.847 e 10.848 e será discutido adiante, de forma pormenorizada, no capítulo 3.

A seguir, ainda no capítulo 2, em complemento ao histórico de reformas no Brasil, serão abordadas as experiências de reestruturação do setor elétrico dos Estados Unidos, Reino Unido e Chile, três países cujas reformas são tratadas como paradigma de reestruturação do setor elétrico. 


\subsection{EXPERIÊNCIA INTERNACIONAL}

\subsubsection{O Caso dos Estados Unidos ${ }^{5}$}

A reestruturação do setor elétrico norte-americano é caracterizada por um processo lento e gradual de introdução das reformas oriundas, principalmente, de dois marcos regulatórios: o Public Utilities Regulatory Policy Act (Purpa Act), de 1978, e o Energy Policy Act, de 1992.

O Purpa Act foi aprovado pelo Congresso Norte-Americano em 1978 e, ainda que tivesse como objetivo primeiro a expansão da oferta de energia proveniente de fontes renováveis, visava reduzir a capacidade instalada das empresas elétricas ${ }^{6}$, reduzir o valor das tarifas de eletricidade e estimular a entrada de produtores independentes de energia no mercado. À época da criação do Purpa Act, as tarifas de energia encontravam-se em patamares elevados em função do critério de determinação da tarifa de energia que considerava a remuneração pelo custo do serviço, permitindo que fossem repassados aos consumidores os aumentos nos custos dos insumos e serviços, estimulando as empresas do setor ao sobre-investimento e contrapondo-se à busca por ganhos de produtividade.

Como mecanismo paliativo para contenção do processo progressivo de evolução de tarifas, o Purpa Act instituiu o princípio do custo evitado, segundo o qual só seriam autorizados investimentos em novas usinas de geração por parte dos concessionários, se o custo de construção fosse inferior ao custo de aquisição de energia de produtores independentes, denominados Qualifying Facilities ${ }^{7}$, que, pelo ato, foram autorizados a comercializar energia com as concessionárias verticalmente integradas.

\footnotetext{
${ }^{5}$ Com base em PIRES (1999).

${ }^{6}$ A aprovação do Purpa Act sucedeu um período de intensificação de investimentos em usinas de geração de fonte nuclear. Os investimentos em energia nuclear, por sua vez, foram suscitados por expectativas de forte crescimento da demanda por energia elétrica combinadas a uma projeção de aumento dos preços do petróleo, que em ocorrendo, tornariam a opção pela fonte nuclear economicamente vantajosa. A crise econômica verificada no período fez com que a demanda realizada ficasse posicionada em patamar inferior ao esperado e, consequentemente, gerasse um excesso generalizado de oferta energética no país.

${ }^{7}$ As Qualifying Facilities eram caracterizadas como tal por critério de capacidade e tecnologia. No entanto, em vista do critério de determinação tarifária desestimular ganhos de produtividade e a economicidade de novos investimentos, apenas empresas detentoras de um único ativo de geração e que não possuíam ativos de transmissão ou distribuição, como por exemplo, pequenos produtores de fontes renováveis, produtores independentes, autoprodutores e principalmente co-geradores, tornaram-se Qualifying Facilities. Os Qualifying Facilities tinham garantida a compra de toda sua
} 
Um dos principais legados do Purpa Act foi a diversificação e expansão do mercado de geração, com a entrada dos produtores independentes de energia em ambiente restrito, até então, às tradicionais concessionárias integradas. Em contrapartida, segundo PIRES (1999), o aspecto negativo da implantação do Purpa Act foi o reforço à manutenção do paradoxal fenômeno de sobre-capacidade combinado ao aumento das tarifas, em função de três fatores: i) à forma como muitos estados aplicaram o conceito de custo evitado, o que incentivou a entrada não econômica de várias plantas; ii) ao fato do Purpa Act ter mantido inalterada a política de determinação das tarifas pelo critério da remuneração pelo custo do serviço e, por fim, iii) pela inexistência de mecanismos de garantia de acesso às redes de transmissão e distribuição, fato não impeditivo ao comportamento discriminatório das concessionárias integradas e potencialmente prejudicial à promoção da concorrência no setor.

Em 1992, o Energy Policy Act estabeleceu dois preceitos que convergiram para a solução das deficiências verificadas na implantação do Purpa Act, no sentido da promoção da competição no setor e flexibilização das transações de compra e venda de energia: a garantia de acesso não discriminatório aos sistemas de transmissão e a criação de um amplo mercado atacadista de energia. As principais disposições do Energy Policy Act são as seguintes:

- criação dos Exempt Wholesale Generators (EWG's), cujas características básicas são as seguintes: possuem apenas ativos de geração, não têm obrigações de investimento nem limitações geográficas de atuação como as concessionárias integradas, devem comercializar energia apenas no mercado por atacado e não têm qualquer garantia de venda da energia disponibilizada;

- instituição de autoridade legal para a Federal Energy Regulatory Commission $(\text { FERC })^{8}$ para: garantia de acesso não discriminatório às redes de transmissão, concessão do status EWG e legislação em matérias eventualmente divergentes ou não abordadas nas disposições do Energy Policy Act;

- incentivos a programas de conservação de energia e de gerenciamento de demanda;

energia pelo custo marginal de expansão do sistema ou pelo custo evitado das concessionárias verticalmente integradas. A garantia de compra da energia produzida, atrelada ao baixo custo de produção das novas tecnologias de geração, provocaram a entrada excessiva, sem compromisso com o balanço energético, de plantas de geração.

${ }^{8}$ A FERC foi instituída em 1977 e tem como atribuição a regulação dos oleodutos e gasodutos interestaduais, bem como das vendas por atacado de eletricidade e dos serviços de transmissão de energia elétrica. Historicamente, o setor elétrico norte-americano é regulado na esfera federal pela FERC e na esfera estadual pelas Public Utilities Commissions - PUC's. 
- estímulo à adoção de novo regime tarifário, que contemple o repasse de ganhos de produtividade aos consumidores cativos;

- definição de critérios de transição para tratamento dos stranded costs ${ }^{9}$.

Como resposta às disposições regulatórias do Energy Policy Act, verificou-se um aumento da capacidade instalada associado à criação da figura das EWG's, que se proliferaram, diante da possibilidade de ganhos de produtividade advindos da utilização de novas tecnologias de geração $^{10} \mathrm{e}$, principalmente, pela opção de concessionárias integradas pela constituição de empresas de geração desverticalizadas, com objetivo de tirar proveito da flexibilidade regulatória de que gozavam as EWG's.

De outro lado, em contraposição às disposições do ato regulatório e à expansão do parque gerador, o livre acesso à rede de transmissão dependia da análise da solicitação pela FERC caso a caso, em processos morosos que, conseqüentemente, causavam insatisfação dos novos entrantes.

Neste sentido, adicionalmente às proposições do Energy Policy Act, em 1996 e 1997, a FERC, visando assegurar a competição no setor e estimular as transações no mercado atacadista, lançou duas diretrizes ${ }^{11}$ complementares cujas medidas, de forma geral, trataram do seguinte:

- estímulo à constituição de operadores independentes do sistema, pessoa jurídica com a função de operar o conjunto das redes do sistema de transmissão;

- aplicação de critérios de tarifação transparentes para os serviços de acesso à rede de transmissão e distribuição;

\footnotetext{
${ }^{9}$ Custos relacionados aos investimentos realizados pelas concessionárias para atendimento da totalidade do mercado, em período de regime de monopólio natural, que, em um ambiente competitivo, tornam-se dificilmente recuperáveis. Segundo PIRES (1999), as concessionárias eram estimuladas nos contratos de concessão a antecipar investimentos. Daí o aparecimento dos stranded costs em larga escala.

${ }^{10}$ Trata-se especificamente das vantagens da tecnologia de geração de ciclo combinado alimentadas com gás natural (CGCC) em relação às fontes tradicionais - carvão e nuclear. Segundo BAYLES (1994) apud PIRES (1999), as inovações tecnológicas na geração alteraram o tamanho, o tempo e o custo de construção das usinas. Nas novas plantas a gás, estes itens apresentavam, respectivamente, 50 a 150MW, o prazo de um ano e o custo de US\$30-50/MWh, enquanto que, nas tecnologias tradicionais, esses mesmos itens eram de 500MW, 10 anos e US\$ 40-70/MWh (carvão) e US\$ 90-150/MWh (nuclear).

${ }^{11}$ As medidas lançadas pela FERC têm caráter diretivo. Não existe autoridade legal para ação imperativa da FERC em temas como funcionamento do mercado atacadista, ou liberação do mercado cativo, nem tampouco, no imbróglio dos stranded costs. A legislação nestes temas está a cargo das PUC's.
} 
- $\quad$ sugestão para a formação de Bolsas de Energia - Power Exchange (PX) - , ambiente no qual se realizariam transações de curto prazo de compra e venda de energia entre geradores e consumidores livres. A criação da Bolsa de Energia teve por objetivo formar preços de referência para energia, como forma de auxiliar e incentivar a efetivação de contratos bilaterais de suprimento e como mecanismo de indução de competição no mercado cativo, propiciando o surgimento de agentes intermediários nas transações junto aos consumidores finais;

- $\quad$ sugestão para cobertura dos stranded costs, por meio de atos autorizativos, no âmbito das PUC's;

- $\quad$ sugestão de abertura do mercado cativo de energia elétrica para a competição.

Nos últimos anos, as reformas postuladas no Energy Policy Act e em suas medidas complementares vêm sendo implementadas, estado a estado, em velocidade e teor distintos.

O estado pioneiro na implementação da reforma do setor elétrico foi o estado da Califórnia. Conforme as disposições do ato regulatório, os pilares do modelo californiano são o Operador Independente do Sistema - Independent System Operator (ISO), entidade responsável pela segurança do sistema, pela operação das linhas de transmissão e pelo gerenciamento das transações no mercado de curto prazo (spot), e o PX, ambiente onde as transações de compra e venda de energia aconteceriam diariamente. O preço no PX era determinado em intervalos de uma hora pela identificação do ponto de intersecção de curvas de oferta e demanda, formadas, respectivamente, pelos preços de suprimento propostos pelos geradores e pelos preços de compra submetidos pelos comercializadores e distribuidores (U.S DEPARTMENT OF ENERGY; 2003).

Conforme descrevem ARITZIA; WATTS (2002), durante o período compreendido entre os anos de 2000 e 2001, o sistema elétrico da Califórnia entrou em forte crise devido a uma combinação de fatores circunstanciais, que provocaram aumentos expressivos do preço da energia e de medidas regulatórias inadequadas, que levaram o sistema ao colapso. Entre os fatores circunstanciais estão: i) um aumento significativo na demanda (crescimento de 12,7\% em junho de 2000) devido às altas temperaturas de um dos verões mais quentes da história do estado da Califórnia; ii) crescimento inesperado dos preços de gás natural (mais de 10 vezes entre 1999 e 2000) e iii) uma considerável redução da energia importada devido aos baixos volumes dos reservatórios dos estados localizados ao nordeste do país. Adicionalmente, 
acumulava-se no estado um déficit crescente de investimentos em geração, em função das incertezas de um longo período de reformas iniciados em 1994 e apenas concluído em 1998. Entre as medidas regulatórias, os autores destacam duas:

- como mecanismo para maximizar a competição, não era permitido aos varejistas estabelecer contratos de longo prazo de compra e venda de energia, estes eram obrigados a adquirir toda a energia requerida via transações no mercado diário de energia;

- congelamento das tarifas de venda de energia no mercado de varejo durante quatro anos. O congelamento que, quando de sua instituição objetivou a recuperação dos stranded costs por parte das concessionárias de distribuição, no período de aumento expressivo da tarifa de suprimento, fez com que as concessionárias de distribuição trabalhassem com margens extremamente reduzidas e até negativas em períodos de pico da tarifa de suprimento. Conforme citam os autores, a manutenção da política de congelamento dos preços no mercado de varejo durante a crise, combinada a um aumento das tarifas de suprimento ${ }^{12}$ e à impossibilidade de se estabelecer contratos de longo prazo, que permitissem aos distribuidores protegerem-se das oscilações do preço de energia, deixou os três distribuidores existentes no mercado em posição financeira bastante fragilizada.

Assim como ocorrido na Califórnia, o Texas e a Pennsylvania foram estados pioneiros na reestruturação do sistema elétrico, passam pela transição para um mercado elétrico baseado na competição e são apontados também como referências da evolução do processo de implantação das reformas no setor elétrico norte-americano.

No Texas, o processo de abertura total do mercado ocorreu no início do ano de 2002 para os consumidores atendidos no âmbito do Eletric Reliability Council of Texas (ERCOT). Como parte das ações de reestruturação, o governo exigiu a venda por parte das concessionárias verticalizadas detentoras de ativos de geração, de $15 \%$ de sua capacidade instalada até o prazo

12 O efeito foi maximizado por ações de manipulação de preços de suprimento por parte de grandes empresas de geração. Em maio de 2002, a FERC tornou público memorandos internos da empresa Enron que indicavam ações de manipulação do mercado de energia da Califórnia, por meio dos seguintes vetores: (i) incitação de falsa congestão em linhas de transmissão; (ii) transferência da energia produzida na Califórnia, em operações de compra e venda interestaduais, como forma de driblar o controle de preços no mercado californiano e (iii) ações para agravar períodos de racionamento da oferta, visando aumentar o preço da energia no mercado (THE WASHINGTON POST, 2002). 
máximo de 60 dias antes da abertura total do mercado. No modelo texano, os consumidores com carga superior a 1 MW têm a opção de escolher o agente supridor no mercado competitivo. Para os consumidores com carga inferior a este valor, a energia é fornecida pelas tarifas praticadas no mercado, exclusivamente, pelas concessionárias distribuidoras do mercado cativo (U.S DEPARTMENT OF ENERGY; 2003).

A reestruturação do setor elétrico da Pennsylvania é um dos raros casos de abertura total do mercado cativo de energia. O mercado de energia elétrica deste estado é controlado pela Regional Transmission Organization (RTO) que fornece previsões de preço horosazonal de energia para o horizonte de um dia, assim como a programação e o balanço energético para as regiões da Pennsylvania, New Jersey, Maryland e Delaware. Na Pennsylvania, através de um rigoroso programa educativo, decompôs-se a conta de energia elétrica em parcelas provenientes da remuneração pelos serviços de geração, transmissão e distribuição e, por meio da concessão de benefícios sobre a parcela referente à geração na conta de energia elétrica, os consumidores residenciais foram incentivados a escolher o supridor de energia segundo uma perspectiva competitiva de mercado. Desde início das reformas, o preço da energia na Pennsylvania segue trajetória de queda, mesmo diante do crescimento expressivo do preço do gás natural no período (U.S.DEPARTMENT OF ENERGY; 2003).

\subsubsection{O Caso do Reino Unido ${ }^{13}$}

O processo de reforma do mercado de energia elétrica do Reino Unido originou-se do Electricity Act de 1989, que combinou ações voltadas para a privatização com desenvolvimento de um arcabouço regulatório pautado na promoção da desverticalização das atividades de geração, transmissão e distribuição, na criação da atividade de comercialização de energia, em mecanismos para criação de um ambiente competitivo na geração e comercialização e em preceitos regulatórios nos segmentos de monopólio natural (transmissão e distribuição).

O processo de privatização teve início pela venda dos ativos de distribuição, em 1990, e posteriormente, em 1991, pela venda das centrais de geração. Após a compra dos ativos

\footnotetext{
${ }^{13}$ Com base em PIRES (1999).
} 
estatais, os novos agentes do setor foram obrigados a assinar contratos de prestação de serviço com vigência de três anos, com vistas a evitar quaisquer sobressaltos no processo de transição para o modelo de base privada (ALENCAR; 1998).

A reestruturação do setor elétrico apresentou as seguintes características básicas:

- Fragmentação dos ativos de geração da Central Electricity Generating Board $(\mathrm{CEGB})^{14}$ em três novas empresas: National Power (NP), Power Gen (PG) e Nuclear Electric (NE). As duas primeiras foram privatizadas no ano de 1991 e a terceira permaneceu estatal até 1996, quando foi fundida com a Scottish Nuclear, dando origem a duas novas empresas: a British Energy e a Magnox Eletric, a primeira privatizada no mesmo ano e a segunda mantida estatal;

- Restrições ao self-dealing ${ }^{15}$, como forma de incentivar a concorrência na geração. As distribuidoras poderiam deter ativos de geração, ou contratar energia de geradoras vinculadas, em quantidade suficiente para atendimento de, no máximo, 15\% de seus mercados;

- Desverticalização das atividades de geração e transmissão, com criação de empresa específica para a transmissão, a National Grid Company (NGC), que absorveu os ativos de alta-tensão da CEGB;

- Criação do segmento de comercialização de energia para o consumidor final. Segundo cronograma de abertura do mercado estabelecido pelas reformas: já em 1990, todos os consumidores com carga máxima superior a $1 \mathrm{MW}$ poderiam aderir ao mercado livre de energia; a partir de 1994, este limite seria reduzido para 100kW e, a partir de 1998, qualquer consumidor teria a possibilidade de escolha de seu fornecedor. Para que os objetivos de liberalização fossem atingidos, o regulador estabeleceu a obrigatoriedade de livre acesso às redes de distribuição de energia elétrica;

- Criação do mercado atacadista de energia. O órgão responsável pela organização do ambiente de comercialização definiria o preço de energia no mercado spot, pelo cruzamento das ofertas de preço declaradas pelos geradores com capacidade de carga superior a 10MW, para cada meia hora do dia seguinte, com a curva de demanda, obtida pelo tratamento de informações sobre o comportamento passado de distribuidores, comercializadores e consumidores livres. Uma vez balanceada a

\footnotetext{
${ }^{14}$ A CEGB foi criada em 1956 e, até 1989, respondeu pela geração e transmissão de cerca de 95\% da energia comercializada no Reino Unido.

${ }^{15}$ Termo utilizado no mercado de energia elétrica para designar a comercialização de energia entre empresas do mesmo grupo econômico.
} 
configuração de oferta e demanda do sistema, o preço marginal do sistema é o valor correspondente à maior oferta de preço validada, ou seja, a oferta submetida pela planta cuja capacidade completa a quantidade demandada, segundo uma hierarquia de preços crescentes. Uma vez definido o preço marginal do sistema, este é o preço que remunera todas as centrais geradoras, independente do valor ofertado anteriormente;

- Possibilidade de estabelecimento de contratos bilaterais de compra e venda de energia, visando à proteção aos riscos de oscilação de preços no pool. No sistema inglês, as diferenças contratuais são liquidadas no mercado atacadista ao preço spot (contract for diferences $)^{16}$. Dois tipos de contratos são os mais usuais: dupla opção e simples opção contra o pool. No primeiro caso, nas situações em que o preço no pool é superior ao preço de contrato, o gerador compromete-se a ressarcir o distribuidor / grande consumidor a diferença. Nas ocasiões inversas, isto é, quando o preço do pool é inferior ao do contrato, o distribuidor / grande consumidor compromete-se a reembolsar a diferença ao gerador. No segundo tipo de contrato, apenas o gerador fica com o compromisso, assumindo o risco de arcar com a diferença no evento de os preços no pool serem superiores aos do contrato (ALENCAR, 1998).

A base para inserção da competição no mercado inglês seria o adequado funcionamento do pool, promovendo a redução de barreiras para entrada de novos agentes neste segmento, concentrando, para tanto, a maior parte da energia comercializada e sinalizando preços referenciais para contratação de energia no longo prazo. Segundo PIRES (1999), os motivos que inibiram o funcionamento do pool, que, nos dez primeiros anos de funcionamento, registrou um volume de transações correspondente a apenas 10\% do total de energia comercializada no mercado, foram a dificuldade de modelagem do preço spot de energia, a possibilidade de estabelecimento de contratos bilaterais ${ }^{17}$ e a elaboração de contratos iniciais para suprimento das indústrias de carvão e energia nuclear ${ }^{18}$.

\footnotetext{
${ }^{16}$ A prerrogativa de liquidação das diferenças ao preço spot, presente nos contratos de compra e venda de energia de longo prazo firmados no modelo inglês está, também, incorporada ao modelo regulatório brasileiro vigente, que será discutido no capítulo 3.

${ }_{17}$ Os novos entrantes no segmento de geração garantem a compra da totalidade de sua energia via contratação bilateral, o que torna a oferta de energia no pool, quase que exclusivamente, proveniente das empresas National Power e Power Gen. O fato dos demais geradores evitarem o pool, pode ser lido como causa e efeito, da manipulação, segundo práticas anticompetitivas, do mercado spot pela National Power e Power Gen.

${ }^{18}$ Exigência de estabelecimento de contratos iniciais, com prazo de três anos, visando proteger indústrias de carvão e nuclear. Estes contratos estabeleciam as seguintes obrigações: i) compra de carvão da British Coal pela NP e PG; ii) aquisição de energia nuclear pelas distribuidoras do mercado cativo; iii) obrigação de aquisição de toda energia gerada pela NP e pela PG, proveniente da fonte
} 
No início de 2001, o regulador do sistema elétrico britânico criou uma nova forma de comercialização de energia, abandonando o sistema atacadista vigente desde início da implantação das reformas. As transações no novo modelo de mercado ocorreriam no ambiente de transações denominado New Electricity Trading Arrangement (NETA). A principal mudança em relação ao antigo pool foi a substituição da sistemática de determinação do valor da tarifa de energia, que passou a considerar o preço efetivo da oferta submetida por cada um dos geradores.

$\mathrm{Na}$ nova sistemática, o sistema elétrico é dirigido pelas forças de oferta e demanda, diferentemente da configuração anterior do pool, onde a NGC tinha como parte de suas responsabilidades a previsão da demanda no mercado de curto prazo, a garantia da suficiência de suprimento, bem como a determinação do preço marginal do sistema. Os direcionadores da mudança da sistemática de funcionamento do pool foram, primeiro, a insatisfação dos consumidores com o comportamento dos preços da energia que, mesmo em períodos de queda acentuada dos custos de geração, caíram muito pouco e, segundo, com as ações de manipulação sobre os preços, que se evidenciavam nas transações efetuadas no mercado. A antiga sistemática, em função de o preço transacionado ser fixado com base na maior oferta de preço de energia, tornava o ambiente de negociação suscetível à manipulação por parte dos geradores, dado que estes só teriam a ganhar elevando suas ofertas e influenciando o estabelecimento do preço marginal de energia em alto patamar. A expectativa era que a nova configuração do pool reduzisse a probabilidade de manipulação e concentração de mercado. O NETA também contemplou, em sua criação, a permissão para operações de derivativos e futuros, propiciando nova maneira de proteção aos agentes do pool contra flutuações do preço de energia.

O método de tarifação dos serviços de monopólio natural nos segmentos de transmissão e distribuição passou, após as reformas, a ser arbitrado pelo regime Price Cap. O método de tarifação pelo Price Cap substitui o critério de determinação pela remuneração fixa sobre o custo do serviço que, conforme já discutido anteriormente, não incentiva ganhos de

carbonífera, por parte das distribuidoras do mercado cativo, com objetivo de não criar desvantagem competitiva para o duopólio frente aos eventuais novos entrantes. Após o término dos três anos, tanto as distribuidoras, dentro do limite de verticalização permitido, como a NP e PG deram início a construção de usinas geradoras de ciclo combinado alimentadas a gás natural (tecnologia de maior eficiência produtiva). 
produtividade e estimula o sobre-investimento por parte dos agentes distribuidores e transmissores. Além do estímulo aos ganhos de produtividade na prestação do serviço e à possibilidade de repassá-los ao consumidor final, o método Price Cap tem o benefício de redução da exposição do regulador aos riscos de assimetria de informações e da eliminação dos custos associados a controles e processos de fiscalização, necessários para determinação do valor da tarifa pelo critério de remuneração pelo custo do serviço, onde a determinação da tarifa exige a auditoria rotineira por parte do regulador sobre os custos incorridos pela entidade prestadora dos serviços.

O método Price Cap, na sua concepção básica, contempla a definição de um preço-teto para o serviço prestado, indexado a determinado índice de preços ao consumidor, menos um fator $\mathrm{X}$, equivalente ao repasse de ganhos de produtividade para um período prefixado de anos. A aplicação deste mecanismo no mercado elétrico inglês contempla, adicionalmente, um fator Y de repasse de custos para os consumidores, associado à parcela de custos considerados não gerenciáveis (por exemplo, impostos e preço de insumos, bens e serviços que compõe a cadeia de fornecimento), resultando na seguinte equação para determinação do reajuste tarifário: IP-X+Y, onde IP - índice de preços ao consumidor; $\mathrm{X}$ - fator de produtividade e $\mathrm{Y}$ - fator de repasse de custos não gerenciáveis. A adoção do fator Y gerou críticas, sob o ponto de vista do consumidor final, uma vez que a aplicação de tal fator estaria impedindo o repasse proporcional da redução de custos de insumos e serviços de geração às tarifas de energia.

O método Price Cap, em contraponto ao método da taxa de retorno pelo custo do serviço, tem como viés a tendência ao sub-investimento em incremento de qualidade, uma vez que tais imobilizações implicariam em elevações do nível de custos das empresas sem a contrapartida tarifária no curto prazo, fazendo com que o retorno para tais investimentos só se realizassem pela via de ganhos de produtividade no longo prazo. Para contorno de tal situação, o regulador inglês criou dois mecanismos regulatórios complementares ao Price Cap. $\mathrm{O}$ primeiro, denominado Padrão Garantido (Guaranteed Standards), obriga os agentes comercializadores ao pagamento de compensação financeira aos consumidores, para o caso em que não forem cumpridos os preceitos do serviço padrão definido pelo regulador. $\mathrm{O}$ segundo, traduzido para o português como Competição por Comparação (Yardstick Competition), estabelece a comparação entre os padrões de desempenho das empresas de mesmo segmento - benchmarking, por meio da divulgação periódica aos consumidores de um ranking de performance. 


\subsubsection{O Caso do Chile ${ }^{19}$}

O mercado elétrico chileno foi também um dos primeiros mercados a iniciar os movimentos de reestruturação, no ano de 1982. A base do modelo elétrico chileno é o Centro de Despacho Económico de Carga (CDEC), que tem, ao seu cargo, o controle do sistema de transmissão, a determinação do despacho centralizado e o cálculo do preço horosazonal da energia no mercado spot.

O mercado chileno tem peculiaridades quanto a formação dos preços de energia elétrica. Os consumidores com carga superior a $500 \mathrm{~kW}$, chamados consumidores livres, negociam seus preços diretamente com geradores ou distribuidores. Os consumidores regulados pagam uma tarifa composta por uma parcela associada à remuneração pelos serviços de geração, mais uma parcela variável correspondente à remuneração pelos serviços de distribuição.

A parcela de geração, denominada preço de nó, é definida semestralmente pelo regulador e forma-se a partir de duas componentes, uma referente à remuneração pela energia gerada e outra à remuneração pela potência disponibilizada no sistema. A primeira é calculada com base na média das projeções dos custos do sistema para um horizonte de fornecimento de quatro anos e a segunda é determinada com base no custo de investimento para expansão do sistema, tomando como referência a planta existente no sistema cuja tecnologia apresente maior eficiência. Até maio de 2005, o preço de nó, definido semestralmente pelo regulador, foi a base para o cálculo do preço da energia que remunera os agentes de geração.

Contudo, em maio de 2005, o governo chileno alterou a sistemática de determinação da tarifa ao instituir a lei 20.018, que obriga as concessionárias de distribuição de energia elétrica a manter disponível $100 \%$ da energia necessária para suprimento de seus mercados, em um horizonte de três anos, considerando sua capacidade própria de geração e contratos de suprimento de longo prazo, firmados com, ao menos, três anos de antecedência à data de início de suprimento.

\footnotetext{
${ }^{19}$ Com base em ARITZIA; WATTS (2002).
} 
Conforme dispõe a lei, os contratos de suprimento devem ser firmados com agentes de geração, selecionados por meio de leilão público regulado, por critério de menor preço. Os contratos firmados nos leilões têm duração de até 15 anos e preços fixos, indexados à evolução de determinado índice de inflação. Os leilões de energia devem, gradualmente, contribuir para o aumento da percepção de segurança sobre investimentos em geração, à medida que eliminam gradualmente a incerteza associada às revisões semestrais do preço de energia, impostas pelo regulador, na sistemática anterior.

O mercado de energia chileno contempla ainda o mercado spot, ambiente de transações de compra e venda entre geradores, onde o preço de energia é definido em intervalos de uma hora pelo operador do sistema e deve estar baseado no custo auditado da planta cuja oferta supre o pico de demanda do sistema.

O sistema elétrico chileno opera com um determinado grau de sobre-oferta, como medida para manutenção da segurança do sistema. A legislação estabelece, para determinação do nível de sobre-oferta, o parâmetro denominado Margen de Reserva Teórico (MRT), fixado pelos reguladores. Ao final de cada ano, o MRT é aplicado para balanço anual de energia gerada pelo sistema, efetuado pelo CDEC, onde são identificados os déficits e excedentes de cada agente gerador frente aos compromissos por estes firmados, originando, se necessário, a transferência de pagamentos por energia entre geradores do sistema.

Ainda, como medida para gerenciamento de períodos de insuficiência de oferta, o regulador estabeleceu o mecanismo de compensação tarifária, segundo o qual o gerador deve compensar os consumidores regulados, por meio das distribuidoras do mercado cativo, quando não cumprir as obrigações de suprimento firmadas. O preço do $\mathrm{kWh}$ não suprido é fixado pelo regulador e representa uma estimativa do custo incorrido pelo consumidor pelo não recebimento da energia. O estabelecimento da tarifa pelo não suprimento tem dois objetivos básicos: evitar que os geradores estabeleçam contratos cujos montantes superem sua capacidade de fornecimento e expor o consumidor ao custo global efetivo da energia, considerando as situações de suprimento insuficiente.

Para melhor entendimento das transações no mercado elétrico chileno, estão listadas abaixo as principais ações comerciais de cada agente:

- Geradores 
- Compram e vendem energia junto aos demais geradores no mercado spot;

- Vendem energia aos consumidores livres (com carga superior a 500kW) por preços negociados livremente em contratos bilaterais;

- Vendem energia aos distribuidores, que operam no mercado cativo;

- Pagam tarifa ao operador do sistema de transmissão, proporcional à energia injetada no sistema;

- Pagam tarifa ao operador do sistema de transmissão, proporcional à quantidade de energia retirada do sistema para atendimento dos consumidores livres;

- Pagam tarifa ao operador do sistema de transmissão, proporcional à quantidade de energia retirada do sistema para atendimento dos consumidores regulados.

- Transmissores - Proprietários dos Ativos de Transmissão

- Cobram pelo uso do sistema, de acordo com as quantidades de energia disponibilizada e retirada do sistema.

- Distribuidores

- Pagam tarifa aos geradores pela energia disponibilizada na rede de distribuição;

- Recebem tarifa dos clientes regulados pelo uso do sistema de distribuição;

- Recebem tarifa dos consumidores livres (clientes diretos dos geradores) pelo uso do sistema de distribuição;

- Transferem aos clientes regulados a tarifação correspondente ao preço de nó, devido aos geradores.

Atualmente, o sistema elétrico chileno tem capacidade instalada de aproximadamente 12.000 MW, transportadas via dois sistemas interligados de transmissão. A matriz energética do país é composta em proporção aproximada de $50 \%$ pela fonte hidrelétrica, $33 \%$ pela fonte térmica a gás natural e o restante pela fonte térmica a carvão (BARROSO; BLANCO; RUDNICK;2005). 


\section{NOVO MODELO DO SETOR ELÉTRICO BRASILEIRO}

\subsection{ESTRUTURA}

O governo brasileiro, através das leis 10.847 e 10.848, aprovadas em março de 2004, estabeleceu as diretrizes para o funcionamento do novo modelo do setor elétrico brasileiro. Os objetivos da criação do novo modelo, segundo o Ministério das Minas e Energia (MME), são assegurar a eficiência na operação e prestação do serviço aos consumidores, garantir a modicidade tarifária e criar um ambiente regulatório estável que seja estímulo à concorrência, mostre-se atrativo ao ingresso de novos investimentos privados no setor e que mantenha orientação para as funções de planejamento setorial de longo, médio e curto prazos.

A nova estrutura institucional do modelo elétrico brasileiro está orientada para as funções de planejamento setorial, segurança de suprimento, regulação e fiscalização. Conforme MME (2003), a nova estrutura conta, sem hierarquia, com as entidades abaixo - Figura [3.1]:

- Conselho Nacional de Política Energética (CNPE) - órgão de assessoria da presidência da república, multi-ministerial, presidido pelo ministro de minas e energia, cujo objetivo é a formulação de políticas nacionais e diretrizes de energia, visando, dentre outros, o aproveitamento racional dos recursos energéticos do país, a revisão periódica da matriz energética e a definição de diretrizes para programas setoriais específicos.

- Ministério das Minas e Energia (MME) - ministério cuja função é a formulação e implementação, no âmbito federal, da política energética nacional.

- Empresa de Pesquisa Energética (EPE) - empresa pública federal vinculada ao MME, que tem como missão atuar nos estudos voltados para o planejamento energético nacional, associados às projeções da composição da matriz energética nacional, do balanço energético nacional, do aproveitamento ótimo dos recursos hídricos, do licenciamento ambiental e, por fim, do planejamento da expansão da geração e transmissão de energia elétrica de curto, médio e longo prazos. 
- Comitê de Monitoramento do Setor Elétrico (CMSE) - grupo instituído sob coordenação do MME, que tem como finalidade assegurar a continuidade e a segurança do suprimento de energia no país.

- Agência Nacional de Energia Elétrica (ANEEL) - autarquia, também vinculada ao MME, que tem por objetivo a fiscalização e regulação das funções de geração, transmissão, comercialização e distribuição de energia elétrica em todo o território nacional.

- Operador Nacional do Sistema Elétrico (ONS) - pessoa jurídica de direito privado, sem fins lucrativos, que, sob regulação e fiscalização da ANEEL, tem como objetivo o controle das funções de geração e transmissão no Sistema Interligado Nacional (SIN).

- Câmara de Comercialização de Energia Elétrica (CCEE) - pessoa jurídica de direito privado, sem fins lucrativos, que, sob regulação e fiscalização da ANEEL, tem como objetivo a gestão dos processos de contratação de compra e venda de energia no novo modelo.

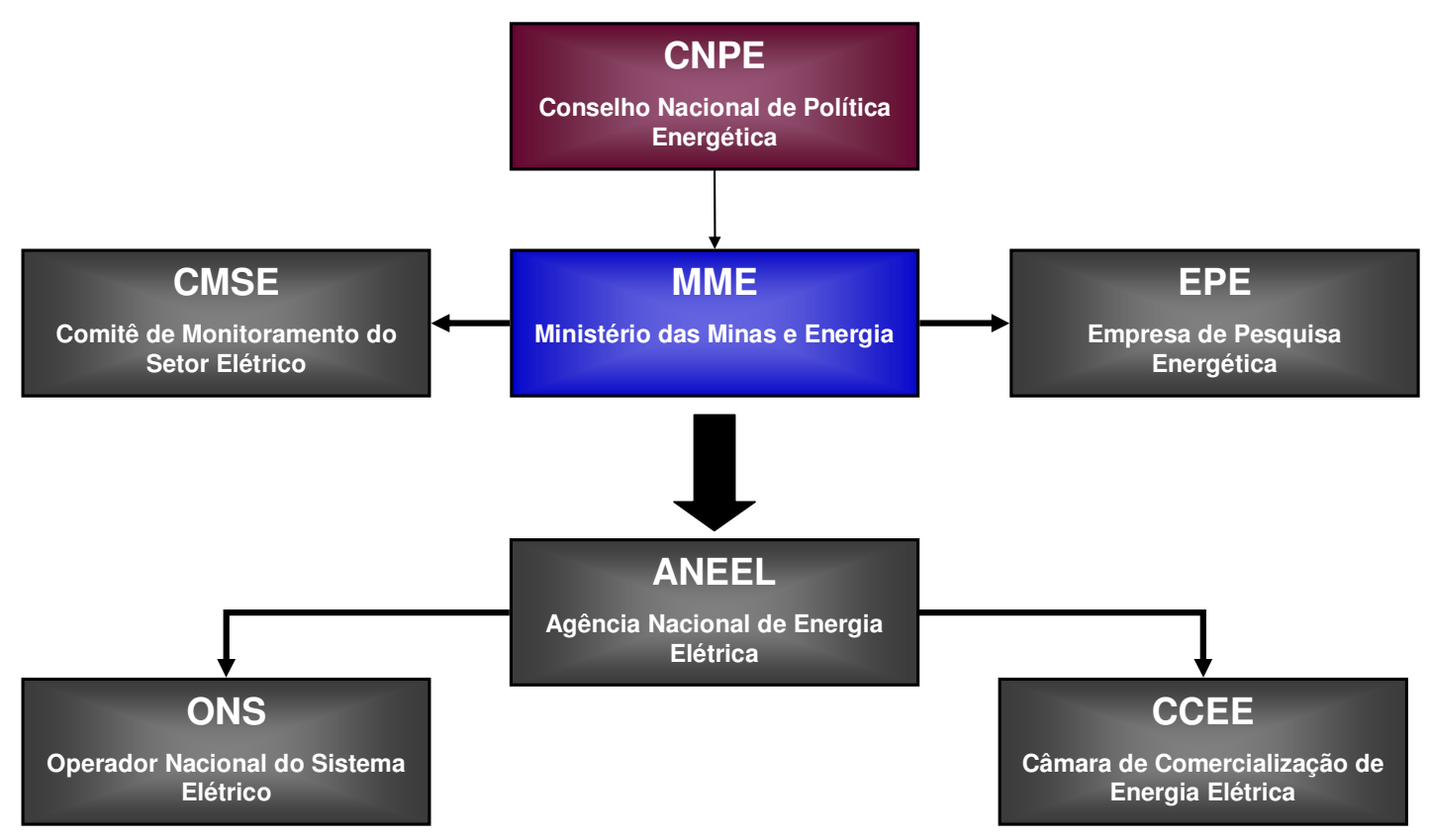

Figura 3.1 - Estrutura Institucional do Setor Elétrico

O setor elétrico opera segundo quatro segmentos de negócios com características específicas e graus distintos de regulação: Geração, Transmissão, Distribuição e Comercialização. 
O segmento de geração pode ser classificado como ambiente de competição controlada. A entrada de novo agente requer a autorização ou concessão do Poder Público. A concessão de uso pelo Poder Público ocorre em processos de licitação pública, cujo critério preponderante de julgamento de propostas é o menor preço para energia destinada ao atendimento do consumidor regulado.

$\mathrm{O}$ agente gerador pode comercializar energia em dois ambientes de mercado, o Ambiente de Contratação Regulada (ACR) e o Ambiente de Contratação Livre (ACL) - Figura [3.2]. As novas concessões exigem destinação de um percentual mínimo da energia produzida ao atendimento dos consumidores regulados.

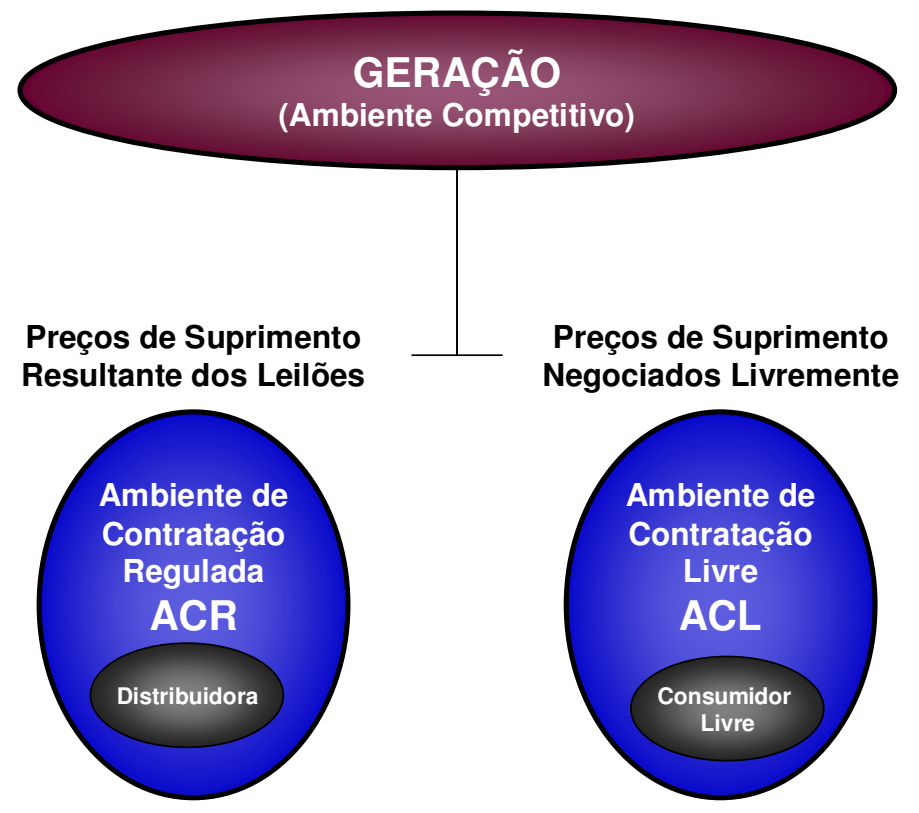

Figura 3.2 - Ambientes de Comercialização de Energia Elétrica Fonte: BRASIL (2003)

No ACR, o regulador exerce maior pressão sob as condições das transações de compra e venda de energia, em teoria, com objetivo de compatibilizar modicidade tarifária e atratividade de novos investimentos. No ACL, as transações são direcionadas pelas forças de mercado, firmadas bilateralmente entre agentes compradores e vendedores, sem intervenção do regulador. 
Os segmentos de transmissão e distribuição são classificados como monopólio natural ${ }^{20}$. Contudo, em ambos pode-se afirmar que a concorrência ocorre ex-ante, no evento de licitação de nova concessão.

No segmento de transmissão, o direito de implantação e exploração de novas linhas é concedido ao agente interessado, em leilões promovidos pelo MME, na qualidade de Poder Concedente, onde o critério de seleção do concessionário é o maior deságio sobre um valor de Receita Anual Máxima fixado. O valor de receita resultante do leilão constitui a fonte de remuneração do empreendedor, pelos investimentos realizados na implantação da nova linha e para cobertura dos custos de exploração desta, em contratos com vigência de 30 anos.

No segmento de distribuição, os contratos de concessão são também de 30 anos, prorrogáveis por igual período. A concessionária exerce exclusividade sobre determinada região de atuação e tem duas principais fontes de receita: o preço de fornecimento de energia pago pelos consumidores regulados e o encargo pelo uso do sistema de distribuição pago pelos consumidores livres, que adquirem energia no ACL, diretamente do agente gerador. $\mathrm{O}$ regulador exerce forte pressão sobre o repasse de custos ao consumidor final, como será visto em seção adiante.

Por fim, o segmento de comercialização é ambiente competitivo, caracterizado por reduzidas barreiras de entrada sob o ponto de vista de capacidade de investimento. O comercializador atua na intermediação entre o agente gerador e os consumidores livres, nas transações de compra e venda de energia realizadas no $\mathrm{ACL}^{21}$.

\footnotetext{
${ }^{20}$ Os setores de transmissão e distribuição são monopólios naturais. O monopólio natural se dá quando o tamanho ótimo de instalação e produção de uma empresa é suficientemente grande para atender toda a demanda de mercado, de forma que não haveria espaço para instalação de novas empresas. O monopólio natural pode se desenvolver, não apenas em situações onde seja imposto por lei, mas também como resultado natural de condições especiais de custo. CORREIA (1995) apud ABREU (1999) explica, da forma como reproduzido abaixo, a aplicação do conceito de monopólio natural para empresas do setor elétrico:

As características econômicas da distribuição da energia elétrica advêm dos condicionantes técnicos da indústria elétrica: existe a necessidade de conexão física entre a fonte geradora e o consumidor final; essa conexão é feita a partir de circuitos (aéreos ou subterrâneos) que são construídos nas vias públicas. Tanto por fatores técnicos quanto por questões econômicas, não se justifica construir dois circuitos para garantir competição no atendimento dos consumidores, pois essa competição se daria a preços elevados para os consumidores, se considerarmos uma distribuição eqüitativa das conexões.

${ }^{21}$ No novo modelo, os agentes de comercialização devem atuar exclusivamente no ACL. Contudo, os contratos de compra e venda de energia entre agentes de comercialização e concessionárias de distribuição, firmados em data anterior a março de 2004, vigorarão até a data de seu vencimento.
} 


\subsection{PLANEJAMENTO DA EXPANSÃO DO SETOR ELÉTRICO}

O planejamento da expansão do setor elétrico deverá compreender três etapas: Planejamento de longo prazo, Planejamento de médio prazo e Monitoramento.

O Planejamento de longo prazo deverá cobrir um horizonte não inferior a vinte anos, observado um ciclo de atividades quadrienal, em que se desenvolve o Plano de Expansão de Longo Prazo do Setor Elétrico (PELP), que estabelecerá a estratégia de longo prazo para o setor no que concerne às novas fontes de geração, aos grandes troncos de transmissão e às expectativas de desenvolvimento tecnológico e industrial para o país.

O desenvolvimento do PELP estará sob a responsabilidade da EPE, que deverá compatibilizar as necessidades de crescimento da oferta de energia no país com o desenvolvimento da matriz energética, com vistas à segurança de suprimento e o crescimento sustentado da matriz energética, segundo a natureza de suas fontes. Para tanto, a EPE, na composição do PELP, deverá realizar:

- estudos de recursos energéticos e de prospecção tecnológica nas áreas de geração e transmissão, incluindo a possibilidade de importação de energia e/ou insumos energéticos;

- estudos de mercado, com vistas a avaliar a evolução da demanda por energia elétrica, que deverá orientar o plano de expansão do sistema;

- estudos ambientais, visando identificar eventuais restrições à expansão da oferta e indicar possíveis soluções;

- estudo do Sistema Elétrico de Transmissão, com o objetivo de definir a estratégia de expansão da rede, especialmente dos grandes troncos de interligações regionais e das eventuais interligações internacionais;

- estudos hidrográficos, a fim de identificar a priorização dos estudos de inventário de bacias hidrográficas a serem desenvolvidos, bem como a necessidade de revisão ou atualização dos inventários já realizados.

O Planejamento de médio prazo deverá cobrir um horizonte não inferior a dez anos, observado um ciclo de atividades com periodicidade anual, em que se definem o Plano Decenal de Expansão dos Sistemas Elétricos (PDE) e o Programa Determinativo de Expansão 
de Transmissão (PDET). Assim tanto o PELP, como o PDE e o PDET, deverão ser desenvolvidos pela EPE.

O PDE será elaborado tendo como base as diretrizes do PELP e apresentará como principal produto, o ordenamento, por critério de mérito econômico, dos novos projetos de geração e transmissão. O ordenamento deverá refletir o atendimento à demanda projetada dentro de um critério de garantia pré-definido, ao mínimo custo global, sem prejuízo dos limites ambientais impostos.

O PDE será composto pelo resultado das seguintes atividades:

- consolidação da projeção de demanda para o horizonte do plano, considerando a necessidade de carga dos consumidores regulados e livres;

- estratégia de expansão dos sistemas de geração e transmissão;

- planejamento tático de expansão dos sistemas de geração e transmissão, incluindo: a indicação dos custos de referência para expansão, a lista de novos projetos de geração e, eventualmente, a indicação de projetos para apreciação pelo CNPE, os quais, se aprovados, serão também objeto de futuras licitações;

- de forma análoga ao descrito para o PELP, o PDE deverá indicar a priorização dos estudos de viabilidade de aproveitamentos hidrelétricos a serem desenvolvidos, bem como a necessidade de revisão ou atualização daqueles já realizados.

Em complemento ao PDE, será elaborado o PDET. No PDET, deverão estar indicados os reforços e ampliações na rede básica ${ }^{22}$, identificados e propostos pelo ONS, que exigirão providências de natureza executiva dentro de um horizonte de cinco anos. As necessidades de ampliação da rede, suscitadas por novos projetos de geração, estarão sujeitas à confirmação de planos posteriores e, portanto, não serão constantes do PDET.

Por fim, a atividade de monitoramento da expansão do sistema será de responsabilidade do CMSE. A atividade de monitoramento deverá considerar sempre um horizonte de trabalho de

\footnotetext{
${ }^{22}$ A terminologia "rede básica" é utilizada em referência às linhas com tensão igual ou superior a 230 $\mathrm{kV}$, que compõem o Sistema de Transmissão. As linhas com tensão inferior, por sua vez, compõem a rede de distribuição de energia elétrica (exceção feita às chamadas DIT's - Demais Instalações de Transmissão - que são linhas com tensão inferior a $230 \mathrm{kV}$, mas que são operadas pelas concessionárias de transmissão de energia elétrica).
} 
cinco anos, observado um ciclo permanente de atividades, em que se definem as providências para eventuais ajustes no programa de expansão em andamento.

O sistema de planejamento setorial constitui o eixo ao redor do qual toda a atividade setorial se desenvolve. O Plano Decenal de Expansão, que segue como vetor direcionador o Plano de Expansão de Longo Prazo do Setor Elétrico, é o grande referencial para o agente que, entre a produção e consumo de energia, interage no setor elétrico. O PDEE tem o mérito de orientar a expansão da geração e transmissão ao lançar um cenário de referência para implementação de novas instalações de geração e transmissão, necessárias para atender os requisitos de mercado, seguindo critérios de garantia de suprimento pré-estabelecidos. O plano é subsidio para a realização dos leilões de energia proveniente de novos empreendimentos de geração e novas instalações de transmissão, para a definição de que estudos de expansão de transmissão devem ser priorizados, bem como de quais estudos de inventário e viabilidade deverão ser realizados ou retomados.

Desta forma, o sistema de planejamento setorial configura-se como direcionador da expansão, é o convite ao investidor que aporta recursos no setor e principal apoio da sua decisão de investimento, bem como respaldo para a decisão de investimento em setores periféricos, mas que guardam relação de dependência com o setor elétrico.

Fica que a atividade de planejamento acaba por exercer um papel de instrumento por meio do qual o Estado, enquanto regulador e direcionador da política e dos planos de expansão setorial, firma um compromisso com a sociedade, no qual define e expõe seu plano para provisão do serviço público de energia elétrica segundo requisitos de segurança e quantidade que se consentem suficientes. E, pelo aspecto de compromisso assumido pelo Estado perante a sociedade, é adotado pelo investidor como vetor indutor e subsídio de sua decisão de investimento. 


\subsection{ESTRUTURA DO SETOR ELÉTRICO - MODELOS BÁSICOS}

A desverticalização é um instrumento eficaz para a instituição de mercados competitivos no setor elétrico, na medida em que evita que empresas verticalizadas utilizem-se da atuação em mercados de monopólio natural, como distribuição e transmissão, para coibir a atuação da concorrência em segmentos competitivos, como o submercado de geração.

A experiência internacional mostra que os movimentos de reestruturação do setor elétrico, em grande parte dos países em desenvolvimento, evidenciam a migração de modelos verticais para modelos competitivos, inicialmente no segmento de geração, evoluindo para liberalização de todo o mercado cativo. Os quatro modelos básicos de estrutura do setor elétrico, segundo DELOITTE TOUCHE TOMATSU EMERGING MARKETS, LTD (2004) são: o monopólio vertical, o modelo de um único comprador, o modelo de competição na comercialização de energia e o modelo de competição estendido ao mercado cativo, conforme descrito a seguir:

- Modelo Monopólio Vertical: ambiente em que o mercado é dominado por concessionárias de serviço público verticais com monopólio total nas suas regiões de atuação, auto-reguladas ou reguladas por uma terceira entidade.

- Modelo de um Único Comprador: mercado composto por empresas de geração (produtores independentes, concessionárias de geração ou concessionárias integradas), transmissão e distribuição, em que o despacho é centralizado, coordenado por uma única companhia, a qual detém exclusividade sobre a comercialização de energia, em transações de compra de energia dos geradores e venda aos distribuidores.

- Modelo de Competição na Comercialização: ambiente de mercado formado por empresas de geração (produtores independentes e concessionárias de geração), transmissão, distribuição e eventualmente comercialização em que, os dois últimos têm livre arbítrio para contratação de energia, diretamente junto ao gerador. As linhas de transmissão são operadas por um operador centralizado do sistema, que garante a otimização econômica do despacho e a prática não discriminatória de acesso à rede.

- Modelo de Competição no Nível de Consumo: ambiente de mercado similar ao descrito no modelo de competição na comercialização, com o incremento da competição no mercado consumidor. Neste modelo, os consumidores finais podem 
adquirir energia livremente dos distribuidores, comercializadores ou diretamente dos geradores.

Os quatro modelos básicos de estrutura do setor elétrico estão ilustrados a seguir, respectivamente, nas Figura[3.3], Figura[3.4], Figura[3.5] e Figura[3.6]. O grau de competição no funcionamento do setor aumenta, conforme se evolui da alternativa de monopólio vertical até a liberalização completa do mercado, conforme ilustração da Figura[3.7].
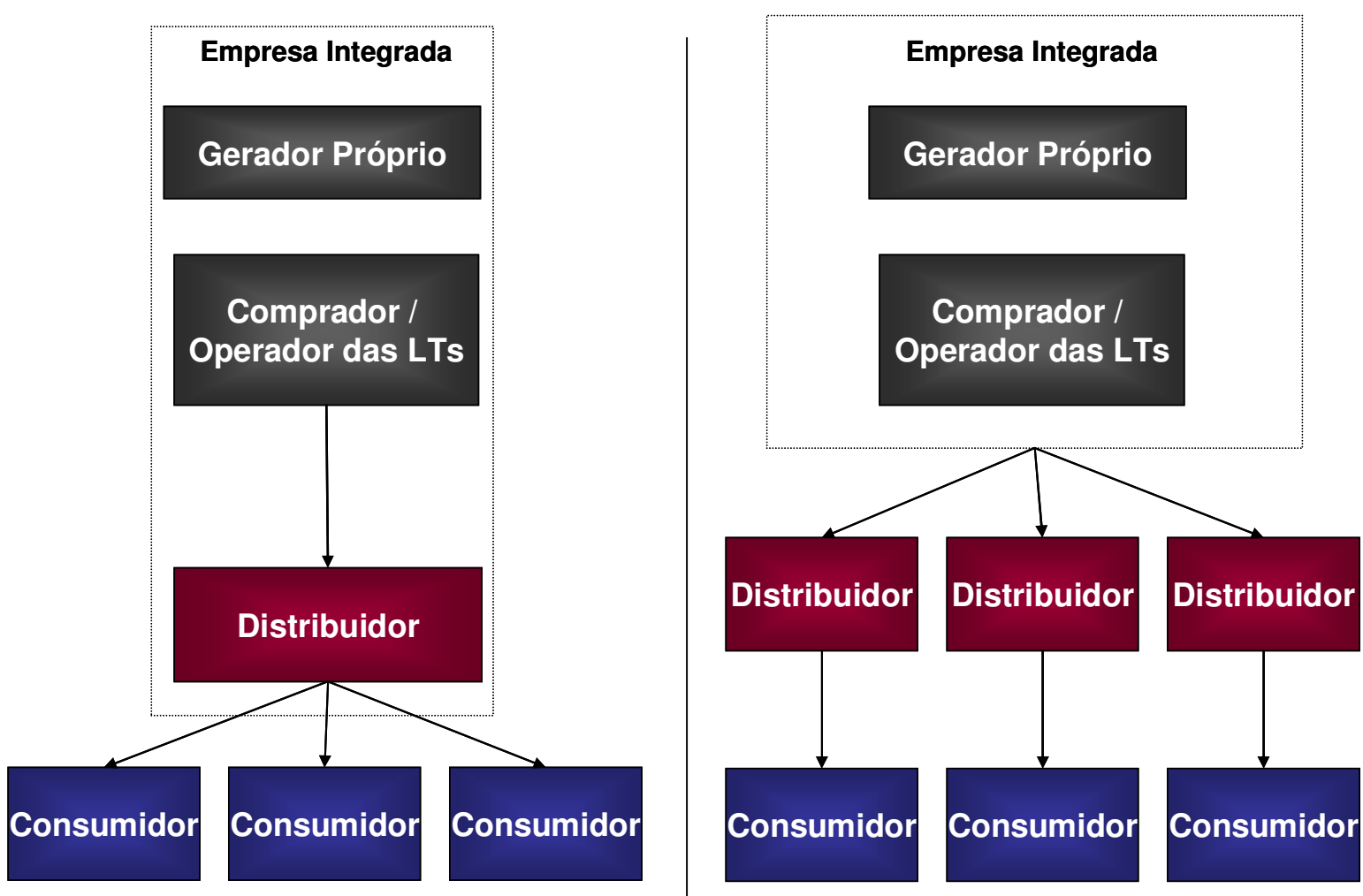

Figura 3.3 - Modelo de Monopólio Vertical

Fonte: (DELOITTE TOUCHE TOMATSU EMERGING MARKETS, LTD; 2004) 


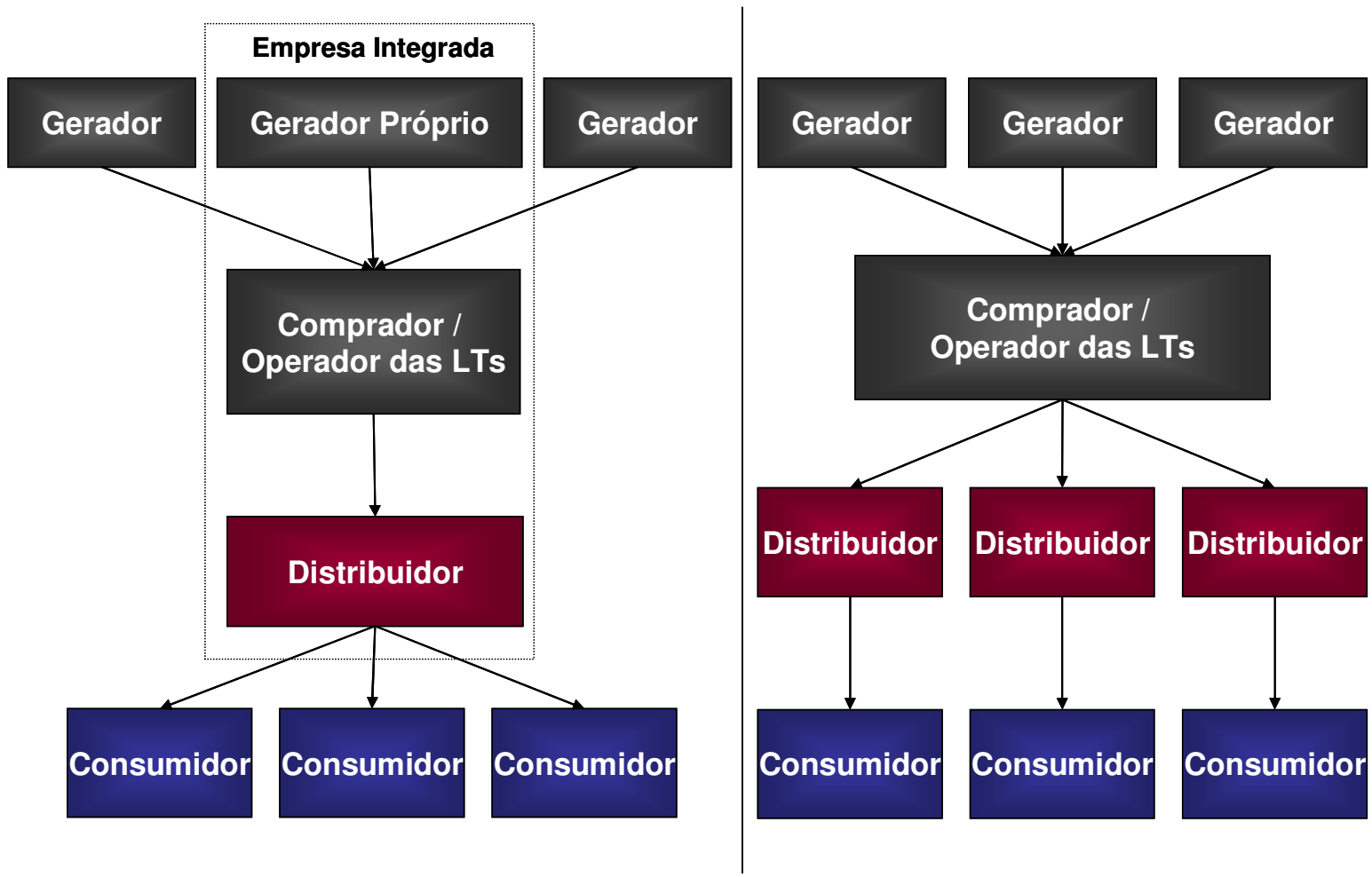

Figura 3.4 - Modelo de um Único Comprador Fonte: (DELOITTE TOUCHE TOMATSU EMERGING MARKETS, LTD; 2004)

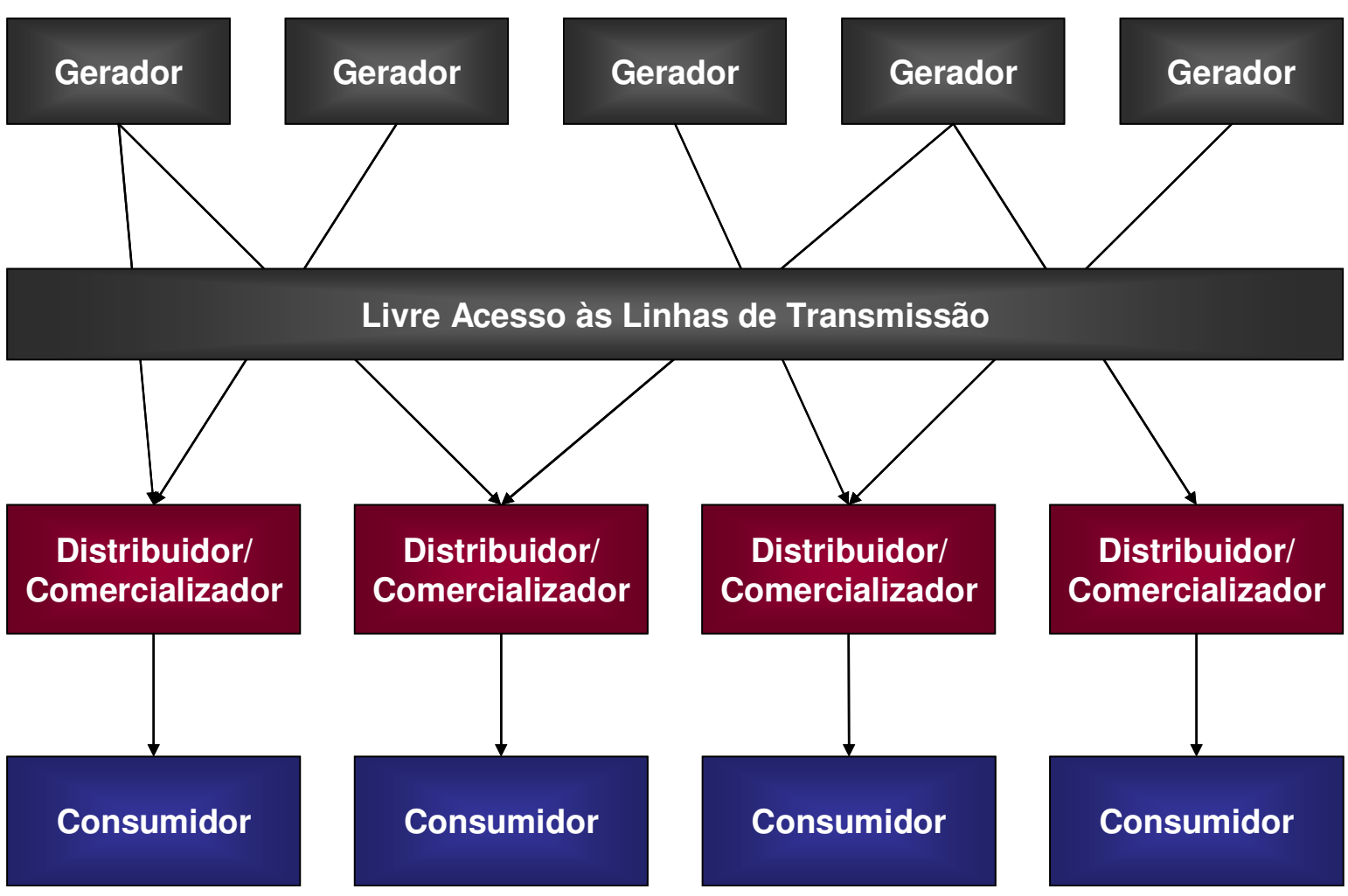

Figura 3.5 - Modelo de Competição na Comercialização

Fonte: (DELOITTE TOUCHE TOMATSU EMERGING MARKETS, LTD; 2004) 


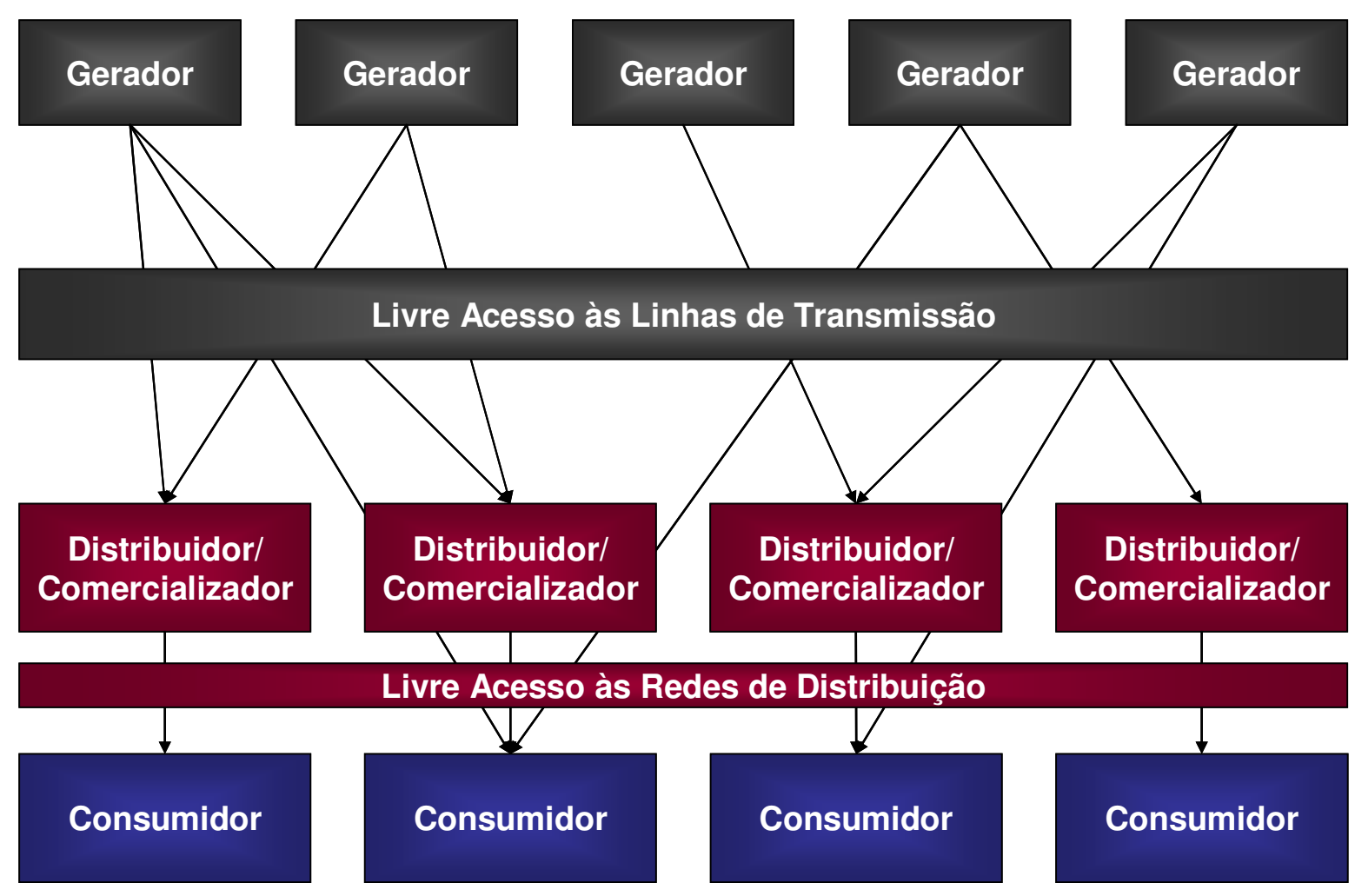

Figura 3.6 - Modelo de Competição no Nível do Consumo

Fonte: (DELOITTE TOUCHE TOMATSU EMERGING MARKETS, LTD; 2004)

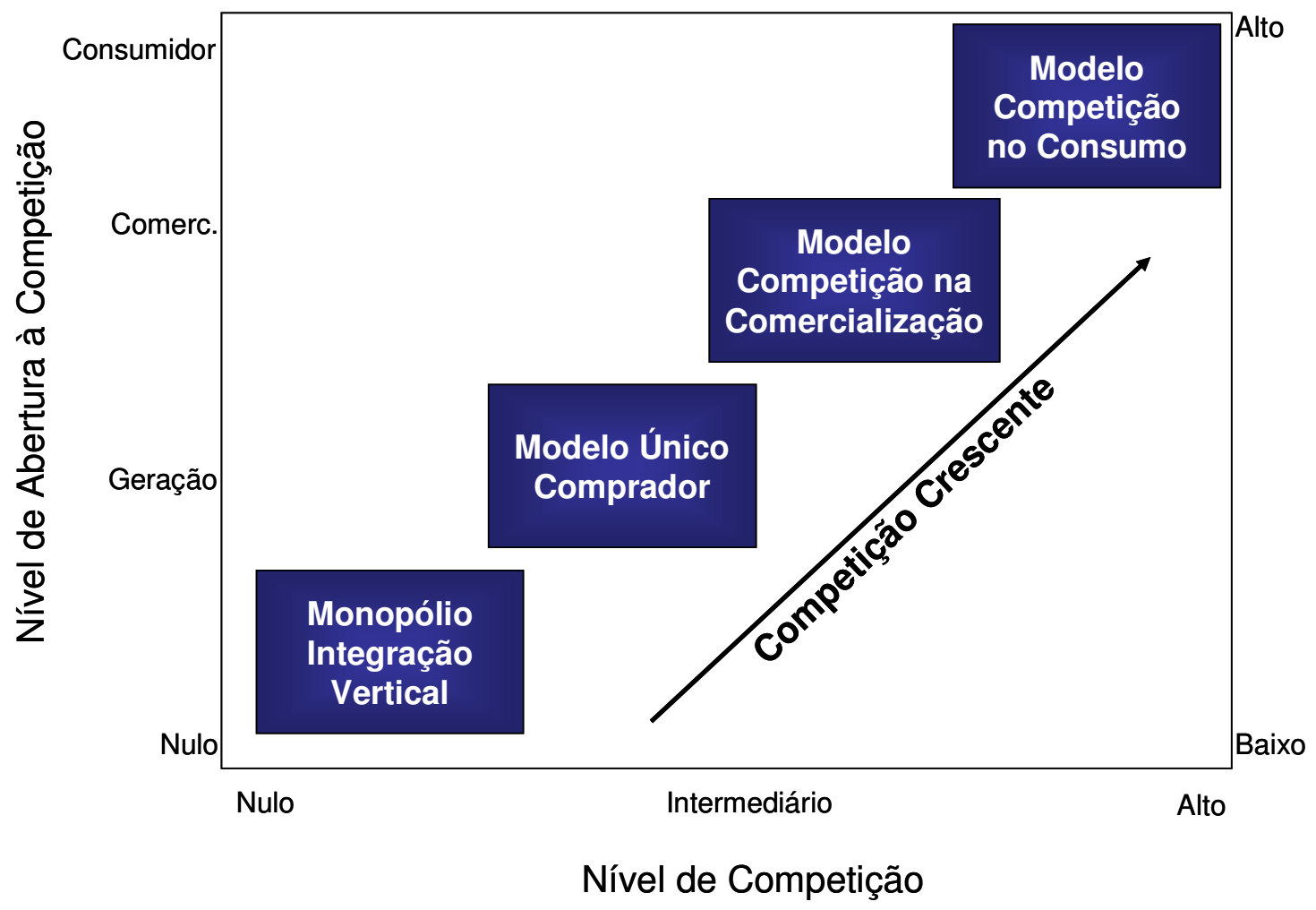

Figura 3.7 - Transição entre Modelos de Organização do Setor Elétrico

Fonte: (DELOITTE TOUCHE TOMATSU EMERGING MARKETS, LTD; 2004) 
A lei 10.848 em seu artigo oitavo, incisos $5^{\circ}$ e $7^{\circ}$ estabelece a obrigação de separação estrutural das empresas cuja atuação se dá no âmbito do SIN. Segundo o inciso $5^{\circ}$, as concessionárias de serviços públicos de distribuição de energia elétrica não poderão desenvolver atividades de geração e de transmissão de energia elétrica. O inciso $7^{\circ}$, de forma análoga, dispõe sobre a mesma proibição para as geradoras; conforme redação dada pela lei, as concessionárias e as autorizadas de geração de energia elétrica, que atuem no SIN, não poderão ser coligadas ou controladoras de sociedades que desenvolvam atividades de distribuição de energia elétrica.

Além desta, a lei mantém as premissas das reformas anteriores, quando institui o ONS como operador nacional do sistema de transmissão, a quem fica atribuída a responsabilidade pelo despacho centralizado do sistema, segundo critério de maior economia, bem como a coordenação e liberação do acesso de forma não discriminatória às linhas que compõe a rede básica.

O modelo brasileiro aproxima-se mais do modelo de competição na comercialização, no entanto, guarda também características do modelo de um único comprador e do modelo de competição no nível do consumo. No modelo brasileiro, as empresas de geração têm opção de transacionar a energia produzida em dois ambientes distintos de mercado: o ACR e o ACL.

No primeiro, as geradoras estabelecem contratos de longo prazo de compra e venda de energia, os CCEAR's, com empresas de distribuição que operam no mercado cativo ${ }^{23}$. Os geradores são contratados pelo mecanismo de leilão, segundo uma classificação crescente de preço de energia, até que seja atingida a quantidade demandada declarada por um pool de distribuidores, formado a cada evento de comercialização, pelas empresas que declaram interesse pela aquisição de nova energia. Uma vez concluído o processo de leilão, todos distribuidores fecharão contratos de longo prazo com cada um dos geradores, para a parcela da energia total transacionada correspondente à sua participação no total da quantidade demandada declarada.

\footnotetext{
${ }^{23}$ Mercado que engloba os consumidores com carga inferior a 3MW independente da tensão que demandem e os consumidores que, mesmo com demanda igual ou superior a $3 \mathrm{MW}$, não tenham exercido a opção pela contratação de energia diretamente com geradores ou comercializadores.
} 
Como todos os distribuidores travarão contrato com todos os geradores em proporções iguais, a comercialização no ambiente regulado, vista a partir de cada evento de comercialização, se assemelha àquela do modelo de um único comprador, uma vez que os distribuidores ficam sujeitos às condições da compra conjunta de energia pelo pool. A análise do processo de compra de energia no ACR, entretanto, vista a partir do conjunto de leilões de comercialização, guarda características do modelo de competição na comercialização, uma vez que o pool de empresas de distribuição, só tem efeito em cada leilão de comercialização. Desse modo, fica, ao distribuidor, instituída total liberdade para decidir sobre sua participação e necessidade de compra em cada evento de comercialização, prerrogativas estas que, remetem para o conceito do modelo de competição na comercialização ${ }^{24}$.

No ACL, os geradores poderão estabelecer contratos em condições livremente negociadas com comercializadores ou, diretamente, com os consumidores livres. O consumidor livre adquire diretamente a energia do gerador ou de um agente comercializador e paga aos agentes de transmissão e distribuição apenas a parcela da tarifa de energia correspondente ao uso das redes de alta e baixa tensão. Os usuários desta categoria de consumidores deverão estabelecer contratos de compra e venda de energia com os geradores, contratos associados à conexão e ao uso do sistema de transmissão, com empresas de transmissão e o ONS, e, analogamente, contratos referentes à conexão e ao uso das redes de baixa tensão com empresas de distribuição.

Assim, para transações no ACL, o modelo assume a configuração do modelo de competição no nível do consumidor. O número de consumidores livres no Brasil cresceu de forma expressiva nos últimos anos, principalmente diante de um cenário favorável de preços para o grande consumidor, nos anos que sucederam o racionamento de energia de 2001.

Conforme indicado na Tabela[3.1], em 2005, o consumo no mercado livre de energia alcançou $69.848 \mathrm{GWh}$, valor correspondente a $20 \%$ do consumo total de energia elétrica $344.608 \mathrm{GWh}$ - e aproximadamente $40 \%$ do consumo da classe industrial, que concentra

\footnotetext{
${ }^{24} \mathrm{O}$ pool de empresas de distribuição forma-se exclusivamente para cada evento de comercialização e extingue-se tão logo este seja findo. Cada pool é formado por um conjunto distinto de distribuidores.

A cada distribuidor, fica estabelecida a faculdade da decisão de participar ou não de cada evento e da quantidade de energia a contratar, o que implica em composição única de tarifa de suprimento para cada agente de distribuição. Caso a composição do pool fosse perene, composta pelo conjunto de concessionárias de distribuição em atividade, com a instituição de tarifa de suprimento compartilhada sempre, aí sim, teria sido instituído, na plenitude, no ACR, o modelo de um único comprador.
} 
quase que a totalidade dos consumidores livres. A Tabela[3.1] mostra ainda a distribuição geográfica do mercado de consumidores livres, que, ao final de 2005, estava concentrado na região sudeste, que reúne cerca de $67 \%$ deste mercado.

\begin{tabular}{|c|c|c|c|c|}
\hline \multicolumn{5}{|c|}{ DISTRIBUIÇÃO DO CONSUMO DE ENERGIA ELÉTRICA NO BRASIL } \\
\hline \multicolumn{5}{|c|}{ DISTRIBUIÇÃO POR SUBSITEMA / TIPO DE CONSUMIDOR (LIVRE OU CATIVO) / REGIÕES } \\
\hline \multicolumn{5}{|c|}{ DADOS CONSOLIDADOS DO ANO DE 2005 - ENERGIA CONSUMIDA (GWh) } \\
\hline & MERCADO CATIVO & MERCADO LIVRE & AUTOPRODUÇÃO & TOTAL \\
\hline BRASIL & 265.564 & 69.848 & 9.197 & 344.609 \\
\hline & $77,06 \%$ & $20,27 \%$ & $2,67 \%$ & \\
\hline Sistemas Isolados & 7.107 & & & 7.107 \\
\hline SIN & 258.457 & 69.848 & 9.197 & 337.502 \\
\hline Norte & 9.979 & 13.016 & 0 & 22.995 \\
\hline Nordeste & 43.933 & 3.385 & 19 & 47.337 \\
\hline SE / C.Oeste & 152.305 & 48.264 & 8.685 & 209.254 \\
\hline Sul & 52.240 & 5.183 & 493 & 57.916 \\
\hline \multicolumn{5}{|l|}{ REGIÕES } \\
\hline Norte & 13.618 & 6.925 & 0 & 20.543 \\
\hline Nordeste & 47.071 & 9.476 & 19 & 56.566 \\
\hline Sudeste & 133.943 & 47.001 & 8.685 & 189.629 \\
\hline Sul & 52.240 & 5.183 & 493 & 57.916 \\
\hline C.Oeste & 18.692 & 1.263 & 0 & 19.955 \\
\hline
\end{tabular}

Tabela 3.1 - Distribuição do Consumo de Energia Elétrica Fonte: (EPE; 2006a)

No novo modelo, independente do ambiente de contratação, a energia será despachada de forma centralizada, por mérito econômico, de acordo com os critérios estabelecidos pelo ONS, da forma como descrito no capítulo que segue. 


\subsection{A OPERAÇÃO CENTRALIZADA DO SISTEMA DE TRANSMISSÃO}

O estudo das experiências internacionais de reestruturação do setor elétrico, descrito nas seções anteriores, mostra ser fundamental para a promoção da competição nos segmentos de geração e comercialização e para garantia da eficiência do sistema, o tratamento regulatório adequado dos segmentos caracterizados naturalmente como monopólio, precipuamente o segmento de transmissão.

O segmento de transmissão deve ser configurado de forma a proporcionar acesso indiscriminado à rede básica a todo agente de geração e comercialização, por meio da tarifação justa, das restrições à congestão de linhas de transmissão e do estimulo a expansão da rede nos pontos onde seja necessário.

A experiência internacional sugere, como medida para atender tais requisitos, a separação estrutural do segmento de transmissão dos demais segmentos ${ }^{25}$ e a constituição de um órgão independente para operação centralizada do sistema, cujas atribuições contemplem o despacho energético, segundo critério de menor custo, e a intermediação entre os proprietários da linha e seus usuários, mediante a cobrança e repasse de tarifas pelo uso do sistema. Adicionalmente, a operação independente do sistema é recomendada em sistemas com predominância da fonte hidráulica e grande número de usinas em cascata, como o brasileiro, como forma de otimizar o uso do recurso hídrico.

No Brasil, em 1999, foi criado o ONS para controle operacional da rede básica. O ONS, desde sua criação, absorveu as atribuições até então ao cargo do Grupo Coordenador de Operação Interligada (GCOI), cuja coordenação era exercida pela Eletrobrás. O ONS é formado por representantes dos agentes setoriais de cada um dos segmentos de geração, transmissão e distribuição, bem como comercializadores e consumidores livres ligados diretamente à rede básica.

\footnotetext{
${ }^{25}$ No Brasil, ainda persistem grupos econômicos com atuação integrada nos segmentos de geração e transmissão, entretanto, os riscos de manipulação de mercado são mitigados pelo: (i) planejamento da expansão e operação centralizada do sistema, sob responsabilidade da EPE e ONS respectivamente; (ii) pela atual sistemática de licitação de projetos de expansão da rede básica - os proponentes vencedores constroem as novas linhas, operam-na e comprometem-se a mantê-la disponível, por tempo mínimo definido contratualmente, mediante remuneração fixa pré-pactuada e (iii) pela exigência imposta na lei 10.848 de separação contábil de empresas com atuação vertical.
} 
Conforme redação dada pela lei 10.848 de 2004, o ONS atualmente tem as seguintes atribuições:

- planejamento, programação da operação e o despacho centralizado da geração, com vistas à otimização dos sistemas eletroenergéticos interligados;

- coordenação e supervisão dos centros de operação dos sistemas elétricos;

- supervisão e controle da operação dos sistemas eletroenergéticos interligados nacionais e das interligações internacionais;

- contratação e administração dos serviços de transmissão de energia elétrica e respectivas condições de acesso, bem como serviços ancilares;

- proposição ao Poder Concedente das ampliações das instalações da rede básica, bem como dos reforços dos sistemas existentes, a serem considerados no planejamento da expansão dos sistemas de transmissão;

- proposição de regras para a operação das instalações de transmissão da rede básica do SIN, a serem aprovadas pela ANEEL.

No novo modelo do setor elétrico, são firmados contratos de concessão com duração de 30 anos, entre a União e os concessionários de transmissão, que regem a prestação dos serviços de transmissão. O concessionário de transmissão, no novo modelo, deve celebrar, com ONS e usuários da rede básica, outros quatro tipos de contratos, a saber:

- Contrato de Conexão ao Sistema de Transmissão (CCT): contrato que estabelece os termos e condições da conexão dos usuários ao sistema de transmissão, a ser celebrado entre cada empresa transmissora e cada usuário.

- Contrato de Prestação de Serviços de Transmissão (CPST): contrato celebrado entre empresa transmissora e o ONS, que estabelece os termos e condições da prestação de serviço de transmissão por empresa detentora de ativo de transmissão pertencente à rede básica, conforme regramento de administração e supervisão do ONS.

- Contrato de Uso do Sistema de Transmissão (CUST): contrato celebrado entre o ONS, a concessionária de transmissão e os usuários, que estabelece os termos e condições do uso da rede básica por um usuário, incluindo a prestação dos serviços de transmissão pelas concessionárias de transmissão, mediante controle e supervisão do ONS e a 
prestação, pelo ONS, dos serviços de coordenação e controle da operação dos sistemas elétricos interligados.

- Contrato de Constituição de Garantia (CCG): contrato celebrado entre os usuários da rede básica, o ONS e as concessionárias de transmissão, representadas pelo ONS, para garantir o recebimento dos valores devidos pelos usuários às concessionárias e ao ONS pelos serviços por estes prestados.

No modelo de despacho centralizado, em um sistema hidrotérmico como o brasileiro, o operador do sistema assume papel fundamental na manutenção do equilíbrio de mercado, porque suas decisões de despacho direcionam o custo marginal de operação do sistema e, portanto, o patamar do preço da energia no curto prazo. O operador do sistema, no modelo de despacho centralizado, é o único agente que tem algum poder de gestão sobre o risco hidrológico, porque é quem exerce controle sobre o nível dos reservatórios hídricos. Cabe ao operador, através do uso racional dos reservatórios, zelar pela segurança do abastecimento em curto e médio prazos e transmitir sinais consistentes de preços de energia para o mercado, sob a ótica dos investidores de geração e dos consumidores de energia elétrica. 


\subsection{A REGULAÇÃO dO MERCADO CATIVO: ASPECTOS DA POLÍtICA TARIFÁRIA ${ }^{26}$}

O mercado cativo é composto por todos os consumidores com carga inferior a $3 \mathrm{MW}^{27}$ e por aqueles que, ainda que com demanda de carga igual ou superior a $3 \mathrm{MW}$, não tenham exercido a opção de compra direta de energia elétrica de agente produtor ou de empresa de comercialização, conforme prevê a legislação do setor.

As tarifas de energia, no mercado cativo, são definidas com base em dois componentes: demanda de potência e consumo de energia. A demanda de potência é medida em $\mathrm{kW}$ e é calculada considerando a média da potência elétrica solicitada pelo consumidor à empresa distribuidora, durante um intervalo de tempo especificado, normalmente 15 minutos, faturada pelo maior valor medido durante o período de fornecimento, normalmente de 30 dias. $\mathrm{O}$ consumo de energia é medido em kWh ou MWh e corresponde ao valor acumulado pelo uso da potência elétrica disponibilizada ao consumidor, ao longo de um período de consumo, também normalmente de 30 dias. A depender da modalidade de fornecimento, não são pagas tarifas associadas à demanda de potência.

As tarifas de energia elétrica estão estruturadas em dois grandes grupos de consumo: grupo "A" e grupo "B". Os consumidores classificados como integrantes do grupo "A" são aqueles atendidos pela rede de alta tensão, de 2,3 a 230 quilovolts $(\mathrm{kV})$. As tarifas do grupo "A" estão divididas em outras duas modalidades de fornecimento: convencional e horo-sazonal. $\mathrm{Na}$ modalidade convencional, a aplicação de tarifas de consumo de energia e demanda de potência independe das horas de utilização do dia e dos períodos do ano. Na modalidade horo-sazonal, são aplicadas tarifas diferenciadas de consumo de energia elétrica e de demanda de potência, de acordo com as horas do dia e períodos do ano, de modo a racionalizar energia, buscando incentivar a programação do consumo nos horários do dia e nos meses do ano em que a energia é mais barata.

Os consumidores do grupo "B" são aqueles atendidos em redes de tensão inferior a 2,3 kV. Os consumidores que compõe o grupo "B" pagam apenas o componente de consumo da tarifa

\footnotetext{
${ }^{26}$ Com base em ANEEL (2005a)

${ }^{27}$ Exceção aos consumidores com carga igual ou superior a $500 \mathrm{~kW}$, que façam uso da permissão para compra direta de pequenas centrais hidrelétricas.
} 
geradoras por meio de leilões no ambiente de contratação regulada. As regras de repasse dos custos de geração, em geral, procuram incentivar o distribuidor a preconizar a compra de energia nos leilões realizados cinco anos antes do início de suprimento, através da fixação de restrições ao repasse para a energia adquirida em leilões realizados três anos antes do suprimento, um ano antes do suprimento e em leilões de ajuste.

O segundo grupo de receitas denominado parcela "B" é composto dos custos associados diretamente à operação dos serviços de distribuição, bem como dos custos de depreciação e remuneração dos investimentos da empresa para o atendimento do serviço.

Como nos demais contratos de concessão, quando da assinatura do contrato, os concessionários de distribuição reconhecem que a tarifa pactuada em contrato e sua sistemática de reajuste e revisão são, respectivamente, suficientes e adequadas para cobertura dos custos de operação e manutenção do serviço, assim como para retornar os recursos investidos a uma taxa admitida como atrativa. Os contratos de prestação de serviços de distribuição estabelecem três mecanismos para atualização de tarifas, conforme indicado abaixo:

\section{$\underline{\text { Reajuste Tarifário Anual }}$}

O Reajuste Tarifário Anual é o mecanismo de restabelecimento anual do poder de compra da receita obtida pelo concessionário. Em cada evento de reajuste tarifário, a receita anual da concessionária, praticada nos doze meses findos anteriores ao reajuste, deverá ser multiplicada por um fator, denominado Índice de Reajuste Tarifário Anual (IRT), definido na Equação[2.1]:

$$
I R T=\frac{V P A_{1}+V P B_{0} \times(I \pm X)}{R A_{0}} \quad \text { Equação[2.1] }
$$

Onde:

$\mathbf{R A}_{\mathbf{0}}$ - Valor da receita anual fixado na Data de Referência Anterior - DRA;

VPA $_{1}$ - Novo valor da parcela "A" das receitas do concessionário, calculado na Data do Reajuste em Processamento - DRP, obtido pela somatória dos valores vigentes de cada um dos itens detalhados na primeira coluna da Tabela[3.2]; 
$\mathbf{V P B}_{\mathbf{0}}$ - Valor da parcela de custos não gerenciáveis - parcela "B" - em DRA, obtido pela diferença entre o valor da Receita Anual fixado em DRA - $\mathrm{RA}_{0}$ - e o valor da parcela "A" da receita vigente no mesmo período - $\mathrm{VPA}_{0}$;

I - Número índice obtido pela divisão do índice IGP-M da Fundação Getúlio Vargas, ou índice que contratualmente vier a sucedê-lo, do mês anterior à DRP pelo do mês anterior à DRA;

X - Número índice fixado pela ANEEL, a cada revisão periódica, a ser subtraído ou adicionado ao I correspondente a cada reajuste tarifário anual.

\section{Revisão Tarifária Periódica}

O processo de revisão tarifária periódica tem como principal objetivo avaliar, após decorrência de um período previamente fixado - atualmente de quatro a cinco anos - o equilíbrio econômico financeiro da concessão. Enquanto nos reajustes anuais a parcela "B" é apenas corrigida monetariamente, no evento de revisão tarifária procede-se com a determinação de nova tarifa considerada necessária para cobertura dos custos operacionais e para remuneração adequada dos investimentos considerados prudentes pelo regulador, segundo uma determinada estrutura de eficiência operacional e um padrão de qualidade de serviço de referência definido pelo regulador $^{28}$. Além do reposicionamento tarifário, no evento de revisão tarifária, se estabelece novo valor para o índice $\mathrm{X}$ referido na fórmula anterior.

$\mathrm{O}$ fator $\mathrm{X}$, quando positivo, é um importante mecanismo de incentivo à produtividade. Ao se fixar um fator redutor ao índice de correção inflacionária, utilizado para restabelecimento do poder de compra da parcela de itens gerenciáveis da receita de distribuição, cria-se um incentivo à busca por ganhos de eficiência produtiva por parte do agente distribuidor, que buscará compensar a redução imposta sobre o índice de reajuste de suas receitas ${ }^{29}$.

${ }^{28}$ A análise da eficiência operacional e da prudência dos investimentos é feita pelo regulador baseado em parâmetros constituídos a partir da simulação de uma empresa de referência responsável pela operação e manutenção das instalações elétricas, gestão comercial de clientes e direção e administração da área geográfica da concessionária de distribuição em análise, que presta esses serviços em condições de eficiência e adaptação econômica ao ambiente no qual desenvolve sua atividade.

${ }^{29} \mathrm{O}$ índice de reajuste anual de tarifas, da maneira como formulado, estabelece o repasse integral das metas de ganhos de produtividade - 0 índice $X$ da fórmula do IRT fixado pelo regulador - ao consumidor final. Desta forma, a empresa distribuidora que atinge exatamente as metas de produtividade arbitradas pelo regulador não aufere ganho real algum, tão somente mantém preservado o valor real de suas tarifas, ao corrigi-las integralmente pelo valor da inflação. Com vistas a criar um ambiente de incentivo à produtividade, através do prêmio pela competência do 


\section{$\underline{\text { Revisão Tarifária Extraordinária }}$}

Além dos eventos de reajuste e revisão tarifária, o contrato de concessão de serviços de distribuição estabelece ainda o mecanismo de Revisão Tarifária Extraordinária, por meio do qual, a ANEEL poderá, a qualquer tempo, por solicitação da empresa de distribuição, proceder com a revisão das tarifas em decorrência de alterações significativas comprovadas na estrutura de custos das empresas de distribuição, durante o intervalo entre eventos de revisão tarifária, com vistas à reposição do equilíbrio econômico financeiro do contrato.

concessionário, o que se propõe, tendo por base ALENCAR (1998), é que se inclua na fórmula de cálculo do IRT um fator multiplicador sobre o índice $X$, cujo valor varia no intervalo 0 e 1 , com a finalidade de repartir os benefícios de ganhos de produtividade entre o consumidor final e o agente distribuidor. Com tal objetivo, sugere-se o uso do tratamento matemático proposto por ALENCAR (1998) e reproduzido a seguir: Em substituição ao tratamento matemático do índice de reajuste segundo a expressão $R t=I_{t}-X_{t}$, onde $I_{t}$ é a inflação do período e $X_{t}$ é o fator de produtividade, o autor sugere o cálculo do reajuste pela seguinte expressão: $R t=(1+\mathrm{tt}) /(1+\alpha \mathrm{Xt})-1$, onde $\alpha$ é o fator de ajuste que distribui o ganho de produtividade entre o usuário e o empreendedor. Se $\alpha$ é 0 , todo ganho de produtividade fica com o empreendedor, se $\alpha$ é 1 todo ganho é repassado ao usuário, se $\alpha$ assume valores entre 0 e 1 o ganho é distribuído entre usuários e o empreendedor. 


\subsection{A CONCESSÃO DE NOVOS APROVEITAMENTOS E A CONTRATAÇÃO DE ENERGIA}

\subsubsection{A Comercialização de Energia no ACR}

O inciso II do art. $2^{\circ}$ do decreto 5.163 de 30 de julho de 2004, estabelece a obrigação às concessionárias de distribuição e consumidores livres de garantir o atendimento a $100 \%$ da demanda por energia e potência de seus mercados, por intermédio de contratos registrados na CCEE.

Para atendimento a tal obrigação, as concessionárias de distribuição deverão adquirir, por meio de leilões realizados no ACR, a energia elétrica proveniente de novos empreendimentos ${ }^{30}$ e empreendimentos existentes.

Conforme critério estabelecido pelo decreto 5.163, os agentes de distribuição deverão, até $1^{\circ}$ de agosto de cada ano, informar ao Ministério de Minas e Energia - MME a previsão dos seus mercados para os cinco anos subsequientes, como também, até 60 dias antes dos leilões de comercialização de energia, declarar a quantidade de energia a ser contratada para atendimento à totalidade de suas cargas.

Os leilões de contratação de energia elétrica serão promovidos direta ou indiretamente pela ANEEL, observadas diretrizes definidas pelo MME, que deverão fixar os montantes, por modalidade contratual, a serem licitados. Os leilões ocorrerão de cinco a três anos antes do início de suprimento para energia elétrica proveniente de novos empreendimentos e um ano antes desta data, para energia elétrica proveniente de empreendimentos de geração existente. A partir de 2009, os agentes de distribuição poderão contratar um montante de energia proveniente de empreendimentos existentes equivalente ao seu montante de reposição,

\footnotetext{
${ }^{30}$ Entendem-se como novos empreendimentos de geração, aqueles que, até a data de publicação do edital do leilão de comercialização, não sejam detentores de concessão, autorização ou permissão, ou que sejam parte de empreendimentos já existentes objeto de ampliação, nesta hipótese, restrito ao acréscimo da capacidade instalada. Excepcionalmente, até 31 de dezembro de 2007, nos leilões para contratação de energia proveniente de novos empreendimentos, poderá ser ofertada a energia produzida por empresas geradoras que atendam cumulativamente os seguintes requisitos: (i) que tenham obtido outorga de concessão ou autorização até 16 de março de 2004; (ii) que tenham iniciado a operação comercial a partir de $1^{\circ}$ de janeiro de 2000 e (iii) cuja energia não tenha sido contratada até 16 de março de 2004.
} 
correspondente à quantidade de energia dos contratos que se extinguirem nos anos de ocorrência dos referidos leilões ${ }^{31}$.

Em ocorrendo necessidade, a ANEEL poderá ainda promover leilões específicos para contratações de ajuste pelos agentes de distribuição, com prazo de início de suprimento de, no máximo, quatro meses e períodos máximos de suprimento de dois anos, a fim de possibilitar a complementação pelos agentes de distribuição, do montante necessário para o atendimento à totalidade de suas cargas. A energia contratada por cada agente de distribuição nos leilões de ajuste não poderá exceder a um por cento da sua carga total já contratada. A Figura[3.8] traz a cronologia dos leilões de comercialização de energia elétrica, tendo por base o ano de início de suprimento (ano “A”).

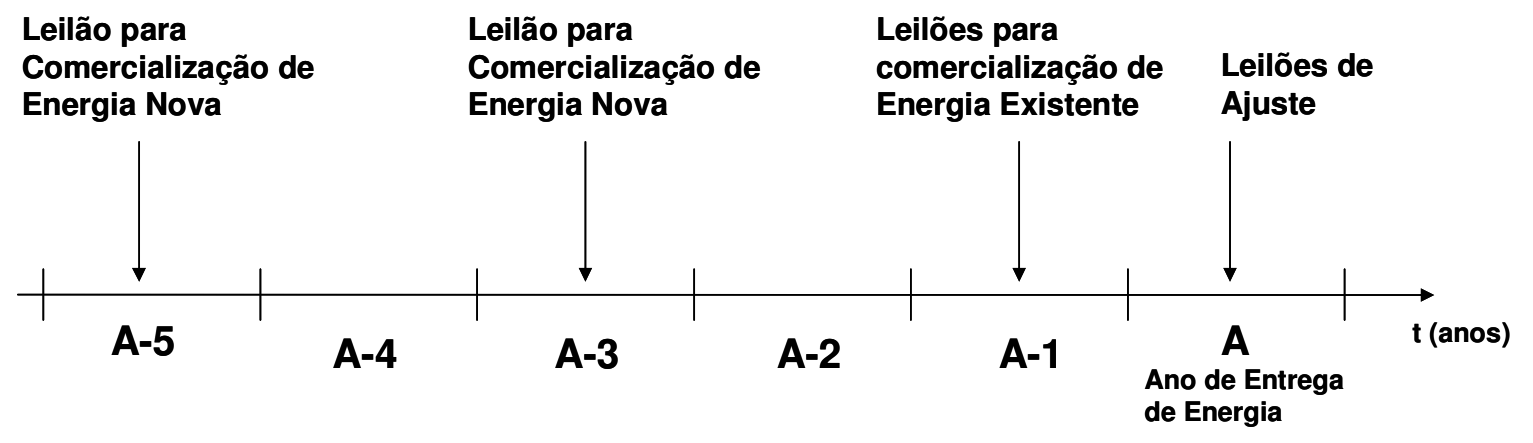

Figura 3.8 - Leilões de Comercialização de Energia Elétrica Adaptado de CASTRO (2004)

Os preços praticados nos leilões serão definidos pelas condições de oferta e demanda por energia em cada evento de comercialização, observado o preço teto fixado pela ANEEL. Nos leilões de energia proveniente de empreendimentos existentes realizados até 2009, o preço máximo de aquisição de energia será fixado pela ANEEL. Após este ano, o preço de aquisição não deverá superar o valor médio resultante dos leilões de compra de energia elétrica de novos empreendimentos realizados cinco anos antes da data de realização da demanda, em que o ano de início de suprimento coincida com o ano de início de fornecimento do leilão de energia existente em questão.

Os vencedores dos leilões de energia proveniente de empreendimentos novos ou existentes deverão celebrar CCEAR com o conjunto dos agentes de distribuição compradores. Os

\footnotetext{
${ }^{31}$ Em havendo oferta excedente no leilão de energia existente, a contratação de energia do agente de distribuição pode atingir até $105 \%$ do seu montante de reposição.
} 
CCEAR's deverão prever: (i) prazos de, no mínimo, 15 e, no máximo, 30 anos, contados do início de suprimento de energia proveniente de novos empreendimentos; e (ii) prazos de, no mínimo, 5 e, no máximo, 15 anos, contados do ano seguinte ao da realização do leilão de compra de energia de empreendimentos existentes, desde que o termo final do contrato de suprimento não supere a data de extinção do contrato de concessão de geração. O CCEAR poderá apresentar duas modalidades distintas: quantidade de energia elétrica ou disponibilidade de energia elétrica.

$\mathrm{Na}$ primeira modalidade, o agente de geração deve, obrigatoriamente, disponibilizar ao sistema todo o montante de energia contratado. Assim, nos casos em que a geração efetiva seja inferior ao volume de energia contratado, o gerador deve adquirir energia de outros agentes, de forma que o volume disponibilizado ao sistema, em seu nome, alcance o valor com o qual se comprometeu contratualmente.

$\mathrm{Na}$ segunda modalidade, o gerador recebe um valor fixo anual para, não necessariamente gerar, mas sim manter disponível ao sistema a usina pronta para operar. Os contratos são firmados tendo por base um valor de face, até o qual a usina pode ser requisitada e um valor mínimo de geração, definido pelo gerador e fixado contratualmente que, obrigatoriamente, deve ser despachado pelo ONS, a despeito do critério de despacho pelo menor custo. Pela geração superior ao valor mínimo, quando esta ocorrer, o gerador receberá o custo variável marginal, também pré-definido contratualmente.

$\mathrm{Na}$ primeira modalidade contratual, tomando como exemplo o caso das usinas de fonte hídrica, os riscos hidrológicos e eventuais exposições financeiras no mercado de curto prazo da CCEE são assumidos pelos agentes de geração enquanto que, na segunda, estes riscos são transferidos aos agentes de distribuição, o que traz implicações ao preço de aquisição da energia. A assunção dos riscos de geração por parte dos agentes de distribuição, faz com que os custos de aquisição da energia para o distribuidor sejam menores na modalidade de disponibilidade de energia do que na modalidade de quantidade de energia.

Apesar do decreto 5.163 prever a flexibilidade dos CCEAR's no que se refere ao prazo e à modalidade contratual, os leilões de energia nova realizados até então previram, obrigatoriamente, contratos na modalidade quantidade de energia com duração de 30 anos, para energia proveniente da fonte hídrica, e contratos na modalidade disponibilidade de 
energia com duração de 15 anos, para usinas de fonte térmica. Desta forma, os geradores hídricos ficam expostos aos riscos de quantidade, ou, aos riscos hidrológicos e de eventual exposição financeira no mercado de curto prazo.

No caso de térmicas, os contratos devem ser firmados na modalidade disponibilidade de energia, de forma a extrair os riscos de complementação térmica do ambiente do investidor em geração. Os contratos por disponibilidade reduzem o risco do investimento, sob o ponto de vista do empreendedor, e ensejam para maior atratividade do investimento, sem onerar o custo global da energia para o consumidor final. Por meio destes contratos, os investidores em geração térmica vêem assegurada a remuneração dos recursos imobilizados na implantação das plantas e o consumidor final se beneficia da necessária complementação térmica do sistema e da maior segurança sobre o abastecimento, pagando pelo combustível térmico somente quando seu consumo faz-se efetivamente necessário, no âmbito da operação centralizada do despacho, que ocorre sob o critério de maior economia para o sistema.

Os CCEAR's na modalidade disponibilidade de energia, para plantas térmicas, prevêem o pagamento por parte do distribuidor de uma Receita Fixa, necessária para devolver e remunerar os investimentos mobilizados, pelo gerador térmico, na implantação da usina, cobrir os custos fixos incorridos pelo empreendedor e os custos variáveis correspondentes à declaração de inflexibilidade ${ }^{32}$ da planta.

A energia gerada superior à inflexibilidade será também destinada ao distribuidor, de forma proporcional à parcela da garantia física ${ }^{33}$ da planta com ele contratada. O distribuidor deverá pagar, pela energia que excede a inflexibilidade, valor suficiente apenas para cobrir o custo operacional marginal, uma vez que todos os demais componentes da estrutura de custos do empreendedor já estão cobertos pela Receita Fixa.

\footnotetext{
32 A inflexibilidade corresponde à quantidade mínima de geração da usina, informada pelo empreendedor ao regulador, às vésperas do leilão de comercialização de energia, que deve ser, obrigatoriamente, considerada pelo ONS no despacho energético, a despeito do critério de otimização econômica do sistema.

${ }^{33}$ A garantia física da usina corresponde ao lastro de geração, definido pelo MME, como a quantidade máxima de energia relativa a cada usina térmica ou hídrica, que poderá ser utilizada para comprovação de atendimento de carga ou comercialização por meio de contratos.
} 


\section{Leilões de Energia Proveniente de Novos Empreendimentos ${ }^{34}$}

Conforme estabelece o artigo 22 do decreto 5.163, excepcionalmente até 31 de dezembro de 2007, nos leilões para contratação de energia proveniente de novos empreendimentos, poderá ser ofertada a energia produzida por empresas geradoras que atendam cumulativamente os seguintes requisitos: (i) que tenham obtido outorga de concessão ou autorização até 16 de março de 2004; (ii) que tenham iniciado a operação comercial a partir de $1^{\mathrm{o}}$ de janeiro de 2000 e (iii) cuja energia não tenha sido contratada até 16 de março de 2004.

Abaixo, descreve-se, de forma sucinta, a sistemática dos leilões de energia nova, nos moldes dos eventos a serem realizados até fim de 2007. De forma geral, os leilões que contemplam a outorga de novos aproveitamentos hidrelétricos e a comercialização da energia proveniente de novos empreendimentos são divididos em duas fases ${ }^{35}$ :

\section{Primeira Fase}

Participam da Primeira Fase apenas os empreendedores interessados em obter a concessão dos novos empreendimentos de fonte hídrica licitados pela ANEEL. A Primeira Fase está dividida em duas etapas, Etapa Inicial da Primeira Fase, onde os empreendedores proponentes oferecerão, para os empreendimentos licitados, lance para a tarifa de fornecimento em [R \$MWh], até teto definido pelo MME. O sistema organizará as ofertas por hierarquia de preços e concederá o Direito de Participação na fase subseqüente do leilão ao empreendedor que propuser a menor tarifa de fornecimento se, a diferença entre sua oferta e a do segundo proponente for superior a 5\%. Em não ocorrendo tal fato, terá início a segunda etapa da Primeira Fase, denominada Etapa Contínua.

Nesta etapa, os empreendedores com lances compreendidos entre $100 \%$ e $105 \%$ da menor oferta, partindo do Preço Corrente Inicial, de valor igual ao da menor oferta da etapa anterior,

\footnotetext{
${ }^{34}$ Com base em ANEEL (2005c;2005d;2006b;2006c;2006d;2006e)

${ }^{35}$ Os termos destacados em itálico correspondem à terminologia utilizada pela ANEEL no documento de detalhamento da sistemática do leilão realizado em out/06 e estão destacados apenas para facilitar o entendimento do andamento dos leilões. A sistemática aqui resumida reflete, com maior fidelidade, o leilão de out/06 em detrimento dos eventos ocorridos anteriormente. Entretanto, salvo algum detalhe ou nome distinto, a lógica e a dinâmica dos processos de outorga de novas concessões e comercialização de energia proveniente de novos empreendimentos ocorreu, em essência, da forma como reproduzido a seguir.
} 
disputam o Direito de Participação, oferecendo preços de lance formados pelo Preço Corrente Inicial subtraído de múltiplos inteiros de um valor, definido pela ANEEL, como Decremento Mínimo da Primeira Fase, até o momento em que um dos proponentes deixe de impostar novo lance, durante um tempo superior ao Tempo para Inserção de Lance.

Este processo deverá se repetir para todos os empreendimentos em licitação, até que seja concedido a um único empreendedor, para cada empreendimento para o qual exista oferta, o Direito de Participação na segunda fase do leilão.

Após adquirir o direito de prosseguir no leilão, o proponente vendedor deverá indicar a parcela da energia assegurada do empreendimento que destinará à comercialização no ACR, que deverá respeitar um percentual mínimo definido pelo MME.

O critério de licitação das concessões de novos aproveitamentos hidrelétricos é a menor tarifa para energia destinada à comercialização no ACR. Como a definição da quantidade de energia destinada ao ACR e ao ACL constitui prerrogativa do empreendedor, este pode admitir como estratégia, destinar um volume mínimo de energia ao ACR, e dada a pequena representatividade deste volume de energia no todo, submeter, no processo licitatório, para esta parcela, um preço extremamente baixo, que lhe assegure a concessão do novo aproveitamento. Como medida para punir ações desta natureza, o MME impõe uma redução, ou compensação, sobre o preço pelo qual o empreendedor venderá sua energia, como estímulo à modicidade tarifária no ACR. A redução no preço de venda no ACR será tão maior quanto maior for o percentual da energia assegurada destinado ao $\mathrm{ACL}^{36}$.

\section{$\underline{\text { Segunda Fase }}$}

Nesta fase, juntam-se aos empreendedores que obtiveram a concessão dos novos aproveitamentos hidrelétricos, empreendedores de empreendimentos com concessão ou autorização já obtidas. A Segunda Fase do leilão compõe-se de duas etapas.

\footnotetext{
${ }^{36} \mathrm{O}$ cálculo da compensação é feito com base na seguinte expressão: Comp $=\left(\alpha^{*} \mathrm{X}^{\star *} \mathrm{E}_{\mathrm{ASS}}\right)^{\star}\left(\mathrm{P}_{\mathrm{MAR}}-\right.$ $P_{\text {OFER }}$ ); onde: $x$ é o percentual da energia assegurada destinado ao ACL; $\alpha$ é um valor de 0 a 1 , definido pelo MME para o leilão em questão; $E_{A s s}$ é a energia assegurada da usina; $P_{M A R}$ é o preço marginal do processo de licitação, a mais alta proposta de preço dentre as ofertas submetidas, e $\mathrm{P}_{\mathrm{OFER}}$ é o preço submetido pelo proponente em questão.
} 
Na Etapa Inicial da Segunda Fase, os proponentes vendedores de energia proveniente da fonte térmica e da fonte hídrica submeterão simultaneamente seus lances, para um determinado montante de energia, considerando o Preço Inicial da Segunda Fase da oferta termo e da oferta hidro. O Preço Inicial da Segunda Fase para a oferta hidro será o menor valor entre o Preço Teto do Produto Hidro, definido pelo MME, e o maior preço de lance dos empreendedores que detiveram o Direito de Participação na primeira etapa. Para a oferta termoelétrica, o preço inicial será equivalente ao Preço Teto do Produto Termo, também definido previamente pelo MME.

Caso a Quantidade Total Ofertada, após a Etapa Inicial da Segunda Fase, seja igual ou inferior à Quantidade Total Declarada, o leilão será encerrado. De forma contrária, caso a Quantidade Total Ofertada seja superior à Quantidade Total Declarada, será calculada a Oferta de Referência para o Produto Termo e para o Produto Hidro e terá início, de forma segregada segundo a natureza dos Produtos, a Etapa Final da Segunda Fase. A Oferta de Referência será calculada pelo sistema, multiplicando-se a parcela da quantidade demandada declarada associada a cada um dos Produtos, por um Fator de Referência, cujo valor deverá ser maior que 1 .

Para cada um dos produtos, a Etapa Final da Segunda Fase compõe-se de Rodadas Uniformes e Rodada Discriminatória. Nas Rodadas Uniformes, o sistema disponibilizará o Preço de Lance e os proponentes interessados ofertam determinada Quantidade de Lotes ${ }^{37}$, tendo por base o Preço de Lance fixado pelo sistema. A rodada uniforme repete-se, tantas vezes forem necessárias, até que a Quantidade Total Ofertada atinja valor inferior à Oferta de Referência, sendo que, em cada rodada o Preço de Lance assume novo valor, equivalente ao Preço de Lance da rodada anterior reduzido do Decremento da Segunda Fase.

Ao se registrar Quantidade Total Ofertada inferior à Oferta de Referência, o sistema retornará à penúltima rodada da etapa uniforme resgatando os Lances Válidos, para dar início à Rodada Discriminatória. Na Rodada Discriminatória, o proponente deverá submeter o Preço de Lance tendo por base a Quantidade de Lotes Ofertada e, como limite superior de preço, o Preço de Lance da penúltima Rodada Uniforme. Após a confirmação do lance submetido ou

$\overline{{ }^{37} \mathrm{O} \text { lote equivale à quantidade }}$ de energia de $1 \mathrm{MW}$ médio e corresponde à menor parcela de um produto. 
o decurso do Tempo para Inserção de Lance, o sistema classificará os lotes em Lotes Atendidos ou Lotes Não Atendidos, com base na Quantidade Demandada de cada produto, e não mais pela Oferta de Referência.

Após a conclusão da Rodada Discriminatória, o sistema realiza o ajuste das quantidades de energia, com vistas à efetivação dos CCEAR's. O sistema deverá ratear os lotes negociados entre todos os compradores, na proporção das quantidades demandadas declaradas, respeitando-se o ano de início de suprimento.

\subsubsection{A Comercialização de Energia no ACL}

Além da opção pelo abastecimento pelas empresas concessionárias de distribuição, os consumidores cuja carga supere $3 \mathrm{MW}$ poderão fazer a opção pela compra de energia diretamente do agente gerador. Neste caso, a aquisição de energia dar-se-á mediante operações de compra e venda de energia elétrica envolvendo os agentes concessionários, permissionários e autorizados de geração, comercializadores e consumidores livres, no que se convencionou denominar, Ambiente de Contratação Livre (ACL). No ACL, as relações comerciais entre os agentes serão livremente pactuadas e regidas por contratos bilaterais de compra e venda de energia elétrica.

Segundo dispõe o decreto 5.163, os consumidores potencialmente livres, ou seja, consumidores atendidos pelas concessionárias de distribuição com carga superior a $3 \mathrm{MW}$, apenas poderão adquirir energia elétrica de um outro fornecedor, no ano subseqüente ao da declaração formal da opção pela condição de consumidor livre ao seu agente de distribuição. De outro lado, os consumidores livres com intenção de retornar à condição de consumidor regulado, só poderão fazê-lo, após a formalização da solicitação ao agente de distribuição local, com antecedência mínima de cinco anos.

As restrições de prazo para saída e retorno à posição de consumidor regulado têm como propósito evitar comportamento especulativo por parte dos grandes consumidores, que, na hipótese de não restrição legal, teriam total liberdade para aderir ou abandonar o status de 
consumidor livre, de forma a aproveitar-se de quaisquer movimentos tópicos de comportamento dos preços no ambiente de livre contratação.

A imposição da antecedência mínima de cinco anos para o retorno à posição de consumidor regulado está associada ao prazo para início de suprimento dos leilões de energia nova no novo modelo. O prazo de cinco anos permite ao agente distribuidor incluir a demanda associada ao consumidor que pretende retornar à condição de consumidor regulado nas suas requisições de compra nos leilões de cinco anos, onde a energia contratada será predominantemente hídrica, de baixo custo. O retorno de consumidores livres à condição de regulado, desta forma, não implica em necessidade adicional de compra de energia em leilões de três anos, leilões de energia existente ou leilões de ajuste e nem implica em risco de penalidades para a concessionária de distribuição por falta de lastro.

A opção de consumidor livre deverá ser exercida após a segmentação e imediata substituição dos contratos de fornecimento de energia com os agentes de distribuição por contratos de compra de energia com os agentes geradores, contrato de conexão e uso do sistema de transmissão, celebrados respectivamente com a concessionária de transmissão de energia elétrica e com ONS, e contrato de uso e de conexão à rede de distribuição, firmados com a concessionária de distribuição, na hipótese das instalações do consumidor não estarem ligadas diretamente na rede de básica.

\subsubsection{A Comercialização de Energia no Mercado de Curto Prazo}

O novo modelo contempla ainda o funcionamento do mercado de curto prazo ou mercado spot. É no mercado de curto prazo que ocorre o processamento da contabilização da energia elétrica contratada e consumida no Brasil. Basicamente, a contabilização realizada semanalmente no mercado de curto prazo leva em consideração toda a energia contratada por parte dos agentes e toda a energia efetivamente verificada, consumida ou gerada.

Conforme artigo $2^{\circ}$ da lei 10.848 , todas as empresas de distribuição e consumidores livres deverão garantir o atendimento a $100 \%$ de suas cargas, em termos de energia e potência, por intermédio de contratos registrados na CCEE. Empresas geradoras, distribuidoras, 
comercializadores e consumidores livres de energia elétrica registram no CCEE os montantes de energia contratada, assim como os dados de medição, para que, desta forma, se possa determinar quais as diferenças entre o que foi produzido ou consumido e o que foi contratado. Essa diferença é liquidada ao Preço de Liquidação das Diferenças (PLD).

O PLD será publicado pela CCEE e calculado antecipadamente, com periodicidade máxima semanal, com base no Custo Marginal de Operação (CMO), limitado por preços mínimo e máximo. O CMO é o principal parâmetro indicativo do preço da energia no mercado de curto prazo, pois representa o custo de operação do sistema submetido a um incremento de carga, sem considerar a possibilidade de expansão de capacidade. O preço da energia no mercado de curto prazo é o próprio valor de CMO determinado pelos modelos computacionais aplicados na simulação operativa do sistema (CASTRO, 2004).

Os valores limites do PLD, a serem estabelecidos pela ANEEL, deverão considerar como fronteira superior os custos variáveis de operação dos empreendimentos termelétricos disponíveis para o despacho centralizado e, como fronteira inferior, a soma do custo de operação e manutenção das usinas hidrelétricas e do custo relativo à compensação financeira pelo uso dos recursos hídricos e royalties ${ }^{38}$. Em seu turno, o cálculo do PLD por submercado de energia, deverá levar em conta as restrições aos fluxos de energia elétrica no SIN e os ajustes das quantidades de energia pela aplicação do fator de perdas na transmissão, relativamente a um ponto comum de referência, definido para cada submercado.

Do ponto de vista dos agentes de distribuição e comercialização, a despeito da contabilização e liquidação serem realizadas em base mensal, as penalidades decorrentes dos desvios contratuais serão objeto de conciliação anual pela CCEE, de modo a levar em conta o impacto da sazonalidade do consumo, bem como variações intra-anuais que possam ser compensadas. Para efeito da aplicação das penalidades, os distribuidores deverão comprovar a contratação de $100 \%$ de seu mercado, medido em base anual.

Quando o distribuidor ou o agente de comercialização estiver sobrecontratado, a liquidação das diferenças produzirá ganhos ou perdas de receita, caso o PLD seja, respectivamente, maior ou menor que o preço de aquisição no pool. No ACR, a ANEEL deverá considerar

\footnotetext{
${ }^{38}$ Atualmente, referem-se exclusivamente aos valores pagos por Itaipu a 16 municípios, 15 no estado do Paraná e 1 no Estado do Mato Grosso do Sul, afetados pelo reservatório da usina.
} 
repasse dos custos de aquisição de energia elétrica às tarifas dos consumidores finais para até $3 \%$ de sobrecontratação. Na situação inversa, quando a distribuidora estiver subcontratada, estará sujeita ao pagamento de penalidades. A subcontratação implica, ainda, em exposição aos preços no mercado de curto prazo, situação em que será permitido repasse às tarifas, no ano subseqüente ao da conciliação, do valor mínimo entre o PLD e o Valor Anual de Referencial (VR) ${ }^{39}$.

Do ponto de vista dos geradores, apenas poderá ser objeto de contratação a energia assegurada certificada pela ANEEL. Se o gerador estiver contratado na modalidade quantidade de energia, a liquidação das diferenças entre o montante contratado e a energia gerada, ou o crédito de energia, após a aplicação do Mecanismo de Realocação de Energia (MRE), para as hidrelétricas, será baseada no PLD.

O MRE é um mecanismo de compartilhamento de risco hidrológico, segundo o qual o montante de energia efetivamente gerado pelo sistema hidrelétrico é, para efeito de contabilização financeira, distribuído entre todas as usinas do sistema, de forma proporcional à participação da energia assegurada de cada usina na energia assegurada de todo o sistema hídrico - Figura [3.9]. Desta forma, pode ocorrer que, usinas cujo despacho ocorreu em patamar superior ao valor assegurado, após a aplicação do MRE, para efeito de contabilização financeira, registrem quantidade de energia inferior à assegurada. Estas usinas devem liquidar a diferença, se existir, entre a energia a elas atribuída após o MRE e a energia comprometida em contratos de longo prazo, cujo limite máximo corresponde à energia assegurada, no mercado de curto prazo.

A energia, no âmbito do MRE, é transferida entre hídricas, ao custo mínimo da água, baseado em tarifa de otimização definida pela ANEEL, para cobertura dos custos incrementais incorridos na operação e manutenção das usinas e para pagamento da tarifa de compensação financeira por uso de recursos hídricos, calculado com base no montante de energia gerada.

O gerador, contratado na modalidade quantidade de energia, receberá um valor fixo, pelo montante de energia fixado em contrato e as diferenças contratuais serão liquidadas pelo PLD.

${ }^{39}$ Para os anos de 2007 e 2008, o VR será o valor calculado como média ponderada da energia proveniente de novos empreendimentos adquirida nos leilões realizados até final de 2005 . O VR deverá considerar os valores médios ponderados de aquisição e as quantidades da energia adquirida para entrega nos anos de 2008 a 2010. 
Quando a energia atribuída ao gerador após aplicação do MRE é superior à quantidade de energia dos seus contratos, o gerador recebe pelo excedente, no mercado de curto prazo, ao PLD. Na situação inversa, quando a energia atribuída ao gerador após a aplicação do MRE é inferior à quantidade de energia dos seus contratos, o gerador paga pelo déficit, no mercado de curto prazo, o PLD - Figura [3.10]. Se o gerador estiver contratado na modalidade disponibilidade de energia, não haverá liquidação de diferenças para o gerador, pois o resultado líquido da contabilização das diferenças, da totalidade dos geradores contratados nesta modalidade, será alocado ao pool de distribuidores.

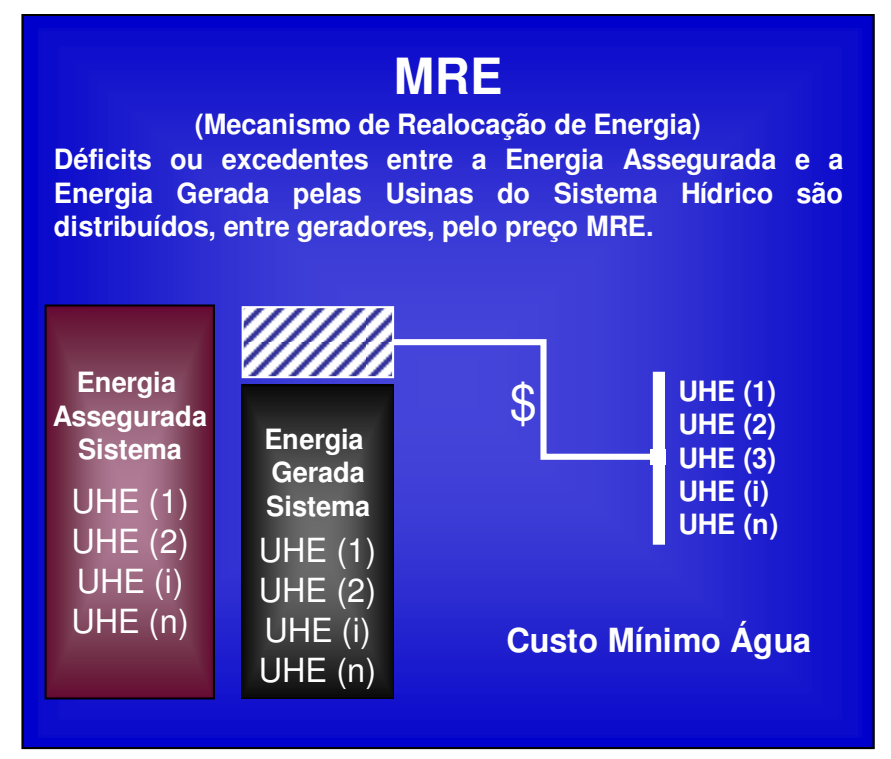

Figura 3.9 - Mecanismo de Realocação de Energia - MRE

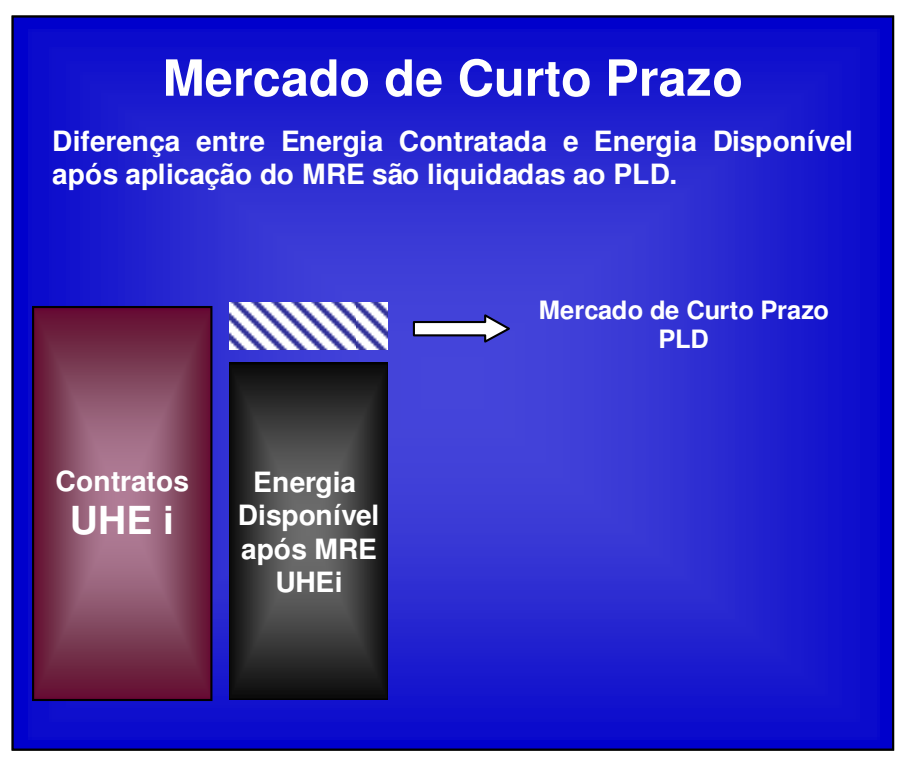

Figura 3.10 - Mercado de Curto Prazo 


\subsection{RETROSPECTO DOS LEILÕES DE ENERGIA NOVA REALIZADOS EM 2005 E 2006}

Desde a instituição das leis 10.847 e 10.848 e do decreto 5.163, foram realizados três leilões para comercialização de energia proveniente de novos empreendimentos.

Conforme mencionado na seção anterior, segundo disposição do artigo 22 do decreto 5.163, excepcionalmente até 31 de dez/07, poderá ser ofertada a energia proveniente de empreendimentos que, cumulativamente, tenham obtido outorga de concessão ou autorização até 16 de mar/04, que tenham iniciado a operação comercial a partir de 01 de jan/00 e cuja energia não tenha sido contratada até 16 de mar/04. Após esta data, os empreendimentos enquadrados neste grupo, para comercialização no ACR, utilizar-se-ão dos leilões de comercialização de energia proveniente de empreendimentos existentes.

A permissão constante do artigo 22 do decreto 5.163 fez com que a maior parcela da oferta de energia comercializada nos leilões de novos empreendimentos fosse proveniente dos empreendimentos enquadrados nesta categoria, dando, aos leilões até então realizados, um viés de transição entre os modelos institucionais do setor elétrico anterior e posterior à lei 10.848. A análise sobre o volume de energia comercializado nos leilões de novos empreendimentos realizados, mostra que, mais que a outorga e a comercialização de novas concessões ou autorizações, os leilões priorizaram acelerar a comercialização da energia descontratada proveniente de empreendimentos cujas concessões foram outorgadas no modelo anterior.

O primeiro leilão de comercialização de energia proveniente de novos empreendimentos foi realizado em dezembro de 2005. Dentre os eventos realizados em 2005 e 2006, foi o que apresentou escopo mais amplo. O leilão contemplou a comercialização de energia para entrega em 3, 4 e 5 anos, contemplou a oferta da energia de fonte térmica e hídrica, bem como a outorga de novas concessões hidrelétricas.

Neste leilão, a licitação de novas concessões ocorreu conforme descrito na seção anterior, sendo que o teto para os lances submetidos pelos proponentes interessados nas novas concessões foi de 116 [R $\$ / M W h]$. Após obter o direito de participação, os proponentes 
vendedores das novas concessões participaram, ao lado dos demais empreendedores cujos empreendimentos foram enquadrados no artigo 22 do decreto 5.163, do evento para comercialização de energia frente ao pool de concessionárias de distribuição.

Durante a fase de comercialização, não foi arbitrado preço teto para a energia, a não ser para os proponentes da primeira fase, que não podiam submeter oferta de preço, durante as fases seguintes, superior àquela com a qual obtiveram o direito de participação. Contudo, o ambiente de competição entre proponentes de nova concessão e proponentes enquadrados no artigo 22 do decreto 5.163, bem como a prerrogativa do MME para arbitragem do preço inicial da última etapa do leilão, acabaram por balizar os preços praticados no leilão em patamar próximo aos 116 [R \$MWh].

No leilão de dezembro de 2005, foram contratados 3.286 MW médios para uma oferta total de 5.722 MW médios, 30\% proveniente de fonte hídrica e $70 \%$ de fonte térmica. Foram outorgadas sete novas concessões de fonte hídrica, perfazendo um montante de $800 \mathrm{MW}$ de potência instalada, equivalente a um montante assegurado de 469 MW médios.

Os números divulgados pelo MME, após o leilão, não fizeram referência ao percentual de energia contratada relativamente à demanda declarada para o leilão, mas sim à posição, após o evento de comercialização, do índice de atendimento da necessidade de carga total estimada para os anos de 2008, 2009 e 2010. Segundo números do MME, a contabilização da energia comercializada no leilão elevou o índice de atendimento sobre a demanda nacional estimada para, 100\% em 2008, 98,8\% em 2009 e 95,5\% em 2010. Contudo, o índice de atendimento, quando calculado relativamente à demanda declarada pelos distribuidores para o leilão, resultou sensivelmente baixo. Segundo SALES (2006), apenas 49\% e 53\% das quantidades demandas informadas para os anos de 2008 e 2009, respectivamente, foram atendidas neste leilão.

A média de preço para contratação de energia hídrica no primeiro leilão foi de: 106,95 [R \$MWh] para início de suprimento em 2008, 113,89 [R \$MWh] para início de suprimento em 2009 e 114,83 [R \$MWh] em 2010. Para energia de fonte térmica os preços foram de: 132,$26 ; 129,24 ; 121,81$ [R $\$ / \mathrm{MWh}$ ], respectivamente, para início de suprimento em 2008, 2009 e 2010. 
O segundo leilão de energia nova foi realizado em jun/06 e contemplou a comercialização de energia para entrega em três anos. O segundo leilão, em função do prazo, não contemplou a outorga de novas concessões hidrelétricas.

Neste leilão, foram comercializados $1.682 \mathrm{MW}$ médios, para uma demanda informada pelas empresas distribuidoras de 1.616 MW médios sendo, aproximadamente 39\% de fonte térmica e $61 \%$ de fonte hídrica, com preços tetos definidos pelo MME para energia hídrica e térmica de, respectivamente, $125[\mathrm{R} \$ / \mathrm{MWh}]$ e $140[\mathrm{R} \$ / \mathrm{MWh}]$. O preço médio para a energia comercializada para o produto hidro foi de $126,8[\mathrm{R} \$ \mathrm{MWh}]^{40} \mathrm{e}$, para o produto termo de $132,4[\mathrm{R} \$ / \mathrm{MWh}]$.

Em 10 de outubro de 2006, foi realizado o terceiro leilão de energia nova que contemplou a outorga de novas concessões hidrelétricas e a comercialização de energia proveniente de novos empreendimentos para entrega em cinco anos, a partir do início de 2011. No terceiro leilão de energia nova, foram colocadas em licitação quatro novas concessões, mas outorgadas apenas duas, por falta de oferta para as demais.

Foram comercializados 1.104 MW médios, sendo 51,54\% proveniente do produto hidro e $48,46 \%$ proveniente do produto termo. A demanda declarada pelas distribuidoras foi de 1.243 MW médios, em outros termos, o índice de atendimento à demanda declarada para o leilão foi de aproximadamente $89 \%$.

As duas novas concessões outorgadas - UHE Dardanelos e UHE Mauá - destinaram quase que a totalidade da suas Energias Asseguradas ao ACR, perfazendo aproximadamente 339 MW médios dos 569 MW médios do produto hidro, ou aproximadamente $60 \%$ do total de energia proveniente desta fonte. O preço teto arbitrado para o produto hidro foi novamente $125[\mathrm{R} \$ / \mathrm{MWh}]$ e, para o produto termo, $140[\mathrm{R} \$ \mathrm{MWh}]$. O preço médio da energia comercializada foi de 120,86 [R $\$ / M W h]$ para o produto hidro e 137,44 [R $\$ / M W h]$ para o produto termo.

\footnotetext{
${ }^{40} \mathrm{O}$ preço médio do produto hidro resultou maior que o preço teto, em face da correção do preço de venda dos empreendimentos cujas concessões foram resultantes de licitação em que tenha sido observado o critério do máximo pagamento pelo Uso do Bem Público (UBP). Para estes empreendimentos, a sistemática do leilão admite o acréscimo ao preço de lance, de um valor referente à diferença entre o $\mathrm{UBP}_{\text {original }} \mathrm{e}$ o $\mathrm{UBP}_{\text {referência, }}$ definido pelo $\mathrm{MME}$ para efeito do leilão. $\mathrm{O}$ Preço de Venda do empreendedor será o menor valor entre o preço de lance, somado à diferença entre UBP's original e de referência, e o Custo Marginal do Leilão (valor correspondente ao maior valor de lance, para os produtos hidro e termo, dentre os lotes contratados no leilão).
} 
Em linhas gerais, a análise dos resultados dos três leilões de energia nova realizados em 2005 e 2006 mostram uma tendência de crescimento da participação da iniciativa privada nos dois últimos leilões relativamente ao primeiro, bem como do quinhão de energia hídrica comercializada frente ao total de energia térmica, que parecem estar associados à elevação do teto para o produto hidro dos 116 [R $\$ / M W h]$, do leilão de dez/05, para os 125 [R $\$ / M W h]$, observado nos dois leilões realizados em 2006.

Entretanto, a ação do MME sobre os preços praticados no leilão ainda parece contribuir para frear um maior interesse do gerador privado pela comercialização de energia no ACR. Nos leilões de dez/05 e de out/06, a quantidade de energia contratado foi inferior à demanda informada pelas distribuidoras. Se considerarmos que a quantidade de energia ofertada era maior do que a quantidade demandada informada pelos distribuidores e que, os proponentes vendedores conheciam de antemão os preços tetos dos produtos hidro e termo, como explicar o índice de atendimento aquém da unidade, senão pela intervenção do organizador na dinâmica do leilão.

De outro lado, se a intervenção sobre os preços afasta o investidor e traz à pauta a discussão acerca da capacidade de suprimento no longo prazo, caminha ao encontro, no curto prazo, de outro dos principais objetivos do novo modelo institucional que é a redução do preço ao consumidor final. No limite, entretanto, a imposição de preços da energia em patamares considerados irreais afasta os investidores e torna a energia mais cara no médio e longo prazos, uma vez que, à medida que os investimentos em expansão não são realizados na velocidade necessária, a energia para atendimento do consumo tem de ser adquirida, em parcelas crescentes, de fontes mais caras. Daí destaca-se que a modicidade tarifária tem de ser lida sob um horizonte de médio e longo prazo, que tome em conta a energia a um preço justo, condizente com a necessidade de expansão de investimentos na formação de uma matriz energética equilibrada e aderente ao balanço energético de longo prazo.

No sentido da modicidade tarifária, destaca-se a mudança sobre o critério de licitação para outorga de novas concessões hidrelétricas, que, no novo modelo, deixa de ser o maior pagamento de UBP e passa a ser a menor tarifa para energia comercializada no ACR. A vinculação da outorga ao proponente que ofereça o maior benefício econômico ao consumidor 
parece ter maior apelo e eficácia, ainda que o UBP pago pelo empreendedor seja, por vias difusas, também revertido para o consumidor ${ }^{41}$.

Que se destaque ainda, o fato dos leilões anteciparem a demanda e a concretização dos contratos de compra e venda de energia, agindo como sinal para novos investimentos, contribuindo para segurança do investidor e para reduzir a percepção de risco sobre o empreendimento, cuja construção já se inicia sob o lastro dos CCEAR's.

Por fim, a obrigatória pulverização dos contratos, firmados bilateralmente entre cada um dos agentes vendedores e cada um dos agentes compradores, reduz ou, ao menos, distribui o risco de inadimplência e o risco de abastecimento para o distribuidor. Adicionalmente, a obrigatoriedade de pulverização dos contratos contribui para uniformização da tarifa ao consumidor final, mesmo que de forma pouco decisiva, dado o número excessivo de variáveis que compõem a estrutura tarifária das concessionárias de distribuição.

Oportuno observar que o conteúdo desta seção deverá ser subsídio para formatação do empreendimento protótipo, que será constituído como base para a análise da qualidade do investimento em empreendimentos de geração de energia hidrelétrica no Brasil. O empreendimento protótipo, formatado no capítulo 5, deve ser representativo das novas concessões outorgadas nos leilões de dezembro de 2005 e outubro de 2006, conforme características apresentadas no (ANEXO A).

\footnotetext{
${ }^{41}$ As novas concessões hídricas ainda devem pagar o UBP de referência, definido pelo poder concedente, para cada aproveitamento a ser concedido. O UBP, portanto, deixou de ser o critério de julgamento do proponente vencedor na licitação de novos aproveitamentos e, por conseqüência, tende a ter um peso menor na composição do preço da energia.
} 


\section{EMPREENDIMENTOS DE GERAÇÃO DE ENERGIA HIDRELÉTRICA: CARACTERÍSTICAS ESTRUTURAIS}

O propósito deste capítulo é discutir os aspectos relacionados à estrutura dos empreendimentos do setor elétrico, com foco na categorização da geração hidrelétrica, buscando construir subsídios para, no capítulo seguinte, perpetrar no desenho do empreendimento protótipo, que será base para análise da qualidade do investimento.

A regulação sobre a exploração dos aproveitamentos hidrelétricos e sobre a comercialização da energia, bem como o largo domínio sobre a tecnologia de produção de energia a partir da fonte hidráulica, conferem ao setor características estruturais bem delineadas e marcantes.

A observação dos projetos empreendidos no segmento de geração hidrelétrica permite reconhecer tendências relacionadas, essencialmente, a:

- Ciclos de formatação, implantação e operacional bem definidos, com atividades características e durações típicas;

- Estrutura contratual; com contratos padrões de concessão, comercialização, construção, operação, uso das instalações de transmissão ou, quando couber, de distribuição;

- Estratégia de investimento e organização societária, assentes nos conceitos de Project Finance e Veiculo de Propósito Específico;

- Equação de fundos e mecanismos para mobilização de recursos para o setor;

- Riscos;

- Parâmetros de Custos de Implantação e Operação.

Este capítulo subdivide-se em três seções: (i) a primeira traz a descrição dos ciclos característicos dos empreendimentos hidrelétricos - ciclo de formatação, ciclo de implantação e ciclo operacional; (ii) a segunda apresenta o Project Finance, enquanto estratégia para captação de recursos e identifica principais fontes e mecanismos para provisão de funding para empreendimentos hidrelétricos e (iii) a terceira seção discute os riscos do investimento em geração. 


\subsection{CICLOS DO EMPREENDIMENTO DE GERAÇÃO HIDRELÉTRICA}

Os empreendimentos hidrelétricos respeitam ciclos bem definidos, com durações típicas: ciclo de formatação, ciclo de implantação e ciclo operacional, conforme Figura[4.1]:

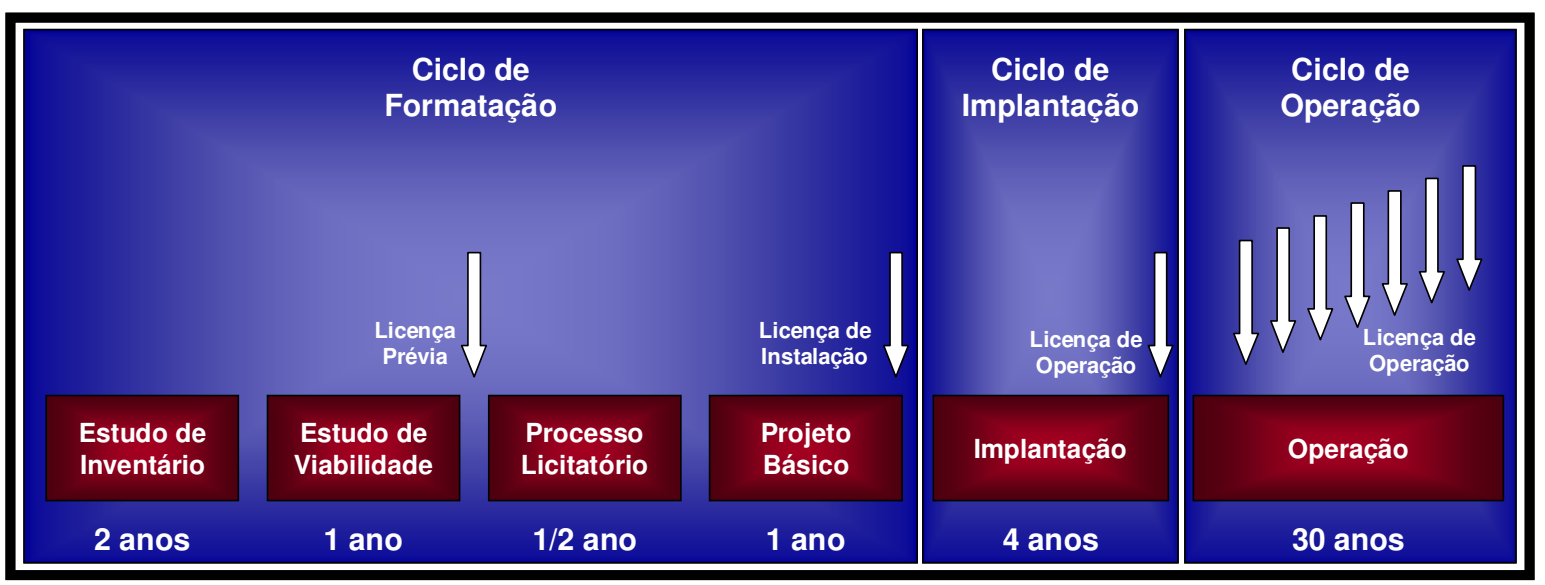

Figura 4.1 - Ciclos do Empreendimento Hidrelétrico Fonte: EPE (2006b)

\subsubsection{Ciclo de Formatação}

A implantação do empreendimento hidrelétrico é precedida por um longo período de estudos e dimensionamento. O período de formatação de um empreendimento hidrelétrico se inicia com o Estudo de Inventário e Estudo de Viabilidade. O Estudo de Inventário visa identificar potenciais aproveitamentos hidrelétricos em determinada bacia hidrográfica e o Estudo de Viabilidade definir o potencial de geração do eixo da barragem e proceder com análise de ordem técnica, energética, financeira e sócio-ambiental que permita inferir sobre a viabilidade do aproveitamento identificado.

Os estudos de inventário e viabilidade duram, aproximadamente, 3 anos. Em média, cerca de dois anos são destinados à realização do Estudo de Inventário da bacia hidrográfica e, cerca de um ano, ao Estudo de Viabilidade do aproveitamento.

De acordo com a lei 393, de 04 de dezembro de 1998, o Inventário constitui a etapa de estudos de engenharia em que se define o potencial hidrelétrico de uma bacia hidrográfica, 
mediante o estudo da divisão de quedas e a definição prévia do aproveitamento ótimo da bacia. O aproveitamento ótimo, por sua vez, é definido pela lei 9.074, de 07 de jul/95, como potencial definido, em sua concepção global, pelo melhor eixo do barramento, arranjo físico geral, nível d'água operativo, reservatório e potência, integrante da alternativa escolhida para divisão de quedas de uma bacia hidrográfica.

O Estudo de Inventário será realizado diretamente pela ANEEL, ou por terceiros, após o processamento do necessário registro. Após o registro, a ANEEL informa ao interessado os prazos para apresentação dos relatórios de andamento dos estudos de inventário, considerados compatíveis com a complexidade da bacia hidrográfica. A obtenção do registro não é exclusividade do primeiro requerente, podendo ser estendido para quantos forem os interessados, desde que estes cumpram com os requisitos impostos, pela ANEEL, para validação dos requerimentos de registro. Depois de examinado e aceito o primeiro estudo de inventário, a ANEEL informa o fato aos demais interessados que possuam registro para estudo da mesma bacia e determina um prazo de 120 dias para a apresentação de seus estudos.

De posse do conjunto de estudos apresentados, a ANEEL conclui com a escolha da divisão de quedas que, ao seu critério, conduza ao aproveitamento ótimo da bacia hidrográfica. Os titulares dos estudos, cujas proposições de aproveitamentos estejam contempladas na configuração de quedas definida pela ANEEL, serão ressarcidos dos respectivos custos incorridos e reconhecidos pela ANEEL se, somente se e quando, o aproveitamento for objeto de programa de licitação de concessões, pelo concessionário vencedor, conforme condições que deverão integrar o edital de licitação da concessão.

Após a definição do conjunto de aproveitamentos que possivelmente serão implantados em determinada bacia hidrográfica, dá-se início à fase de estudo da viabilidade dos potenciais aproveitamentos. O Estudo de Viabilidade tem por objeto o dimensionamento indicativo da alternativa de aproveitamento definida no estudo de inventário, com a estimativa da sua energia firme e assegurada, sua potência instalada e número de unidades de geração, bem como caracterização da topografia local, indicação das condições hidrológicas e meteorológicas da região do aproveitamento, definição preliminar das dimensões do reservatório, das turbinas, das estruturas básicas - barragem, vertedouro, tomada d'água e canal de adução, casa de força, canal de fuga e instalações de transmissão de interesse restrito à central geradora-, estimativa dos custos e do cronograma de implantação da usina e 
apresentação do Estudo de Impacto Ambiental (EIA) e do Relatório de Impacto Ambiental (RIMA).

A requisição de licença prévia ambiental deve ser feita na fase inicial do desenvolvimento do Estudo de Viabilidade frente ao órgão ambiental competente. A gestão necessária para obtenção da licença prévia ambiental, no novo modelo do setor elétrico, é atribuição da EPE.

Como nos processos de inventário, os registros para estudos de viabilidade podem ser obtidos por um ou mais requerentes. Ainda, de modo análogo, após a entrega do Estudo de Viabilidade e a correspondente apreciação e aprovação do primeiro pedido para inclusão do aproveitamento no programa de licitação de concessões, a ANEEL informa o fato aos demais requerentes e determina um prazo de 120 dias para a entrega de seus estudos.

O aproveitamento objeto do estudo é incluído no processo de licitação de novos aproveitamentos e arrematado em leilão, pelo proponente que oferecer o menor preço para energia a ser produzida pela usina e destinada aos consumidores cativos, atendidos pelas concessionárias de distribuição, no ACR. O concessionário, vencedor da licitação, pode acessar o conjunto de estudos de viabilidade depositados na ANEEL para o referido aproveitamento. Apenas o titular do estudo aprovado faz jus ao ressarcimento dos custos incorridos e reconhecidos pela ANEEL, conforme condições que deverão constar do edital de licitação do aproveitamento.

Após o certame para licitação do aproveitamento hidrelétrico, o concessionário e o MME, na qualidade de concedente, firmam contrato de concessão. Os contratos de concessão, com prazo de 35 anos, regulam a exploração, por parte da concessionária, de determinado potencial de energia hidráulica, bem como das instalações de transmissão de interesse restrito à referida central geradora. Entre outros pontos, os contratos de concessão estabelecem:

- Principais características técnicas da usina e das instalações de transmissão de interesse restrito;

- Cronograma de eventos, com indicação dos principais marcos contratuais, entre outros, data para entrega do projeto básico, data de início da concretagem da casa de força, bem como data de descida do rotor, comissionamento e entrada em operação comercial de cada unidade de geração; 
- Definição das obrigações e critérios de conduta para operação técnica e comercial da usina, bem como fixação da Garantia Física, em MW médio, como lastro para os contratos de comercialização de energia e para consumo próprio, nos casos de auto-produção;

- Tratamento contratual para solicitações de ampliação ou modificações da usina; quando autorizadas e aprovadas pela ANEEL, as modificações e ampliações passam a integrar o objeto da concessão;

- Obrigação da Concessionária de desenvolver e entregar o projeto básico da usina, respeitando as principais diretrizes extraídas do Estudo de Viabilidade do aproveitamento e reproduzidas no contrato de concessão;

- Obrigação de pagamento do UBP e estabelecimento do seu critério de atualização monetária;

- Pagamento dos encargos setoriais: taxa de fiscalização ANEEL, taxa de pesquisa e desenvolvimento, compensação financeira pelo uso dos recursos hídricos, cotas da conta de consumo de combustíveis, taxas de utilização dos sistemas de transmissão e, se couber, de distribuição;

- Obrigação de ressarcimento dos custos de desenvolvimento já incorridos: estudos de inventário e viabilidade e custos para obtenção da licença prévia ambiental;

- Regras e diretrizes para exploração do aproveitamento, com respeito à segurança, aos tratamentos das questões técnicas, comerciais e sócios ambientais;

- Obrigação de depósito de Garantia de Cumprimento das Obrigações Contratuais, equivalente a aproximadamente $10 \%$ do custo de implantação informado à ANEEL, vigente até três meses contados do início da entrada em operação comercial da última unidade geradora;

- Prerrogativa ao concessionário para liberação das áreas de terra necessárias para implantação da UHE. Se solicitada, a ANEEL interfere, com a declaração de utilidade pública dos terrenos, para fins de desapropriação, ficando a concessionária responsável pela efetivação da liberação e pagamento das indenizações;

- Permissão ao concessionário, para servir-se dos direitos emergentes da concessão como garantia de contratos de financiamento, com a ressalva de que a eventual execução da garantia não comprometa a continuidade da operação da usina. Os direitos emergentes da concessão consideram os contratos de compra e venda da energia, os direitos de exploração e as instalações da usina;

- Multas e penalidades; 
- Regras da fiscalização da exploração pela ANEEL;

- Condições para intervenção na concessão;

- Condições para transferência da concessão ou alteração societária.

Após a outorga da concessão, os concessionários, ou empreendedores, iniciam o desenvolvimento do projeto básico. A deposição do projeto básico na ANEEL deve ocorrer aproximadamente um ano após a licitação da concessão. O projeto básico da usina deverá trazer o detalhamento das características técnicas das obras civis e dos equipamentos eletromecânicos e da elaboração de suas correspondentes especificações técnicas.

Paralelamente ao desenvolvimento do projeto básico, o empreendedor busca cumprir as requisições ambientais para obtenção da licença ambiental de instalação. A licença de instalação constitui a segunda fase do licenciamento, etapa em que o empreendedor submete à análise da autoridade ambiental os projetos de controle ambiental, onde são identificados e descritos os programas a serem implementados para efetivação das recomendações apresentadas no EIA/RIMA e atender às exigências e condicionantes fixadas pelo órgão licenciador.

O ciclo de implantação do empreendimento somente pode ser iniciado após a apreciação do projeto básico da usina pela ANEEL e obtenção, pelo empreendedor, da licença de instalação.

\subsubsection{Ciclo de Implantação}

O ciclo de implantação tem duração aproximada de 4 anos. Em geral, pode-se considerar que, para usinas com capacidade instalada superior a $30 \mathrm{MW}$, são necessários ao menos três anos para colocação da primeira unidade de geração em operação.

Durante o ciclo de implantação, com base no projeto básico da usina, desenvolve-se o projeto executivo, que deve conter o detalhamento das obras civis e dos equipamentos eletromecânicos que compõem a planta geradora, respeitando um prazo de defasagem com o cronograma de implantação, que, usualmente, gira em torno de 60 a 90 dias. 
Durante o ciclo de implantação vigora o contrato de implantação firmado entre empreendedor e fornecedores de serviços de engenharia e construção e equipamentos eletromecânicos. Usualmente, o empreendedor firma um único contrato de implantação com um consórcio formado por empresas de engenharia e fabricantes de equipamentos. Atualmente, contratos na modalidade "chave na mão" ou turn key são mais comuns.

Os contratos do tipo turn key são assim denominados, para designar a extensão do escopo da entidade contratada, a quem fica atribuída a responsabilidade por entregar o empreendimento ao contratante pronto para operação. Usualmente, os contratos tipo turn key estabelecem data para entrega e fixam o preço global do contrato, respeitando-se um regime de pagamentos mensais, vinculado ao cumprimento de um cronograma de eventos também definidos contratualmente.

Nos contratos do tipo turn key com preço global, o consórcio construtor assume uma porção maior do risco de construção, se comparada à posição do construtor nos tradicionais contratos por Preço Unitário ou por Administração. Na modalidade turn key, o consórcio construtor assume a responsabilidade pelo desenvolvimento do projeto da planta de geração, da execução das obras civis, da fabricação, fornecimento e montagem dos equipamentos eletromecânicos e pelo comissionamento da usina. A atribuição do consórcio construtor, sem prejuízo do prazo de responsabilidade pela construção, se extingue na entrega da usina já comissionada, em condições de operar.

Como o escopo do consórcio construtor abarca as atividades de dimensionamento e desenvolvimento de projeto, quaisquer distorções que vierem a surgir entre valores planejados e realizados, associadas aos quantitativos do projeto, preços de insumos e serviços e prazos representam, em geral, ônus ou benefício para o consórcio construtor, ficando o empreendedor contratante, ao menos, em teoria, protegido dos riscos de construção.

Os contratos na modalidade turn key tornaram-se comuns nos projetos de implantação de empreendimentos hidrelétricos. Não obstante os preços dos contratos firmados nesta modalidade tendam a resultar superior aos preços que seriam praticados em contratos do tipo unitário ou por administração, dada a necessidade de cobertura para o risco ao qual se expõe o consórcio construtor, ao que parece, contratos desta natureza tornar-se-ão uma constante em empreendimentos do setor elétrico. À medida que transferem ou, ao menos, mitigam o risco 
de construção, compartilhando-o com entidades que, por definição, têm maiores condições ou grau de especialização para assumi-los, os contratos tipo turn key são vistos de forma positiva por investidores e credores.

No período de implantação, o empreendedor deve reunir elevada massa de recursos para fazer frente, entre outros itens, ao regime de pagamentos estabelecidos no contrato de implantação firmado com o consórcio construtor. Os contratos de implantação com o consórcio construtor, usualmente, e assim será admitido quando do desenho do empreendimento protótipo, incluirão as contas associadas ao projeto de engenharia, gerenciamento e planejamento da execução, à mobilização para produção, aos custos associados às obras civis, aí abarcados, instalações e obras auxiliares, desmatamento, serviços de terraplenagem, escavação a céu aberto e subterrânea de solo e rocha, concretagem das estruturas principais barragem, vertedouro, estrutura de tomada d’água, canal de adução, casa de força, condutos forçados, bem como custos dos serviços eletromecânicos, tais quais montagem de comportas, unidades de geração, pontes rolantes, subestação e linha de transmissão de interesse restrito à central geradora. Adicionalmente, integram o plano de contas da implantação do empreendimento custos de desenvolvimento associados à estruturação e autorizações legais, fiscalização de obras, seguros de construção, garantias dos contratos de comercialização de energia, custo financeiros e sócios ambientais.

Os recursos para fazer frente aos dispêndios do período de implantação são provindos de montantes aportados pelos próprios empreendedores e, comumente, por terceiros que participam do financiamento do empreendimento. A questão do financiamento de empreendimentos de geração hidrelétrica é tema que demanda discussão particular e que será tratado ainda neste capítulo, em seção posterior, dadas as dimensões dos montantes envolvidos na fase de implantação e aos longos prazos de construção, que reclamam crédito em condições de todo específicas, no tocante, essencialmente, aos prazos de carência, amortização e ao regime de pagamento de encargos durante a construção.

O início do ciclo operacional caracteriza-se pela entrada em operação comercial da primeira unidade geradora. Um dos principais marcos dentro do cronograma de implantação de um empreendimento hidrelétrico é o início do enchimento do lago, que só ocorre após a obtenção da licença de operação. É comum que se tenha um período de sobreposição entre os ciclos de implantação e operacional até a entrada em operação da totalidade das unidades de geração. 


\subsubsection{Ciclo Operacional}

O ciclo operacional do empreendimento hidrelétrico, para efeito da análise da qualidade do investimento será de aproximadamente 30 anos, de forma que a soma dos períodos de desenvolvimento de projeto básico, implantação e operação da usina totalizem os 35 anos, definido como prazo do contrato de concessão entre o empreendedor e o Ministério das Minas e Energia. Não obstante, o ciclo operacional referencial de usinas hidrelétrica se estenda por aproximadamente 50 anos, após o que, se fazem necessárias intervenções em modernização do ativo para manutenção da capacidade e eficiência na geração.

A operação da usina pode ser conduzida pelo próprio empreendedor, caso seja este seu campo de especialização, ou pode ser tarefa delegada, pelo empreendedor, a um terceiro, mediante um contrato de operação e manutenção. De forma geral, se associam ao ciclo operacional, riscos de natureza comercial e técnica baixos e, por conseqüência, fluxos de caixa de pequena flutuação.

No ciclo operacional, o plano de contas do empreendedor passa a constituir-se de: contas gerais da administração, custos associados diretamente à manutenção e conservação, seguros e garantias, programa de ações sócio ambientais, custos financeiros, encargos setoriais, impostos sobre faturamento e movimentação financeira, pagamento do uso do bem público, pagamento das tarifas de uso do sistema de transmissão ou, quando couber, do sistema de distribuição.

Em geral, a atividade de geração de energia elétrica é caracterizada por altos índices de geração de caixa operacional, dado que apenas uma pequena porção do faturamento destina-se à cobertura dos custos de operação e manutenção, por natureza, baixos. Assim como observado nos empreendimentos intensivos em capital, a maior parcela do faturamento é destinada ao pagamento das obrigações de natureza financeira, amortização e juros da dívida, e à remuneração dos recursos do empreendedor imobilizados no empreendimento. 
Ao longo do ciclo operacional da usina, a licença de operação, que dispara o enchimento do lago, deve ser renovada, sempre em prazos não superiores a quatro anos.

Adicionalmente, ao final do contrato de concessão, o direito de exploração, bem como os ativos e instalações vinculados ao aproveitamento revertem para o poder concedente. Ao concessionário caberá indenização, no valor das parcelas não depreciadas dos ativos revertidos. Após o término do contrato de concessão, o poder concedente pode prorrogar o contrato ou promover nova licitação da concessão do direito de exploração do aproveitamento. 


\subsection{ESTRATÉGIA DE INVESTIMENTO E MECANISMOS DE MOBILIZAÇÃO DE FUNDOS}

\subsubsection{Project Finance como Estratégia de Investimento ${ }^{42}$}

Os contratos de concessão para exploração de aproveitamento hidrelétrico estabelecem a permissão para que os empreendedores sirvam-se dos direitos emergentes da concessão, como lastro para captação dos recursos necessários para implantação da usina. Os direitos emergentes da concessão incluem os contratos de compra e venda de energia, o direito de exploração do aproveitamento e os ativos associados à usina. A permissão para utilização do próprio ativo físico, com os contratos de comercialização a ele imbricados, como garantia de operações de financiamento, tornam a atividade de geração de energia hidrelétrica, ambiente propício para estruturação de um Project Finance.

O Project Finance pode ser definido como estratégia de investimento, aplicada aos empreendimentos com capacidade de auto-sustentação financeira, com o objetivo de buscar recursos para atender a demanda por investimentos para sua implantação. No Project Finance, o investidor ou financiador enxerga, como contrapartida para os recursos que imobiliza, apenas a capacidade de geração de renda do empreendimento, tomando como garantia exclusivamente os ativos associados ao próprio projeto e o fluxo de renda gerado no ambiente do empreendimento.

A diferença primordial entre o Project Finance e as formas tradicionais de captação corporativa é o fato da operação, no primeiro, estar restrita ao ambiente de um único projeto. Nas operações tradicionais de captação corporativa, o investidor ou financiador, que empresta recursos à empresa, geralmente o faz baseado na classificação do risco de crédito da empresa tomadora, tendo em vista todo o universo de seu portfólio de negócios, enquanto que, no Project Finance, a análise tem seu foco na qualidade econômica da operação isolada para o qual o recurso pleiteado se destina.

\footnotetext{
${ }^{42}$ Com base em ROCHA LIMA JR. (1999a)
} 
Na captação corporativa tradicional, o provedor de recursos baliza sua decisão pela análise da qualidade da situação financeira atual e das perspectivas de resultado futuro da empresa pleiteante, do histórico de comportamento financeiro e relacionamento com a instituição provedora dos fundos, da posição de mercado da empresa e de seu tamanho relativamente aos montantes envolvidos na operação de crédito pleiteada.

Nestes casos, o risco, do ponto de vista do provedor de recursos, está comumente associado à capacidade da empresa pleiteante de gerar recursos no universo de seu portfólio de negócios para fazer frente aos compromissos financeiros assumidos, de forma que os recursos para pagamento do principal e do serviço da dívida contraída não necessariamente serão gerados nas atividades para as quais foram aplicados. Adicionalmente, como garantia para os recursos emprestados pode ser oferecido, como contrapartida, ao provedor de recursos, o direito de acesso aos ativos de propriedade da empresa e ao patrimônio de seus acionistas, por meio da firma de garantias reais - hipoteca, penhor ou alienação fiduciária envolvendo bens de propriedade da empresa - ou garantias pessoais - aval ou fiança -, para o caso de não cumprimento das obrigações financeiras assumidas. Enfim, os provedores de recursos expõem-se ao risco empresa e não ao risco projeto.

No Project Finance, os provedores de recursos tomam, essencialmente, risco projeto e enxergam como garantia para os recursos aplicados primordialmente o fluxo de caixa do projeto e, em posição secundária, os ativos associados diretamente ao próprio projeto que, a depender da natureza do empreendimento, podem vir a ter pequena ou nenhuma liquidez. Nas operações de Project Finance, os provedores de recursos, tradicionalmente, não têm direito de acesso ao patrimônio dos empreendedores, em caso do não cumprimento das obrigações financeiras assumidas.

Os empreendimentos formatados em Project Finance são usualmente classificados, pela prática de mercado, em duas modalidades que se diferenciam pelo grau de solidariedade dos sócios, ou seja, pelo grau de acesso dos investidores e financiadores ao patrimônio dos sócios controladores da Sociedade de Propósito Específico (SPE), em caso de não cumprimento, por parte destes, dos compromissos contratuais financeiros firmados: recurso limitado (limited recourse) e sem recurso (non-recourse). A título de exemplo, a busca por recursos segundo sistemas tradicionais de captação está costumeiramente associada à oferta de garantias 
solidárias, com direito pleno de recurso ao patrimônio dos sócios controladores (full recourse).

A estrutura de garantias em uma operação non recourse configura a essência do conceito Project Finance, onde o empreendimento assume personalidade jurídica própria e totalmente independente dos demais negócios de seus sócios. Em empreendimentos formatados desta maneira, as garantias aos recursos aportados no empreendimento estão vinculadas ao próprio projeto.

Estas garantias podem estar caracterizadas, por exemplo, pelos contratos comerciais do empreendedor, pelos ativos gerados no próprio projeto, por hipoteca de bens e imóveis vinculados ao empreendimento, pela caução das ações do empreendimento e por instrumentos que garantam ao credor prioridade de retorno frente aos sócios e assegurem a capacidade do projeto de pagamento de sua dívida (covenants) - como a obrigação de constituição de conta reserva para pagamento da dívida, restrições à distribuição de dividendos e ao pagamento de juros sobre capital próprio ou, limitações ao endividamento da SPE.

Arranjos financeiros desta natureza são raros e estão associados a custos de financiamento altos, uma vez que as taxas refletem a não solidariedade do sócio e, conseqüentemente, a necessidade de cobertura integral dos riscos associados ao empreendimento, principalmente daqueles relacionados à sua implantação, dado que os instrumentos de garantia citados só ganham validade após o término da construção, quando o empreendimento atinge capacidade de gerar renda.

O Project Finance limited recourse pode ser entendido como alternativa intermediária entre as modalidades full recourse e non recourse. Neste arranjo, os contratos podem admitir, durante um prazo determinado ou toda a vida do projeto, algum direito de recurso dos credores ao patrimônio dos sócios (FINNERTY, 1998). A configuração mais comum de empreendimentos formatados segundo esta lógica é aquela em que os sócios, ou empresas contratadas para prestação dos serviços de construção, oferecem garantias reais ou pessoais ao credor, enquanto durar o período de construção, onde o risco é acentuado devido à incapacidade do projeto gerar renda e, por consequiência, ao baixo valor dos ativos até então constituídos. Assim, as garantias oferecidas pelos sócios ou terceiros podem ter prazo determinado, sendo, costumeiramente, substituídas por garantias vinculadas ao próprio 
projeto após o período de construção. Como alternativa, pode-se recorrer a empréstimos do tipo ponte (full recourse) para o período de implantação do projeto que, após a construção, dada a redução da percepção do risco sobre o projeto, são liquidados com recursos captados via contratação de financiamento de longo prazo ou pela emissão de títulos no mercado, em condições non-recourse. As garantias de terceiros adicionais ao próprio projeto reduzem o risco percebido e, conseqüentemente permitem tornar menor o custo da captação de fundos, relativamente ao que seria obtido em uma operação integralmente non-recourse.

Em função da operação veicular restrita ao ambiente do próprio projeto, os empreendimentos em Project Finance são usualmente desenvolvidos de maneira a isolar as transações vinculadas ao empreendimento das demais operações envolvendo seus empreendedores, através de veículos denominados Sociedades de Propósito Específico (SPE's). BORGES (1999) define as SPE's como "sociedades criadas exclusivamente para dar existência legal a um projeto e ao seu fluxo de caixa. O risco dos investidores e financiadores é limitado à qualidade dos créditos de que a SPE é titular”.

Conforme descreve ALENCAR (1998), a SPE é criada pelo empreendedor para segregar a operação ou empreendimento alvo, de seus riscos sistêmicos. Segundo o autor, cria-se a SPE para se isolar os riscos associados às outras atividades do originador, da SPE, entendida com uma operação discreta com seu contorno de riscos contido no seu próprio desempenho, não no da organização que a desenvolve.

Os empreendimentos desenvolvidos em Project Finance, principalmente no setor de infraestrutura, apresentam relativa segurança quanto à geração de renda futura, seja pela característica de monopólio do serviço ou pela pré-existência de contratos de compra e venda de longo prazo bem como, em muitos casos, também, contratos pré-firmados com fornecedores de produtos e serviços para os ciclos de implantação e operacional do empreendimento, que permitem projetar com segurança sua estrutura de custos.

A relativa segurança na construção de cenários para a situação de caixa futura do projeto, combinada à blindagem do empreendimento, na estrutura de veículo de propósito específico que, mitiga riscos de contaminação do projeto por negócios dos originadores estranhos à SPE, concorre para que provedores de recursos atribuam maior segurança ao empreendimento e, 
por conseqüência, condições e custos mais atrativos aos empreendedores, para os recursos emprestados ao projeto.

A adoção do Project Finance, como estratégia de investimentos em empreendimentos hidrelétricos, exige a acomodação de um grande número de agentes ao redor da SPE, que interagem por força de obrigações contratuais e dos fluxos de transferência de recursos ao longo dos ciclos de implantação e operacional do empreendimento. A estrutura genérica de um Project Finance em empreendimento do setor elétrico, que leva em conta endividamento proveniente de financiamento direto e emissão de títulos de dívida, assume a configuração da Figura[4.2], onde os fluxos identificados pela cor alaranjada fazem referência ao ciclo de implantação e os azuis ao ciclo operacional.

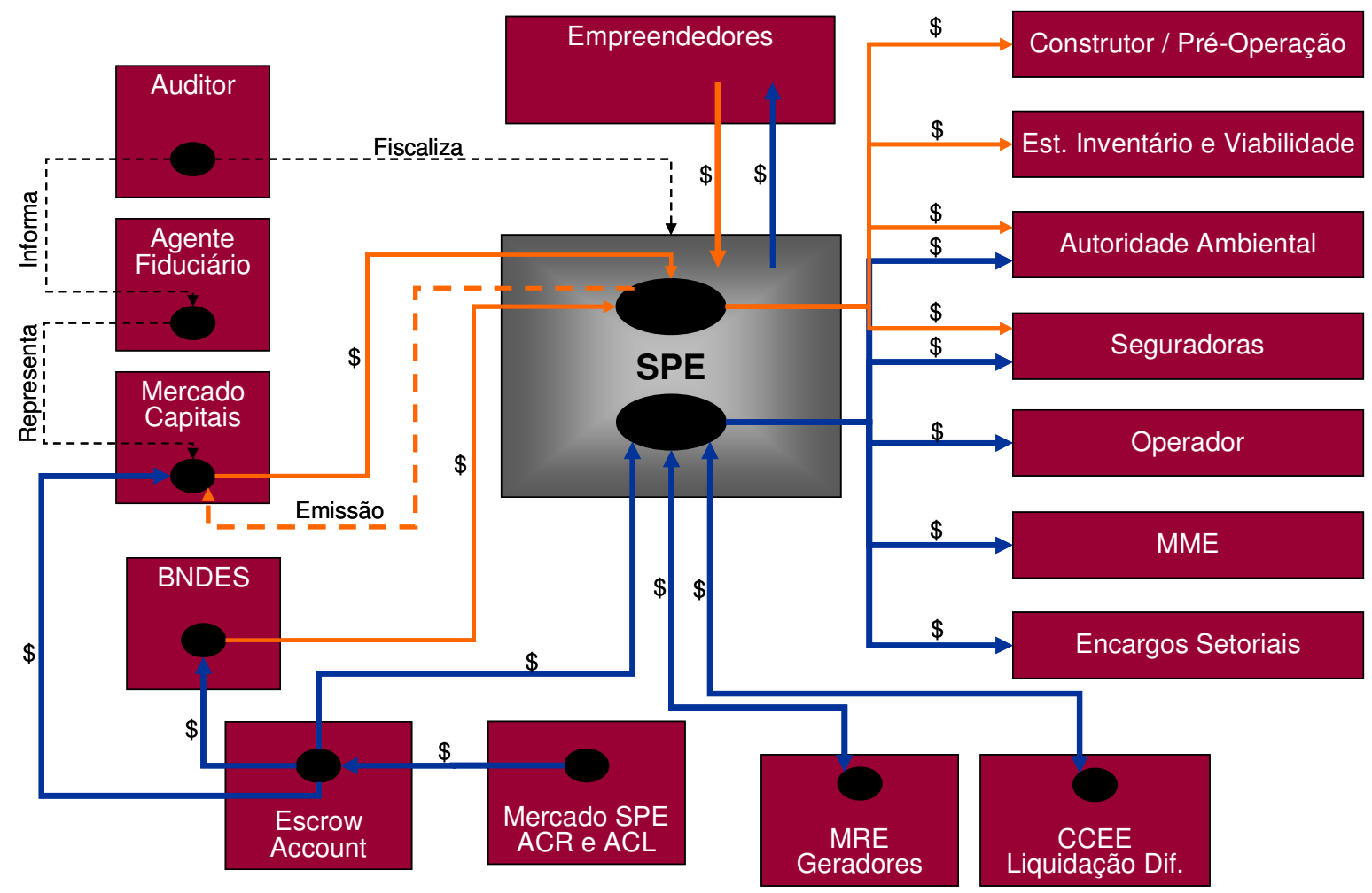

Figura 4.2 - Estrutura Genérica Project Finance - Empreendimento Hidrelétrico Adaptado de BONOMI; MALVESSI (2002)

Na Figura[4.2], a implantação e operação do empreendimento hidrelétrico ocorrem no ambiente da SPE. Os recursos para implantação do empreendimento são providos por três fontes, via mecanismos distintos: (i) os empreendedores, na qualidade de acionistas e controladores da SPE, aportam recursos na SPE, via conta de capital ou dívida subordinada; (ii) instituições financeiras destinam recursos para SPE, pela via do financiamento direto e 
(iii) investidores, pulverizados no mercado de capitais, completam a equação de fundos do ciclo de implantação, através da subscrição de títulos de dívida a serem emitidos pela SPE.

Figuram a estrutura apresentada também, no que se refere à estrutura para mobilização de fundos para sustentar a implantação, o Auditor e o Agente Fiduciário na intermediação das relações entre credores e a SPE. O Auditor fiscaliza a disposição e utilização de recursos, durante os ciclos de implantação e operacional, emitindo relatórios de andamento ao Agente Fiduciário. O Agente Fiduciário representa o conjunto de investidores nos títulos em todas as relações com a SPE.

O retângulo com a denominação Escrow Account faz menção aos serviços de administração de conta de centralização de receitas. A instituição recolhe e administra os recursos provindos dos contratos de venda de energia firmados pela SPE, segundo uma ordenação de pagamentos, que prioriza a devolução e remuneração de recursos de terceiros, frente à cobertura das contas de operação da SPE e ao retorno dos empreendedores.

O regime de ingresso de recursos na SPE busca seguir o cronograma de desembolsos do empreendimento, observadas restrições associadas à periodicidade das liberações dos contratos de financiamento e de integralização de títulos de dívida. Em geral, recursos providos pelos empreendedores ingressam na SPE em momento anterior aos recursos de terceiros. Tal prática é preferida por credores, pois denota comprometimento do empreendedor com o desenvolvimento do empreendimento. Por vezes, a antecipação da contrapartida dos empreendedores é exigida em contratos de financiamento de longo prazo, por exemplo, como requisito para que o crédito ocorra nas condições de um Project Finance non recourse, ou, que sejam dispensadas garantias de terceiros durante o período de implantação do empreendimento.

Na Figura[4.2], os recursos mobilizados durante a implantação são utilizados para fazer frente ao fluxo de obrigações com o consórcio construtor, para ressarcir os executores dos estudos de inventário e viabilidade e desenvolver o projeto básico da usina, para contratação de seguros e garantias, por ocasião da implantação e por obrigação dos contratos de compra e venda de energia, bem como para cobertura de contas pré-operacionais como, custos de desenvolvimento e estruturação, de natureza técnica financeira, jurídica e sócio-ambiental. 
O período de implantação se estende por 3 a 4 anos. O longo período para início de geração de caixa, combinado ao fato de que a SPE deve manter-se presa ao seu único propósito, faz com que as operações financeiras desenhadas para empreendimentos hidrelétricos necessitem prazos de carência extensos, casados com o programa de entrada em operação comercial da usina.

Durante o período de implantação, a prática, ao menos dos programas de financiamento a empreendimentos de geração de energia elétrica, é iniciar a amortização do principal e o pagamento de juros apenas após a entrada em operação comercial da usina, capitalizando os juros durante a construção ao saldo devedor da operação ou, ainda, financiando os juros durante a construção, na hipótese em que seu pagamento, durante este período, seja exigido.

$\mathrm{Na}$ captação de recursos via emissão, os longos períodos de implantação e de carência de principal podem tornar o produto de investimento pouco atrativo, caso não seja formatado nenhum vetor de remuneração para o título durante o longo período de implantação. Assim como se pratica nas operações de financiamento direto, onde os juros durante a construção, quando pagos, são incluídos no montante financiado, os recursos necessários para cobrir o fluxo de remuneração do título de dívida, durante o período de implantação, podem integrar o montante da emissão.

Alternativamente, o empreendedor pode lançar mão da emissão como mecanismo para alterar a composição de sua dívida, ao final do período de implantação. Recursos captados via emissão de títulos ao final da implantação poderiam, por exemplo, ser mobilizados para rolagem de dívida contraída no início do ciclo de implantação. Em teoria, o custo da nova dívida seria menor, já que não mais refletiria a necessidade de cobertura dos custos de construção.

Nesta situação, estes títulos poderiam ser formatados sem carência de principal e juros, tornando a hipótese de investimento nos títulos mais atrativa, dado que o período de operação do empreendimento já teria iniciado. O risco do investidor, que adquire títulos de dívida da SPE ao final da implantação, ficaria tão mais mitigado quanto maior a parcela da energia assegurada do empreendimento empenhada em contratos de compra e venda de energia de longo prazo, essencialmente aqueles firmados no ACR. 
A entrada do investidor privado não especialista ao final da construção pode ocorrer, ainda, pela compra de recebíveis de entidades bancárias, que promovam a securitização dos financiamentos a empreendimentos ou a portfólio de empreendimentos de infra-estrutura de sua carteira, ou, pelo próprio empreendedor, que capta recursos junto ao investidor institucional para quitar financiamento bancário, quitar mútuo de um ou mais acionistas com a própria SPE ou comprar a posição acionária de investidores cuja estratégia seja participar apenas da implantação do empreendimento.

A Figura[4.2] traz ainda os fluxos de obrigações da SPE durante o período operacional. Na seqüência indicada, os recursos provenientes dos contratos de venda da energia produzida ingressariam em uma conta segregada, administrada por uma instituição financeira contratada para tal, cuja atribuição seria priorizar o pagamento das obrigações frente aos credores, destinando o montante restante para a SPE.

Os recursos que, por vez, ingressariam na SPE seriam destinados ao pagamento das contas de operação e manutenção, seguros, despesas administrativas, programas ambientais, encargos setoriais, bem como liquidação de posição devedora frente aos agentes do setor, no âmbito do MRE e do mercado de curto prazo. Somente os recursos restantes, retornariam ao empreendedor por meio de distribuição de dividendos ou resgate e remuneração de série de títulos subordinados de emissão privada, para carteira do próprio empreendedor, caso esta fosse uma das alternativas utilizadas para o ingresso dos recursos dos acionistas da SPE.

No restante desta seção serão identificados e descritos, com maior profundidade, os principais mecanismos para mobilização de fundos para o desenvolvimento de empreendimentos de geração de energia elétrica. Como observado nesta seção, a participação de investidores não especialistas no setor está vinculada à criação de instrumentos de investimento que permitam a alocação dos riscos de implantação e operação, segundo uma perspectiva compatível com o padrão de seu binômio Rentabilidade x Riscos.

De forma genérica, a participação de investidores não especialistas em empreendimentos do setor pode se dar de forma direta ou indireta, através da aquisição de posição acionária ou credora, ao longo dos ciclos de implantação e operação do empreendimento. 


\subsubsection{Fontes e Mecanismos de Funding}

\subsubsection{Participação Acionária}

O aporte de recursos na SPE pela via da participação acionária pressupõe a assunção plena dos riscos do empreendimento por parte do investidor. $\mathrm{O}$ agente que adquire posição acionária na SPE divide com o empreendedor, os riscos de natureza comercial, técnica e operacional, bem como de solvência financeira da nova empresa. Em resumo, os investidores compartilham do binômio Rentabilidade x Risco do empreendedor.

Como a participação acionária implica em assunção plena dos riscos, os acionistas de empreendimentos de geração de energia hidrelétrica são comumente empresas habituadas ao investimento no setor, que podem ter neste o seu objeto social ou que, através deste, alavancam sua atividade fim, como empresas do setor de engenharia e construção ou grandes consumidores de energia.

Adicionalmente, o investimento em ações de empresas criadas exclusivamente para exploração hidrelétrica pode integrar o portfólio de instituições cujo objetivo é o investimento em participações, como companhias ou fundos de private eqüity, ou as divisões de investimentos de bancos de desenvolvimento e bancos comerciais.

Os recursos de investidores institucionais não especialistas podem ser derivados para empreendimentos do setor, por veículos intermediários, como Fundos de Investimento em Infra-estrutura ou Fundos de Investimento em Participações (FIP's) que, atualmente, constitui um dos principais canais para o investimento não especialista em empreendimentos do setor elétrico.

Os FIP's, ao reunirem competência para decidir sobre investimentos e gerenciar portfólio de investimentos no setor elétrico, aglutinam recursos, principalmente oriundos de investidores institucionais, como os fundos de previdência, para aplicação em empreendimentos do setor.

Conforme dispõe a instrução CVM n ${ }^{0}$ 391, de 16 de julho de 2003: 
O FIP, constituído sob a forma de condomínio fechado, é uma comunhão de recursos destinados à aquisição de ações, debêntures, bônus de subscrição, ou outros títulos e valores mobiliários conversíveis ou permutáveis em ações de emissão de companhias, abertas ou fechadas, participando do processo decisório da companhia investida, com efetiva influência na definição de sua política estratégica e na sua gestão, notadamente através da indicação de membros do Conselho de Administração.

\subsubsection{Financiamento Direto}

Além dos recursos próprios dos acionistas da SPE, a equação de fundos para implantação do empreendimento hidrelétrico compõe-se adicionalmente, e em geral de forma preponderante, por recursos de terceiros. Os recursos de terceiros podem ingressar na SPE, pela via do financiamento direto ou pela emissão de títulos de dívida. Neste tópico serão abordadas as fontes que, entende-se, possam destinar recursos aos empreendimentos hidrelétricos por meio de financiamento direto.

\section{$\underline{\text { BNDES }}$}

Atualmente, o BNDES figura como principal fonte de recursos de longo prazo, em moeda local, para empreendimentos do setor elétrico.

A participação do BNDES atinge, como limite superior, aproximadamente $80 \%$ dos itens financiáveis do orçamento de implantação ${ }^{43}$. As operações podem ocorrer na modalidade direta, quando são desenvolvidas diretamente entre o BNDES e a empresa beneficiada, ou indireta, quando os recursos são transferidos à empresa beneficiada através de agentes repassadores, que compartilham do risco da operação com o BNDES. Normalmente, as operações são firmadas segundo uma combinação das modalidades direta e indireta.

O custo da operação é composto por TJLP (Taxa de Juros de Longo Prazo)+ spread BNDES nas operações diretas e TJLP + spread BNDES + spread do agente, nas operações indiretas.

${ }^{43}$ Em empreendimentos do setor elétrico, $80 \%$ dos itens financiáveis do orçamento de implantação equivalem a aproximadamente $65 \%$ a $70 \%$ do orçamento total de implantação, na hipótese em que os equipamentos eletromecânicos sejam de fabricação nacional. 
O período de carência de principal e juros usualmente se estende por até 6 meses após a entrada em operação comercial da usina, período em que os juros devidos podem ser capitalizados no saldo devedor ou pagos, integrando assim o montante financiado. O prazo total de amortização varia entre 12 e 16 anos e o fluxo de pagamentos de principal respeita o Sistema de Amortizações Constantes - SAC.

O pacote de garantias exigido pelo banco contempla:

Durante todo o período de financiamento:

- Penhor de ações de emissão da empresa beneficiada.

- Penhor dos direitos emergentes da concessão

Durante o período de implantação:

- Fiança

- Seguro-Garantia de execução das obras

Durante o período de amortização

- Contrato de cessão e vinculação de receitas

Ademais das garantias, a empresa beneficiada deverá, ao longo de todo o período de amortização, manter um Índice de Cobertura do Serviço da Dívida - ICSD de, no mínimo, 1,3. O ICSD representa a relação entre o Caixa Disponível para Pagamento do Serviço da Dívida ${ }^{44}$ e o Serviço da Dívida.

\section{$\underline{\text { Bancos Comerciais }}$}

Os bancos comerciais atuam de forma intensiva na estruturação de operações para captação de recursos de longo prazo. Mais do que a provisão de recursos propriamente dita que, no setor elétrico, reclama prazos normalmente não condizentes com os destinos de investimentos de bancos comerciais, estes desempenham papel de consultores, ou facilitadores, no processo de captação de recursos de longo prazo para projetos de infra-estrutura.

\footnotetext{
${ }^{44}$ Caixa Disponível para Pagamento do Serviço da Dívida:

(+) Disponibilidade de caixa do período imediatamente anterior;

(+) EBITDA;

(-) Imposto de Renda;

(-) Contribuição Social sobre o Lucro Líquido;

(+/-) Variação do Capital de Giro.
} 
A atuação dos bancos pode contemplar, isolada ou cumulativamente:

- concessão de financiamento de longo prazo, isoladamente ou através de sindicato de bancos;

- intermediação na relação entre empreendedor e bancos de desenvolvimento ou investidores institucionais;

- repasse de recursos do BNDES, instituições multilaterais e Agências de Crédito à Exportação;

- serviços de hedge de taxa de juros e câmbio para proteção dos descasamentos verificados entre o fluxo de ingressos e o fluxo de saídas do empreendimento;

- provisão de financiamento do tipo ponte ou capital de giro, para cobertura dos déficits de caixa verificados pelo descasamento entre o fluxo de ingressos de recursos de longo prazo e o cronograma de desembolsos do empreendimento;

- estruturação e colocação de títulos de dívida no mercado de capitais;

- agente fiduciário, como representante dos interesses de um grupo de credores na gestão financeira da SPE;

- serviços de escrow account, como instrumento para centralização e vinculação das receitas operacionais do projeto, promovendo a hierarquização no pagamento das obrigações da SPE;

- concessão de garantia, quando a operação pede coobrigação de terceiros para com o pagamento dos recursos emprestados.

\section{Agências de Crédito à Exportação (ECA - Export Credit Agencies)}

As ECA's são agências que apóiam as exportações de bens e serviços dos países onde estão sediadas. Estas agências concedem financiamentos de longo prazo aos importadores de bens e serviços fabricados no seu país de origem, como mecanismo de fomento à indústria exportadora. As principais ECA's operam segundo procedimentos definidos no âmbito da Organisation for Economic Co-operation and Development (OECD).

O papel disciplinador da OECD tem como propósito nivelar a atuação e as condições do apoio financeiro destas instituições às operações de comércio bilateral, reduzindo subsídios 
financeiros e distorções no comércio exterior, com vistas a manter a competição entre países estrita ao preço e qualidade dos produtos transacionados.

De modo geral, a participação das ECA's requisitam a garantia de uma pequena parcela do risco comercial por parte de instituições de seguro de crédito à exportação ou bancos comerciais, localizados em seu país de origem e no país do importador.

A parcela financiada é usualmente limitada em $85 \%$ do valor da exportação. Os prazos das operações costumam estender-se por aproximadamente 10 anos, com períodos de carência do principal flexíveis à capacidade de pagamento do tomador. O encaixe do financiamento ocorre conforme o cronograma de desembolsos estabelecido entre o exportador e o importador e as parcelas de amortização costumam respeitar periodicidade semestral. Os custos do financiamento contemplam, além dos juros, taxas de seguro e estruturação pagas pelo tomador no ato da contratação e, usualmente, taxa sobre o saldo reservado não desembolsado (commitment fee) ao longo do período de liberação do crédito contratado. Os juros podem ser fixos ou variáveis, nesta hipótese, comumente, vinculados ao comportamento da $\mathrm{LIBOR}^{45}$ e $\mathrm{CIRR}^{46}$.

Entre as principais Agencias de Crédito à Exportação destacam-se US Eximbank (EUA), BNDES $^{47}$ (Brasil), Hermes (Alemanha), Jexim (Japão), ECGD (Reino Unido), COFACE (França), SACE (Itália), CESCE (Espanha) e FINNVERA (Finlândia).

\section{Organizações Multilaterais}

As agências multilaterais têm como missão promover o desenvolvimento econômico, social e institucional através do suporte financeiro a projetos com potencial para melhoria da

\footnotetext{
${ }^{45}$ London Interbank Offered Rate (LIBOR), taxa de juros utilizada como referência internacional, publicada diariamente, praticada em operações entre instituições financeiras no mercado interbancário londrino.

${ }^{46}$ Commercial Interest Reference Rates (CIRR's) são taxas utilizadas, quase que exclusivamente, em operações envolvendo ECA's. São calculadas mensalmente, baseadas na remuneração verificada nas emissões domésticas de títulos do governo do país emissor da moeda utilizada na operação de crédito. Para o dólar norte-americano, a CIRR, por exemplo, é calculada com base na taxa dos bônus do Tesouro Americano ( $T$-Bonds) e publicada pelo Export-Import Bank of the United States, em períodos mensais.

${ }^{47}$ Para projetos empreendidos fora do Brasil.
} 
qualidade e redução de desigualdades, principalmente em países em desenvolvimento. Os recursos destas agências são provenientes da contribuição de seus países membros e da emissão de instrumentos de dívida de longo prazo (FARIA, 2003).

As duas principais instituições multilaterais que atuam no financiamento do setor elétrico brasileiro são: i) o Banco Mundial, através do International Finance Corporation (IFC), braço do banco para suporte financeiro de projetos desenvolvidos pelo setor privado e ii) o Banco Interamericano de Desenvolvimento (BID).

Os organismos multilaterais, via de regra, respeitam um procedimento rigoroso para apreciação e aprovação do apoio financeiro e da liberação de recursos, tanto no que se referem aos aspectos financeiros como à abordagem ambiental, política e social do empreendimento. O rigor, que condiciona o suporte financeiro de um organismo multilateral, confere confiabilidade e elegibilidade ao empreendimento.

A participação no financiamento de projetos de infra-estrutura dos dois organismos multilaterais citados pode ocorrer, isolada ou cumulativamente, através de: i) empréstimos tipo A, com recursos próprios da instituição ou ii) empréstimos tipo B, em operações organizadas pela instituição, mas financiada com recursos provenientes de bancos comerciais.

A tônica dos empréstimos tipo B é reunir capital de terceiros para projetos de infra-estrutura atraídos pela percepção de segurança conferida ao empreendimento, vinculada à participação da agência multilateral. No empréstimo tipo $B$, os recursos são providos por bancos ou sindicatos de bancos comerciais, mas a operação é liderada, organizada e contratada em nome da agência multilateral de crédito (lender of record).

Normalmente as obrigações firmadas com instituições multilaterais são encaradas de forma prioritária pelo empreendedor. Por isso e pelo rigor da análise que envolve a contratação de financiamento de uma agência multilateral, bancos comerciais e instituições financeiras, de forma geral, atribuem um menor risco às operações que contemplem o apoio de uma instituição multilateral ${ }^{48}$.

${ }^{48}$ Quando se tem a participação de bancos comerciais em operações também apoiadas por organizações multilaterais, é comum que os bancos comerciais, como mecanismo para mitigar o risco de não pagamento, exijam cláusulas de cross default do devedor com as obrigações firmadas com a 


\subsubsection{Financiamento via Títulos de Dívida Privada}

O objetivo desta seção é discutir a captação de recursos através da emissão de títulos de dívida, pela SPE que desenvolve o empreendimento.

Não obstante a captação de recursos através de emissões de títulos de dívida seja instrumento largamente utilizado por empresas integradas do setor elétrico, com vasto portfólio de negócios, para realização de novos investimentos ou rolagem de dívidas ${ }^{49}$, observar que o foco desta seção restringe-se às emissões realizadas em nome da SPE, para captação de recursos exclusivamente destinados à operação que constitui seu único propósito ${ }^{50}$.

Em outros termos, recursos poderiam ser captados por empresas que investem no setor elétrico através de emissão de títulos de dívida e destinados a empreendimentos de geração de energia hidrelétrica como aporte de capital. A operação assim estruturada, na análise proposta nesta dissertação, cujo contorno está restrito a um único empreendimento, seria encarada como aporte de capital com contrapartida de participação acionária, de forma que a emissão que deu origem aos recursos captados, não teria qualquer vínculo com o empreendimento. $\mathrm{O}$ investidor dos títulos não enxergaria risco empreendimento, mas sim risco empresa, ou, o risco associado ao portfólio de negócios da empresa que emitiria os títulos.

Nesta seção, a pauta de discussão contempla somente a hipótese de emissão em nome da SPE, lastreada exclusivamente em seus ativos, incluídos aí, a própria usina ou a promessa de sua construção, o contrato de concessão para uso do bem público e os contratos de compra e venda de energia.

multilateral, obrigando o devedor a elevar as obrigações consigo firmadas ao mesmo status de prioridade da dívida firmada com a agência multilateral.

${ }^{49}$ No mês de outubro de 2006 , cerca de $12 \%$ do volume de títulos registrados e, aproximadamente, $35 \%$ dos processos de emissão em análise no SND - Sistema Nacional de Debêntures eram de empresas do setor de energia.

${ }^{50}$ Até outubro de 2006, estavam ativos no SND os registros das seguintes emissões de Sociedades de Propósito Específico - SPE vinculadas a empreendimentos hidrelétricos: BAESA / Usina Hidrelétrica de Barra Grande; Energética Meridional / Usina Hidrelétrica Cana Brava; Ita Energética / Usina Hidrelétrica de Itá e Machadinho Energética / Usina Hidrelétrica de Machadinho. 
A operação de captação de recursos por meio da emissão de obrigações, quando caracterizada pela transformação de um conjunto de ativos detidos por uma companhia em títulos com um determinado padrão de rendimento previamente formatado, recebe o nome de securitização (ALENCAR, 1998).

O objetivo da securitização em um empreendimento hidrelétrico pode ser aglutinar capitais para financiamento da implantação da usina ou, a depender do período em que os títulos são gerados, aglutinar recursos para fazer rolar a dívida do empreendimento, por exemplo, imediatamente após a sua implantação, com vistas a acessar um custo de capital menor, em função da não necessidade de cobertura dos riscos de construção.

Do ponto de vista do empreendedor, a operação de securitização pode ser entendida como um instrumento para antecipação de receitas, e como tal, evidentemente, tem seu custo, que é diretamente proporcional ao rendimento do título. O veículo da securitização figura assim, eficiente mecanismo para atribuir liquidez a um ativo que de outra forma estaria imobilizado, ou, ao menos, respeitaria um padrão de liquidez menor do que aquele gerado na securitização (ALENCAR, 1998).

A securitização permite alterar o padrão de liquidez do ativo sem descaracterizá-lo, do ponto de vista da segurança oferecida pelo lastro físico, ao criar condições para que as transações ocorram em valores mais singelos do que o valor integral do ativo. A possibilidade de transacionar parcelas reduzidas do ativo, através dos títulos, elimina a complexidade da operação de compra e venda, seja quanto a forma de sedimentação, seja quanto ao valor, que teria referencial não discreto, mas formado a partir de uma grande multiplicidade de transações (ROCHA LIMA JR., 1993).

No caso das hidrelétricas, a operação de securitização configura a venda do fluxo de renda do empreendimento, a ser gerado na comercialização da energia produzida. A remuneração dos títulos será formada pela soma do custo de oportunidade, parcela que reflete a contrapartida pela entrega antecipada dos recursos, mais, spread de risco, como prêmio pelo risco atribuído ao negócio. 
Em linhas gerais, a rotina para promover a securitização de um empreendimento hidrelétrico, por exemplo, pode passar pelas seguintes etapas ${ }^{51}$ :

I. o empreendedor constitui a SPE, com um capital semente, cuja contrapartida são ações ordinárias, que dão o direito de gestão sobre o ativo, porém limitado às figuras operacionais, com cláusulas pétreas no estatuto que bloqueiam decisões de mudança do propósito da sociedade e relacionadas com a alienação do ativo.

II. A SPE detém os direitos emergentes da concessão ${ }^{52}$ que, dentre outros, compreende a energia elétrica a ser produzida, a receita decorrente dos contratos de compra e venda desta energia, bem como os direitos e instalações utilizados para sua produção. O objeto de securitização contempla, portanto, o ativo imobilizado se o empreendimento estiver implantado, ou inclui apenas a promessa de implantá-lo, caso o que se tenha seja apenas um contrato de construção firmado com empresas de engenharia, construção, fornecimento e montagem eletromecânica, para entrega do empreendimento pronto e operando (conceito "turn key"). A securitização se dá por determinado valor, que reflete o preço cobrado pelo empreendedor pela parcela securitizada do ativo que, traduzido como investimento para o investidor nos títulos, representa alternativa de aplicação de recursos segura e de rentabilidade competitiva.

III. A proposta de securitização é levada à Comissão de Valores Mobiliários (CVM) para registro e emissão de títulos, em montante igual ao da parcela securitizada dos ativos de propriedade da SPE. Após o registro dos títulos na CVM, estes são subscritos e integralizados pelos investidores, a SPE constitui caixa e a obrigação de remuneração e resgate dos títulos.

A securitização pode ser feita considerando o valor total do ativo de propriedade da SPE. Neste caso, a emissão pode ser formatada a partir de duas espécies de títulos; um para integralização pelo próprio empreendedor e outro para colocação pública, de forma que o montante de recursos captados represente o total que deverá ser remunerado pela operação.

\footnotetext{
${ }^{51}$ Rotina adaptada de ROCHA LIMA JR. (1999b)

52 Como já mencionado, os contratos de concessão de uso do bem público permitem que os empreendedores ofereçam os direitos emergentes da concessão como garantia em contratos de financiamento, desde que, a eventual execução não comprometa a continuidade da exploração da usina. Sustentada em tal argumento, a rotina aqui desenhada admite a securitização dos direitos emergentes da concessão, ao entender que não existem implicações distintas, que justificassem proibição do Poder Concedente, em utilizar tal ativo como garantia de contratos de financiamento ou lastro para uma operação de securitização.
} 
Os títulos destinados à carteira do próprio empreendedor são títulos de participação, refletiriam um padrão mais alto de riscos e, naturalmente, ofereceriam maior remuneração. Os títulos destinados ao próprio empreendedor não teriam fluxo Investimento $x$ Retorno regrado, o fluxo de integralização seria aquele que completa a equação de fundos do empreendimento após ingresso de recursos provenientes de todas outras fontes e o fluxo de retorno seria formado pelo fluxo de recursos livres no empreendimento, após quitação das obrigações com terceiros, de natureza operacional, financeira e tributária.

Os títulos formatados para colocação pública, por sua vez, teriam um padrão de remuneração e devolução do principal previamente estabelecido e prioridade de retorno relativamente aos títulos destinados ao empreendedor. O volume da emissão pública seria equivalente ao valor da operação - implantação ou substituição de dívida - reduzido do valor a ser integralizado pelo empreendedor, pela via dos títulos de participação.

Alternativamente, o fluxo Investimento $x$ Retorno do empreendedor poderia ser formatado via conta de capital, em lugar dos títulos resultantes de emissão privada. Assim, a securitização contemplaria apenas debêntures para colocação no mercado, os recursos do empreendedor ingressariam no empreendimento a título de aporte de capital e o vetor de retorno seria o caixa que fica na SPE e segue para o empreendedor, pela via da distribuição de dividendos ${ }^{53}$.

Os potenciais provedores de capital privado não especialista para empreendimentos do setor elétrico, pela via das debêntures com lastro em ativos, assim como na opção pelos FIP's, são investidores institucionais, que administram grandes massas de recursos, essencialmente, aqueles cujos patrimônios obedecem a ciclos de liquidez de longo prazo, como os fundos de previdência complementar.

O perfil conservador e o longo prazo de maturação do investimento tornam o setor de energia destino alternativo de recursos na economia, para investidores com relativa aversão ao risco, cujos objetivos de poupança apontam, com mais força, para a preservação de valor em detrimento da alta rentabilidade. A abordagem do risco do investimento em geração

\footnotetext{
${ }^{53}$ A opção pelos títulos de participação em detrimento da conta de capital pode trazer vantagens de natureza tributária ao empreendedor, na medida em que o caixa gerado na SPE, que compõe o fluxo de retorno do empreendedor, deixa a SPE sob a rubrica de despesa financeira, item dedutível da base de cálculo do imposto sobre a renda, devido pela SPE.
} 
hidrelétrica será objeto da próxima seção e da análise da qualidade do investimento desenvolvida no capítulo 5 .

No capítulo 5, da análise da qualidade do investimento em geração, a equação de fundos do empreendimento protótipo será composta de recursos do empreendedor, aportados via conta de capital $^{54}$, recursos do BNDES e recursos captados em mercado de capitais, via emissão pública de debêntures.

${ }^{54}$ Admitidos como provindos tanto de empresas do setor como de investidores institucionais. Destes, por meio dos FIP's. 


\subsection{RISCOS DA ATIVIDADE DE GERAÇÃO DE ENERGIA HIDRELÉTRICA}

\subsubsection{Riscos de Mercado}

Os riscos de mercado estão vinculados às condições de competitividade do agente produtor, essencialmente, no que se refere ao preço da energia submetido nas ocasiões dos leilões de comercialização no ambiente regulado ou nas negociações bilaterais no ambiente livre.

A competitividade do empreendedor estará relacionada diretamente com seu posicionamento, relativamente à oferta concorrente, no que se refere aos custos previstos para implantação da usina, aos custos previstos para operação e manutenção e à configuração da sua equação de funding. A condição de competitividade do empreendedor é função direta da combinação do seu posicionamento perante a concorrência nestes três aspectos, cuja definição direcionará a determinação do preço de energia necessário para remunerar o empreendedor segundo seus parâmetros de atratividade.

No ACR, o preço da energia, conforme descrito na seção anterior é, após a confirmação da habilitação técnica do agente vendedor pela ANEEL, o único fator de diferenciação entre os geradores, cuja definição acarretará na contratação ou não da energia ofertada. No ACL, o preço é certamente a variável preponderante para escolha do fornecedor de energia, mas pela maior flexibilidade dos contratos aí firmados, outras variáveis podem contribuir para estabelecimento da competitividade do gerador.

No setor elétrico, o risco de inserção de mercado é limitado, uma vez que a decisão de investimento está, na maior parte dos casos, vinculada ao vislumbre de contratos firmes de compra e venda de longo prazo. Os empreendedores vencedores, que adquirem o direito de uso do bem público nas licitações de novas concessões da ANEEL, devem definir, perante este órgão, a quantidade de energia que ofertarão no ACR e no ACL. No ACR, os contratos para contratação de energia hidrelétrica nova deverão ter prazo de 30 anos e preço fixo, já no ACL, os contratos serão firmados em condições livremente negociadas podendo prever preços fixos ou variáveis e prazos também flexíveis. 
A definição da quantidade de energia derivada para contratação no ACR e no ACL será função da forma como o empreendedor enxerga o comportamento futuro dos preços de energia, bem como de seus objetivos de rentabilidade e de seu grau de aversão a riscos. A possibilidade de firmar contratos com prazos menores no ACL permite ao empreendedor expor-se às oscilações dos preços de energia no ambiente livre de mercado, com o ônus e os ganhos que implicam tal exposição. A volatilidade dos preços de energia está associada diretamente à hidrologia, ao grau de armazenamento dos reservatórios e às condições de afluência dos rios e, em um horizonte de médio a longo prazo, à elasticidade oferta-demanda.

A observação do comportamento dos empreendedores do setor mostra que os empreendimentos só são levados a cabo, após a pré-contratação firme, no longo prazo, de parcela significativa da energia assegurada do empreendimento que, assegure níveis mínimos de remuneração do empreendedor.

Por outro lado, seja em função das condições da demanda quando da tomada da decisão de investimento, ou ainda, por eventual quebra de contratos de longo prazo ou necessidade de migração entre os ambientes livre e regulado, o empreendedor pode ficar exposto às condições de preço de energia no ACR e ACL ao longo do ciclo de operação do empreendimento.

Destaca-se que, não há, no ACL, exigência de contratação antecipada da energia, como ocorre no ACR. Desta forma, o agente gerador que decide destinar parte de sua energia à comercialização no ACL, não raro, iniciará a construção da usina com parte da energia assegurada não contratada ${ }^{55}$.

Ainda que não seja um vetor de risco para o investidor cuja energia assegurada está toda contratada nos leilões de energia proveniente de novos empreendimentos, outro fator

55 A não imposição da contratação antecipada aos consumidores livres, implica em risco de atendimento do mercado no longo prazo. No ACR, os distribuidores contratam a maior parcela de sua demanda nos leilões que ocorrem de 3 a 5 anos antes do início de suprimento, fazendo com que os sinais para o investimento na expansão da geração sejam disparados pelos próprios agentes consumidores, em prazo suficiente para implantação dos novos empreendimentos. Ocorre que a contratação com antecedência de 3 a 5 anos da energia, age como incentivo ao investimento em geração, uma vez que o investidor, ao ter assegurado o contrato de compra e venda de energia de longo prazo, vê reduzir o risco do investimento.

No ACL, como os consumidores livres podem contratar energia às vésperas da realização da demanda, não há sinalização do mercado para novos investimentos em geração, daí o risco associado à expansão da capacidade instalada. 
associado ao Risco de Mercado, para investidores com exposição em empreendimentos existentes, é a possibilidade de devolução, pelos distribuidores, de parte da energia contratada. Os CCEAR`s, para energia proveniente de empreendimentos existentes, prevêem a devolução de até $4 \%$ do montante de energia contratada por ano, por parte do distribuidor, como mecanismo de compensação para a situação de adesão de consumidores, antes regulados, ao status de consumidor livre.

Observa-se que, do ponto de vista do agente gerador, a redução da quantidade contratada com determinado distribuidor, em função da adesão de consumidores ao status de consumidor livre, representa perda de carteira ou fatia de mercado. De outro lado, do ponto de vista do conjunto de agentes do sistema gerador, não há redução de mercado, uma vez que o abandono da condição de regulado representa aumento correspondente do mercado livre, sem redução do mercado global. Tal fato só representaria perda efetiva do mercado, para todo o sistema gerador, se o consumidor deixa a posição de consumidor regulado ou livre para tornar-se auto-produtor de energia, ou, se outros produtores independentes entram no mercado, no momento da devolução, para atendimento dos consumidores dissidentes.

\subsubsection{Projetos Estruturantes: Riscos de Perturbação do Equilíbrio de Mercado}

No primeiro semestre de 2006, o MME publicou o Plano Decenal de Energia Elétrica (PDE) para o período 2006-2015. O PDE, elaborado pela EPE, estabelece o crescimento da capacidade instalada dos 93,7GW, em jan/06, para 134,7GW, em 2015, o que corresponde a um crescimento médio de $4,4 \%$ ou de $4,1 \mathrm{GW}$ ao ano. O plano estima que serão necessários aproximadamente $\mathrm{R} \$ 74$ bilhões até 2015 para atender aos objetivos de expansão traçados, sendo 59 bilhões destinados às hidrelétricas e $\mathrm{R} \$ 15$ bilhões às termelétricas.

Aproximadamente um terço da expansão projetada para o decênio 2006-2015, segundo o plano, está sustentado na implantação de três projetos, chamados estruturantes: (i) Angra III, com 1.309 MW; (ii) o complexo do Rio Madeira na Região Norte, formado pelos aproveitamentos hidrelétricos de Jirau, com 3.300 MW de capacidade e Santo Antônio, com 3.150 MW de capacidade e (iii) aproveitamento hidrelétrico de Belo Monte, também situado na Região Norte, com 5.500 MW. 
Os três projetos de natureza hídrica citados, em vista das suas dimensões, requisitam volumes elevados de investimentos para sua implantação, bem como volumes elevados para ampliação da rede de transmissão necessária para conectar as usinas ao $\mathrm{SIN}^{56}$ e permitir o transporte da energia aos subsistemas mais distantes, com maior necessidade de carga. Em vista dos montantes elevados envolvidos, os projetos hidrelétricos estruturantes devem ser tratados, pelos agentes e órgãos do setor, de maneira particular.

A realização destes empreendimentos pressupõe a comunhão dos setores públicos e privados, em função da demanda elevada por investimento e da conseqüente exposição excessiva ao risco que, dadas as extensões, não poderiam ser suportados por apenas uma das esferas, público ou privada, isoladamente. A sinalização do mercado, no concernente à formatação destes empreendimentos, parece apontar para uma estrutura onde os recursos sejam captados, de forma prevalente, por agentes privados em parceria, mas com parte dos riscos assumidos pelo Estado.

A estruturação destes empreendimentos, pelo tom peculiar, é tema que foge ao escopo deste trabalho. O trabalho mantém foco nos empreendimentos de geração de energia hidrelétrica, cujas dimensões, por si só, não seriam suficientes para provocar oscilações de comportamento do mercado ou movimentos nos fluxos de investimentos para o setor. Não obstante, a discussão do tema "projetos estruturantes" faz-se pertinente em função dos efeitos que a implantação destes empreendimentos pode trazer aos outros empreendimentos do setor.

O processo de licitação dos aproveitamentos Jirau, Santo Antonio e Belo Monte exige critérios especiais, uma vez que a provável prerrogativa da participação pública, seja na provisão de recursos, seja na assunção de riscos, não implicará em concessão de direito de

\footnotetext{
${ }^{56}$ A questão dos custos com transmissão para conectar os projetos hidrelétricos estruturantes ao SIN é ponto central do debate entre agentes do setor, sobre a viabilidade da implantação destes empreendimentos. Atualmente os geradores e distribuidores pagam a Tarifa de Uso do Sistema de Transmissão (TUST), de forma proporcional à quantidade de energia que, respectivamente, injetam e retiram do sistema. Os recursos reunidos por conta do pagamento da TUST compõem, assim, a receita das concessionárias de transmissão.

A licitação de novas concessões de transmissão, para conexão dos projetos estruturantes ao SIN, exigiria aumentos na TUST necessários para devolver e remunerar os investimentos imobilizados nas novas linhas do sistema.

Esses aumentos seriam pagos, ou exclusivamente pelos empreendedores dos projetos estruturantes, o que faria inviabilizar estes novos empreendimentos, ou seriam divididos entre agentes do setor, o que oneraria empreendimentos já instalados e em fase de implantação com energia já contratada, cuja decisão de investimento foi tomada sem a consideração da hipótese de aumento futuro excepcional da TUST.
} 
exploração a outrem, mas sim de seleção de sócio privado para desenvolvimento do empreendimento.

Adicionalmente, a comercialização da energia proveniente de projetos estruturantes será provavelmente tratada, também, de forma específica, quiçá em leilões exclusivos, dados os efeitos potencialmente negativos sobre os demais investimentos em geração que se poderá produzir, caso a energia destes empreendimentos seja comercializada nos leilões de energia nova, nos moldes dos ocorridos até então, em processo de concorrência direta com demais empreendedores.

A formatação de leilões específicos para comercialização da energia a ser produzida nestes empreendimentos parece ser essencial para evitar impacto nos movimentos de preço de energia para contratação no longo prazo. Nos moldes dos leilões de energia nova ocorridos até então, a participação de empreendimentos com capacidade instalada similar à dos projetos ditos estruturantes provavelmente teria sido indutora dos preços de energia e, possivelmente, se contratada, teria esgotado a quantidade demandada pelos distribuidores.

Ademais, caso o preço de energia, necessário para remunerar os investimentos mobilizados para implantação dos empreendimentos estruturantes, resulte excessivo em relação ao praticado nos últimos eventos de comercialização, há que se considerar a hipótese de que seja decretada a compra compulsória da energia produzida por estes empreendimentos, caso sua implantação revele-se imprescindível para garantia de suprimento do mercado. Ou, que sejam criados encargos, entre agentes do setor e consumidores, para subsidiar a implantação destes aproveitamentos.

Em outra análise, a decisão de implantação destes empreendimentos, ao menos no curto prazo, altera a prioridade para concessão de novos aproveitamentos, postergando concessões de aproveitamentos menores que se fariam necessárias, caso os projetos estruturantes fossem preteridos.

Mesmo considerando a criação de ambiente exclusivo para comercialização da energia produzida por projetos ditos estruturantes, a realização destes empreendimentos pode trazer impactos também ao CMO e, consequentemente, ao PLD, verificado no mercado de curto prazo, com possíveis impactos a geradores já instalados, cuja estratégia de comercialização 
contemple exposição nestes mercados. O impacto sobre os preços de energia no curto prazo pode ocorrer também caso os empreendimentos estruturantes não sejam viabilizados ou implantados nos prazos previstos, uma vez que todo o planejamento da expansão está atualmente sustentado na hipótese de implantação destes empreendimentos. A não realização destes empreendimentos pode fazer aumentar o risco de déficit de energia no sistema e, por consequiência, o CMO e o preço da energia no mercado de curto prazo.

Enfim, seja pelos motivos aqui aventados ou por outros ainda difusos, os projetos estruturantes têm que ser vistos como especiais e tratados, pelos agentes de mercado, como vetor de risco, pela potencial capacidade de afetar o equilíbrio de mercado e, por consequiência, a percepção sobre os riscos de novos investimentos.

\subsubsection{Risco de Não Geração da Energia Contratada}

O segundo veio de risco está associado à condição de não geração da totalidade da energia contratada. Este risco está presente, essencialmente, nos empreendimentos de geração de fonte hídrica, onde o volume de geração fica vulnerável às condições hidrológicas da região onde está localizada a usina. No ACR, para os projetos hidrelétricos, a modalidade dos contratos de compra e venda, conforme imposição do regulador, deve ser, obrigatoriamente, Quantidade de Energia. Nesta modalidade contratual, o risco de geração é assumido pelo agente gerador, que deve garantir o suprimento da quantidade de energia pactuada no conjunto de contratos bilaterais firmados.

Os riscos de geração hídrica no novo modelo são em parte mitigados pelo MRE, que procura garantir o cumprimento das obrigações dos geradores estabelecidas em contratos bilaterais, distribuindo, para efeito de contabilização, a energia gerada pelo conjunto de hídricas do sistema, de forma proporcional à participação de cada usina na energia assegurada do sistema. A transferência de energia entre usinas é feita ao preço mínimo da energia, definido como o valor suficiente para cobertura dos custos de operação e manutenção e do pagamento da tarifa de compensação financeira pelo uso do recurso hídrico. 
Caso a quantidade de energia contratada não seja atingida após a aplicação do mecanismo de realocação, aí sim, os geradores ficam sujeitos à exposição de preços no mercado de curto prazo, ao PLD.

O gerador fica, portanto, exposto ao mercado de curto prazo, sempre que todo o sistema hídrico gera energia em quantidade inferior à energia assegurada. A situação de geração inferior à assegurada ocorre em cenários de hidrologia crítica, de geração extraordinária de usinas que não participam do MRE, como também por redução generalizada do consumo. Considera-se, por exemplo, a hipótese em que o consumo ocorre em patamar bastante inferior ao esperado pelo concessionário de distribuição.

Nesta situação, uma pequena parcela de usinas é despachada e todo o sistema hídrico, por consequiência, produz quantidade de energia inferior à energia assegurada. O gerador hídrico recebe do distribuidor o pagamento correspondente à quantidade de energia de placa dos CCEAR's e registra posição devedora no mercado de curto prazo. O gerador liquida a posição devedora, no mercado de curto prazo, ao PLD, para a diferença entre a energia a ele atribuída no MRE e a energia de placa dos CCEAR's, pela qual recebeu do distribuidor.

Quando esta situação ocorre, o gerador hídrico liquidará posição devedora no mercado de curto prazo, junto a um outro agente com posição credora, nesta situação, muito provavelmente um distribuidor, que pagou pelo valor de face da energia nos CCEAR's, mesmo sem consumi-la.

A diferença, do ponto de vista dos riscos de exposição no mercado de curto prazo, entre esta situação e a situação de não geração por condições hidrológicas críticas é que, na primeira, a tendência natural é PLD baixo, como função do excesso de oferta de energia. De forma contrária, na ocasião de condições hidrológicas críticas, a tendência é de PLD alto, função da insuficiência da oferta hídrica e da provável necessidade de acionamento das térmicas.

Apesar de o MRE objetivar o compartilhamento do risco hidrológico, a alocação deste risco ao agente de geração, nos contratos de quantidade de energia, é ponto delicado da política setorial, na medida em que o risco hidrológico não é passível de gestão pelo gerador. Em realidade, o único agente do setor, com algum poder de gestão sobre o risco hidrológico, é o ONS, enquanto coordenador do despacho centralizado. 
No modelo de despacho centralizado, o ONS tem, ao seu cargo, a ampla responsabilidade de definir o ordenamento de despacho, segundo critério de menor custo, com atenção à segurança do abastecimento no curto e médio prazos.

Ocorre que a alternativa de menor custo conflita com a alternativa de maior segurança. Para exemplificar, supõe-se a simulação da decisão de despacho, no sistema hidrotérmico brasileiro, em momento posterior a um período de chuvas intensas em que se tenha elevado o nível nos reservatórios das usinas do sistema hídrico. Neste cenário, a alternativa mais econômica seria despachar o maior número de usinas hidrelétricas, em detrimento das térmicas, até esgotamento dos reservatórios do sistema, visando manter o preço da energia em seu limite inferior até quando possível. A alternativa mais segura, entretanto, seria balancear o despacho hídrico e térmico, de forma a utilizar o volume energético armazenado nos reservatórios hídricos de maneira racional, mantendo níveis mínimos nos reservatórios, como reserva para eventualidade de períodos de hidrologia crítica no futuro.

Na hipótese acima, a adoção do critério de maior economia, sem preocupação com a segurança do sistema, poderia levar o sistema a uma situação de racionamento de energia, em caso de períodos de secas futuros, em que se faria necessário o despacho de usinas térmicas para atendimento da demanda. Como as usinas térmicas não participam do MRE e a energia térmica é, em média, sensivelmente mais cara que a energia hídrica, o preço da energia no mercado subiria consistentemente, deixando os geradores, contratados na modalidade quantidade de energia, totalmente descobertos, em posições deficitárias no mercado de curto prazo, às quais teriam de ser liquidadas a um PLD elevado. Em outros termos, os geradores hídricos poderiam ser duramente penalizados, pela má gestão do nível dos reservatórios.

Ainda que reconheça-se o rigor técnico-operacional do ONS na coordenação do despacho, assim como a atenção à segurança do suprimento no desenho institucional do novo modelo, o gerador hidrelétrico, contratado na modalidade quantidade de energia, fica exposto à ação do operador do sistema no que cabe à gestão dos reservatórios hídricos. O vetor de risco hidrológico é gerenciado pelo operador do sistema, mas pode onerar diretamente o agente de geração, cuja maior ou menor exposição está vinculada à qualidade da gestão dos reservatórios. 
Outro risco a que fica exposto o agente gerador é o risco de redução de sua energia assegurada nos eventos de revisão. Segundo o decreto 2.655 de 02 de julho de 1998, o valor da energia assegurada alocado à cada usina do sistema será revisto a cada cinco anos, ou na ocorrência de fato relevante. As revisões não poderão implicar em redução superior a $5 \%$ do valor estabelecido na última revisão e, no todo, ao longo do período de concessão, a $10 \%$ do valor de base, constante do contrato de concessão. O valor revisto da energia assegurada passa a ser o novo lastro de energia da respectiva usina, para contratações no ACR e ACL e para participação no MRE.

Portanto, eventuais reduções na energia assegurada implicariam em menor quantidade de energia, diminuindo espaço para estabelecimento de novos contratos de compra e venda, e aumentariam a exposição do agente gerador no mercado, ao provocar redução na quantidade de energia atribuída ao gerador no âmbito do MRE e ao exigir que o gerador adquirisse energia de outros agentes de mercado para atender seus contratos, na hipótese em que a energia assegurada anterior à revisão estivesse, por exemplo, toda contratada em contratos de longo prazo no ACR e ACL.

\subsubsection{Riscos de Inadimplência do Agente Comprador}

O terceiro risco associado à comercialização de energia elétrica é o risco comum a qualquer transação comercial, de inadimplência do agente comprador. Nos contratos firmados no ACL, o risco de inadimplência deve ser analisado a partir da capacidade de pagamento de cada agente comprador isoladamente. No ACR, como os contratos são firmados com todos os distribuidores segundo proporção direta da participação de cada um na quantidade total demandada no ACR, o risco de não recebimento fica distribuído pelo número elevado de contratos firmados. Adicionalmente, no ambiente regulado, a obrigatoriedade do estabelecimento de contratos de constituição de garantias e, também, a exigência de plena quitação das obrigações intra-setoriais como requisito para a aplicação dos repasses tarifários aos consumidores finais, por parte dos distribuidores, contribuem para afastar o risco de inadimplência. 


\subsubsection{Riscos Regulatórios e Políticos}

O fato de ser um setor de negócios de longo prazo, baseado no direito de exploração de bem público, resguardado por contrato de concessão travado entre a União e o privado, portanto de natureza administrativa, combinado ao amplo escopo estatal no planejamento e operação da política setorial, enredam ao setor riscos de origem extraordinária usualmente atribuídos ao Poder Concedente: o risco regulatório e o risco político.

Com base na classificação adotada por SCHUMAHER (2003), o risco político abrange ações das autoridades em geral que não têm relação direta com o contrato, mas neles se refletem, na medida em que modificam obrigações legais após a assinatura do contrato e, com isso, repercutem na estrutura de custos do concessionário. Como exemplo, as modificações na legislação tributária, na estrutura de encargos setoriais e na legislação ambiental relacionada.

O risco regulatório, por seu turno, segundo DI PIETRO (1996) apud SCHUMAHER (2003), relaciona-se diretamente com o contrato e compreende qualquer conduta do Poder Concedente que, como parte contratual, torne impossível a execução do contrato ou provoque seu desequilíbrio econômico-financeiro. Como exemplo, mudanças na regra de comercialização da energia, criação de subsídios ou isenções para determinada categoria de usuários, promoção de programas de redução de consumo da energia e rescisão do contrato ou encampação da concessão.

Some-se a estes vetores, aquele associado à assimetria de informação em favor do Estado que, no setor elétrico, atua como empresário, concessionário ou agente produtor na qualidade de controlador de empresas públicas de geração, além de Poder Concedente nos contratos de concessão e agente regulador, organizador e condutor dos leilões de comercialização de energia. A atuação híbrida do Estado desperta para o tema da concorrência não isonômica entre a atividade empresarial das esferas pública e privada, em setor controlado unilateralmente pela primeira.

Ainda que o modelo regulatório vigente tenha imprimido maior segurança ao processo de contratação de energia, com a obrigatoriedade da contratação de longo prazo, criando condições, neste tema, propícias para a mobilização de recursos para o setor, a ampla atuação 
estatal, a recentidade da regulação e as constantes alterações regulatórias introduzidas no setor ao longo da década de 90 e da atual, bem como a relativa submissão do modelo e operação setorial à vontade da Administração em exercício, tornam os riscos de natureza regulatória e política imanentes à atividade empresarial no setor elétrico.

\subsubsection{Riscos Ambientais}

Outro tópico que contribui para frear uma maior participação do investidor privado é a questão ambiental. As usinas hidrelétricas devem, obrigatoriamente, passar por um processo de aprovação ambiental que contempla, a licença prévia, a licença de instalação e a licença de operação, respectivamente, a serem emitidas antes do processo de licitação para concessão, antes do início das obras de construção e antes do início do enchimento do lago. Atualmente, a obtenção da licença prévia para usinas levadas ao leilão é atribuição da EPE, que prioriza e seleciona as concessões de novos aproveitamentos. Apesar da obrigatoriedade da emissão da licença prévia ambiental em data anterior à do leilão de concessão de novos aproveitamentos, o risco ambiental para o investidor privado persiste durante todo o horizonte do contrato de concessão, uma vez que a licença prévia não garante a licença de instalação, que não assegura a obtenção do licenciamento para a operação, que, por sua vez, está sujeita à renovação durante o ciclo operacional em períodos quadrienais. As licenças ambientais são outorgadas, com base em parecer do Instituto Brasileiro do Meio Ambiente e dos Recursos Naturais Renováveis (IBAMA), pelo Ministério Público, de forma autônoma, pelo procurador responsável pelo processo.

Atrasos na emissão das licenças de instalação e de operação podem, por exemplo, provocar alterações no cronograma de implantação e entrada em operação comercial da usina, que dificultem ou até impossibilitem o cumprimento de prazos estabelecidos nos contratos de compra e venda firmados antecipadamente. Os atrasos na obtenção das licenças podem estar associados a aumento do volume de investimentos, necessários para abreviar o cronograma de implantação, ou adquirir energia de outros agentes para fazer frente aos contratos de compra e venda de energia, considerando a impossibilidade de entrada plena em operação, em data anterior ao início da vigência dos contratos de compra e venda de energia estabelecidos. 


\subsubsection{Riscos Associados à Macroeconomia}

Os riscos relativos à macroeconomia nacional fazem referência ao descolamento de comportamento, entre o cenário planejado, utilizado como base para a tomada de decisão, e a realidade, dos indicadores macroeconômicos que afetam diretamente as variáveis do empreendimento, como parâmetros de evolução de inflação, taxa de cambio e taxa de juros. O comportamento destas variáveis, a depender do grau de divergência em relação ao cenário que balizou a decisão do empreendedor, pode trazer impactos significativos à qualidade econômica do empreendimento.

A evolução não aderente ao cenário de planejamento da inflação pode, por exemplo, implicar em aumento dos custos de implantação, bem como aumento relativo dos custos de operação e manutenção frente à receita, durante o ciclo operacional, caso as receitas e custos operacionais respeitem índices de reajustes distintos. Além disso, como o encaixe de receitas ocorre em bases mensais e o reajuste para recomposição do poder de compra da tarifa ocorre, pontualmente, em períodos anuais, existe perda de valor real das receitas do gerador ao longo de um ano. Estas perdas podem gerar impactos na rentabilidade do empreendedor, a depender também da intensidade e do comportamento mensal do fluxo de evolução da inflação.

A evolução da taxa de cambio pode também trazer impactos à rentabilidade do empreendedor, a depender do peso dos itens a serem adquiridos em moeda estrangeira no orçamento de implantação e das contas de operação e manutenção, bem como na cesta de custos financeiros, caso parte da dívida contraída pela SPE esteja indexada à moeda estrangeira. Em geral, riscos de exposição à variação cambial são mais significativos durante os anos de implantação do projeto, uma vez que parte dos bens de capital, essencialmente equipamentos eletromecânicos incorporados ao empreendimento, podem ser adquiridos no exterior.

Por fim, os juros do financiamento podem ser contratados em bases fixa, variável, ou fixa mais variável. Quando os juros têm componente variável e seguem a evolução de determinada taxa de juros de uso corrente na economia, há o risco de descolamento do índice em relação ao cenário que sustentou a decisão de investir. O serviço da dívida contratada pela SPE pode, por exemplo, estar preso, entre outros, ao comportamento do Certificado de 
Depósito Interbancário (CDI), Taxa de Juros de Longo Prazo (TJLP), London Interbank Offered Rate (LIBOR). A dívida pode também prever atualização do valor nominal por determinado índice de inflação ou variação cambial.

\subsubsection{Riscos de Financiabilidade}

No setor elétrico brasileiro, é comum que a tomada de decisão do empreendedor e a participação no leilão de comercialização de energia no ACR ocorra antes da confirmação da data de ingresso e das condições de participação de financiadores e outros investidores no projeto. Desta forma, pela morosidade dos processos de enquadramento e efetivação da contratação das linhas de financiamento ou de emissões privadas, que necessitam também período razoável para sua estruturação e, em muitos casos, condições de mercado específicas para colocação, o empreendedor pode não efetivar a equação de fundos do empreendimento segundo a composição e as condições que fundamentaram a tomada de decisão. Os custos e as condições de ingresso, retorno e remuneração dos recursos de terceiros no projeto afetam, de forma sensível, a quantidade e o grau de remuneração do capital próprio do empreendedor imobilizado no empreendimento.

Atrasos no ingresso de recursos de terceiros de longo prazo no empreendimento podem, por exemplo, obrigar o empreendedor a estender o montante de capital próprio que estimou aportar no empreendimento ou a recorrer a empréstimo de curto prazo do tipo ponte, onerando

o custo de captação e, em ambos os casos, reduzindo sua expectativa de retorno no empreendimento.

\subsubsection{Riscos de Construção}

No momento da tomada de decisão de empreender no segmento de geração hidrelétrica, normalmente, se tem parâmetros firmes de custo e condições de construção. Em muitos casos, o empreendedor possui contrato com empresa prestadora de serviços de engenharia, 
construção e fornecimento de equipamentos, onde estão pactuados preço e prazo para entrega do empreendimento pronto para operar.

Contudo, ainda que o empreendedor busque proteger-se contra riscos de distensão dos custos e prazos de construção, através da firma de contratos de preço global ou turn key - onde o ônus de variações de quantidades de serviço, custos e prazos de construção é atribuído ao provedor de serviços de construção e fornecimento de equipamentos -, quaisquer eventos e variações de componentes de custos estranhos à atividade do prestador de serviço de construção e fornecimento oneram diretamente o empreendedor. Adicionalmente, ao firmar o contrato na modalidade turn key, o empreendedor não elimina o risco de construção, mas tão somente o substitui pelo risco de performance das empresas contratadas para execução das obras civis e eletromecânicas.

$\mathrm{Na}$ implantação de uma usina hidrelétrica, dada as dimensões da intervenção e à forte interação do projeto com o ambiente em que se situa, fatores de natureza geológica e hidrológica são potenciais vetores de risco para o período de implantação da usina hidrelétrica. A existência de solos com composição distinta daquele identificado nas sondagens, que fundamentaram o projeto básico da planta de geração, pode implicar em aumento sensível do custo de construção e atraso na entrada em operação da usina. Além disso, a ocorrência de períodos onde a vazão do rio supera a vazão de dimensionamento das estruturas provisórias de construção, ou períodos de chuva intensa e enchentes que perturbem o bom andamento das obras de implantação, podem, também, trazer implicações ao cumprimento das metas de custos e prazos de implantação do empreendimento.

Em síntese, compõem a gama de riscos de construção, os riscos de quebra de eficiência de mão de obra e equipamentos alocados no empreendimento, riscos associados a erros de projeto e execução, falhas oriundas do processo de fabricação, transporte, armazenamento, montagem e instalação de equipamentos eletromecânicos, riscos de perdas e danos em decorrência de acidentes, riscos associados a atos da natureza e a questões ambientais, sociais e de força maior.

\subsubsection{Riscos de Operação e Manutenção}


Outro vetor de risco, que também será analisado, está associado às flutuações de custos de operação e manutenção da usina. A operação do empreendimento pode constituir serviço sob atribuição do empreendedor, caso seja esta sua atividade fim, ou sob atribuição de um terceiro, contratado exclusivamente para tal. As variações de custos operacionais, de forma geral, têm sua origem nas distensões efetivas de custos em relação aos parâmetros que compõem o cenário referencial, no qual baseou-se a decisão de investimento, ou, nas variações de comportamento dos índices de reajuste de custos, que provoquem desvios do valor de descolamento entre indexadores de inflação de receitas e de custos, em relação às expectativas de planejamento.

As variações de custos de operação e manutenção podem estar associadas à quebra de eficiência operacional, em virtude de baixo desempenho de mão de obra e equipamentos ao longo do ciclo operacional, limitações para operação por força de atos da natureza, acidentes, questões ambientais e sociais e eventos de força maior. 


\section{EMPREENDIMENTOS DE GERAÇÃO DE ENERGIA HIDRELÉTRICA: ANÁLISE DA QUALIDADE DO INVESTIMENTO}

\subsection{ANÁLISE DA QUALIDADE DO INVESTIMENTO - ABORDAGEM METODOLÓGICA ${ }^{57}$}

O objetivo deste capítulo é gerar um conjunto de indicadores que permitam, àquele que empreende, reconhecer a qualidade do investimento no empreendimento de geração de energia hidrelétrica. Do ponto de vista do investidor, o conjunto de indicadores gerados em uma análise da qualidade do investimento compõe a base de informação que sustenta a decisão de empreender.

Os indicadores devem oferecer ao empreendedor parâmetros indicativos do binômio Rentabilidade x Risco do investimento. Os indicadores da qualidade do investimento devem permitir ao empreendedor enxergar o desempenho do empreendimento segundo três aspectos: i) capacidade de sustentação de sua equação de fundos; ii) velocidade e grau de remuneração oferecido aos recursos imobilizados na sua implantação e iii) segurança, ou medida da capacidade do empreendimento de manter seu desempenho econômico-financeiro preso às expectativas de comportamento que sustentaram a decisão de investir.

Os indicadores da qualidade são gerados a partir da simulação do conjunto de transações financeiras que caracterizam os ciclos de implantação e operacional do empreendimento, conforme rotina abaixo sintetizada:

1. Construção de um Modelo Matemático, que simula as transações financeiras verificadas no ambiente do empreendimento, dentro de um determinado horizonte de análise.

2. Introdução, no modelo, do Cenário Referencial. No cenário referencial, são parametrizadas variáveis de comportamento do empreendimento e de seu ambiente.

\footnotetext{
${ }^{57}$ A rotina e os conceitos de Análise de Investimento utilizados nesta seção estão descritos de forma sucinta, porque estão baseados em doutrina já amplamente disseminada no Grupo de Real Estate da Escola Politécnica da USP.

Para aprofundamento no tema, consultar www.realestate.br.
} 
O cenário referencial deve conter a melhor expectativa do planejador, do ponto de vista da qualidade e sustentação da informação. As variáveis são definidas, no cenário referencial, como valores discretos.

3. Extração dos Indicadores da Qualidade do investimento, no cenário referencial. Os indicadores serão calculados com base no fluxo de Investimento $x$ Retorno do empreendedor e deverão mostrar a exposição do empreendedor no empreendimento, o grau e a velocidade de remuneração dos recursos imobilizados em sua implantação.

4. Análise de Risco. A análise de riscos consiste na identificação do nível de desvio dos indicadores da qualidade, para a hipótese de que o comportamento das variáveis, do sistema empreendimento como do seu ambiente, fujam das expectativas lançadas no cenário referencial, porque ocorrem distúrbios de comportamento, ou conturbações no ambiente (ROCHA LIMA JR., 1998).

Para análise da qualidade, decidiu-se utilizar como base um empreendimento protótipo. Como a proposta consiste em qualificar o investimento no setor e não em um empreendimento em específico, optou-se pela construção de um protótipo, cuja formatação deve conter parâmetros representativos do espectro de empreendimentos hidrelétricos concedidos no Brasil, nos leilões de energia realizados em dez/05 e out/2006.

Em outros termos, o investidor, ao acessar os indicadores da qualidade a serem produzidos a partir do estudo da qualidade do investimento baseado no protótipo, deve ter uma imagem do binômio Rentabilidade $x$ Risco do investimento no segmento dos empreendimentos hidrelétricos.

A decisão pelo empreendimento protótipo, em detrimento de um estudo de caso, que teria como base um empreendimento real isolado, justifica-se pela possibilidade de extrair da análise vieses que pudessem remontar para características peculiares de um único elemento, quando a proposta é retratar características de uma amostra representativa dos empreendimentos deste segmento. Os estudos baseados em um único caso seriam preferidos em relação aos protótipos, se o objetivo da análise estivesse em algo peculiar, cuja existência fosse apenas verificada em alguns poucos elementos de uma amostra de empreendimentos. 
Ademais, a opção pelo protótipo pressupõe maior liberdade ao planejador na simulação, quando a intenção é alternar ou comparar caminhos de decisão, que em um estudo de caso já estariam trilhados.

O empreendimento protótipo nesta dissertação retrata as características dos empreendimentos hidrelétricos concedidos pelo MME nos leilões realizados após a publicação da lei 10.848 e do decreto 5.163. Os parâmetros extraídos da amostra de empreendimentos concedidos nos últimos leilões foram a base para arbitragem dos valores de energia assegurada, custos de implantação, preço e quantidade de energia destinada à comercialização no ACR.

O ANEXO A traz as principais características dos empreendimentos hidrelétricos concedidos nos leilões de dez/2005 e out/2006. 


\subsection{O CENÁRIO REFERENCIAL DA ANÁLISE}

\section{Características Gerais do Empreendimento Protótipo}

O desenho do empreendimento protótipo, com a arbitragem dos parâmetros que compõem o cenário referencial, seguirá a ordenação temporal, composta pelo ciclo de formatação, ciclo de implantação e ciclo operacional.

O horizonte de análise será de 35 anos, prazo do contrato de concessão firmado entre o empreendedor e MME. Não obstante o ciclo de formatação iniciar-se alguns anos antes do evento de licitação da concessão, com os estudos de inventário e viabilidade, o horizonte de análise tem início a partir da assinatura do contrato de concessão, uma vez que, apenas a partir desta data, a concessão do direito de exploração é confirmada.

Do período compreendido entre a assinatura do contrato de concessão e a plena operação do empreendimento, cerca de um ano é destinado ao desenvolvimento do projeto básico do empreendimento, detalhamento dos projetos de controle ambiental e implantação das primeiras recomendações dispostas no EIA/RIMA, com vistas à obtenção da licença de instalação, que autoriza o início das obras de implantação. Admitiu-se que a licença de instalação só será obtida após um ano da assinatura do contrato de concessão. Desta forma, as obras são efetivamente iniciadas no segundo ano do horizonte de análise.

Admitiu-se cronograma total de implantação com duração de 60 meses, 12 meses para desenvolvimento do projeto básico da usina e obtenção da licença de instalação e 48 meses, de obra civis e instalação de equipamentos eletromecânicos. Aos 50 meses do início do contrato de concessão, a primeira de seis unidades de geração entra em operação comercial. Daí em diante, a cada 2 meses, uma nova unidade de geração inicia a operação. Desta forma, transcorridos 60 meses do início do contrato de concessão todas as seis unidades de geração estarão instaladas.

Cada unidade de geração tem uma potência instalada de 85 MW. Admitiu-se que com a instalação de quatro das seis unidades de geração, tem-se a totalidade da energia assegurada atribuída à usina, disponível para o sistema. Desta forma, com a instalação da quarta unidade, 
já se pode contar com toda a energia assegurada da usina para efeito de lastro para contratos de compra e venda de energia e participação no MRE.

A Figura[5.1] traz a ordenação temporal dos ciclos da usina hidrelétrica prototipada.

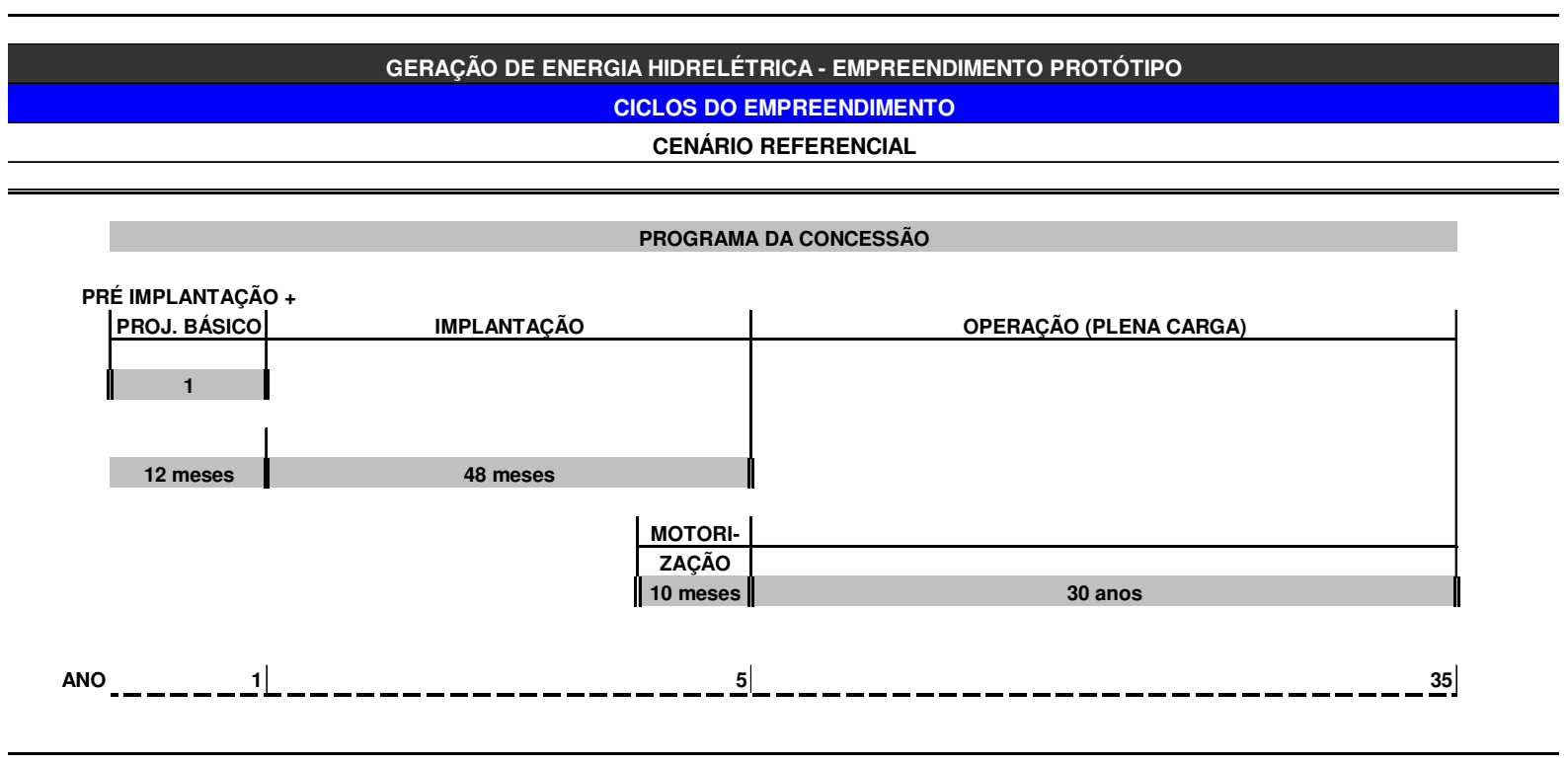

Figura 5.1 - Ciclos do Empreendimento Protótipo

A capacidade instalada da usina protótipo será de $510 \mathrm{MW}$, composta por seis unidades de geração com potência instalada de $85 \mathrm{MW}$ cada. As usinas concedidas após a publicação da lei 10.848 são, na sua maioria, usinas de pequeno porte com capacidade instalada média de 158 MW. Contudo, optou-se, no protótipo, por uma capacidade sensivelmente superior à média das usinas concedidas nos leilões, por considerar-se que, em uma usina de maior porte, a discussão acerca da estratégia de funding, de comercialização de energia e dos riscos do investimentos toma maior vulto.

Adotou-se como parâmetro para garantia física da usina, 293 MW médios, valor obtido multiplicando-se a potência instalada da usina protótipo pela média ponderada do fator [Garantia Física/Potência Instalada] das usinas concedidas nos leilões de dez/05 e out/06.

A energia assegurada é de $2.569 \mathrm{GWh}$, valor obtido multiplicando-se a Garantia Física pelo número de horas de um ano. A Tabela[5.1] resume os dados ora descritos. 


\begin{tabular}{|c|c|c|c|}
\hline POTÊNCIA INSTALADA & 510 & MW & \\
\hline UNIDADES GERADORAS & 6 & & Mês de Entrada em Operação Comercial \\
\hline UG1 & 85 & MW & 50 \\
\hline UG2 & 85 & MW & 52 \\
\hline UG3 & 85 & MW & 54 \\
\hline UG4 & 85 & MW & 56 \\
\hline UG5 & 85 & MW & 58 \\
\hline UG6 & 85 & MW & 60 \\
\hline Fator de Potência & 0,575 & & \\
\hline GARANTIA FISICA & 293 & MW & \\
\hline ENERGIA ASSEGURADA & 2.569 & GWh & \\
\hline
\end{tabular}

Tabela 5.1 - Características Gerais da UHE Protótipo

\section{Inserção de Mercado do Empreendimento}

Como já mencionado anteriormente, cabe ao empreendedor decidir qual o percentual de sua energia destinará ao ACR, ao ACL e, eventualmente, qual parcela da energia assegurada ficará propositadamente descontratada.

A opção pela manutenção de estoque de energia assegurada descontratada, além do percentual de perdas, poderia se dar por duas razões: (i) amenizar a exposição no mercado de curto prazo em períodos de hidrologia crítica ou após possível evento de revisão da energia assegurada da usina (ii) por postura especulativa do empreendedor, que manteria parcela descontratada da energia assegurada, visando liquidá-la ao PLD.

Entende-se que os resultados no ACR e ACL que seriam renunciados, se fosse admitido estoque de energia assegurada descontratada, superariam os custos evitados em períodos de hidrologia crítica e eventuais ganhos com posição especulativa no mercado de curto prazo. Por tal consideração, no cenário referencial, considerou-se a estratégia de contratação da totalidade da energia assegurada descontadas as perdas de transmissão, em detrimento da alternativa de manutenção de estoque descontratado. 
A estratégia de divisão da energia assegurada entre o ACR e ACL, no cenário referencial, reflete o padrão de decisão dos empreendedores hidrelétricos nos leilões de dez/05 e out/06. Nestes dois leilões, em média $97 \%$ da energia assegurada atribuída às novas usinas hídricas foi destinado à comercialização no ACR. Considerando que os 3\% restantes referem-se à parcela reservada para cobertura das perdas de energia na transmissão, entre a barra da usina e o centro de gravidade do subsistema, concluí-se que a estratégia de comercialização dos empreendimentos concedidos em dez/05 e out/06 foi a contratação integral do lastro da usina no ACR.

De forma a refletir tal padrão de decisão, no empreendimento protótipo, na condição do cenário referencial, 97\% da energia será comercializada no ACR e 3\% representam reserva para cobertura de perdas na transmissão. A discussão acerca da estratégia de divisão dos contratos no ACR e ACL será aprofundada na seção de análise de riscos.

No cenário referencial, a energia efetivamente gerada pela usina é igual à sua energia assegurada. De forma análoga, foi admitido que a energia gerada pelo sistema hídrico é igual à sua energia assegurada ao longo de todo ciclo de análise, de modo que não serão geradas, no cenário referencial, quaisquer transações no MRE e no mercado de curto prazo, ocasionadas por déficits e créditos proveniente de geração inferior ou superior à assegurada. Apenas quando da análise de risco, serão admitidas posições aleatórias da variável quantidade de energia, de forma que, em cada ano, serão verificadas posições deficitárias ou superavitárias no mercado de curto prazo.

Os CCEAR's firmados pelo empreendedor estabelecem o início do suprimento no mês 50 do ciclo de análise, ou quatro anos e dois meses após a realização do leilão de concessão do aproveitamento hidrelétrico. Como a completa implantação da usina só se dá no mês 60 e a completa formação do lastro de energia assegurada apenas a partir do mês 55, com a instalação da quarta máquina, o empreendedor adquire a energia complementar para cobertura dos CCEAR's, entre os meses 50 e 55, no mercado de curto prazo, ao PLD.

Antes da motorização de base da usina, o regulador permite que o empreendedor adquira a energia para cumprimento de seus contratos no mercado de curto prazo, sem penalizá-lo por falta de lastro. 
O preço de energia utilizado como referência para comercialização de energia nova no ACR foi 125 [R \$ base/MWh ${ }^{58}$, em alusão ao preço máximo definido para energia hídrica no leilão de out/06. Admitiu-se, como base para o cenário referencial, preço próximo do teto para o segundo leilão e não a média dos preços negociados pelos empreendimentos concedidos, uma vez que a crítica ao limite de preço fixado pelo MME é um dos objetivos desta dissertação. O preço de energia nos CCEAR's é reajustado anualmente respeitando a evolução do IPCA.

Para os preços das trocas de energia no MRE, fixou-se como valor referencial, a tarifa vigente ao longo do ano de 2006, de 7,25 [R $\$$ base/MWh], que reflete os custos de operação e manutenção, acrescidos dos valores pagos pelos geradores a título de compensação financeira pelo uso dos recursos hídricos. Admitiu-se que o preço da energia no MRE cresce, em valores correntes, respeitando a evolução do IPCA.

Ainda que não se tenha admitido transações no ACL no cenário referencial, para estudos de sensibilidade, considerou-se, como referência de preço da energia no ACL, 105 [R\$ base/MWh], preço teto verificado no leilão realizado pela Associação Brasileira de Grandes Consumidores Industriais de Energia e Consumidores Livres (ABRACE), em dez/06, para a compra de energia para os anos de 2007 e 2008. Admitiu-se que o preço da energia no ACL cresce, em valores correntes, respeitando a evolução do IPCA.

Como preço, no cenário referencial, para a energia comercializada no mercado de curto prazo, admitiu-se PLD de 62 [R \$ base/MWh], preço igual ao valor médio verificado em 2006 (ponderado pelo consumo verificado em cada submercado de energia - Norte, Sul, Sudeste/Centro-Oeste e Nordeste). Admitiu-se, também, preservação do valor do PLD, em moeda da base, ao longo de todo período de análise.

Apesar dos parâmetros de inserção de mercado do empreendimento terem sido arbitrados, no cenário referencial, de maneira discreta, serão objeto de análise considerando flutuação dispersa quando da análise de riscos de efeitos cruzados.

\footnotetext{
${ }^{58}$ Toda menção de valor monetário, quando não especificada em contrário, faz referência à moeda da data base da análise - dez/06 [R \$ base]. Admite-se o IPCA, como índice de perda de poder de compra da moeda na economia. Assim, todo componente de custo e preço que evolui conforme IPCA terá seu valor preservado em $[R \$$ base], ao longo do ciclo de análise. De outro lado, componentes que evoluem segundo parâmetros distintos terão seu valor em [R $\$$ base], ao longo do ciclo de análise, calculado considerando o descolamento entre seu índice de evolução e o IPCA.
} 
As informações acima apresentadas estão sintetizadas na Tabela[5.2].

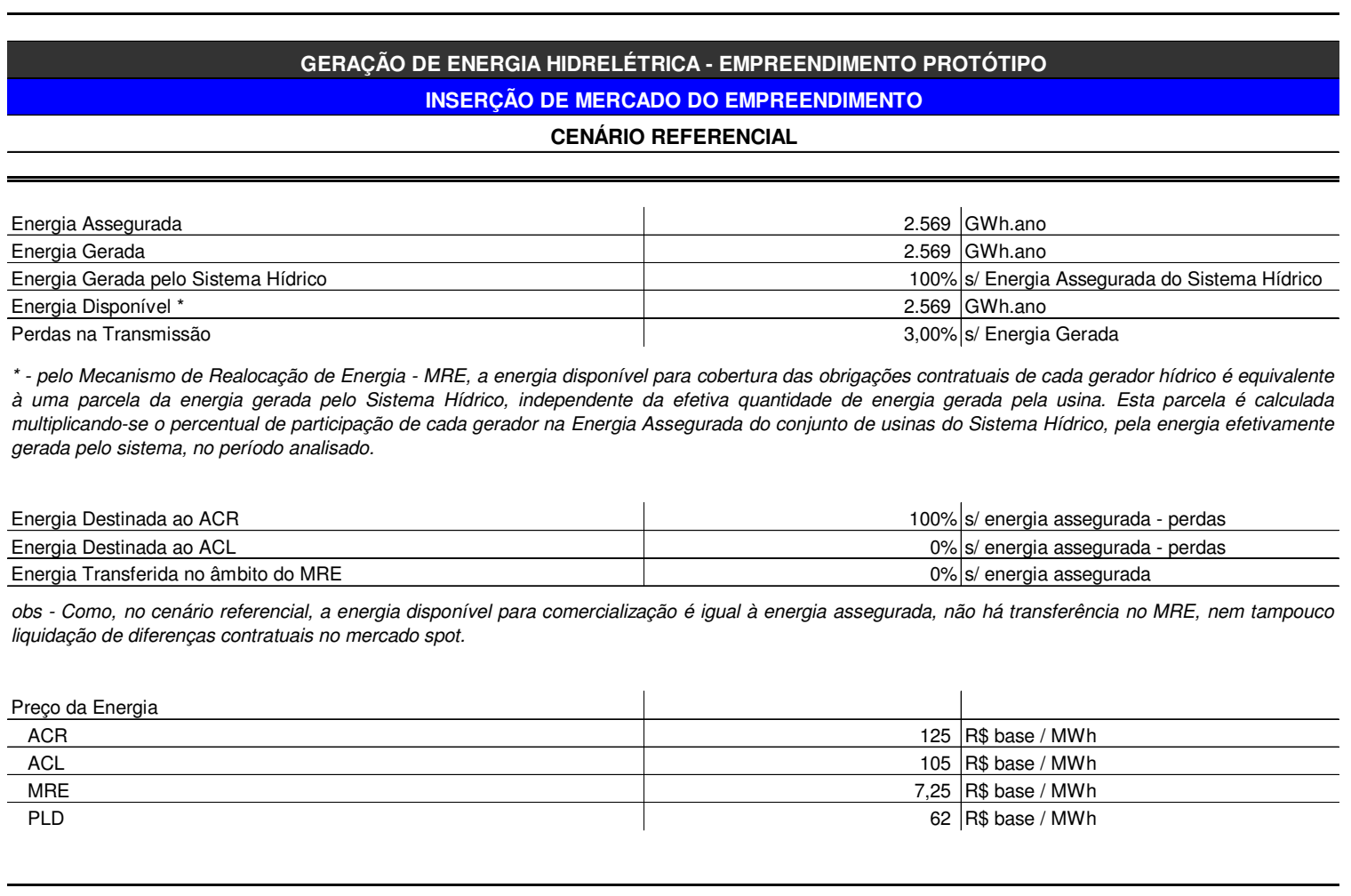

Tabela 5.2 - Inserção de Mercado do Empreendimento

\section{Contas de Implantação do Empreendimento}

As contas do período de implantação foram divididas em dois grupos: despesas préoperacionais e custos de obra.

As despesas pré-operacionais reúnem as contas com estudos, desapropriações, consultorias, seguros, despesas legais, programas ambientais e despesas administrativas da SPE no período de implantação.

Os custos de obra consideram os custos associados diretamente à construção e estão divididos em quatro grupos: projeto e engenharia, obras civis, procurement - conta que abarca os custos das atividades de compra, inspeção, diligenciamento, recebimento, manuseio, montagem e instalação de equipamentos eletromecânicos - e sistema de transmissão - em referência à subestação e linha de transmissão de uso restrito da central geradora. 
Foi admitido como parâmetro para o total das contas do período de implantação, 3.224 [R\$ base mil /MW], média ponderada do Custo Unitário de Implantação da amostra de empreendimentos listados no ANEXO A. Deste total, 10\% foram considerados despesas préoperacionais e, o restante, custos de obra.

As despesas pré-operacionais estão distribuídas de forma concentrada no primeiro ano de análise $-50 \%$ dos custos ocorrem no ano 1 e os $50 \%$ restantes estão distribuídos igualmente nos $\operatorname{anos} 2,3$ e 4 . Os custos de obra, por sua vez, estão divididos entre os 5 anos de construção, segundo um cronograma padrão de empreendimentos do setor que considera maior incidência de custos nos anos intermediários do programa de implantação, conforme tabela [5.3].

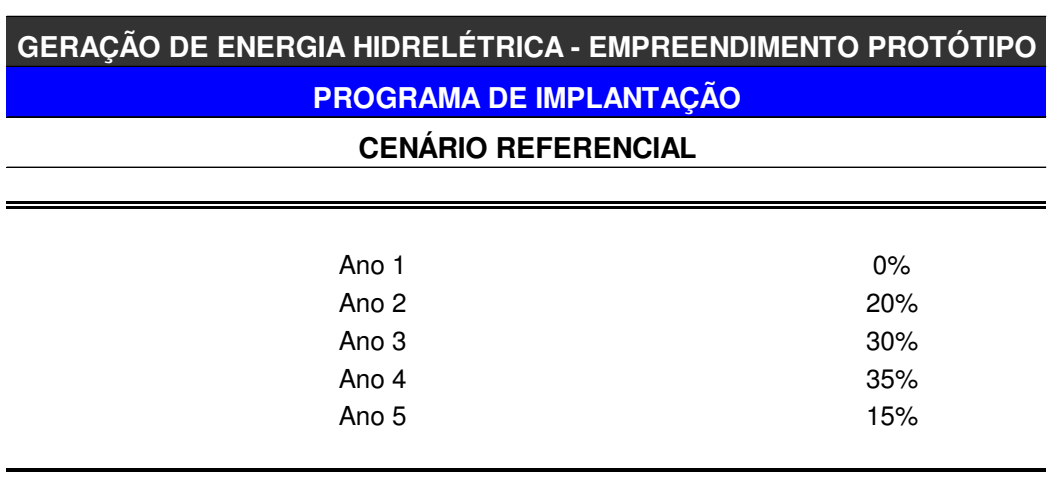

Tabela 5.3 - Programa de Implantação

Admitiu-se como índice de evolução dos custos de implantação, índice denominado, nesta dissertação, Índice Setorial da Construção (ISC). No cenário referencial, na falta de indicadores específicos para obras no setor, foi arbitrada evolução do ISC aderente à evolução admitida para o IPCA, conforme indicado em seção adiante.

A Tabela[5.4] traz os valores, no cenário referencial, das despesas pré-operacionais e dos custos de obra. 


\begin{tabular}{|c|c|c|c|}
\hline \multicolumn{4}{|c|}{ GERAÇÃO DE ENERGIA HIDRELÉTRICA - EMPREENDIMENTO PROTÓTIPO } \\
\hline \multicolumn{4}{|c|}{ CONTAS DE IMPLANTAÇÃO } \\
\hline \multicolumn{4}{|c|}{ CENÁRIO REFERENCIAL } \\
\hline CUSTO IMPLANTAÇÃO UNITÁRIO & cimpl & 3.224 & $\mathbf{R} \$$ base $\mathrm{mil} / \mathrm{MW}$ \\
\hline DESPESAS PRÉ-OPERACIONAIS & preimpl & $10 \%$ & s/ cimpl \\
\hline & $\%$ s/preimpl & $R \$$ base mil / MW & $R \$$ base mil \\
\hline Estudos Preliminares & $10 \%$ & 32 & 16.442 \\
\hline Desapropriações & $15 \%$ & 48 & 24.664 \\
\hline Despesas legais & $15 \%$ & 48 & 24.664 \\
\hline Consultorias & $15 \%$ & 48 & 24.664 \\
\hline Seguros & $15 \%$ & 48 & 24.664 \\
\hline Custos ambientais & $20 \%$ & 64 & 32.885 \\
\hline Outros & $10 \%$ & 32 & 16.442 \\
\hline Total & $100 \%$ & 322 & 164.424 \\
\hline CUSTOS DE OBRA & cob & $90 \%$ & s/ cimpl \\
\hline & $\%$ s/ cimpl & $R \$$ base mil / MW & $R \$$ base mil \\
\hline Projeto & $5 \%$ & 145 & 73.991 \\
\hline Procurement & $40 \%$ & 1.161 & 591.926 \\
\hline Obras Civis & $40 \%$ & 1.161 & 591.926 \\
\hline Sistema de Transmissão & $15 \%$ & 435 & 221.972 \\
\hline Total & $100 \%$ & 2.902 & 1.479 .816 \\
\hline
\end{tabular}

Tabela 5.4 - Custos de Implantação

\section{Funding do Empreendimento}

A equação de fundos do empreendimento será composta por recursos provenientes de quatro fontes distintas, a saber: (i) recursos próprios do concessionário, a serem aportados no empreendimento via conta de capital; (ii) recursos do programa de financiamento a empreendimentos do BNDES; (iii) recursos captados via emissão pública de debêntures e (iv) recursos gerados na operação do empreendimento, na venda de energia, durante o período em que as unidades de geração entram gradualmente em operação. $\mathrm{O}$ capital aportado pelo empreendedor no empreendimento será equivalente ao volume de recursos necessário para fechar a equação de fundos do empreendimento, após ingresso dos recursos provenientes das fontes (ii), (iii) e (iv).

No cenário referencial, $85 \%$ do custo de obra, ou 76,5\% do custo de implantação do empreendimento, são sustentados com recursos de terceiros, providos por BNDES e investidores nas debêntures, na proporção de 50\% cada. A totalidade das despesas préoperacionais, bem como o montante de recursos para fechar a equação de fundos do 
empreendimento, no ciclo de implantação, provêm do empreendedor e, em pequena monta, da operação do empreendimento no período de motorização da usina.

\section{- BNDES}

$\mathrm{O}$ apoio do BNDES às concessionárias de geração hidrelétrica pode cobrir até, aproximadamente, $70 \%$ do orçamento de implantação. Contudo, no cenário referencial, admitiu-se a captação de um montante equivalente a $42,5 \%$ do custo de obra.

Os recursos ingressam no empreendimento seguindo cronograma pari-passu ao programa de implantação. As condições do financiamento provido pelo BNDES estão previstas em contrato de concessão de crédito, travado entre a SPE e o BNDES, que, entre outros, estabelece período de carência para pagamento de juros e principal de seis meses, após a entrada em operação comercial da primeira unidade de geração, e período de amortização de 14 anos.

O crédito divide-se entre as modalidades direta e indireta na proporção de 50\%. Os juros são formados por TJLP mais spread de 3,5\% para operação direta e 4,5\% para operação indireta, sendo 2,5\%, estimativa do spread do BNDES, e 2,0\%, estimativa dos juros cobrados pela instituição repassadora do crédito. O valor arbitrado para a TJLP, ao longo de todo o horizonte de análise, foi 3,5\% ao ano, efetivo acima do IPCA (aproximadamente 6,5\% ao ano, em valores nominais, considerando IPCA verificado em 2006). Somam-se aos juros descritos, $0,20 \%$ sobre o valor da operação, a título de comissão de estudo, pago sobre o total do crédito, no momento do primeiro desembolso.

Destaca-se que a divisão do crédito, em proporções iguais entre as modalidades direta e indireta, corresponde à configuração usualmente preferida pelo BNDES que, na modalidade indireta, substitui o risco de crédito do tomador de recursos pelo risco de crédito da instituição repassadora.

Como garantia do pagamento da dívida, o banco exige a constituição e manutenção de conta reserva com recursos equivalentes a 3 meses de amortização e juros da dívida, mais o 
suficiente para cobertura de 30 dias de contas operacionais - incluídas custos de operação e manutenção, impostos, encargos setoriais e despesas de administração.

O banco exige também o atendimento ao ICSD de 1,3 - o ICSD é calculado dividindo-se o caixa disponível para pagamento do serviço da dívida, pelo serviço da dívida, conforme descrito em nota no capítulo 4. Como apenas $42,5 \%$ do valor de implantação são cobertos com recursos do BNDES, o índice de cobertura do serviço da dívida com o BNDES, no protótipo, é atendido com folga.

As condições acima descritas estão resumidas na Tabela[5.5].

\begin{tabular}{|c|c|c|}
\hline \multicolumn{3}{|c|}{ GERAÇÃO DE ENERGIA HIDRELÉTRICA - EMPREENDIMENTO PROTÓTIPO } \\
\hline \multicolumn{3}{|c|}{ FUNDING - BNDES } \\
\hline \multicolumn{3}{|c|}{ CENÁRIO REFERENCIAL } \\
\hline BNDES & $42,50 \%$ & s/ custo de obra \\
\hline Total do Crédito & 616.590 & $\mathrm{R} \$$ mil da base \\
\hline Prazo de Carência & 56 & meses \\
\hline Prazo de Amortização & 14 & anos \\
\hline \multicolumn{3}{|l|}{ Custo do Financiamento } \\
\hline Op. Direta / Op. Indireta & $50 \% / 50 \%$ & \\
\hline Taxa Básica & TJLP & \\
\hline Limite p/ Capitalização da TJLP* & $6,00 \%$ & ao ano \\
\hline Spread BNDES Op. Direta & $3,50 \%$ & ao ano \\
\hline Spread BNDES Op. Indireta & $2,50 \%$ & ao ano \\
\hline Spread Agente Repassador & $2,00 \%$ & ao ano \\
\hline Spread Total & $4,00 \%$ & ao ano \\
\hline Comissão de Estudo & $0,20 \%$ & s/ valor do crédito \\
\hline \multicolumn{3}{|l|}{ Outras Condições } \\
\hline Conta Reserva & \multicolumn{2}{|c|}{3 meses de dívida +1 mês de Operação e Manutenção } \\
\hline Índice de Cobertura do Serviço da Dívida & \multicolumn{2}{|c|}{ maior ou igual a 1,3} \\
\hline
\end{tabular}

Tabela 5.5 - Condições do Financiamento do BNDES

- Títulos de Investimento em Energia Elétrica (TIEE)

Para efeito do protótipo, os TIEE são títulos originados da securitização dos direitos emergentes da concessão ${ }^{59}$, resultantes de processo de emissão pública.

59 Os contratos de concessão permitem que o empreendedor utilize os direitos emergentes da concessão como instrumento de garantia em contratos de financiamento. Os direitos emergentes da 
A equação de fundos do protótipo considerará dois ciclos de emissão pública de debêntures, a dos TIEE-A1 e a dos TIEE-A2. À emissão dos TIEE-A1, dá-se o nome, nesta dissertação, de emissão não performada, uma vez que a emissão está lastreada no compromisso de construção e não na usina já constituída. À emissão dos TIEE-A2, chamou-se emissão performada, porque ocorre após a completa implantação do ativo.

Os TIEE-A1 são destinados exclusivamente à cobertura dos custos de obra e devem suprir, no cenário referencial, cerca de $42,5 \%$ deste montante. O volume da emissão será definido a partir das necessidades de recursos para obras, juros e custos incorridos no processo de emissão, sem considerar o fluxo de despesas pré-operacionais, cuja cobertura será atribuição do empreendedor.

A integralização dos TIEE-A1 ocorrerá em quatro séries anuais, respeitando-se o programa anual de implantação do empreendimento. A primeira série deverá ser integralizada no ano 2 do ciclo de análise.

Os juros serão pagos em períodos mensais, sem carência, e calculados sobre o valor de face dos títulos ativos, cuja atualização far-se-á em períodos anuais, pelo IPCA ${ }^{60}$. Os títulos oferecem remuneração à taxa de $10 \%$ ao ano, efetiva acima do $\operatorname{IPCA}^{61}$. O principal é pago em uma única parcela no ano 6 do ciclo de análise, ano subseqüente à última série de integralização.

Os TIEE-A1 serão resgatados com recursos captados em uma nova emissão, denominada, nesta dissertação, emissão performada. Os títulos da segunda emissão, TIEE-A2, serão

concessão contemplam os contratos de compra e venda de energia firmados pelo empreendedor, os ativos vinculados à usina e o direito de exploração do aproveitamento. Na hipótese de uma eventual execução do instrumento de garantia, o Poder Concedente toma para si a concessão ou promove nova licitação do aproveitamento. Aos credores, o Poder Concedente repassará os recursos devidos até o limite do valor dos ativos da usina não depreciados. Caso o montante supere o valor devido aos credores, o excedente é devolvido ao concessionário.

${ }^{60}$ Como os juros são pagos em períodos mensais e o valor de face dos títulos é corrigido em períodos anuais, os juros são decrescentes, em [R $\$$ base], ao longo de um ano, em função da perda inflacionária. Por este motivo, a taxa interna de retorno do investidor nos TIEE-A1, resultará pouco inferior ao valor absoluto dos juros oferecidos.

${ }^{61}$ A remuneração dos títulos foi arbitrada com base na remuneração apurada em processos de bookbuilding, para debêntures emitidas por empresas integradas do setor elétrico no ano de 2006. Em média, emissões com prazo total de 5 anos ofereceram remuneração de $104 \%$ do CDI. Considerando valores de dezembro de $2006,104 \%$ do CDI equiparam-se à aproximadamente IPCA + $10 \%$, valor arbitrado como parâmetro para remuneração dos TIEE-A1. 
subscritos e integralizados em uma única série, de valor igual ao valor necessário para resgate da totalidade dos TIEE-A1. Os TIEE-A2 são resgatados a partir do ano subseqüente ao ano da integralização, em 15 parcelas anuais iguais.

A taxa de remuneração dos TIEE-A2 foi admitida inferior à oferecida pelos TIEE-A1, em função da não necessidade de cobertura dos riscos de construção. A remuneração dos TIEEA2 é formada por IPCA+ juros fixos de 6,5\% ao ano + prêmio de participação de 6,5\% sobre a receita operacional líquida do empreendimento ${ }^{62}$. A expectativa é que os parâmetros acima arbitrados levem a taxa de retorno dos TIEE-A2, para uma configuração de preços de energia e inflação aderente à condição arbitrada no cenário referencial, ao patamar aproximado de 8,5\% ao ano, efetivo acima do IPCA. Este valor representa pequeno incremento em relação à remuneração oferecida por títulos públicos do governo federal indexados ao $\operatorname{IPCA}^{63}$, com prazo de resgate de aproximadamente 15 anos.

Os TIEE-A2 oferecem pagamento de juros mensais, calculados sobre o valor de face do montante de títulos por resgatar, corrigido pelo IPCA. Como a correção do valor de face dos títulos se dá em períodos anuais e os juros são pagos em períodos mensais, também se verifica o efeito da perda inflacionária na remuneração do investidor.

A consideração da rolagem da dívida, com emissão dos TIEE-A2 para resgate dos TIEE-A1, é estratégia ainda pouco utilizada em empreendimentos hidrelétricos desenvolvidos no Brasil. Mais comum é que os recursos necessários para implantação sejam captados seguindo um regime aderente ao programa de implantação e devolvidos, a partir do primeiro ano de operação plena do empreendimento, com recursos exclusivamente gerados na própria operação.

Entretanto, a rolagem permite ao empreendedor postergar a amortização da dívida contraída no período de implantação e reduzir seu custo financeiro, na medida em que o custo da nova dívida não mais incorpora contrapartida para cobertura dos riscos de construção. A rolagem

62 O prêmio, calculado sobre a receita operacional líquida do empreendimento [ROL], varia proporcionalmente ao volume de títulos ativos. Quando 100\% dos títulos estão ativos, o prêmio é de $6,5 \%{ }^{*}[\mathrm{ROL}]$; no ano subseqüente à primeira amortização, o prêmio é de $(1-1 / 15)^{*} 6,5 \%{ }^{*}[\mathrm{ROL}]$; no ano subseqüente à segunda amortização, o prêmio é de $(1-2 / 15)^{*} 6,5 \%{ }^{*}[R O L]$, no ano subsequente à enésima amortização, o prêmio é de $(1-n / 15)^{*} 6,5 \%{ }^{*}[R O L]$.

${ }^{63}$ NTN-B, emitidas em 2000, com prazo de resgate de 15 anos a partir de 2007, e remuneração fixa aproximada de 7,7\% ao ano, efetiva acima do IPCA (disponível para compra, em dezembro de 2006, no Tesouro Direto). 
da dívida contribui para intensificar o fluxo de recursos livres no empreendimento, nos primeiros anos de caixa operacional, antecipando retornos e, consequentemente, elevando a taxa de remuneração dos recursos do empreendedor, imobilizados no empreendimento.

Nesta dissertação, considerou-se apenas um único ciclo de rolagem da dívida, com resgate da emissão não performada, através da emissão performada, com prazo de amortização de 15 anos. Desta forma, ao final do ano 21 do horizonte de análise, toda a dívida do projeto terá sido liquidada, restando ainda 14 anos de concessão, período no qual todo o resultado operacional comporá o fluxo de retorno do empreendedor.

A Tabela[5.6] resume as condições das emissões ora descritas. 
GERAÇÃO DE ENERGIA HIDRELÉTRICA - EMPREENDIMENTO PROTÓTIPO

FUNDING - TITULOS DE DIVIDA

CENÁRIO REFERENCIAL

\section{EMISSAO NAO PERFORMADA}

\begin{tabular}{l|c|c}
\hline \hline \multicolumn{2}{l}{} \\
\hline \hline TIEE A1 - Base para Cálculo do Valor da Emissão & $42,5 \% \mathrm{~s} /$ custo de obra+ custos emissão + juros durante carência \\
\hline TIEE A1 - Valor da Emissão & 738.660 & $\mathrm{R} \$$ base mil \\
\hline & & \\
Condições [TIEE - A1] - Prazos / Integralização e Resgate & 4 & do ano 2 ao ano 5 \\
\hline Séries Anuais - Integralização & 6 & \\
\hline Ano Início - Resgate & 6 & \\
\hline Ano Fim - Resgate & 1 & no ano 6 \\
\hline Prazo de Resgate (anos) & & \\
\hline & & \\
Condições [TIEE - A1] - Juros e Prêmio & IPCA & \\
\hline base & $10,0 \%$ & ao ano, acima do IPCA \\
\hline juros & &
\end{tabular}

\section{EMISSAO PERFORMADA}

\begin{tabular}{l|c|c}
\hline TIEE A1 - Base para Cálculo do Valor da Emissão & necessidade resgate TIEE A1 \\
\hline TIEE A1 - Valor da Emissão & 738.660 & R $\$$ base mil \\
\hline & & \\
Condições [TIEE - A2] - Prazos / Integralização e Resgate & 1 & no ano 6 \\
\hline Séries Anuais - Integralização & 7 & \\
\hline Ano Início - Resgate & 21 & \\
\hline Ano Fim - Resgate & 15 & do ano 7 ao ano 21 \\
\hline Prazo de Resgate (anos) & & \\
\hline 6,67\% dos títulos são resgatados anualmente, do ano 7 ao 21 & \\
\hline \\
Condições [TIEE - A2] - Juros e Prêmio & & \\
\hline \multicolumn{2}{|l}{} \\
\hline base & IPCA & \\
\hline juros & $6,50 \%$ & ao ano, acima do IPCA \\
\hline prêmio & $6,50 \%$ & s/ Receita Operacional Líquida \\
\hline
\end{tabular}

CUSTOS DA EMISSAO

\begin{tabular}{l|r|l}
\hline \hline \multicolumn{2}{|c|}{} & \\
\hline Custos no Momento da Emissão - Emissões 1 e 2 & $1,00 \%$ s/ Valor da Emissão \\
\hline Estruturação & $0,20 \%$ s/ Valor da Emissão \\
\hline Contas Gerais & $2,00 \%$ s/ Valor da Emissão \\
\hline Colocação & & \\
\hline Custos Anuais & & \\
\hline Emissão 1 - Não performada & 250 & $\mathrm{R} \$$ base mil/ano \\
\hline Custos Anuais & & \\
\hline Emissão 2 - Performada & $250 \mathrm{R} \$$ base mil/ano \\
\hline Custos Anuais & \\
\hline
\end{tabular}

Tabela 5.6 - Condições das Emissões dos Títulos de Dívida

A Figura[5.2] apresentada, sintetiza a distribuição temporal do funding do BNDES e das emissões de títulos de dívida performada e não performada. 


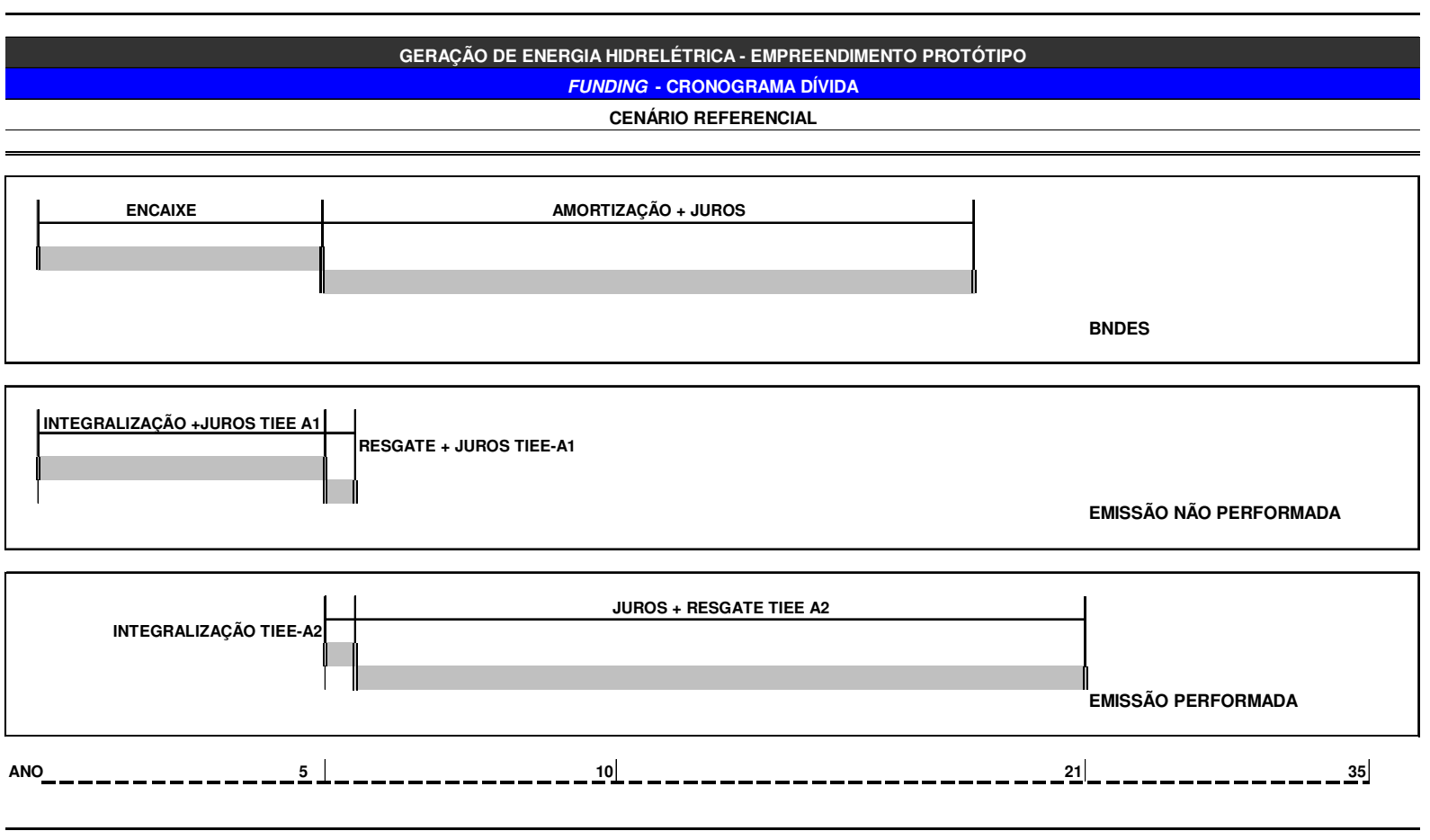

Figura 5.2 - Cronograma de Funding

\section{Contas de Operação}

As contas do ciclo operacional foram divididas nos seguintes grupos:

- Impostos sobre Receita Bruta: foram considerados os impostos federais PIS e COFINS, nas alíquotas de 1,65\% e 7,60\%, respectivamente. Para base de cálculo do PIS e COFINS, admitiu-se a Receita Operacional Bruta reduzida dos encargos de depreciação e custo de serviços prestados por terceiros (Operação e Manutenção, e Seguros). Adicionalmente, por simplificação, admitiu-se que o imposto sobre movimentação financeira CPMF, ainda que seja incidente sobre as saídas de caixa, será calculado aplicando-se a alíquota de 0,38\% sobre a Receita Operacional Bruta auferida pela SPE.

- Encargos Setoriais ${ }^{64}$ :

${ }^{64}$ Encargos setoriais previstos nos contratos de concessão de uso do bem público, para usinas concedidas no primeiro leilão de energia nova realizado em dez/05, exceto CDE, CCC e PROINFA. A CDE, CCC e PROINFA são encargos recolhidos apenas pelos agentes que comercializam energia diretamente com consumidores finais.

Para os consumidores do mercado cativo, estes encargos são, portanto, recolhidos pela concessionária de distribuição. Para os consumidores livres e auto-produtores, estes encargos são recolhidos ou pelas concessionárias de transmissão ou pelas concessionárias de distribuição, caso estes consumidores estejam ligados diretamente na rede básica ou na rede de distribuição. 
○ Taxa de Fiscalização de Serviços de Energia Elétrica (TFSEE): encargo destinado à cobertura das despesas incorridas pelo regulador. O valor é obtido pela Equação[5.1]:

TFSEE $=0,5 \% * B E N *$ pot.inst Equação[5.1]

Onde:

BEN - Benefício Econômico ANEEL. Utilizado valor vigente em 2006, 331,33 $[R \$ / k W](A N E E L, 2005 f)$.

pot.inst - Potência Instalada da usina, $500 \mathrm{MW}$.

- Taxa de Pesquisa e Desenvolvimento (P\&D): encargo que obriga as concessionárias de serviços públicos do setor elétrico a aplicar anualmente, o montante de, no mínimo, $0,75 \%$ de sua receita operacional líquida em pesquisa e desenvolvimento do setor elétrico e, no mínimo, $0,25 \%$ em programas de eficiência energética no uso final. Os recursos são destinados ao Ministério da Ciência e Tecnologia, Fundo Nacional de Desenvolvimento Científico e Tecnológico, ao MME e aos agentes, a serem aplicados em projetos aprovados pela ANEEL.

- Compensação Financeira pelo Uso de Recursos Hídricos (COFURH): valor destinado à compensação dos municípios afetados pela perda de terras produtivas, ocasionada por inundação de áreas na construção de reservatórios de usinas hidrelétricas. Do montante arrecadado mensalmente a título de compensação financeira, $45 \%$ se destinam aos Estados, 45\% aos Municípios, 4,4\% ao Ministério de Meio Ambiente, 3,6\% ao MME, e 2\% ao Ministério de Ciência e Tecnologia. A COFURH é obtida pela Equação[5.2]:

COFURH $=6,75 \% * T A R * G H \quad$ Equação[5.2]

Onde:

TAR - Tarifa Atualizada de Referência. Utilizado valor vigente em 2006 de 55,94 [R\$/MWh] (ANEEL,2005b).

GH - Energia Gerada em MWh.

○ Uso do Bem Público (UBP): no modelo anterior à lei 10.848, as novas concessões de aproveitamentos hídricos eram outorgadas ao empreendedor que propusesse o maior UBP. No novo modelo, o critério de julgamento passou a utilizar como parâmetro o preço da energia destinada ao mercado cativo e, não mais, o UBP. Entretanto, o MME manteve a exigência de pagamento do UBP, que passou a ser calculado pela Equação[5.3]: 
$U B P=(N H A / 100) * V P * G F \quad$ Equação[5.3]

Onde:

NHA - número de horas no ano, admitido 8.760.

VP - Valor Percentual, situado entre 0,5 e 1, que reflete a atratividade econômica do aproveitamento concedido, calculado considerando a relação entre a tarifa de referência do empreendimento e o custo marginal de referência do leilão em que a concessão é outorgada. Quanto mais próximo de 1, maior a atratividade relativa do empreendimento, do contrário, quanto mais próximo de 0,5 menor a atratividade do empreendimento. Admitiu-se índice igual a 0,5 para cálculo do $U B P$.

GF - Garantia Física do empreendimento.

- Tarifa de Uso do Sistema de Transmissão (TUST): valor pago pelo gerador pelo uso do sistema de transmissão. Cabe ao gerador entregar a energia por ele produzida no centro de gravidade do subsistema do qual a usina faz parte. Os encargos de transmissão são assim repartidos entre geradores e distribuidores, os primeiro pagam pela energia que injetam no SIN, os segundos pagam pela energia que retiram do SIN, tendo como ponto de referência o Centro de Gravidade do subsistema.

Os valores de TUST atribuídos a cada usina hídrica do sistema oscilam dentro de um largo espectro. Como ordem de grandeza, os valores pagos pelas usinas hoje em operação estão entre 0,132 [R \$/kW.mês] e 9,806 [R \$/kW.mês] (ANEEL, 2006a). Definiu-se que o valor utilizado como base para a TUST, a ser pago pelo empreendimento protótipo, será próximo da moda dos valores verificados na resolução referida, aproximadamente 3 [R \$/kW.mês].

- Custo de Operação e Manutenção: os custos de operação e manutenção da usina foram arbitrados tomando como base o valor atribuído para energia nas trocas entre geradores hídricos, no âmbito do MRE. O valor da energia vigente no ano de 2006 foi de 7,25 [R\$ /MWh], valor considerado suficiente para cobertura dos custos de operação e manutenção e do COFURH. Considerando que o valor vigente da COFURH em 2006 é de 3,77 [R\$/MWh], o valor restante 3,61 [R\$/MWh] foi admitido como parâmetro de referência para o custo de operação e manutenção da usina hidrelétrica, durante todo o ciclo de operação. Admitiu-se que os custos de operação e manutenção evoluam seguindo índice setorial de operação e manutenção de usinas hidrelétricas, nesta dissertação, denominado ISEE. Ao ISEE, arbitrou-se, no cenário referencial, comportamento aderente ao do IPCA. 
- Despesas de Administração: as SPE's criadas para o desenvolvimento de empreendimentos de geração de energia hidrelétrica têm, em geral, ao longo do período de operação, corpo gerencial e equipe administrativa reduzidos. Admitiu-se como parâmetro de Despesas de Administração, o valor equivalente a 1,0\% da receita líquida do empreendimento.

- Programas Ambientais: admitiu-se que cerca de $1 \%$ da receita líquida do empreendimento é despendido anualmente no desenvolvimento e manutenção de programas de preservação ambiental e ações de cunho social previstas no RIMA do empreendimento.

- Seguros: arbitrou-se que o custeio das despesas com seguros, ao longo do período de operação, exija valores anuais equivalentes a $0,5 \%$ da receita líquida do empreendimento.

- Fundo para Reposição de Ativos (FRA): não estão embutidos no Custo de Operação e Manutenção do empreendimento dispêndios com reposição de ativos. De outro lado, arbitrou-se que serão reservados anualmente cerca de $0,5 \%$ do valor de implantação do empreendimento, em moeda da base, para eventuais reposição de ativos, que se façam necessárias ao longo do ciclo operacional.

- Impostos sobre Resultado: Imposto de Renda (IR) e Contribuição Social sobre o Lucro Líquido (CSLL), obtidos considerando alíquota total de 34\% sobre o caixa operacional do empreendimento reduzido de encargos financeiros e de depreciação ${ }^{65}$.

Os custos do ciclo operacional estão identificados na Tabela[5.7].

${ }^{65}$ Os encargos de depreciação foram calculados considerando o diferimento dos montantes despendidos no ciclo de implantação do empreendimento, a partir da data de entrada em operação comercial da usina, nos seguintes prazos: (i) 25 anos, para obras civis; (ii) 10 anos, para equipamentos, sistema de transmissão e serviços de montagem eletromecânica; (iii) 5 anos, para despesas pré-operacionais, projeto de engenharia e juros pagos durante a construção. 
GERAÇÃO DE ENERGIA HIDRELÉTRICA - EMPREENDIMENTO PROTÓTIPO

CONTAS DE OPERAÇÃO

CENÁRIO REFERENCIAL

\begin{tabular}{|c|c|c|}
\hline CUSTO OPERAÇÃO E MANUTENÇÃO & coper & $\mathbf{R} \$$ base / MWh \\
\hline \multicolumn{3}{|l|}{ OUTRAS DESPESAS } \\
\hline Despesas Administração & $1,0 \%$ & s/ receita líquida \\
\hline Programas Ambientais & $1,0 \%$ & s/ receita líquida \\
\hline Seguros & $0,5 \%$ & $\mathrm{~s} /$ receita líquida \\
\hline \multicolumn{3}{|l|}{ ENCARGOS SETORIAIS } \\
\hline (1) Índice COFURH & $6,5 \%$ & \\
\hline (2) Tarifa Anual de Referência - TAR & 56 & $\mathrm{R} \$$ base $/ \mathrm{MWh}$ \\
\hline (3) Compensação Financeira pelo Uso do Recurso Hídrico - COFURH & $(1)^{\star}(2)^{\star}($ En. Gerada $)$ & \\
\hline (4) Índice TFSEE & $0,50 \%$ & \\
\hline (5) Benefício Econômico ANEEL & 331 & $\mathrm{R} \$$ base $/ \mathrm{kW}$ \\
\hline (6) Taxa de Fiscalização Serviços de Energia Elétrica - TFSEE & $(4)^{\star}(5)^{\star}($ Pot. Inst. $)$ & \\
\hline (7) Pesquisa e Desenvolvimento - P\&D & $1,0 \%$ & s/ rec. líquida de PIS e COFINS \\
\hline (8) Tarifa de Uso do Sistema de Transmissão - TUST & 3 & $\mathrm{R} \$$ base / kW.mês \\
\hline (9) Uso do Bem Público - UBP & 1.606 & $\mathrm{R} \$$ base mil \\
\hline \multicolumn{3}{|l|}{ IMPOSTOS SOBRE FATURAMENTO } \\
\hline PIS & $1,65 \%$ & s/ receita bruta ajustada \\
\hline COFINS & $7,60 \%$ & $\mathrm{~s} /$ receita bruta ajustada \\
\hline CPMF & $0,38 \%$ & $\mathrm{~s} /$ receita bruta \\
\hline \multicolumn{3}{|l|}{ IMPOSTOS SOBRE FATURAMENTO } \\
\hline Imposto de Renda & $25 \%$ & s/ lucro líquido antes de IR e CSLL \\
\hline CSLL & $9 \%$ & s/ lucro líquido antes de IR e CSLL \\
\hline
\end{tabular}

Tabela 5.7 - Contas de Operação

\section{Cenário Macroeconômico}

Os parâmetros macroeconômicos presentes na análise estão associados às expectativas de comportamento de inflação e taxa de juros básica aplicada nos financiamentos providos pelo BNDES.

No modelo de análise, admitiu-se que o índice de inflação utilizado como referência para perda do poder de compra na economia é o IPCA. A escolha do IPCA deu-se, por ser este o indexador utilizado nos CCEAR's firmados entre geradores e empresas concessionárias de distribuição. Tendo por base o IPCA, todos os outros índices de inflação e juros utilizados na análise foram arbitrados, não pelo seu valor absoluto, mas pelo grau de descolamento em relação ao IPCA. 
Foi admitido que os custos de implantação do empreendimento evoluam segundo um índice específico, denominado, nesta dissertação, ISC, com descolamento nulo em relação ao IPCA, no cenário referencial. Para os custos com operação e manutenção admitiu-se evolução segundo índice específico, denominado, para efeito desta dissertação, ISEE, que tem, no cenário referencial, comportamento também aderente ao IPCA.

Os valores arbitrados para o IPCA, bem como para o descolamento entre IPCA e TJLP estão apresentados na Tabela[5.8] e foram arbitrados tendo como base comportamento histórico e as expectativas de mercado para os anos vindouros. A Tabela[5.8] traz ainda o padrão de taxa atratividade - $\underline{\text { tat }}$ setorial e o custo de oportunidade - $\underline{\text { cop }}$ admitidos na análise.

A tat é entendida como sendo o padrão que o empreendedor admite como piso de remuneração para investimento neste particular empreendimento. Como o empreendimento prototipado tenciona ser representativo de um amplo espectro de empreendimentos hidrelétricos, a taxa aqui utilizada é a taxa que, entende-se, seja indicativa do padrão de atratividade do setor para investimentos em empreendimentos hidrelétricos. O valor da tat setorial, admitido nesta análise, é de $12 \%$ ao ano, efetivo acima do IPCA (após impostos sobre resultado).

O $\underline{c o p}$ é a taxa que se arbitra para aplicações de risco desprezível na conjuntura econômica. Admitiu-se como referência, a taxa oferecida pelas Notas do Tesouro Nacional da Série B (NTN-B), com vencimento em 2024, indexadas ao IPCA. A remuneração admitida para estes títulos é de 7,7\% ao ano, efetiva acima do IPCA (NTN-B 150824 - disponível para compra em 28/12/2006 ${ }^{66}$ ). Assumiu-se que os rendimentos da aplicação nas NTN-B são tributados na alíquota média de $15 \%$. Desta forma, o custo de oportunidade, após tributação, resulta igual à taxa de $6,5 \%$ ao ano, efetiva acima do IPCA.

\footnotetext{
${ }^{66}$ Informação disponível em

http://www.tesouro.fazenda.gov.br/tesouro_direto/consulta_titulos/consultatitulos.asp
} 
GERAÇÃO DE ENERGIA HIDRELÉTRICA - EMPREENDIMENTO PROTÓTIPO

CENÁRIO MACROECONÔMICO ARBITRADO

CENÁRIO REFERENCIAL

\begin{tabular}{l|r}
\hline MOEDA DA ANÁLISE & $\begin{array}{l}\text { R\$ base (data da análise - dez/06) } \\
\text { Obs: Utilizado, como referência de perda de poder de compra da moeda na economia, o índice IPCA. }\end{array}$ \\
\hline Inflação Referencial - IPCA & $3,50 \%$ ao ano \\
\hline Inflação Contratos de Compra e Venda de Energia ACR e ACL & IPCA \\
\hline Inflação de Custos de Construção - ISC & $0 \%$ ao ano, acima do IPCA \\
\hline Inflação de Custos de Operação - ISE & $0 \% \mid$ ao ano, acima do IPCA \\
\hline TJLP & $3,50 \% \mid$ ao ano, efetiva, acima do IPCA \\
Taxa de Atratividade Setorial - tat & $12,0 \% \mid$ ao ano, efetiva, acima do IPCA \\
\hline Custo de Oportunidade - cop & $6,5 \%$ ao ano,efetiva, acima do IPCA \\
\hline
\end{tabular}

Tabela 5.8 - Cenário Macroeconômico 


\subsection{INDICADORES DA QUALIDADE DO INVESTIMENTO}

Após simulação das transações financeiras no ambiente do empreendimento protótipo, tendo lançado no modelo de análise o cenário macroeconômico, os parâmetros para equação de fundos no período de implantação e contas do período operacional do empreendimento, extraímos da análise os indicadores da qualidade do investimento.

Os indicadores da qualidade no cenário referencial refletem a melhor expectativa acerca do resultado econômico alcançado a partir da implantação e operação do empreendimento. Em outros termos, oferecem ao empreendedor a melhor informação acerca da capacidade de gerar renda do empreendimento.

Os indicadores utilizados na análise são:

1. Taxa Interna de Retorno $(T I R)$ - indica a capacidade máxima que o empreendimento tem de gerar rentabilidade, considerando-se o fluxo de investimentos $\left[\mathrm{I}_{\mathrm{k}}\right]$ que exige para girar e o fluxo de retorno $\left[\mathrm{R}_{\mathrm{k}}\right.$ ] que é capaz de devolver para o empreendedor (ROCHA LIMA JR., 1998). A $\underline{T I R}$ é calculada no conceito de taxa equivalente, uma vez que não se observam relações específicas entre posições de investimento com outras de retorno. O empreendedor perde poder de compra ao se imobilizar diante das necessidades do empreendimento, para se recobrar poder de compra, em um outro ciclo, diante do potencial de liberar recursos do empreendimento. A $\underline{T I R}$ deve ser lida como a taxa que remunera o investidor posicionado ao final do horizonte de análise, considerando que este aplica seus recursos no regime dos $\left[\mathrm{I}_{\mathrm{k}}\right]$ e retira seus recursos no regime dos $\left[\mathrm{R}_{\mathrm{k}}\right]$ (ROCHA LIMA JR., 1996). A taxa interna de retorno é aquela que satisfaz a Equação[5.4]:

$$
\sum_{k} \frac{I_{k}}{(1+T I R)^{k}}=\sum_{k} \frac{R_{k}}{(1+T I R)^{k}} \quad \text { Equação[5.4] }
$$

Na Equação[5.4]: [TIR] é a taxa interna de retorno; $\left[\mathrm{I}_{\mathrm{k}}\right]$ investimento no ano $\mathrm{k}$ e $\left[\mathrm{R}_{\mathrm{k}}\right]$ retorno no ano $\mathrm{k}$. 
A $\underline{T I R}$ auferida pelo empreendedor será, durante toda a rotina de análise, comparada à taxa de atratividade $-\underline{\text { tat }}$ e ao custo de oportunidade $-\underline{\text { cop }}$.

2. Prazo de Recuperação da Capacidade de Investimento (payback) - prazo em que o empreendedor recupera a massa de recursos que investiu. O payback será calculado considerando três conceitos, ou padrões de rentabilidade: (i) payback pri - prazo de recuperação dos recursos investidos em moeda da base - corrigidos segundo evolução do índice de inflação adotado como referência na análise; (ii) payback a cop - prazo de recuperação dos recursos investidos remunerados ao custo de oportunidade e (iii) payback a tat - prazo de recuperação dos recursos investidos remunerados à taxa de atratividade setorial. O payback, nos três conceitos, é aquele que satisfaz a Equação[5.5]:

$$
\sum_{k=1}^{p b c k} \frac{I_{k}}{(1+t)^{k}}=\sum_{k=1}^{p b c k} \frac{R_{k}}{(1+t)^{k}} \quad \text { Equação[5.5] }
$$

Na Equação[5.5]: $\left[\mathrm{I}_{\mathrm{k}}\right]$ é o investimento no ano k; $\left[\mathrm{R}_{\mathrm{k}}\right]$ é o retorno no ano $\mathrm{k}$ e [t] é a taxa de remuneração dos recursos investidos, utilizada para indicar a atratividade alternativa do empreendedor. [t] é igual a 0, na situação (i); igual à $\underline{c o p}$, na situação (ii) e igual à tat, na situação (iii).

3. Exposição Máxima (exp.max) - mede o nível de máxima exposição do empreendedor dentro do horizonte de análise, ou o volume máximo de investimentos imobilizados no empreendimento. O nível de exposição em um dado ano q, é calculado através da Equação[5.6]:

$$
E X P_{q}=\sum_{k=1}^{q}\left[I_{k} *(1+t)^{q-k}-R_{k} *(1+t)^{q-k}\right] \geq 0 \quad \text { Equação[5.6] }
$$

Na Equação[5.6]: $\left[\mathrm{I}_{\mathrm{k}}\right]$ é o investimento no ano k; [ $\left.\mathrm{R}_{\mathrm{k}}\right]$ é o retorno no ano k; [q] é o ano em que se calcula a exposição e [t] é a taxa de remuneração dos recursos investidos, utilizada para indicar a atratividade alternativa do empreendedor. Nesta dissertação, o nível de exposição será calculado considerando duas situações: (i) $\mathrm{t}=0 \mathrm{e}$, (ii) $\mathrm{t}=$ cop. 
exp.max $=\operatorname{MAX}_{q=1}^{n}\left(E X P_{q}\right) \quad$ Equação[5.7]

Na Equação[5.7], [n] é o último ano do horizonte de análise.

4. Curva de Formação da TIR - a taxa interna de retorno deve ser lida como a taxa que remunera os recursos investidos, para um investidor posicionado ao final do horizonte de análise, após a liberação, pelo empreendimento, da totalidade dos recursos $\left[\mathrm{R}_{\mathrm{k}}\right]$. Desta forma, a simples leitura deste indicador, de forma isolada, torna-se frágil em empreendimentos de longo prazo de maturação ao não permitir que o empreendedor enxergue a forma e a velocidade segundo a qual o empreendimento devolve e remunera os recursos emprestados, mas apenas o grau de remuneração auferido ao final do horizonte de análise (ROCHA LIMA JR., 2001). Portanto, em complemento à informação da taxa de retorno, ilustra-se a curva de formação da taxa de retorno. A curva de formação da $\underline{T I R}$ permite ao empreendedor reconhecer a forma segundo a qual a $\underline{\text { TIR }}$ é formada ao longo do ciclo de análise, à medida que o empreendedor recebe o fluxo $\left[\mathrm{R}_{\mathrm{k}}\right]$. A curva de formação da $\underline{T I R}$ nasce no instante em que o empreendimento devolve ao empreendedor os recursos nele investidos e passa, a partir de então, a remunerá-lo - payback pri e remata-se no último ano do horizonte de análise, quando atinge o valor da $\underline{T I R}$.

5. Duration - A duration oferece ao investidor uma referência acerca da velocidade segundo a qual o empreendimento o remunera. O indicador não carrega significado econômico ou financeiro, é uma medida matemática que, por assim sê-la, não se presta à avaliação de um investimento em particular, mas sim à comparação entre alternativas de investimento, naquilo que se relaciona à velocidade de remuneração dos recursos imobilizados em determinado investimento. A duration representa, matematicamente, o prazo médio ponderado, dentro do qual o empreendimento remunera o investidor à sua taxa interna de retorno. É uma medida de tempo que pode ser interpretada como o prazo de devolução do capital remunerado à TIR, em uma operação virtual equivalente, que tivesse apenas uma única posição de retorno no tempo. 
$d u r=\frac{\left(\sum_{k=1}^{n} \frac{R_{k}}{(1+T I R)^{k}} \times k\right)}{\sum_{k=1}^{n} \frac{R_{k}}{(1+T I R)^{k}}}$

Equação[5.8]

Na Equação[5.8]: [ $\mathrm{R}_{\mathrm{k}}$ ] é o retorno no ano k e [TIR] é a taxa interna de retorno.

A Tabela[5.9] traz os indicadores da qualidade na posição do cenário referencial.

\begin{tabular}{|c|c|c|c|}
\hline \multicolumn{4}{|c|}{$\begin{array}{l}\text { GERAÇÃO DE ENERGIA HIDRELÉTRICA - EMPREENDIM } \\
\text { INDICADORES DE QUALIDADE }\end{array}$} \\
\hline \multicolumn{4}{|c|}{ CENÁRIO REFERENCIAL } \\
\hline \multicolumn{4}{|l|}{ EMPREENDEDOR } \\
\hline TAXA INTERNA DE RETORNO & TIR & $12,5 \%$ & ao ano, efetiva acima do IPCA \\
\hline \multicolumn{4}{|l|}{ PAYBACK } \\
\hline Payback Primário & payback pri & 14 & no ano (contado do início do ciclo de análise) \\
\hline Payback ao Custo de Oportunidade & payback cop & 21 & no ano (contado do início do ciclo de análise) \\
\hline Payback à Taxa de Atratividade & payback tat & 31 & no ano (contado do início do ciclo de análise) \\
\hline DURATION & dur & 15 & anos \\
\hline \multicolumn{4}{|l|}{ NÍVEL DE EXPOSIÇÃO } \\
\hline Exposição Primária & EXP.max & 335.247 & $\mathrm{R} \$$ mil base \\
\hline Exposição ao Custo de Oportunidade & EXP max cop & 0 & $\mathrm{R} \$$ mil base \\
\hline \multicolumn{4}{|l|}{ INVESTIDOR - [TIEE-A1] } \\
\hline TAXA INTERNA DE RETORNO & TIR & $9,8 \%$ & ao ano, efetiva acima do IPCA \\
\hline \multicolumn{4}{|l|}{ PAYBACK } \\
\hline Payback Primário & payback pri & 6 & no ano (contado do início do ciclo de análise) \\
\hline Payback ao Custo de Oportunidade & payback cop & 6 & no ano (contado do início do ciclo de análise) \\
\hline DURATION & dur & 5 & anos \\
\hline \multicolumn{4}{|l|}{ NÍVEL DE EXPOSIÇÃO } \\
\hline Exposição Primária & EXP.max & 645.144 & $\mathrm{R} \$$ mil base \\
\hline Exposição ao Custo de Oportunidade & EXP max cop & 715.733 & $\mathrm{R} \$$ mil base \\
\hline \multicolumn{4}{|l|}{ INVESTIDOR - [TIEE-A2] } \\
\hline TAXA INTERNA DE RETORNO & TIR & $8,6 \%$ & ao ano, efetiva acima do IPCA \\
\hline \multicolumn{4}{|l|}{ PAYBACK } \\
\hline Payback Primário & payback pri & 14 & no ano (contado do início do ciclo de análise) \\
\hline Payback ao Custo de Oportunidade & payback cop & 18 & no ano (contado do início do ciclo de análise) \\
\hline DURATION & dur & 7 & anos \\
\hline \multicolumn{4}{|l|}{ NÍVEL DE EXPOSIÇÃO } \\
\hline Exposição Primária & EXP.max & 753.433 & $\mathrm{R} \$$ mil base \\
\hline Exposição ao Custo de Oportunidade & EXP max cop & 753.433 & $\mathrm{R} \$$ mil base \\
\hline
\end{tabular}

Tabela 5.9 - Indicadores da Qualidade no Cenário Referencial 
A Figura[5.3] traz as curvas de formação da $\underline{T I R}$ do empreendedor e dos investidores nos TIEE-A1 e TIEE-A2, bem como a $\underline{T I R}$ do BNDES no empreendimento, calculada sob o ponto de vista do financiador, onde o fluxo de investimento é composto pelos encaixes e o fluxo de retorno pelas parcelas de amortização e juros. A Figura[5.3] traz, ainda, a curva de formação da $\underline{T I R}$ que seria obtida pelo empreendedor, no cenário de referência, na situação em que $100 \%$ da equação de fundos fosse composta por recursos próprios, aportados pela via de conta de capital. A curva de formação da $\underline{T I R}$ do empreendedor, na condição de $85 \%$ de alavancagem $^{67}$ e na situação de equação de fundos formada $100 \%$ por recursos próprios, está representada, na Figura[5.3], nas curvas identificadas pela abreviatura $\underline{\text { TIRe. }}$.

A curva de formação da $\underline{T I R}$ permite reconhecer a forma segundo a qual o empreendimento remunera o empreendedor e investidores ao longo de seu ciclo operacional. O ponto em que cada curva se desprende do eixo da abscissa constitui o payback pri, analogamente a projeção, no eixo da abscissa, do ponto em que cada curva cruza a linha do custo de oportunidade - $\underline{c o p}$ corresponde ao payback cop e, a projeção, na abscissa, do ponto em que a curva do empreendedor cruza a linha da taxa de atratividade - tat, corresponde ao payback tat.

A taxa de retorno do empreendedor é calculada considerando o pagamento do imposto sobre a renda no ambiente da SPE, portanto, deve ser comparada ao custo de oportunidade líquido de IR, identificado pela curva COP na Figura [5.3]. Já as taxas de retorno dos TIEE-A1 e TIEEA2 são calculadas considerando o fluxo de rendimentos antes de pagamento de IR, portanto devem ser referenciadas considerando o custo de oportunidade antes do pagamento de IR.

A curva de formação da $\underline{T I R}$ permite ao empreendedor observar a rentabilidade que terá auferido, na hipótese que deixasse a posição de investimento antes do fim do prazo do contrato de concessão. Tal hipótese seria observada na ocasião da extinção da concessão, por exemplo por decisão de encampação dos bens e instalações vinculados por parte do Estado. Se simulamos a extinção da concessão no ano 20, por exemplo, o empreendimento já teria devolvido ao empreendedor os recursos nele imobilizados a uma taxa de retorno de $6,2 \%$, na hipótese em que não se considera nenhum valor adicional no fluxo de retorno do empreendedor, de natureza indenizatória, no ano da extinção.

\footnotetext{
${ }^{67}$ Calculado sobre o custo de obra e não sobre o total do custo de implantação.
} 


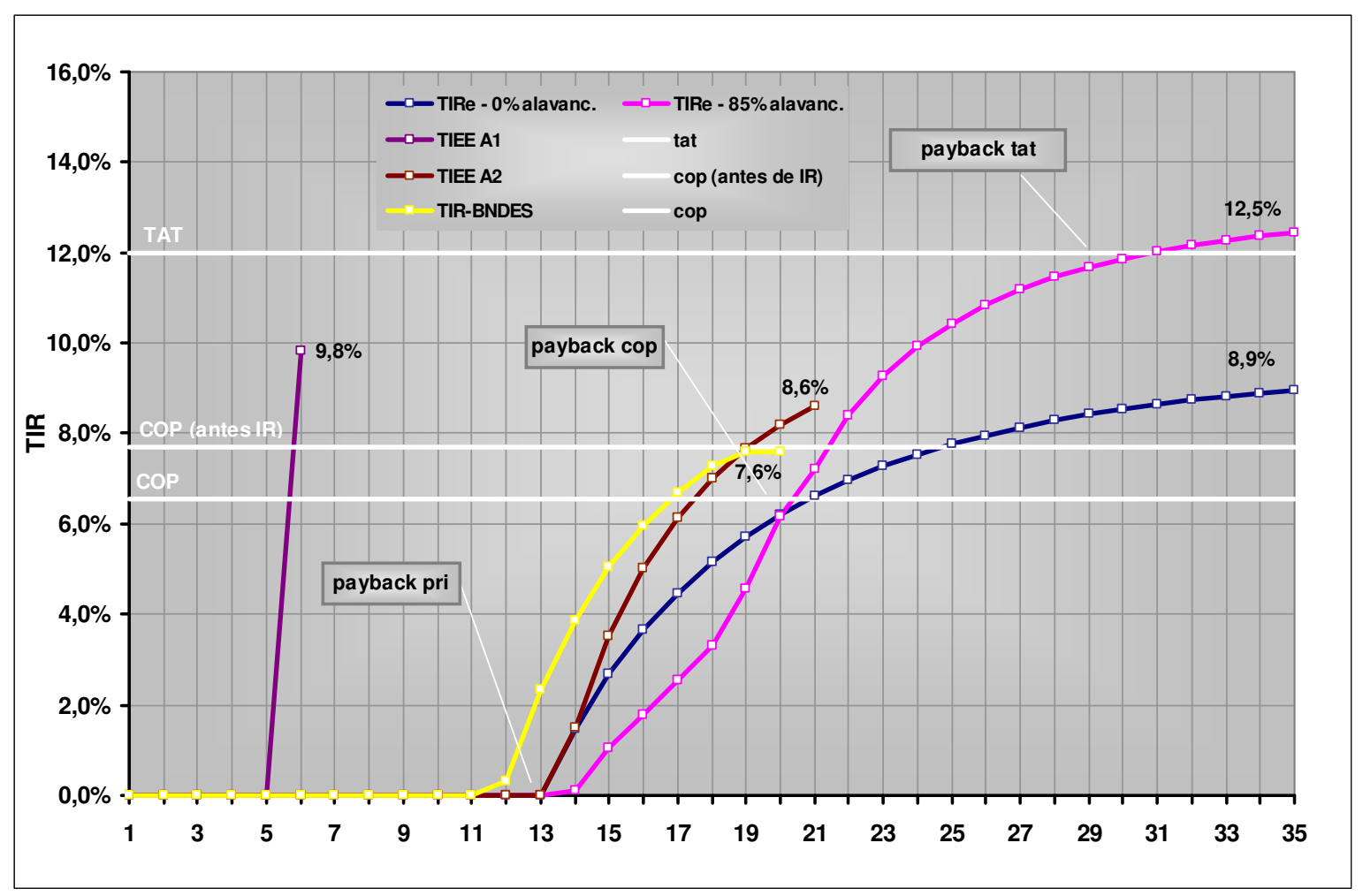

Figura 5.3 - Curva de Formação da $\underline{T I R}$

A Figura[5.4] traz a imagem do fluxo de Investimento $x$ Retorno acumulado do empreendedor e dos investidores nos TIEE-A1 e TIEE-A2. O ponto de mínimo de cada uma das curvas representa o ponto de máximo nível de exposição. Observa-se que o nível de exposição do empreendedor reduz-se sensivelmente com a alavancagem financeira do empreendimento. De outro lado, o fluxo Investimento $x$ Retorno acumulado, na condição alavancada, resulta inferior ao fluxo na condição em que $100 \%$ da equação de fundos é composta por recursos próprios, em virtude do pagamento de juros das dívidas com BNDES e investidores nas debêntures. 


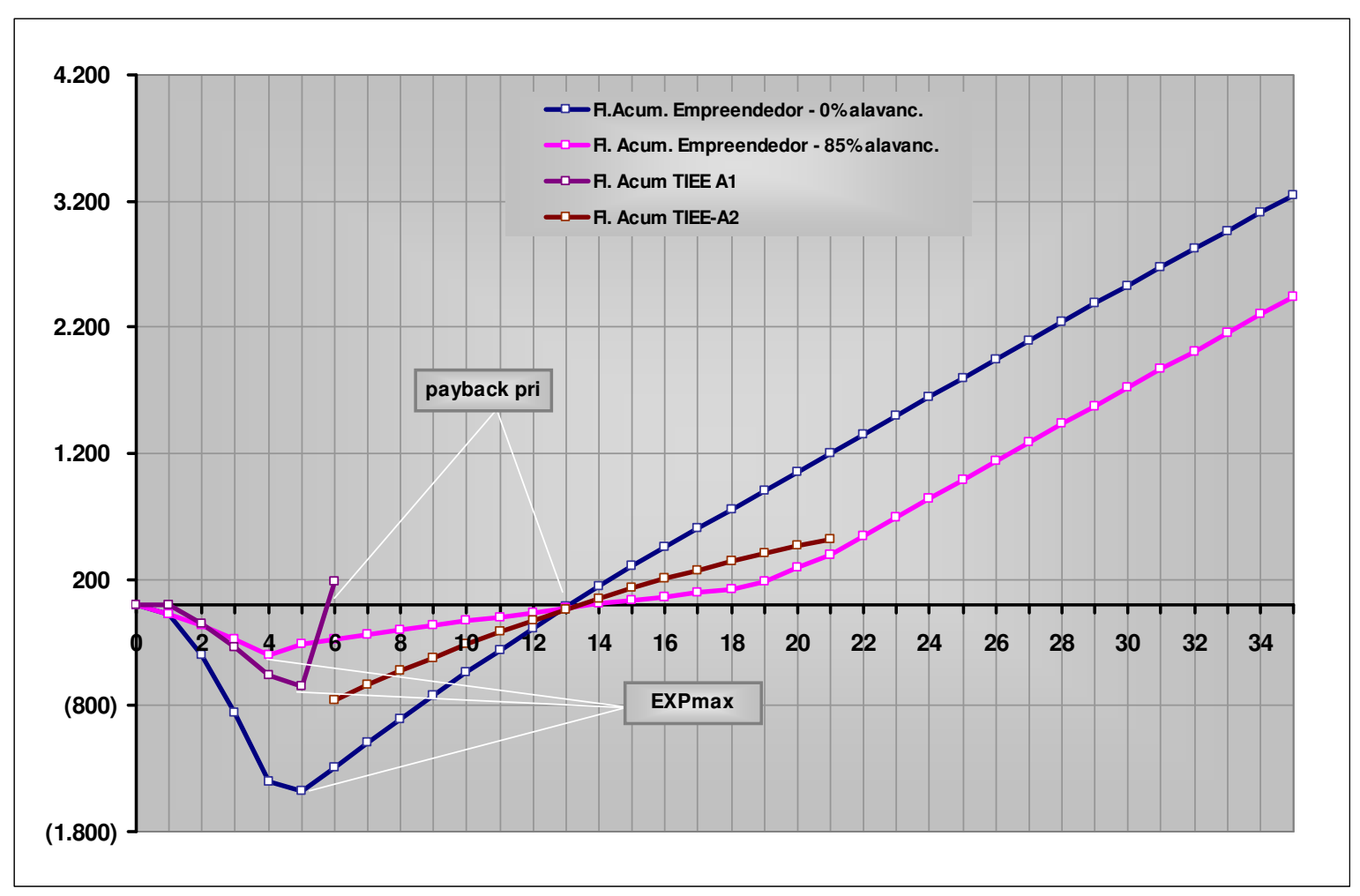

Figura 5.4 - Fluxo Investimento x Retorno Acumulado

A análise de sensibilidade e capacidade de suporte a ser desenvolvida na próxima seção deve enriquecer a avaliação dos resultados apresentados na tabela e nos gráficos acima. Entretanto, sobressai, da observação dos quadros, a $\underline{T I R}$ do empreendedor de $12,5 \%$ ao ano, efetiva acima do IPCA ${ }^{68}$, muito próxima do piso de atratividade - $12 \%$ ao ano, mesmo tendo arbitrado, no cenário referencial, preço da energia no ACR igual ao preço teto do produto hidro no leilão de out/2006 (valor aproximadamente 7,5\% superior à média de preços de venda dos empreendimentos novos nos leilões de dez/2005 e out/2006).

A $\underline{T I R}$, calculada considerando parâmetros médios dos aproveitamentos concedidos nos leilões de dez/2005 e out/2006 e preço próximo ao teto admitido para o produto hidro no leilão de out/06, mostra um desempenho econômico para o empreendedor, praticamente no patamar admitido como piso de atratividade para empreendimentos do setor.

Tal observação parece caminhar ao encontro da repercussão dos primeiros leilões de energia nova e das especulações acerca do padrão de rentabilidade reduzido para os investimentos nos

${ }^{68}$ Deste ponto em diante, toda referência ao indicador Taxa Interna de Retorno, quando não especificada em contrário, será feita considerando taxa anual, efetiva acima do IPCA. 
aproveitamentos licitados nas condições em que foram arrematados, principalmente no leilão de dez/2005, que teve participação sobressalente de empresas de capital público e pequeno interesse de empresas privadas.

O ANEXO A, que traz as características dos empreendimentos concedidos nos leilões de dez/2005 e out/2006, revela, a partir da verificação da relação [Custo de Implantação/Potência Instalada], que os empreendimentos arrematados no primeiro leilão têm atratividade reduzida relativamente aos empreendimentos concedidos no leilão de out/2006. Tal observação permite concluir que os resultados estariam ainda mais distantes da atratividade setorial se adotássemos, ao invés da média dos leilões de dez/05 e out/06, apenas a média dos parâmetros extraídos da amostra de empreendimentos do leilão de dez/05.

Em uma segunda vertente de análise, observa-se que a $\underline{T I R}$ calculada a partir do protótipo tem como base uma estrutura de funding que foge, propositadamente, à prática setorial, contribuindo para elevar a taxa de retorno do empreendimento, relativamente ao que se teria, utilizando a equação de fundos padrão de empreendimentos do setor.

Nesta análise, admitiu-se que, em substituição a uma parte dos recursos do BNDES, recursos foram captados via duas emissões públicas de debêntures, a primeira com prazo de 6 anos e, a segunda, com prazo de 15 anos, contados a partir do ano subseqüente ao término da primeira. Da composição da equação de fundos do empreendimento, observa-se o seguinte:

a. A taxa interna de retorno do empreendimento, medida considerando equação de fundos composta exclusivamente com recursos da conta de capital do empreendedor, é de 8,9\% ao ano, efetiva acima do IPCA - Figura[5.3]. Ao incorporarmos na análise, recursos do BNDES a um custo de 7,6\% e as emissões públicas resultantes nos TIEE-A1 e TIEE-A2, com custo de aproximadamente $9,8 \%$ e $8,6 \%$, a taxa de retorno dos recursos investidos pelo empreendedor salta de $8,9 \%$ para $12,5 \%$. Isto se explica, por três razões:

(i) a remuneração oferecida aos recursos do BNDES e aos TIEE-A2 é mais baixa do que a taxa interna de retorno do empreendimento, o que faz alavancar a taxa de retorno do empreendedor no empreendimento;

(ii) a substituição dos TIEE-A1 pelos TIEE-A2, ao final do período de construção, permite ao empreendedor, além de reduzir o custo da dívida, diferir o 
pagamento do seu principal em um prazo mais longo, o que propicia antecipação de seu fluxo de retorno e alavancagem da sua $\underline{T I R}$;

(iii)

o custo dos recursos de terceiros no empreendimento, leia-se BNDES e investidores nos TIEE-A1 e TIEE-A2, é deduzido da base de cálculo do imposto sobre a renda pago pela SPE, reduzindo o montante de imposto pago, em comparação à configuração onde a equação de fundos é composta exclusivamente por recursos da conta de capital do empreendedor.

b. A Figura [5.5] mostra a sensibilidade da $\underline{T I R}$ do empreendedor, quando se provocam variações no nível de alavancagem do empreendimento e alterações na composição da sua equação de fundos. A Figura [5.5] permite comparar as situações em que os recursos de terceiros no empreendimento são providos, em diferentes níveis, exclusivamente por BNDES, exclusivamente por debêntures de emissão públicas e, por um misto entre BNDES e debêntures.

A comparação entre as curvas [BNDES] e [TIEE-A1 + TIEE-A2], na Figura [5.5], mostra que a substituição de recursos do BNDES por recursos captados via emissão pública de debêntures, formatadas segundo parâmetros de mercado, tem pequeno impacto na $\underline{T I R}$ do empreendedor, mantendo-a no patamar da taxa que seria obtida em uma equação de fundos, cuja parcela de capital de terceiros, fosse composta exclusivamente por recursos do BNDES $^{69}$. Considerando nível de alavancagem de $80 \%$ sobre o custo de obra, percentual próximo do que se entende como limite de participação do BNDES, a curva [BNDES] mostra $\underline{T I R}$ do empreendedor de $11,8 \%$ e, a curva [TIEE-A1 + TIEE-A2], $\underline{T I R}$ de 12,6\%. Esta observação indica competitividade dos títulos lastreados em ativos, relativamente aos mecanismos tradicionais de financiamento de empreendimentos de infra-estrutura.

Observar que, na Figura[5.5], a alavancagem - fat.alav - está indicada como percentual do custo de obra e não do custo total de implantação, o qual inclui também as despesas préoperacionais. Na abscissa, a alavancagem máxima, igual a $85 \%$ do custo de obra, equivale a

${ }^{69}$ A observação é válida para as condições padrão das linhas de financiamento oferecidas pelo BNDES na data base da análise - dezembro de 2006. No início do ano de 2007, o governo federal lançou o Programa de Aceleração do Crescimento - PAC que, entre outras medidas, alterou as condições dos financiamentos do BNDES a empreendimentos hidrelétricos. As medidas lançadas no PAC implicaram em distensão dos prazos de carência e amortização dos contratos e sensíveis reduções no spread do BNDES nos financiamentos a empreendimentos do setor elétrico.

Se considerássemos as condições do financiamento do BNDES na condição pós PAC, certamente não se observaria, do ponto de vista do empreendedor, a condição de competitividade da captação de recursos pela via das debêntures frente aos recursos captados via BNDES, tal qual enunciou-se. 
76,5\% do custo de implantação. A condição de máxima alavancagem, na curva em que a conta de recursos de terceiros é composta exclusivamente por BNDES, de $80 \%$ sobre o custo de obra, equivale a $72 \%$ do custo de implantação.

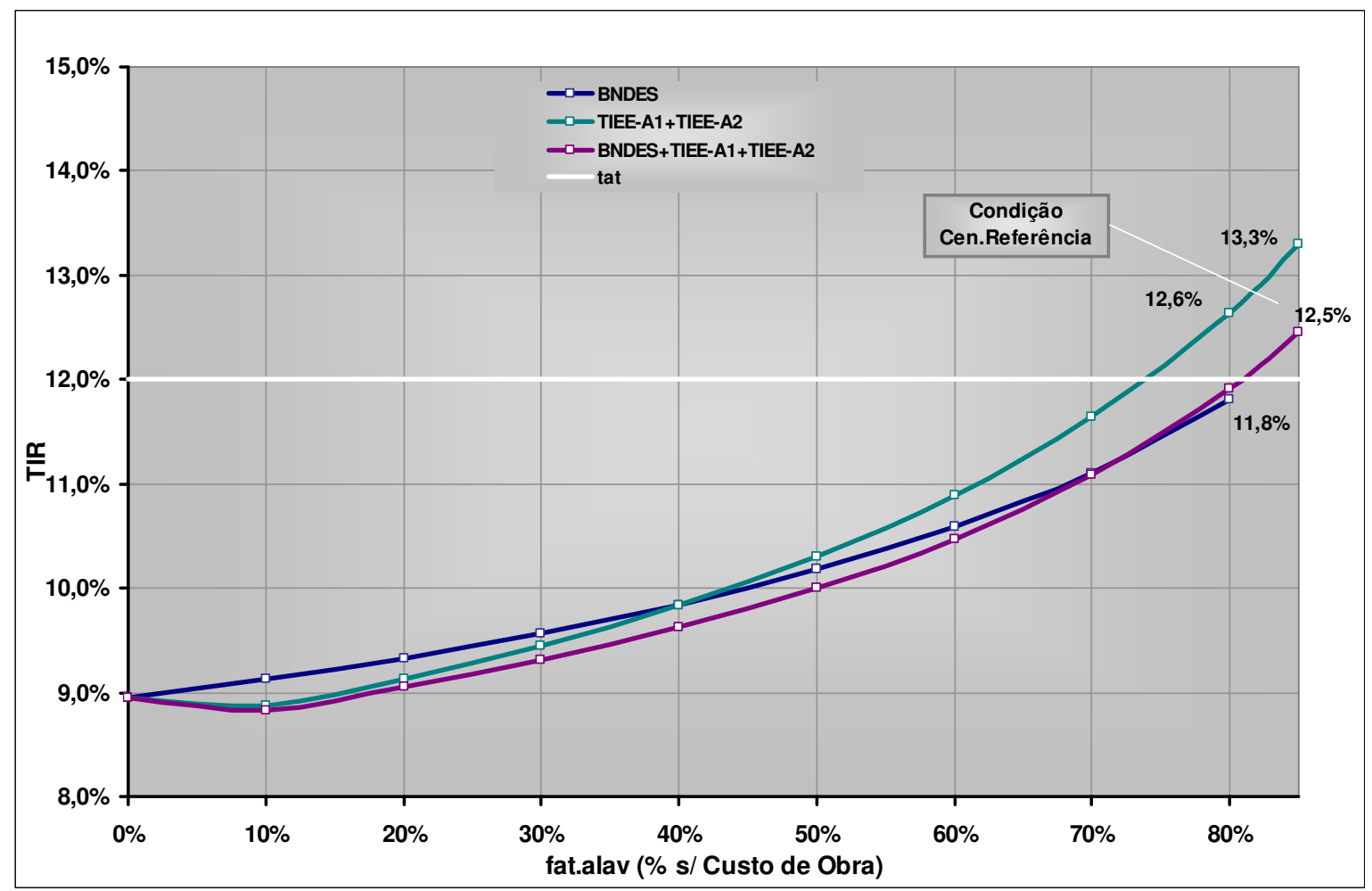

Figura 5.5 - TIR x Alavancagem, alternando a composição da equação de fundos 


\subsection{ANÁLISE DE RISCOS}

A rotina de análise de risco está composta de duas etapas: (i) a análise de risco que leva em conta efeitos discretos, aqui tratada, de forma simplificada, como análise de risco de efeitos discretos e (ii) a análise que leva em conta efeitos cruzados, da mesma forma, por simplificação, aqui tratada como análise de risco de efeitos cruzados.

O objetivo da análise de risco de efeitos discretos é reconhecer desvios dos indicadores da qualidade do investimento quando se aplicam distensões, isoladas, nas variáveis do sistema empreendimento ou de seu ambiente, relativamente à posição arbitrada no cenário referencial. De outro lado, na análise de risco de efeitos cruzados, o objetivo é reconhecer o efeito, nos indicadores da qualidade do investimento, de distúrbios combinados nas variáveis do sistema empreendimento e do seu ambiente.

Em toda a rotina de análise, quando pequenas deformações de cenário implicam em grandes desvios de comportamento, diz-se que os indicadores da qualidade têm alta sensibilidade à variável, ou conjunto de variáveis estudadas. Do contrário, quando grandes deformações provocam pequenos desvios de comportamento, diz-se que os indicadores têm baixa sensibilidade. Adicionalmente, buscar-se-á calibrar intervalos de deformação, para variáveis contidas no cenário referencial, que permitam identificar os níveis de distúrbios que levam os indicadores da qualidade aos limites de comportamento ${ }^{70}$, posição esta, que se definirá como capacidade de suporte do empreendimento para desvios.

A deformação de cenário pode ser provocada a partir da aplicação de um fator de distúrbio, permanente ou de comportamento disperso, sobre as variáveis estudadas.

Quando se aplica fator de distúrbio permanente, assumem-se distensões pontuais, definidas de forma determinística, sobre a variável estudada, ao longo de todo o ciclo de análise. Quando se usa fator de distúrbio de comportamento disperso, admite-se flutuação aleatória da variável estudada, dentro de fronteiras arbitradas. Na análise dispersa, os resultados são extraídos a partir do tratamento estatístico de uma amostra dos indicadores da qualidade, produzida em laboratório, a partir da simulação de um conjunto de cenários gerados randomicamente.

\footnotetext{
${ }^{70}$ Referem-se aos parâmetros de rentabilidade tat e cop.
} 
No decorrer da análise de risco de efeitos discretos, a utilização de variações permanentes ou dispersa respeitará o padrão de flutuação da variável estudada. Na análise de risco de efeitos cruzados, entretanto, para que não sejam potencializados os efeitos de distúrbios combinados, a flutuação das variáveis será sempre dispersa e os resultados sempre apoiados em cenários de geração randômica. Assim, as informações resultantes da análise de risco de efeitos cruzados oferecerão, ao empreendedor, uma visão abrangente do desempenho econômico do empreendimento, ao simular um largo espectro de cenários. Permitirão, ao empreendedor, acessar uma imagem, que se crê mais fiel, do seu binômio rentabilidade $x$ risco, porque é produzida a partir de múltiplos cenários, construídos cada um com variáveis parametrizadas de maneira aleatória, sem viés ou interferência do planejador. A ação do planejador está apenas na arbitragem das fronteiras de comportamento, mas não na combinação do estado de cada variável para formatação de um particular cenário.

\subsubsection{Análise de Risco de Efeitos Discretos}

$\mathrm{Na}$ análise de riscos de efeitos discretos serão estudados efeitos sobre os indicadores da qualidade de:

- Desvios nos Custos de Implantação

- Atraso na Entrada em Operação Comercial

- Desvios nos Custos de Operação e Manutenção

- Flutuação da Quantidade de Energia Disponível

- Variação de Preço da Energia

- Variação do percentual de energia destinado à comercialização no ACL

- Flutuação dos índices de inflação e juros - variação do IPCA, ISC, ISEE e TJLP

Os limites de variação para análise de risco de efeitos discretos estão indicados na Tabela[5.10]. 


\begin{tabular}{|c|c|c|c|c|c|}
\hline \multicolumn{6}{|c|}{ GERAÇÃO DE ENERGIA HIDRELÉTRICA - EMPREENDIMENTO PROTÓTIPO } \\
\hline \multicolumn{6}{|c|}{ ANÁLISE DE RISCO DE EFEITOS DISCRETOS } \\
\hline \multicolumn{6}{|c|}{ FRONTEIRAS DE COMPORTAMENTO } \\
\hline VARIAVEIS ANALISADAS & & $\begin{array}{l}\text { FATOR DE } \\
\text { DISTÚRBIO }\end{array}$ & $\begin{array}{c}\text { CENÁRIO } \\
\text { REFERENCIAL }\end{array}$ & $\begin{array}{l}\text { FRONTEIRAS } \\
\text { INFERIOR }\end{array}$ & $\begin{array}{l}\text { ARBITRADAS } \\
\text { SUPERIOR }\end{array}$ \\
\hline \multicolumn{6}{|l|}{ VARIÁVEIS MACROECONÔMICAS } \\
\hline IPCA & $\%$ ao ano & fat.econ & $3,5 \%$ & $3,0 \%$ & $5,5 \%$ \\
\hline \multicolumn{6}{|l|}{ descolamento IPCA } \\
\hline Taxa de Juros de Longo Prazo - TJLP & ao ano, acima do IPCA & fat.econ & $3,5 \%$ & $2,5 \%$ & $5,5 \%$ \\
\hline Índice de Inflação de Custos de Construção - ISC & ao ano, acima do IPCA & fat.econ & $0,0 \%$ & $-0,5 \%$ & $2,0 \%$ \\
\hline Índice de Inflação de Custos de Operação de Hidrelétrica - ISE & ao ano, acima do IPCA & fat.econ & $0,0 \%$ & $-0,5 \%$ & $2,0 \%$ \\
\hline \multicolumn{6}{|l|}{ ENERGIA } \\
\hline Energia Gerada pelo Sistema Hídrico & & fat.sist & 1,00 & 0,90 & 1,00 \\
\hline Energia Disponível para Atendimento de Obrigações Contratuais & GWh & & 2.569 & 2.312 & 2.569 \\
\hline Preço ACL & $\mathrm{R} \$ / \mathrm{MWh}$ & fat.taracl & 105,0 & 62,0 & 170,0 \\
\hline Preço PLD & $\mathrm{R} \$ / \mathrm{MWh}$ & fat.tarpld & 62,0 & 62,0 & 300,0 \\
\hline \multicolumn{6}{|l|}{ CONTAS DE IMPLANTAÇÃO } \\
\hline Custo Base de Implantação & $\mathrm{R} \$ \mathrm{mil} / \mathrm{MW}$ inst. & fat.impl & 3.224 & 3.224 & 4.191 \\
\hline Atraso na Entrega das Obras & meses & fat.atraso & 0 & 2 & 7 \\
\hline \multicolumn{6}{|l|}{ CONTAS DE OPERAÇÃO } \\
\hline Custo Base de Operação e Manutenção & $\mathrm{R} \$ / \mathrm{MWh}$ & fat.coper & 3,61 & 3,3 & 4,5 \\
\hline
\end{tabular}

Tabela 5.10 - Fronteiras de Comportamento para Análise de Risco de Efeitos Discretos

\section{- Desvios nos Custos de Implantação}

Para estudar os desvios nos custos de implantação, introduziu-se na análise um fator fat.impl sobre o Custo Unitário de Implantação. No cenário referencial, o Custo Unitário de Implantação é de 3.224 [R $\$$ base mil/MW]. A Figura[5.6] mostra o comportamento do indicador $\underline{T I R}$ do empreendedor para incrementos de até $30 \%$ no orçamento base de implantação. Na Figura[5.6], fat.impl igual a 1, corresponde ao Custo Unitário de Implantação de 3.224 [R \$ base mil /MW] e fat.impl igual a 1,3, a um Custo Unitário de Implantação de 4.191 [R $\$$ base mil/MW]. 


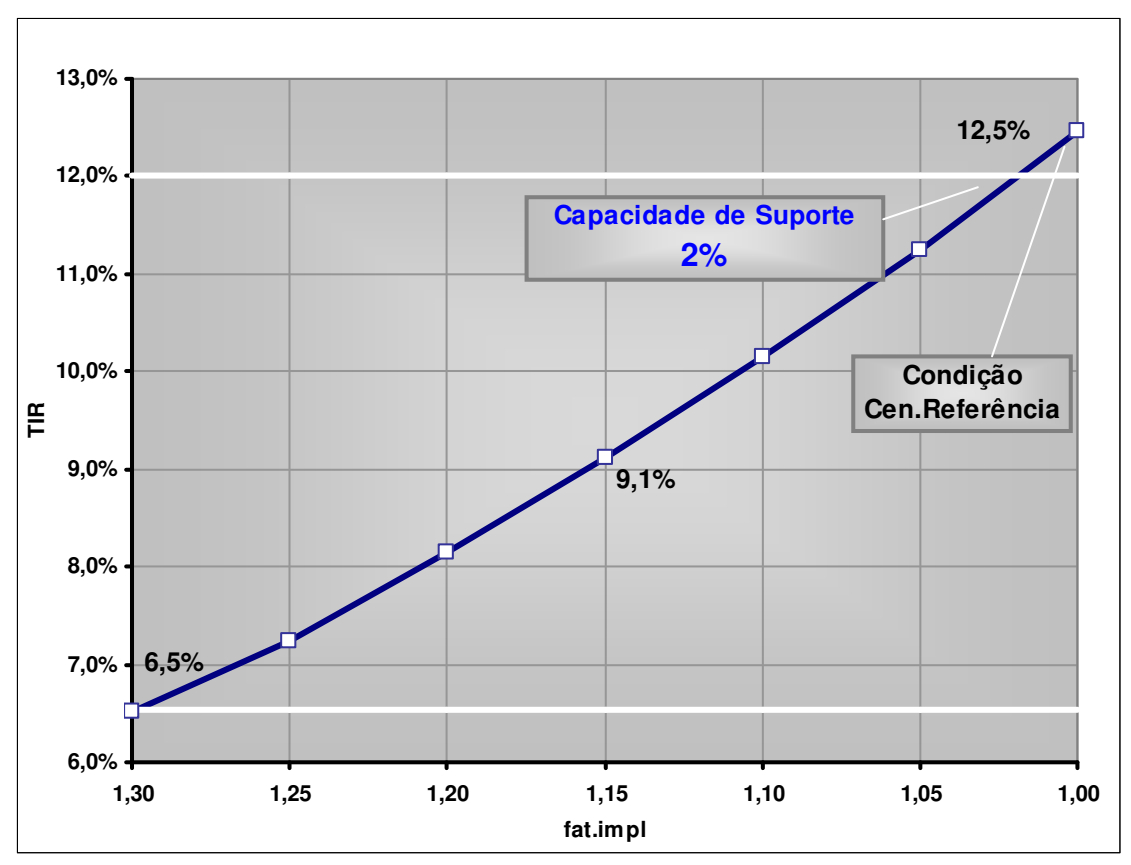

Figura 5.6 - Desvios no Custo de Implantação

A Figura[5.6] mostra alta sensibilidade do indicador $\underline{T I R}$ às variações no custo de implantação. No cenário referencial, a $\underline{T I R}$ é pouco superior ao patamar arbitrado para a Taxa de Atratividade. Pela alta sensibilidade do indicador $\underline{T I R}$ e por já situar-se próximo da taxa de atratividade no cenário referencial, o empreendimento revela baixa capacidade de suporte para desvios nos custos de implantação. Um incremento isolado nos custos de implantação de $2 \%$ levaria a $\underline{T I R}$ do empreendedor para os níveis da taxa de atratividade, caso todas as outras variáveis fossem mantidas na posição do cenário referencial. De forma análoga, o gráfico permite inferir que a distensão que leva a $\underline{T I R}$ do empreendedor para os níveis do custo de oportunidade é de $30 \%$.

Os indicadores [Custo de Implantação/Potência Instalada] e [Garantia Física/Potência Instalada] são, em uma análise singela, os fatores que definem o grau de atratividade do investimento em um empreendimento hidrelétrico. No leilão de dez/2005, o índice médio [Custo de Implantação/Potência Instalada] foi de 3.691 [R\$ base mil/MW]; no leilão de out/2006, o índice médio dos empreendimentos concedidos foi de 2.619 [R $\$$ base mil/MW]. Tal fator explica, ao menos em parte, o maior interesse do investidor privado e o menor preço da energia dos empreendimentos concedidos no segundo leilão do que aqueles concedidos no primeiro, arrematados na maioria por empresas do setor público, por preços próximos do 
limite imposto à época do leilão de 116 [R $\$ / M W h]$ - aproximadamente 119,5 [R\$ base/MWh].

A Figura[5.7] traz, na coordenada, a $\underline{T I R}$ do empreendedor, na abscissa, o Custo de Implantação Unitário [Custo de Implantação/ Potência Instalada] e, no quadrante, distintos patamares de preço de energia no ACR.

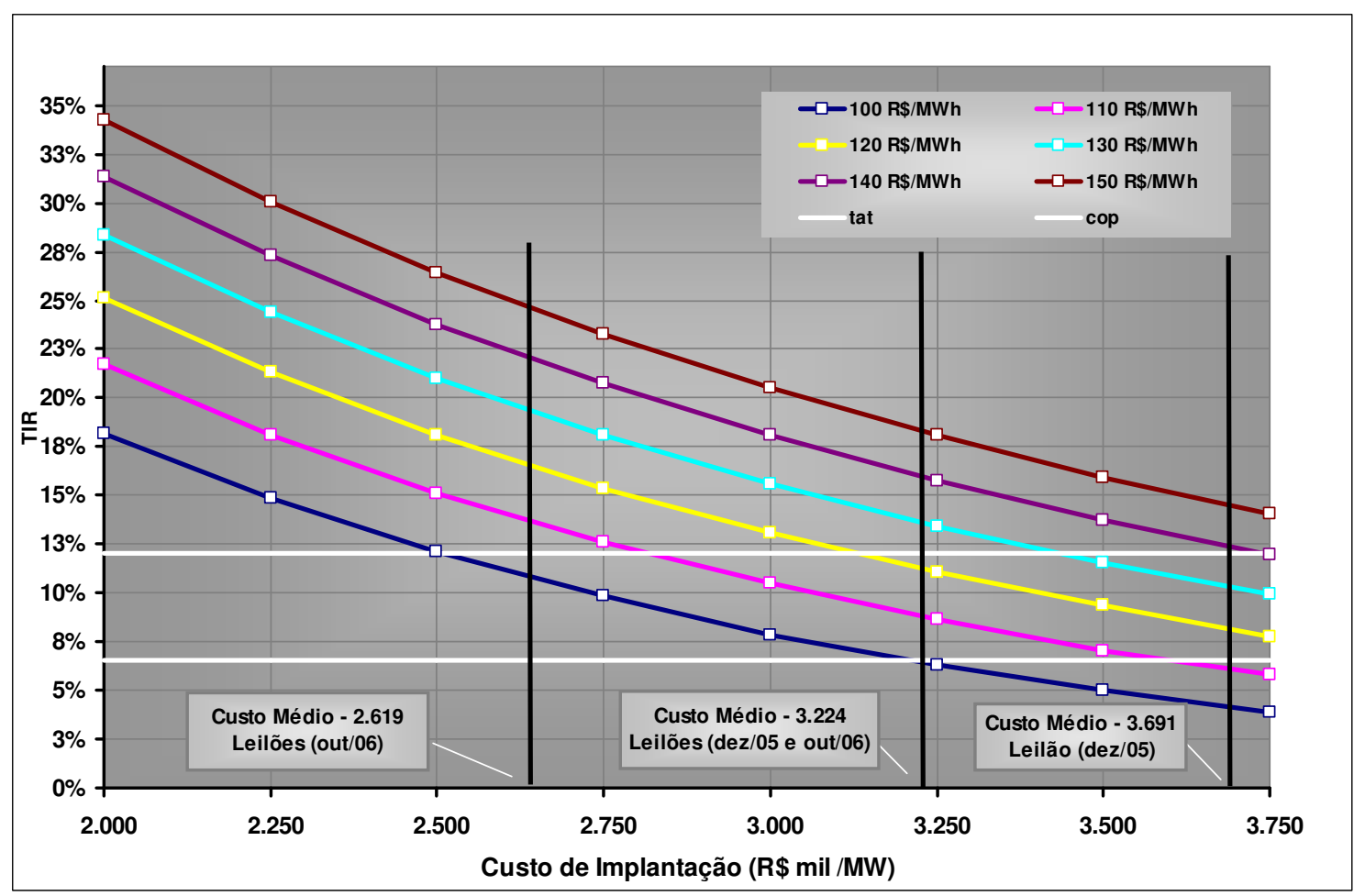

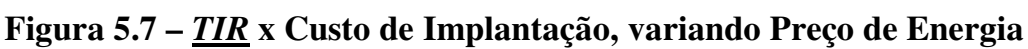

A Figura[5.7] permite inferir, em uma análise singela, onde apenas variam preço da energia no ACR e Custo de Implantação Unitário, permanecendo todas as outras variáveis no estado em que foram arbitradas no cenário referencial que: (i) o preço que levaria a $\underline{T I R}$ do empreendimento protótipo ao patamar da taxa de atratividade setorial, seria aproximadamente 140 [R \$ base/MWh], caso seu Custo Unitário de Implantação [Custo de Implantação/Potência Instalada] fosse igual à média ponderada dos custos dos empreendimentos concedidos no leilão de dez/2005; (ii) o preço que levaria a $\underline{T I R}$ do empreendimento protótipo ao patamar da taxa de atratividade setorial, seria aproximadamente 105 [R $\$$ base/MWh], caso seu Custo Unitário de Implantação fosse igual à média ponderada dos custos dos empreendimentos concedidos no leilão de out/2006. 
Sob outro foco de análise, ao tomar-se como base o preço médio da energia com o qual foram arrematados os empreendimentos em dez/05, valor compreendido entre 115 e 120 [R $\$$ base/MWh], considerando demais condições similares à arbitrada para o protótipo, verifica-se $\underline{T I R}$ do empreendedor próxima a $8 \%$ ao ano. Análise semelhante para os empreendimentos concedidos em out/06, por preço aproximado de 113 [R $\$$ base/ MWh], revela $\underline{T I R}$ próxima de $15 \%$ ao ano. Esta observação parece corroborar a insatisfação do mercado com o patamar de preço praticado no leilão de dez/05 e a maior participação das empresas públicas nas novas concessões outorgadas neste evento.

De fato, a taxa de atratividade das empresas públicas de geração parece estar situada em patamar sensivelmente inferior à taxa de atratividade dos empreendedores do setor privado. MERRILL LYNCH (2007), em relatório em que apresenta comportamento do setor elétrico em países emergentes, aponta o critério de validação de investimentos de empresas públicas, como fator de viés negativo ao investimento privado, no âmbito da política energética brasileira $^{71}$ :

Um fator complicador é a Eletrobrás, maior produtor de energia no Brasil, empresa controlada pelo governo federal. Há um conflito entre o preço, ou a faixa de preço, que pode oferecer retornos aceitáveis para investidores privados e preços que possam oferecer retornos aceitáveis para a Eletrobrás. Adicionalmente, esforços do governo para intensificar investimentos da Eletrobrás podem também limitar a presença privada em novos investimentos no setor.

Ao comentar o cenário de preços para os próximos leilões de energia nova, MERRILL LYNCH (2007) destaca o seguinte:

Acreditamos que o Brasil necessite incrementar sua capacidade instalada em 5\% ao ano para um cenário de crescimento do PIB de 4\% ao ano...isto demandaria montante aproximado de investimentos de US\$ 35 bilhões para o decênio 2006-2015. Ainda que a Eletrobrás, maior produtor de energia do Brasil, realize significativos investimentos em geração, enxergamos a necessidade do setor privado prover também nova capacidade. Para atrair o investimento privado, cremos que o governo terá que aumentar os limites de preço nos leilões para contratação de energia.

${ }^{71}$ Tradução nossa (original em inglês). 
- Atrasos na Entrada em Operação Comercial

Para estudar o impacto de atrasos, somou-se um fator fat.atraso sobre o cronograma de entrada em operação comercial das unidades de geração. A simulação do atraso, da maneira como lançada na análise apoiada no protótipo, reflete situação de postergação da operação das máquinas, por não obtenção de licença ambiental de operação. O fat.atraso oscila entre 2 e 7 meses. A Figura[5.8] traz os efeitos do atraso no indicador $\underline{T I R}$ do empreendedor.

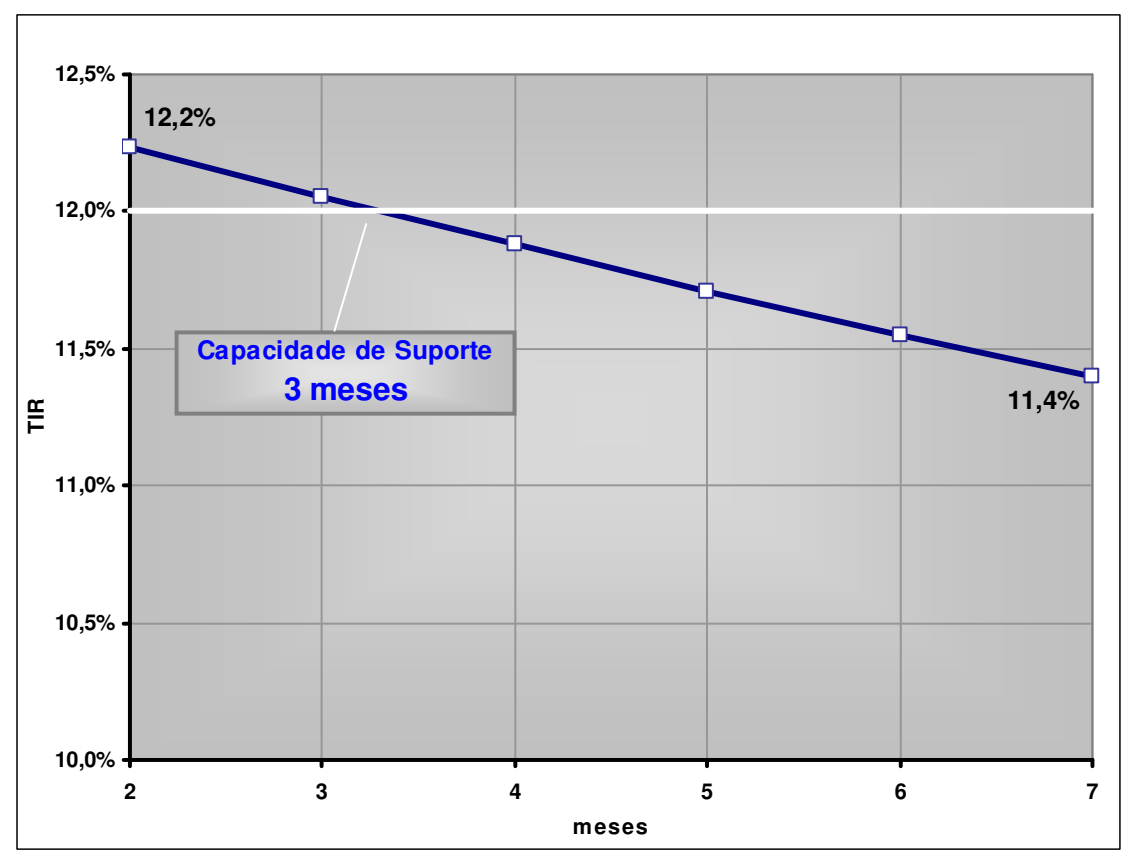

Figura 5.8 - Atraso na Entrada em Operação Comercial

A Figura[5.8] mostra que o empreendimento suporta atrasos de aproximadamente 3 meses. Atrasos de aproximadamente 3 meses na entrada em operação comercial das unidades geradoras, levam a $\underline{T I R}$ do empreendedor ao patamar da taxa de atratividade.

A introdução do fat.atraso faz com que o empreendedor não tenha a usina operando, à plena carga, no período em que tem início a vigência dos CCEAR's. A quantidade insuficiente de energia disponível obriga o empreendedor a recorrer ao mercado de curto prazo, para adquirir a energia restante para o cumprimento de seus contratos. 
Portanto, vê-se que os efeitos do atraso na entrada em operação comercial estão intimamente vinculados ao comportamento do PLD. A conjunção dos distúrbios no prazo para entrada em operação e no PLD será considerada quando da análise de risco cruzada.

- Desvios nos Custos de Operação e Manutenção

Para estudar os desvios nos custos de operação e manutenção introduziu-se na análise um fator fat.coper sobre o Custo Unitário de Operação e Manutenção. No cenário referencial, o Custo Unitário de Operação e Manutenção é de 3,61 [R \$ base/MWh]. A Figura[5.9] mostra o comportamento do indicador $\underline{\text { TIR }}$ do empreendedor para incrementos de até $220 \%$ no Custo Unitário de Operação e Manutenção. Na Figura[5.9], fat.coper igual a 1 corresponde ao custo de operação e manutenção de 3,61 [R $\$$ base/MWh] e fat.coper igual a 2,2, a um custo de operação e manutenção de 7,94 [R \$ base/MWh].

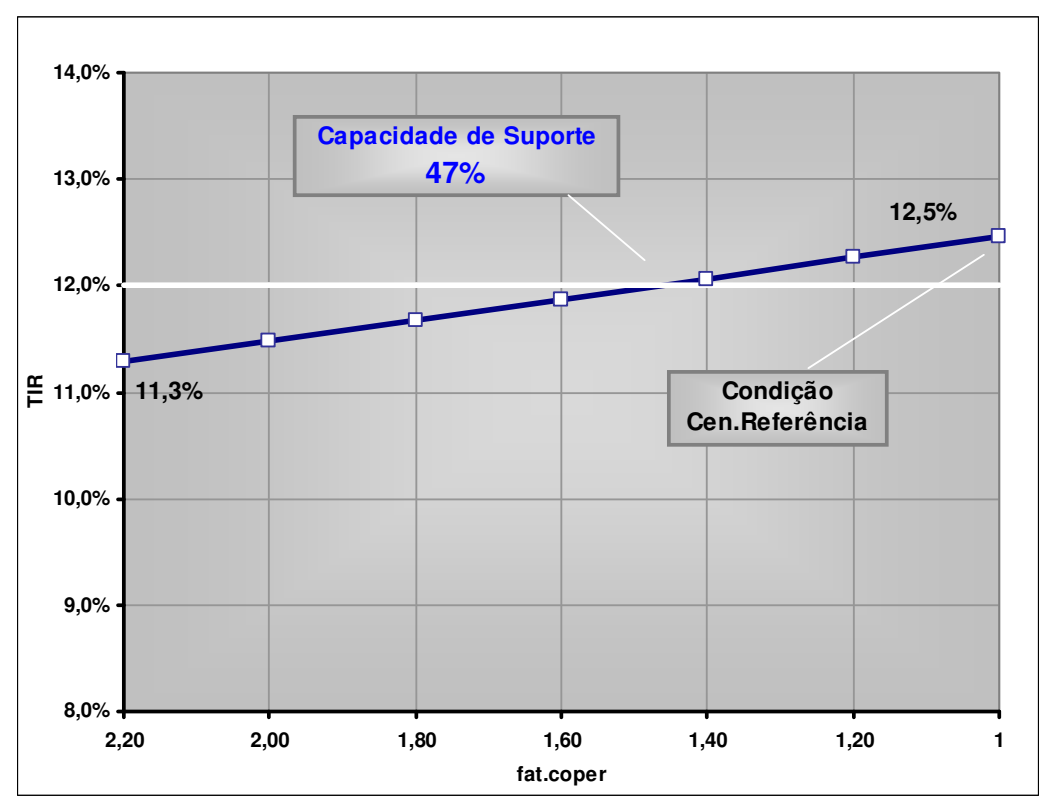

Figura 5.9 - Desvios no Custo de Operação e Manutenção

Na Figura[5.9], um incremento de $220 \%$ no Custo Unitário de Operação e Manutenção provoca uma redução da $\underline{T I R}$ do empreendedor de, $12,5 \%$, no cenário referencial, para 11,3\%. O empreendimento apresenta alta capacidade de suporte para desvios dos custos de operação e manutenção. Desvios isolados de aproximadamente $47 \%$, em relação à posição no cenário 
referencial, são necessários para levar a $\underline{T I R}$ do empreendedor para o patamar da taxa de atratividade.

A baixa sensibilidade aos desvios nos custos operacionais é uma característica típica de empreendimentos intensivos em capital, de longo prazo de maturação, como empreendimentos que envolvem a implantação e operação de infra-estrutura.

\section{- Flutuação da Quantidade de Energia Disponível}

Para analisar os efeitos de quebras na quantidade de energia, optou-se pelo estudo considerando redução permanente e, em uma segunda análise, como função da aleatoriedade da variável, flutuação dispersa da energia disponível.

No modelo regulatório vigente, o gerador hídrico participa do MRE. Segundo este mecanismo, todo o gerador hídrico entrega a energia por ele gerada ao sistema e retoma, de forma proporcional à participação da sua usina na energia total assegurada do sistema hídrico, parcela correspondente da energia efetivamente gerada pelo sistema. As transferências de energia entre geradores hídricos são feitas ao valor de 7,25 [R \$ base/MWh], valor assumido como suficiente para ressarcir o agente gerador superavitário no MRE, dos custos de operação e manutenção e COFURH. Como o Custo Unitário de Operação e Manutenção, no cenário referencial, foi arbitrado tendo como referência o valor da energia no MRE, é indiferente para o empreendedor, no caso da usina protótipo, gerar a energia para seus contratos, ou adquiri-la de outros geradores via MRE. Assim, não teria sentido estudar variações na energia efetivamente gerada pela usina protótipo, mas sim variações na quantidade de energia a ela atribuída após as transferências no MRE. A esta energia deu-se o nome, nesta dissertação, de Energia Disponível.

Para estudar quebras na quantidade de energia disponível, introduziu-se na análise um fator fat.ger sobre a energia disponível da usina. No cenário referencial, a quantidade de energia disponível equivale a $100 \%$ da energia assegurada. A Figura[5.10] mostra o comportamento do indicador $\underline{\text { TIR }}$ do empreendedor para decrementos de até $30 \%$ na energia disponível. O gerador hídrico contratado na modalidade quantidade de energia recebe sempre pelo montante de energia fixado em contrato. Quando a quantidade de energia disponível é maior ou menor 
que a energia dos seus contratos, as diferenças são liquidadas no mercado de curto prazo, ao PLD.

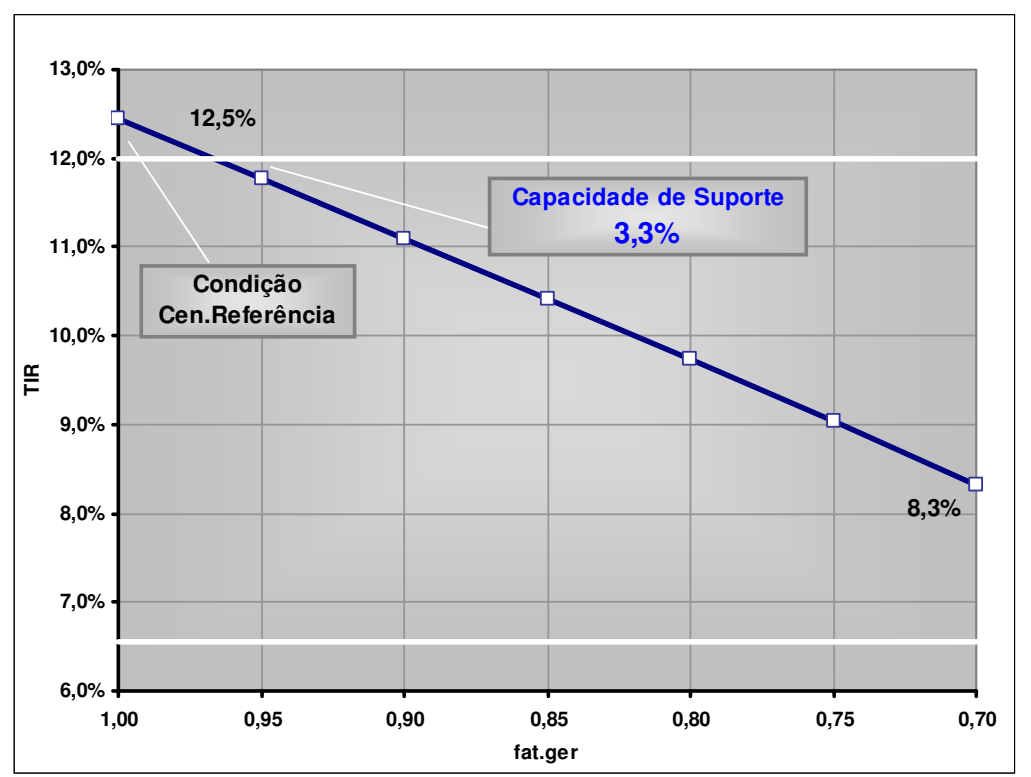

Figura 5.10 - Quebra na Quantidade de Energia Disponível

A Figura[5.10] mostra alta sensibilidade do empreendimento para distúrbios na energia disponível. O empreendimento suporta um decremento, permanente, ao longo de todo o ciclo de análise, de até 3,3\% na energia disponível. Redução mais intensa na quantidade de energia levaria a $\underline{T I R}$ do empreendedor a um patamar inferior ao da taxa de atratividade setorial.

Contudo, a aplicação de um fator de quebra de forma discreta não reflete o padrão de flutuação da energia disponível. Quando se assume um decremento da quantidade de energia disponível, pela aplicação de um fator de quebra permanente, estende-se a redução uniformemente a todo horizonte de análise. Em função da aleatoriedade da variável, a forma preferível para avaliar os impactos nos indicadores da qualidade, de variações na quantidade de energia disponível, seria admitir flutuação dispersa entre fronteiras, do valor da energia, dentro de cada ano do horizonte de análise.

No Figura[5.11], arbitrou-se comportamento aleatório da quantidade de energia disponível, entre $90 \%$ e $100 \%$, fronteiras, respectivamente, conservadora e agressiva, definidas a luz da relação anual [Energia Gerada/ Energia Assegurada], observada entre os anos de 2000 e 2005 para usinas do sistema hídrico no Brasil. 
A Tabela[5.11] traz os valores utilizados como parâmetros para relação [Energia Gerada/Energia Assegurada] pelo sistema hídrico e a Figura[5.11] ilustra os efeitos nos indicadores da qualidade, quando fazemos flutuar a energia disponível dentro da faixa arbitrada. Os resultados na Figura[5.11] foram extraídos a partir do tratamento estatístico de uma amostra do indicador $\underline{T I R}$, produzida a partir da simulação de cenários de geração randômica. A Figura[5.11] traz o intervalo de confiança no qual poderá situar-se a média do indicador $\underline{T I R}$ do empreendedor, para um padrão de confiabilidade de $90 \%$.

\begin{tabular}{|c|c|c|c|}
\hline \multicolumn{4}{|c|}{ ENERGIA GERADA PELOS SISTEMA HÍDRICO } \\
\hline \multicolumn{4}{|c|}{ DADOS MÉDIOS NO ANO - 2000 A 2005} \\
\hline & GERAÇÃO MRE & ENERGIA ASSEGURADA & \\
\hline ANO & $\begin{array}{c}\text { [1] } \\
\text { GWh }\end{array}$ & $\begin{array}{c}\text { [2] } \\
\text { GWh }\end{array}$ & [1] / [2] \\
\hline 2.005 & 29.858 & 29.598 & $101 \%$ \\
\hline 2.004 & 28.279 & 29.697 & $95 \%$ \\
\hline 2.003 & 27.283 & 29.493 & $93 \%$ \\
\hline 2.002 & 26.920 & 28.783 & $94 \%$ \\
\hline 2.001 & 24.199 & 28.049 & $86 \%$ \\
\hline 2.000 & 27.510 & 27.270 & $101 \%$ \\
\hline
\end{tabular}

Tabela 5.11 - Relação [Energia Gerada / Energia Assegurada] do Sistema Hídrico Fonte: Câmara de Comercialização de Energia Elétrica - CCEE (dezembro/2006)

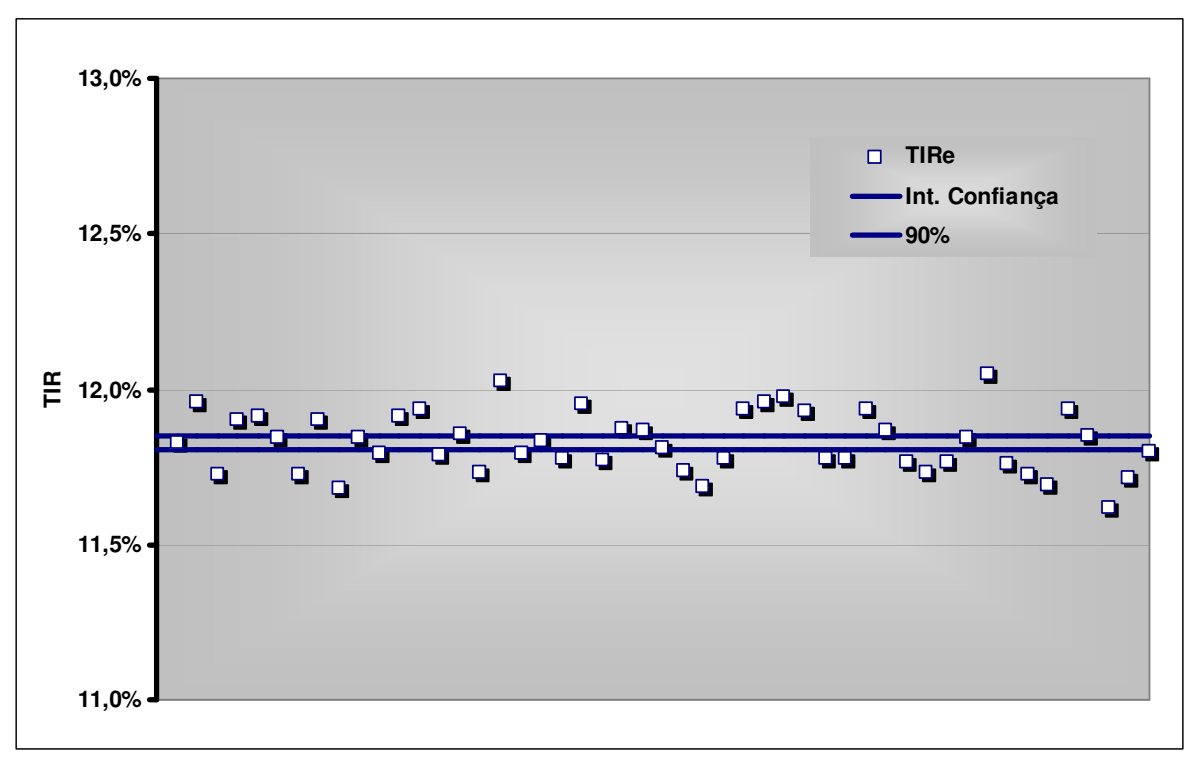

Figura 5.11 - Flutuação Dispersa da Energia Disponível 
Considerando a variação dispersa da quantidade de energia ao longo do horizonte de análise, o que se observa é uma pequena sensibilidade do empreendimento à variação na quantidade de energia, quando o estudo é feito de forma isolada, mantendo todas as outras variáveis na posição do cenário referencial. A variação dispersa da quantidade de energia disponível leva a $\underline{T I R}$ do empreendedor de $12,5 \%$ no cenário de referência para o intervalo de $11,8 \%$ a 11,9\%, para um padrão de confiabilidade da informação de $90 \%$.

Apesar de analisada de forma isolada, a intensidade do impacto nos indicadores da qualidade de flutuações da energia disponível está intimamente vinculada ao comportamento do PLD. A flutuação combinada destas duas variáveis será estudada quando da análise de risco de efeitos cruzados.

- Variações de preço no ACR

Para estudar o efeito de variações nos preços de energia no ACR, introduziu-se na análise um fator fat.preçoACR sobre as tarifas no ACR.

No cenário referencial, a tarifa, no ACR, é de 125 [R\$ base/MWh]. A Figura[5.12] mostra o comportamento do indicador $\underline{T I R}$ do empreendedor para flutuações do preço da energia entre $85 \%$ e $115 \%$ da posição no cenário referencial.

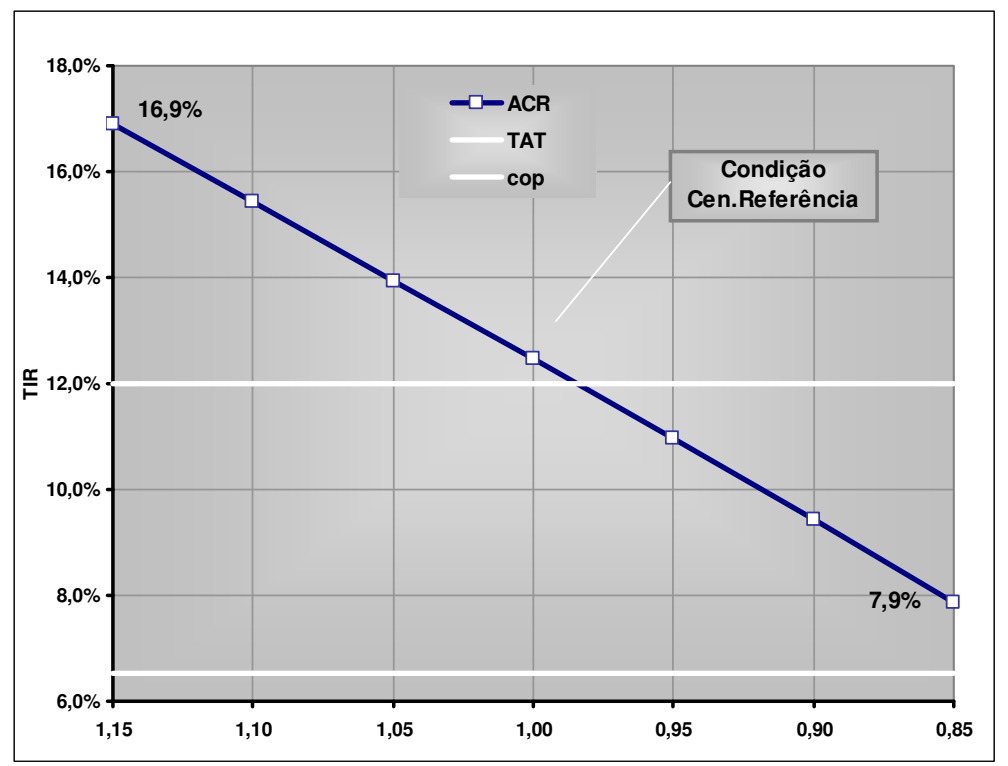

Figura 5.12 - Variações de Preço no ACR 
O gráfico mostra que, a redução de $15 \%$ no preço da energia no ACR leva a $\underline{T R}$ do empreendedor dos 12,5\%, do cenário referencial, para 7,9\%. A $\underline{T I R}$, no cenário referencial, está posicionada em patamar muito próximo ao limite de rentabilidade, de forma que decrementos diminutos nos preços de energia no ACR levariam a taxa do empreendedor ao patamar da atratividade setorial.

O preço de energia no ACR não é vetor de risco para o empreendedor, uma vez que é fixado contratualmente no momento do leilão. Entretanto, a observação do impacto de variações no preço da energia comercializada no ACR, nos indicadores da qualidade, justifica-se porque subsidia a decisão de investimento e a estratégia do empreendedor para participação nos leilões de outorga de novas concessões e de comercialização da energia.

- Variação do Percentual de Energia destinado à Comercialização no ACL

Na formatação do empreendimento protótipo, admitiu-se que $97 \%$ da energia assegurada é comercializada no ACR e os outros 3\% são reservados para cobertura de perdas na transmissão, de forma que, na simulação no cenário referencial, não foram observadas transações de venda de energia no ACL.

A definição do percentual de energia a ser destinado à comercialização no ACL é ponto substancial dentro do processo de tomada de decisão de empreender. O posicionamento do empreendedor frente ao mercado livre é o vetor indutor da incerteza de mercado ao processo decisório. Em contrapartida, a calibragem da exposição no ACL é um dos principais caminhos, através do qual o empreendedor pode extrair maior valor do negócio, relativamente aos demais agentes do mercado.

O empreendedor pode tomar caminhos distintos entre dois extremos. Ou destinar $100 \%$ de sua energia assegurada à comercialização no ACR, em contratos de 30 anos, extraindo do processo de decisão grande parte da incerteza sobre o comportamento futuro de preços da energia. Ou destinar o percentual mínimo de seu lastro de venda, definido pelo regulador, à comercialização no ACR e reservar o restante para contratação no ACL, em contratos com 
prazos e preços negociados bilateralmente. A decisão do empreendedor estará pautada na sua expectativa acerca do comportamento dos preços no ACL, ao longo do horizonte de análise. A decisão de exposição ao ACL altera a condição de risco do investimento.

Na Figura[5.13], a exposição pode ser medida pelo comprimento das faixas de retorno do empreendedor, quando percentuais distintos de comercialização no ACL são considerados. Percentuais maiores de energia no ACL implicam em maior exposição ao risco e maiores oportunidades de retorno, função do menor prazo e do padrão mais elevado de flutuação dos preços da energia nos contratos firmados no ambiente livre.

Para simulação da exposição no ACL, considerou-se que o preço de referência para energia comercializada neste ambiente flutua de maneira aleatória, com igual probabilidade, entre posições anuais limitadas pelas fronteiras de R\$ $62 \mathrm{MWh}$ e R \$ $170 \mathrm{MWh}$, respectivamente, fronteiras conservadora e agressiva.

Considerou-se que os contratos firmados pelo empreendedor, no ACL, estão, em proporções iguais, divididos entre contratos de 1,3 e 5 anos. Nestes contratos, arbitrou-se preço equivalente ao preço de referência para energia comercializada no ACL no ano de sua assinatura, fixo em moeda da base da análise, ao longo de toda sua vigência. Ao longo do ciclo operacional da usina, admitiu-se que os contratos são sempre integralmente renovados no seu vencimento, pelo preço de referência da energia no ACL no ano da renovação.

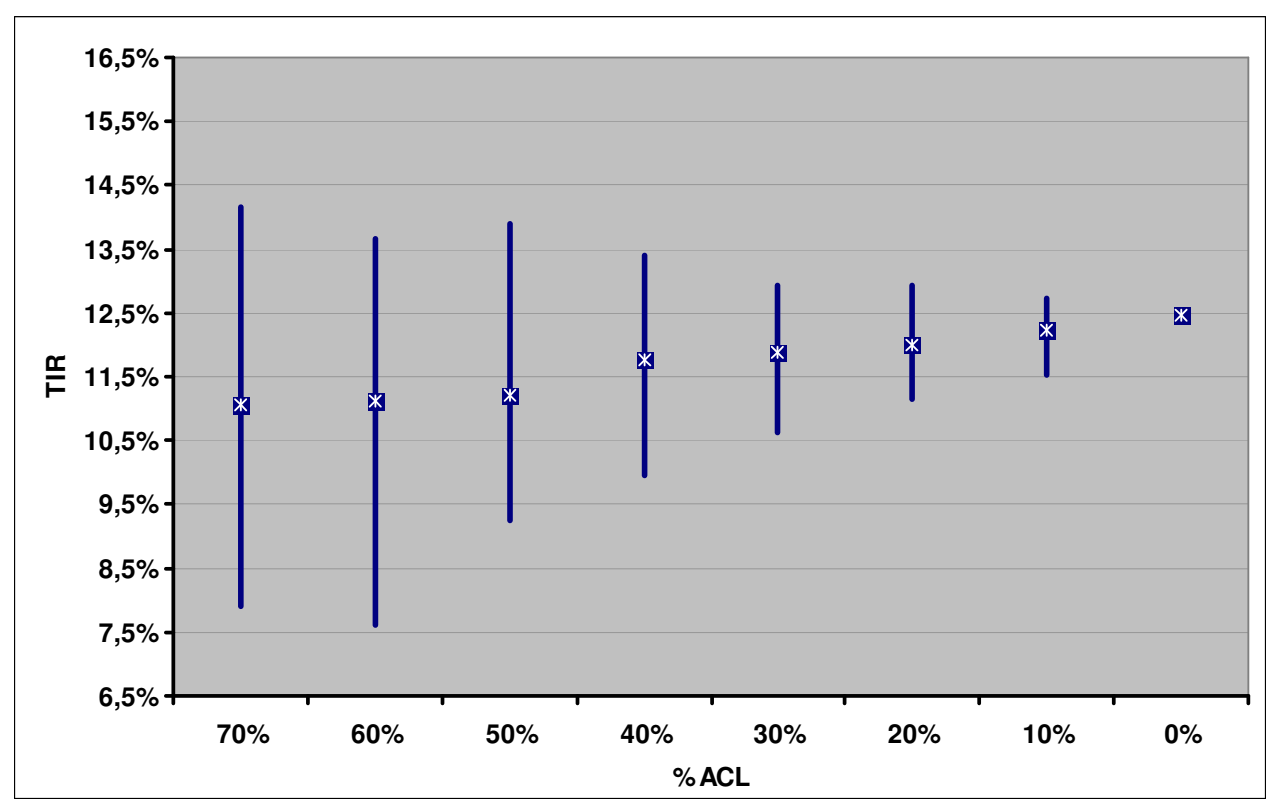

Figura 5.13 - Variação da Exposição no ACL 
- Flutuações nos Parâmetros de Inflação e Juros Variáveis.

Devido à aleatoriedade do comportamento das variáveis macroeconômicas e às correlações entre elas, a análise de sensibilidade considera variação dispersa das variáveis IPCA, ISC, ISEE e TJLP simultaneamente. Admitiu-se, para as quatro variáveis, oscilação entre as fronteiras impostas indicadas na Tabela[5.10], com posições anuais geradas randomicamente.

Os resultados na Figura[5.14] foram obtidos a partir do tratamento de uma amostra estatística do indicador $\underline{T I R}$ do empreendedor, a partir de cenários de geração randômica. Os resultados consideram o intervalo de confiança no qual poderá situar-se a média da variável $\underline{T I R}$, com introdução de um padrão de confiabilidade de $90 \%$.

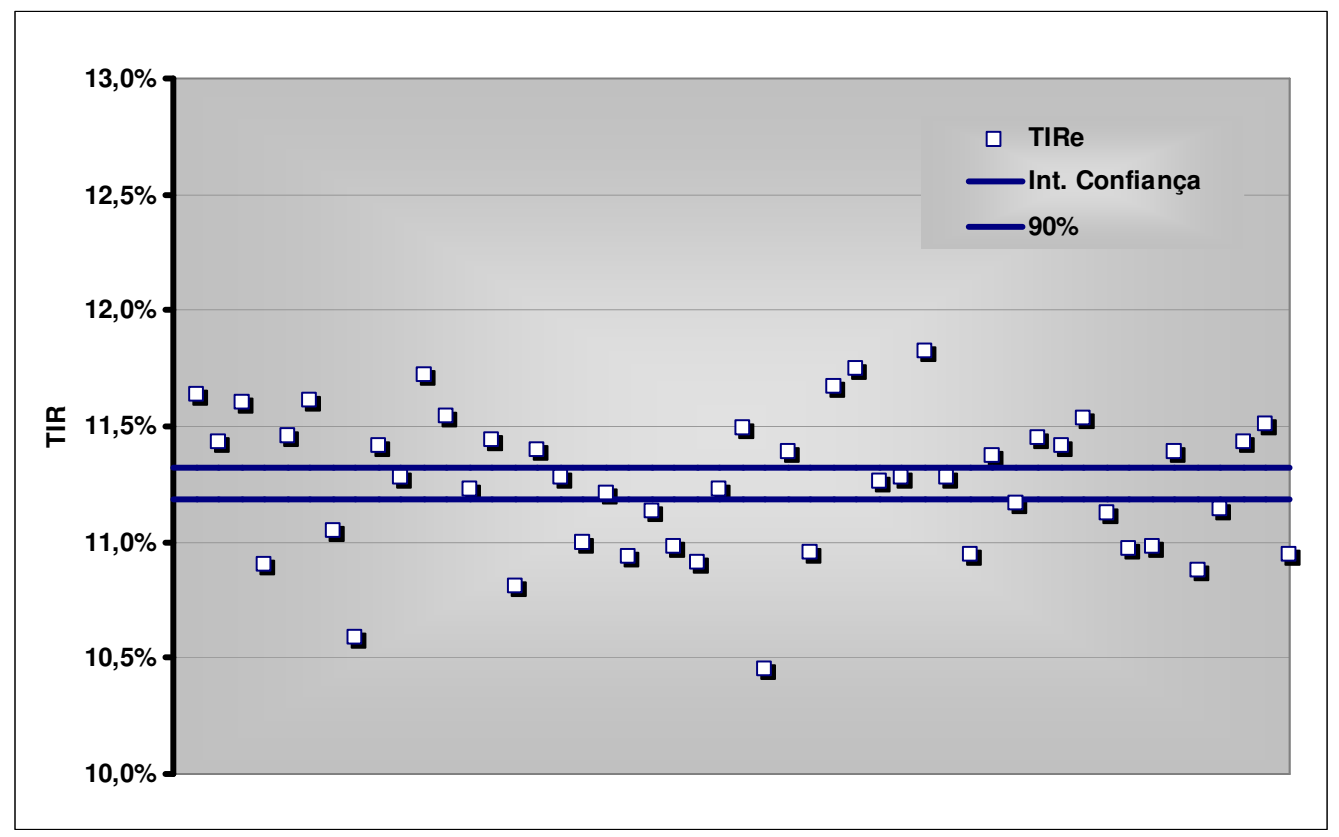

Figura 5.14 - Distúrbios Macroeconômicos

A Figura[5.14] ilustra o impacto moderado da flutuação das variáveis macroeconômicas nos indicadores da qualidade econômica do empreendimento. A média da $\underline{T I R}$ do empreendedor estará situada entre $11,3 \%$ e $11,2 \% \%$, ante $12,5 \%$ no cenário referencial. 


\subsubsection{Análise de Risco de Efeitos Cruzados}

$\mathrm{Na}$ análise de risco que considera efeitos cruzados, admite-se flutuação dispersa combinada de múltiplas variáveis do sistema empreendimento e de seu ambiente. Nesta seção, serão observados efeitos no indicador $\underline{T I R}$ do empreendedor e dos investidores nos TIEE-A2 da oscilação combinada de:

- Custo Unitário de Implantação

- Atrasos na Entrada em Operação Comercial

- Custo Unitário de Operação e Manutenção

- Quantidade de Energia Disponível

- Preço de Energia no Mercado de Curto Prazo - PLD

- Indicadores Macroeconômicos - IPCA, ISC, ISEE e TJLP

As fronteiras de comportamento, conservadora e agressiva, para cada variável estão discriminadas na Tabela[5.12]. Observar que, não necessariamente, as fronteiras de flutuação são as mesmas utilizadas para análise discreta, da Tabela[5.10].

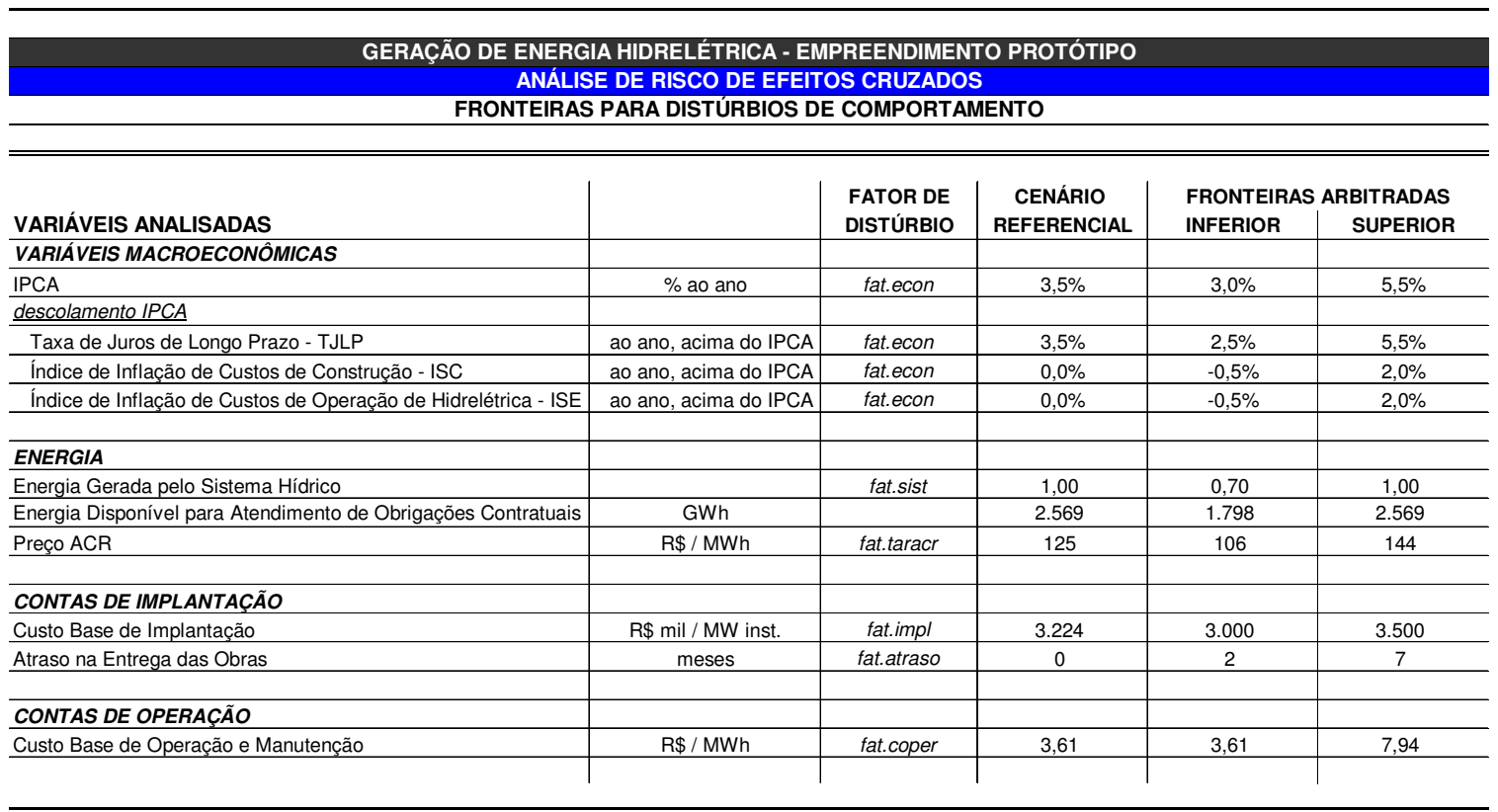

Tabela 5.12 - Fronteiras de Flutuação para Análise de Risco de Efeitos Cruzados

Por hipótese, admite-se que as variáveis acima não são correlacionáveis. Desta forma, toda a infinita família de cenários, resultante da combinação de posicionamentos das variáveis, 
definidos a partir de critério randômico, dentro das fronteiras limites arbitradas, tem igual validade e probabilidade de ocorrência.

Não obstante se reconheça que poderiam ser presumidas correlações entre as variáveis preços no ACL, PLD e Energia Disponível, porque são todas variáveis vinculadas ao equilíbrio entre oferta, demanda e preços de energia no mercado, entende-se que a dificuldade para estabelecer e sustentar eventuais correlações acabam por legitimar a hipótese aqui assumida.

Entre as demais variáveis, não se percebe quaisquer possíveis correlações. Destaca-se que a correlação, de fato existente, entre os distintos índices de inflação, bem como entre estes e a TJLP, está respeitada na análise, uma vez que estes parâmetros foram arbitrados, não em valor absoluto, mas a partir do seu descolamento em relação ao IPCA.

- Análise de Risco de Efeitos Cruzados da Flutuação das Variáveis Quantidade de Energia Disponível e PLD.

Antes de ingressar na análise combinada do conjunto de variáveis, isolamos as variáveis associadas à quantidade e preços de energia, para reconhecer os efeitos na $\underline{T I R}$ do empreendedor de flutuações de variáveis, cujos comportamentos estão presos ao ambiente setorial.

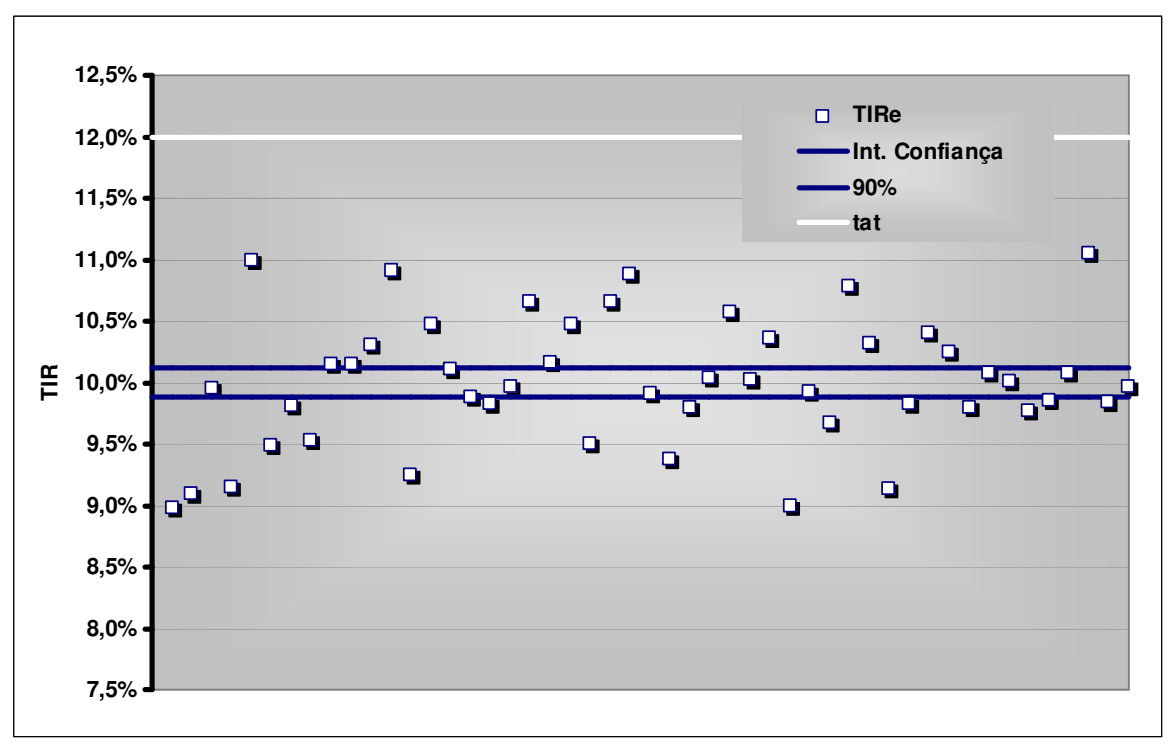

Figura 5.15 - Flutuação Dispersa e Cruzada da Quantidade de Energia Disponível e Preços 
A análise da Figura[5.15] mostra sensibilidade moderada do indicador $\underline{T I R}$ às variações simultâneas da quantidade de energia disponível e dos preços de energia. A média do indicador $\underline{T I R}$ está situada, com padrão de $90 \%$ de confiabilidade, dentro do intervalo de confiança de $9,9 \%$ e $10,1 \%$, ante os $12,5 \%$ no cenário referencial.

Observa-se que a flutuação da quantidade de energia, se analisada isoladamente, afeta sempre de maneira negativa a $\underline{T I R}$ do empreendedor, uma vez que, na fronteira agressiva, considerase que a energia disponível é igual à energia assegurada. A condição mais conservadora, por sua vez, assume energia disponível equivalente a $90 \%$ da energia assegurada.

Como a energia disponível é sempre igual ou inferior à energia assegurada, o empreendedor apresenta-se sempre em posição neutra (no particular cenário em que a energia disponível é igual à energia assegurada) ou devedora no mercado de curto prazo. Portanto, na análise de risco, pode-se considerar que o empreendedor, invariavelmente, adquire energia no mercado de curto prazo. Quando o PLD é inferior à média ponderada dos preços da energia nos CCEAR's, o empreendedor registra resultado positivo; quando ocorre situação contrária, o empreendedor aufere resultado negativo. Contudo, como mesmo a fronteira inferior do PLD é superior ao Custo Unitário de Operação e Manutenção da usina protótipo, sempre que a energia disponível é inferior à assegurada, os resultados são inferiores ao que seria obtido se a energia fosse gerada na usina ou a ela atribuída no âmbito do MRE.

O PLD mínimo foi arbitrado em 62 [R \$ base/MWh], valor equivalente ao PLD médio do ano de 2006, ponderado pelo consumo em cada submercado de energia. O PLD máximo foi arbitrado em 300 [R \$ base/MWh].

Vale observar que os limites para o PLD vigentes em 2006, fixados por ANEEL (2005e), foram 17 [R \$/MWh] e 516 [R $\$ / M W h]$.

Entende-se que não teria sentido arbitrar a fronteira inferior do PLD no patamar de 17 [R $\$ / M W h]$, porque este valor refletiria um cenário de excesso de energia hídrica despachada, situação não condizente com os cenários de geração hídrica inferior à assegurada, gerados randomicamente na análise de risco. 
De outro lado, também não teria coerência arbitrar como fronteira superior o preço máximo homologado pela ANEEL. O preço máximo no patamar definido pela ANEEL representa situação de iminência de déficit de energia no sistema. Entende-se que esta situação refletiria crise no ambiente setorial, que não estaria associada apenas a um período hidrológico crítico, mas a desequilíbrios entre oferta e consumo, bem como deficiências no planejamento, regulação e operação setorial. Assim não teria sentido simulá-las, sob risco de enviesar a decisão do empreendedor, primeiro porque não se poderia arbitrar igual probabilidade de ocorrência, relativamente a outras posições de cenário, por se tratar de situação tópica, segundo porque situações de crise têm reflexo em todo o ambiente setorial e, usualmente, deflagram ampla mobilização para reposição da situação de equilíbrio. Importa aqui, apenas calibrar fronteira superior condizente com a condição de risco do empreendedor hídrico, que reflita o custo marginal de operação do sistema em situação de hidrologia crítica. Na análise de risco, admitiu-se tal valor igual a 300 [R $\$$ base/MWh].

- Análise de Risco de Efeitos Cruzados da Flutuação do Conjunto de Variáveis do Sistema Empreendimento e de seu Ambiente

Nesta seção foram analisados os efeitos da flutuação combinada do conjunto de variáveis nos indicadores $\underline{T I R}$ dos investidores nos TIEE-A2 e do empreendedor. A Figura[5.16] traz os efeitos na $\underline{T I R}$ dos investidores nos TIEE-A2 e a Figura[5.17] na $\underline{T I R}$ do empreendedor.

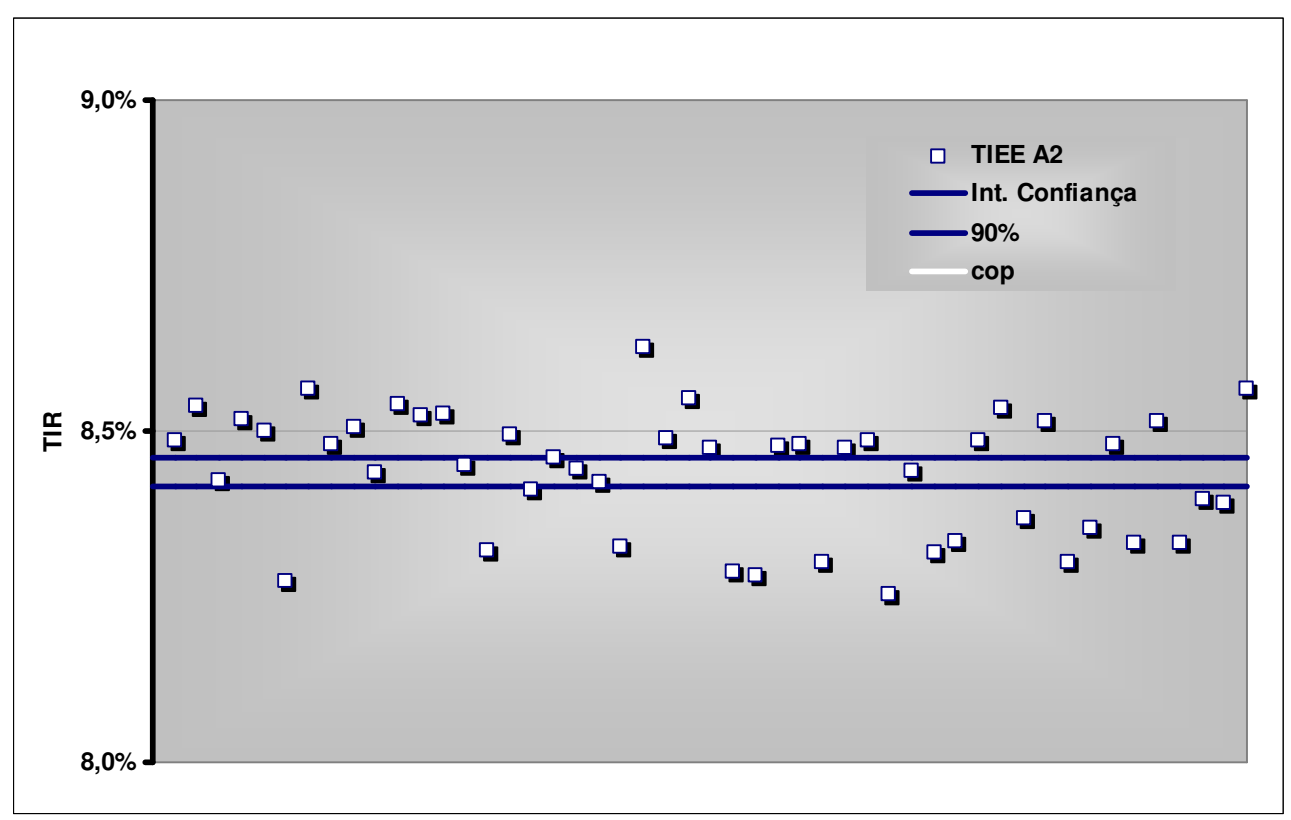

Figura 5.16 - Flutuação Dispersa do Conjunto de Variáveis - Impacto na $\underline{\text { TIR }}$ dos TIEE-A2 


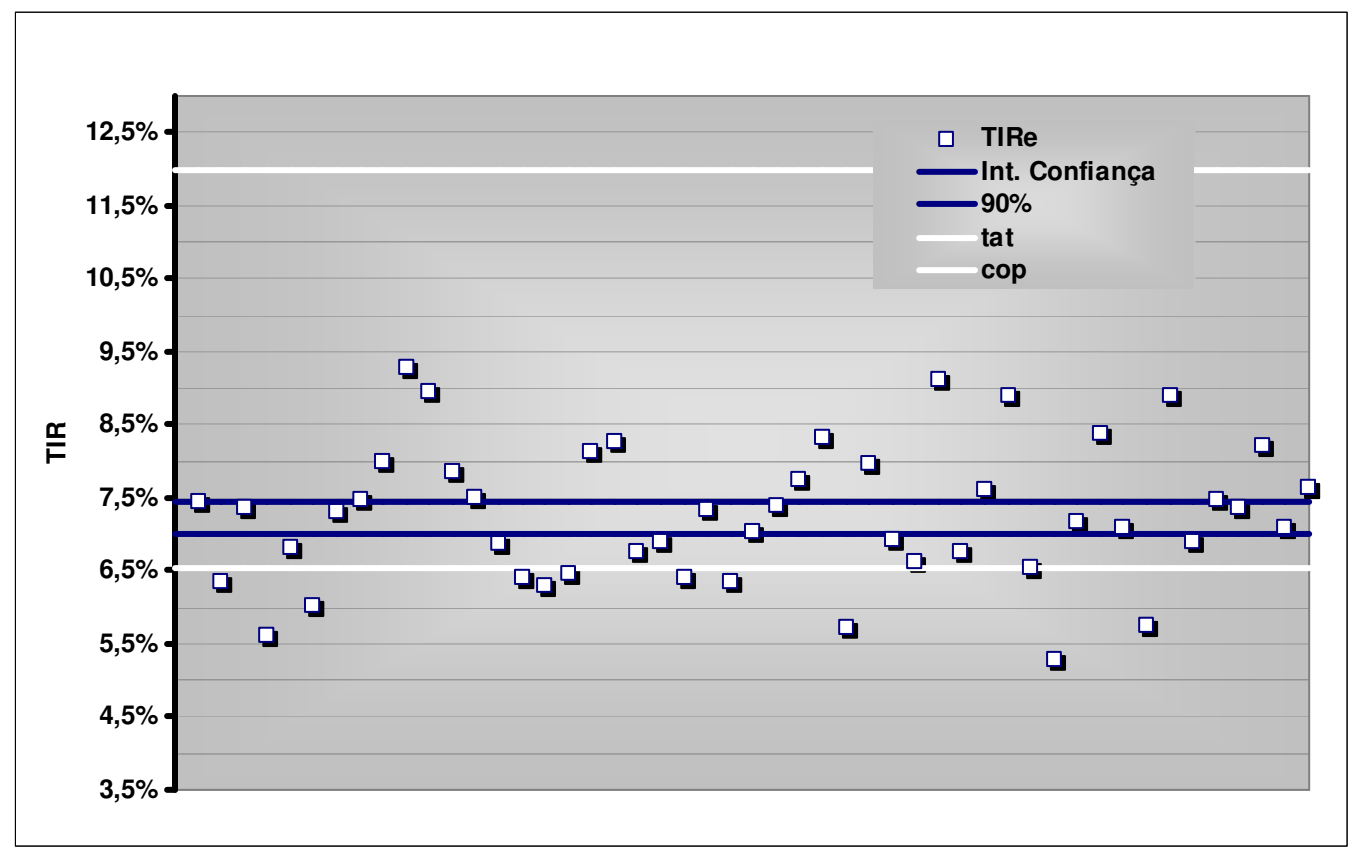

Figura 5.17 - Flutuação Dispersa do Conjunto de Variáveis - Impacto na $\underline{T I R}$ do Empreendedor

A exposição dos investidores nos TIEE-A2 é reduzida, como era de se esperar, porque apenas uma pequena parcela de seu vetor de retorno está vinculado ao desempenho do empreendimento.

Ademais, como o prêmio é calculado como percentual sobre a receita operacional líquida, está diretamente condicionado à posição dos preços da energia nos CCEAR's. O preço dos CCEAR's responde por $100 \%$ da receita operacional bruta do empreendimento e não varia ao longo de todo o horizonte da concessão, a menos por oscilações no IPCA, que implicam em flutuação no fator de perda inflacionária ${ }^{72}$, aplicado sobre o fluxo de encaixe de receitas e sobre o fluxo de juros recebidos em períodos mensais.

Como a estratégia do empreendedor não admite exposição no ACL, a exposição do investidor nos TIEE-A2 também resulta bastante reduzida. Por não contemplar a comercialização no

\footnotetext{
${ }^{72}$ Fator de perda inflacionária: (i) aplicado sobre o fluxo de receitas operacionais, reflete a perda de poder de compra da tarifa dentro de períodos anuais, verificada pelo fato dos encaixes de receita ocorrerem em períodos mensais e os reajustes tarifários em períodos de um ano e (ii) aplicado sobre os juros pagos aos investidores nos TIEE-A1 e TIEE-A2, que reflete a perda de poder de compra do fluxo de juros dentro de períodos anuais, verificada porque os juros são pagos em períodos mensais e o valor de face dos títulos, corrigido em períodos anuais.
} 
ACL, o fator de perda inflacionária acaba por ser o único vetor que faz a $\underline{T I R}$ dos TIEE-A2 oscilar. Nem mesmo variações na energia disponível afetam o valor da receita operacional bruta do empreendedor, uma vez que é admitido que, invariavelmente, nos CCEAR's e nos contratos no ACL, o empreendedor recebe pelo valor de placa dos contratos.

Pode ocorrer do gerador auferir receita adicional à proveniente dos CCEAR's nas situações em que a energia a ele atribuída após a aplicação do MRE seja superior à sua energia contratada. Nesta hipótese, a energia adicional seria liquidada no mercado de curto prazo, ao PLD. Contudo, na análise de risco considerou-se que a energia disponível é, na fronteira de flutuação agressiva, igual a energia assegurada da usina. Portanto, nesta rotina de análise, não se vêem situações em que a receita auferida pelo gerador supere aquela proveniente dos CCEAR's.

O impacto, da flutuação dispersa do conjunto de variáveis, na $\underline{T I R}$ do empreendedor, por outro lado, é intenso. O tratamento estatístico dos resultados obtidos a partir da amostra de múltiplos cenários gerados randomicamente mostra a $\underline{T I R}$ no intervalo de 7,0\% e 7,5\%, com coeficiente de confiabilidade de $90 \%$, frente ao valor de $12,5 \%$ simulado no cenário referencial. A $\underline{T I R}$ posiciona-se em patamar bastante inferior ao patamar da taxa de atratividade, mais próximo do piso de rentabilidade, na análise, referenciado pelo custo de oportunidade.

Observa-se, porém, que o impacto intenso na $\underline{T I R}$ reflete a postura do planejador, na calibragem das fronteiras de flutuação das variáveis aleatórias. As fronteiras foram arbitradas propositadamente, de modo geral, com viés para os limites conservadores, uma vez que o objetivo é transmitir ao empreendedor a imagem da sua exposição no negócio. No entanto, foram arbitradas com o cuidado de não reproduzir situações de crise, de quebra generalizada de cenário, cujo estudo não traria benefício algum à decisão. Não teria sentido tampouco, arbitrar fronteiras agressivas e conservadores eqüidistantes da posição do cenário referencial, porque o que se produziria seriam resultados médios coincidentes com os resultados extraídos no cenário referencial. Nem mesmo, calibrar fronteiras com viés agressivo, porque o que se produziria seriam posições possíveis de retorno, cuja visualização nada acrescentaria ao processo de decisão. 
Sob tal ressalva, a análise da Figura[5.17] mostra que, a taxa de retorno do empreendedor estará posicionada acima do patamar do custo de oportunidade, com confiabilidade de $90 \%$. Tal observação corrobora a referência ao padrão conservador do investimento em geração e permite enxergar o investimento no setor, como potencial destino de recursos de investidores conservadores na economia, seja pela via da participação acionária ou das debêntures, condição em que o investimento assume binômio Rentabilidade x Risco em patamar ainda mais conservador, próximo do padrão de comportamento dos ativos de renda fixa. 


\section{CONCLUSÕES}

Em 2004, o governo brasileiro promulgou as leis 10.847 e 10.848 estabelecendo novo marco na regulação do setor elétrico no Brasil. O marco de 2004 manteve o direcionamento regulatório das reformas verificadas ao longo da década de 90, mas introduziu novas regras para concessão de novos aproveitamentos hidrelétricos e para comercialização de energia elétrica, que afetam o fluxo de recursos privados e a qualidade dos investimentos no setor.

Neste contexto, lançou-se como proposta desta dissertação (i) identificar as implicações da nova regulação sobre o fluxo de investimentos privados para empreendimentos de geração hidrelétrica e (ii) produzir uma imagem da qualidade dos investimentos em geração hidrelétrica, ao gerar indicadores que permitissem comparar o investimento no setor frente a outros destinos de investimento disponíveis na economia. Com foco na resposta à proposta desta dissertação, mas não a ela limitadas, as conclusões e contribuições desta dissertação estão elencadas a seguir:

1. O novo modelo do setor elétrico e, especificamente, a sistemática instituída para contratação de energia elétrica no ACR, favorecem a modicidade tarifária e a competição no setor. A adoção do leilão de comercialização, sob critério de menor preço, para contratação da energia demandada pelas concessionárias de distribuição, constitui mecanismo eficiente para pressionar redução de preços da energia para o consumidor final e criar ambiente competitivo no segmento de geração. Adicionalmente, as restrições à verticalização de empresas do setor contribuem para criação de ambiente competitivo na geração.

2. Outrossim, a utilização do critério de menor preço da energia destinada à comercialização no ACR, como critério de licitação de novos aproveitamentos, revela a prioridade do objetivo de modicidade tarifária no âmbito do modelo regulatório vigente. A utilização do critério de menor preço em detrimento do critério de maior UBP parece mais eficiente neste aspecto, na medida em que os benefícios da concessão são revertidos ao consumidor final, de forma eficaz, porque refletem diretamente o preço da energia. Quando pelo critério de maior UBP, os benefícios da concessão originam-se do pagamento anual da outorga e são revertidos para o consumidor, em teoria, pela reinversão, por parte do 
Estado, dos recursos arrecadados. Tomando em conta que a tendência almejada nas reformas setoriais seja delegar, à gestão privada, o investimento no setor, e reservar ao Estado a função de regulador e formulador de políticas, a leitura da decisão pela não utilização do maior UBP, como critério de outorga da concessão, é positiva.

3. A instituição dos leilões de comercialização de energia, de cinco a três anos antes da realização da demanda, transmite maior segurança ao empreendedor de geração e contribui para elegibilidade do empreendimento frente a potenciais credores. A contratação prévia representa sinal para novos investimentos em geração, à medida que incrementa segurança ao processo de decisão de investimento. Aliado à prévia contratação, a fixação do prazo dos CCEAR's, em 30 anos para energia proveniente de novos empreendimentos hídricos, reduz a exposição do empreendedor de geração que decide pela comercialização da energia no ACR. Também, a pulverização dos contratos e a exigência de eliminação das obrigações intra-setoriais como condição para repasse dos custos, ao consumidor final, por parte dos distribuidores, contribuem para redução do risco de inadimplemento a que se expõe o gerador.

4. A divisão do mercado em livre e regulado acrescenta à decisão de investimento aspecto peculiar, ao permitir que o investidor altere a condição de risco do negócio, pela definição do montante de energia destinado a cada mercado.

Enquanto a comercialização no ACR torna extremamente reduzida a exposição do empreendedor e lhe impõe um cenário de renda segura, com baixa flutuação por um prazo de 30 anos, a decisão pela comercialização no ACL permite ao empreendedor aumentar sua exposição, ao abrir perspectivas de contratação em prazos menores, em data próxima da data de realização da demanda e por preços, cuja tendência de comportamento seja acompanhar com algum descolamento, no médio e longo prazos, a evolução dos preços de energia no mercado.

A possibilidade de ajustar a posição do binômio Rentabilidade $x$ Risco entre patamares conservador e agressivo, pela definição da estratégia de comercialização, permite ao empreendedor calibrar a exposição no negócio. O empreendedor pode, por exemplo, fixar o percentual de contratação no ACR, tendo em vista atingir determinado piso de rentabilidade ou cobrir com segurança suas necessidades de caixa, destinando o restante à comercialização no ACL, caso suas expectativas apontem para um cenário de preços no ACL mais atrativo que no ACR. 
5. Os resultados da análise da qualidade do investimento a partir do protótipo revelam padrão de rentabilidade do empreendedor pouco superior à taxa de atratividade arbitrada, para preços equivalentes ao preço máximo para energia hídrica do leilão de outubro de 2006 e parâmetros de [Custo de Implantação/Potência Instalada] e [Garantia Física/Potência Instalada] médios, considerando os empreendimentos concedidos em $\mathrm{dez} / 05$ e out/06.

Se analisarmos os leilões de dez/05 e o leilão de out/06 de forma isolada e atribuirmos a atratividade do empreendimento à relação [Custo de Implantação/Potência Instalada] e [Garantia Física/Potência Instalada], concluiremos que os empreendimentos licitados no leilão de 2005 têm reduzida atratividade em relação aos licitados em out/06.

Considerando a média ponderada para os parâmetros de [Custo de Implantação/Potência Instalada] divulgados, ao preço médio da energia com o qual foram arrematados, com demais variáveis de comportamento e ambiente na posição em que foram parametrizadas no empreendimento protótipo, especula-se taxa interna de retorno no patamar de $8 \%$ ao ano, efetiva acima da inflação, para os empreendimentos concedidos em dez/05. De forma análoga, para os empreendimentos concedidos em out/06, taxa interna de retorno de $15 \%$ ao ano, efetiva acima da inflação.

6. Como outros empreendimentos intensivos em capital e de longo prazo de maturação, a análise econômica mostrou maior sensibilidade dos indicadores da qualidade às perturbações nas variáveis associadas aos custos de implantação do empreendimento e à receita operacional.

Entretanto, de modo geral, nas análises apoiadas em cenários de geração randômica, a taxa de retorno do empreendedor resultou superior ao custo de oportunidade, considerando padrão de confiabilidade de 90\%, mesmo tendo adotado viés conservador na arbitragem das fronteiras de comportamento das variáveis. Ao empreendedor que destina a maior parte de sua energia assegurada à comercialização no ACR, os riscos ao longo do ciclo operacional estão associados, essencialmente, à geração inferior à energia assegurada e à conseqüente exposição ao comportamento do preço de energia no curto prazo.

A análise realizada a partir de cenários de geração randômica, onde atribui-se flutuação dispersa simultânea apenas das variáveis de preço e quantidade de energia, mostrou distensão moderada da taxa de retorno em relação à posição no cenário referencial, 
revelando relativa capacidade de suporte do empreendimento, para desvios nas variáveis que se vinculam aos riscos hidrológicos.

7. Ainda que a análise tenha revelado relativa capacidade de suporte do empreendimento aos riscos que se vinculam à hidrologia, quer parecer que a alocação do risco hidrológico ao empreendedor hídrico, nos CCEAR's firmados na modalidade quantidade de energia, é ponto frágil da estrutura do modelo setorial, uma vez que o gerador não tem nenhum poder de gestão sobre este vetor de risco.

Em verdade, a hidrologia constitui um vetor de risco inerente ao modelo predominantemente hídrico brasileiro, sobre o qual não há nenhum agente setorial com poder de gestão, senão o ONS, que exerce algum controle, ao hierarquizar o despacho energético, com olhos na melhor utilização dos volumes armazenados nos reservatórios. Diante de tal constatação, é esperável que as taxas de atratividade do empreendedor hídrico reflitam a não gerência sobre o risco hidrológico ou, em outros termos, a tendência é que o preço da energia hídrica seja mais alto para o consumidor final, porque a taxa de atratividade do empreendedor hídrico tem de cobrir sua falta de gestão sobre um risco cujo ônus lhe foi simplesmente imputado, no desenho do novo modelo setorial.

A conclusão natural que daí deriva é a de que a alternativa menos onerosa para o consumidor final seria aquela em que todos os contratos fossem firmados na modalidade disponibilidade de energia. Nesta configuração, seria assegurado a cada gerador um fluxo de ingressos operacionais, necessário e suficiente para devolver e remunerar os recursos imobilizados na usina e, apenas quando a usina fosse despachada pelo ONS, seria adicionado à esta parcela fixa, um montante necessário para cobrir os custos variáveis incorridos pelo empreendedor, para atender à ordem de despacho do ONS.

Assim, os consumidores veriam assegurada a expansão da geração pelo menor custo, porque as decisões de investimentos pelos empreendedores hídricos seriam tomadas numa condição de menor risco e, portanto, sob a pretensão de menores taxas de retorno e porque o custo de operação do sistema, para o consumidor final, refletiria sempre a alternativa de menor custo, porque derivaria diretamente da ordenação de despacho por mérito econômico, coordenada pelo ONS.

8. A análise da qualidade do investimento mostrou que o empreendimento oferece taxas efetivas de retorno similares para configurações de fundos que consideram alternativamente (i) Recursos Próprios + BNDES e (ii) Recursos próprios + debêntures. 
Apesar do custo reduzido do funding provido pelo BNDES, a consideração de duas emissões casadas, com substituição do perfil da dívida ao término da implantação, revelou-se competitiva enquanto alternativa de funding para o empreendedor.

A primeira emissão, integralizada ao longo do ciclo de implantação do empreendimento, tem custo equivalente ao das emissões realizadas em 2006 por empresas integradas do setor elétrico - aproximadamente $104 \%$ do CDI - e reflete um padrão de remuneração mais alto como reflexo da necessidade de cobertura dos riscos de construção. A segunda emissão, cujos recursos são utilizados para resgate da primeira, é integralizada no ano posterior ao ano de término da implantação e oferece remuneração menor ao investidor, como contrapartida da não necessidade de cobertura dos riscos de construção.

A utilização da rolagem da dívida permite ao empreendedor reduzir o custo financeiro do empreendimento e diferir a amortização em prazos longos, maximizando a disposição de seu fluxo de retorno no empreendimento. A segunda emissão tem parte de sua remuneração vinculada ao desempenho do empreendimento. O prêmio, calculado como percentual sobre a receita operacional líquida do empreendimento, permite ao empreendedor compartilhar parte do risco de mercado com investidores nos títulos.

Outro aspecto que eleva as emissões, como alternativa para captação de recursos de longo prazo, refere-se ao fato de que as debêntures são formatadas tendo por base as condições peculiares do empreendimento ao qual se vinculam. No caso do empreendimento protótipo, as debêntures resultantes da segunda emissão têm, por exemplo, prazo compatível com o payback do empreendedor no empreendimento e custo indexado ao IPCA, índice de evolução do preço de energia nos CCEAR's, o que contribui para reduzir a exposição do empreendedor no empreendimento.

9. Do ponto de vista do investidor, a debênture com prêmio vinculada à receita auferida pelo empreendimento está associada a um padrão reduzido de riscos. Na análise apoiada em cenários de geração randômica, a média da taxa de retorno do investidor nos títulos da segunda emissão será de 8,47\% ao ano, efetiva acima da inflação, para uma posição no cenário referencial de $8,66 \%$.

As debêntures com lastro em ativos constituem canal alternativo para a derivação de capital de investidores institucionais aos ativos de infra-estrutura. O cenário de perspectivas de queda de juros básicos na economia, com redução da rentabilidade oferecida pelos títulos públicos federais, sugere alterações nos perfis das carteiras de investidores institucionais, que atualmente concentram posições em ativos de renda fixa 
desta natureza. A tendência é o aumento da demanda por produtos de crédito associados ao setor privado.

Neste panorama, ativos de infra-estrutura figuram como destinos potenciais para recursos de investidores institucionais, primeiro pela demanda elevada por recursos verificada no setor, segundo, pelo risco contido e pelos longos prazos de maturação dos investimentos e, terceiro, pela possibilidade de retornos em patamares sensivelmente superiores ao do investimento em títulos públicos com perfil de longo prazo.

10. Quer parecer que o canal atualmente mais disseminado para participação de investidores institucionais em empreendimentos de geração de energia elétrica seja a aquisição de cotas dos Fundos de Investimentos em Participações (FIP's). Como o investimento em geração revelou-se, na análise da qualidade, conservador, mesmo sob o ponto de vista do empreendedor, os FIP's devem preponderar enquanto veículo para o ingresso de capital de investidores não especialistas no setor. Contudo, enxerga-se também as debêntures com lastro em ativos, enquanto produto de investimento alternativo às cotas dos FIP's, como mecanismo para mobilização de capital de investidores institucionais para empreendimentos de geração.

As debêntures não constituem canal de captação concorrente, mas sim complementar, aos FIP's. Enquanto o investimento em cotas de FIP's é opção para a composição da parcela de renda variável da carteira do investidor institucional, as debêntures, da forma como desenhadas nesta dissertação, têm perfil muito similar aos produtos de investimento em renda fixa disponíveis no mercado, essencialmente títulos públicos federais.

A atração de fontes alternativas de capital para empreendimentos de geração de energia elétrica constitui questão estrutural, no ambiente setorial, tendo em vista a demanda anual por investimentos em geração, da ordem de $\mathrm{R} \$ 7,5$ bilhões por ano, para incremento da capacidade instalada em 4.100 MW anuais.

Com bases regulatórias sólidas, em um cenário de disponibilidade de recursos e abundância de instrumentos na economia para acesso a recursos de poupança privada, cabe ao Estado assegurar ambiente propício para os novos investimentos no setor, por meio de planejamento diretivo e regulação transparente, da promoção de isonomia competitiva entre empresas públicas e privadas e, sobretudo, do balanceamento entre modicidade tarifária e rentabilidade para novos investimentos. 


\section{ANEXO A - CARACTERÍSTICAS DOS EMPREENDIMENTOS CONCEDIDOS EM DEZ/05 E OUT/06}

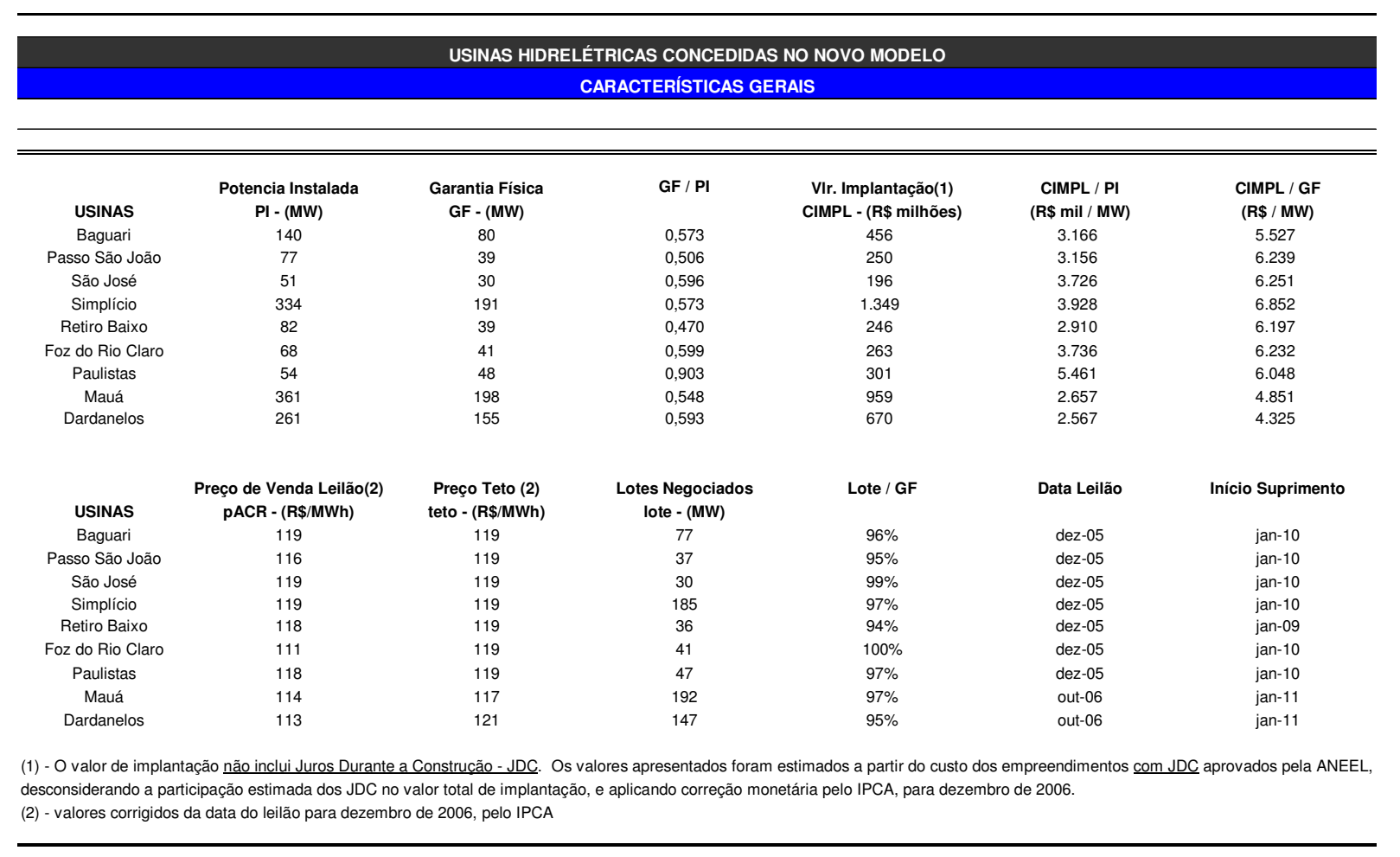

Empreendimentos Hidrelétricos Concedidos (dez/05 e out/06) 
ANEXO B - FLUXO DE CAIXA DO EMPREENDIMENTO PROTÓTIPO

(Cenário Referencial) 
GERAÇÃO DE ENERGIA HIDRELÉTRICA - EMPREENDIMENTO PROTÓTIPO FLUXOS VINCULADOS A IMPLANTAÇÃO

\begin{tabular}{|c|c|c|c|c|c|c|c|c|c|c|c|c|c|c|c|c|c|}
\hline \multirow[b]{2}{*}{ Ano Ref. } & \multicolumn{2}{|c|}{ CUSTO IMPLANTAÇÃO } & \multicolumn{3}{|c|}{ BNDES } & \multicolumn{5}{|c|}{ EMISSÃO NÃO PERFORMADA - DÍVIDA SENIOR } & \multicolumn{5}{|c|}{ EMISSÃO PERFORMADA } & \multicolumn{2}{|c|}{ TOTAL } \\
\hline & Pré-Obra & Obra & Encaixe & $\begin{array}{c}\text { Juros + } \\
\text { Encargos }\end{array}$ & Amortiz. & Integraliz. & Juros & Prêmio & Resgate & $\begin{array}{c}\text { Contas } \\
\text { Securitiz. }\end{array}$ & Integraliz. & Juros & Prêmio & Resgate & $\begin{array}{c}\text { Contas } \\
\text { Securitiz. }\end{array}$ & $\begin{array}{l}\text { Movi. } \\
\text { Financ. } \\
\end{array}$ & Fluxo \\
\hline $\begin{array}{l}1 \\
2 \\
3 \\
4 \\
5 \\
\end{array}$ & $\begin{array}{l}(82.212) \\
(20.553) \\
(20.553) \\
(20.553)\end{array}$ & $\begin{array}{l}(295.963) \\
(443.945) \\
(517.936) \\
(221.972)\end{array}$ & $\begin{array}{r}125.784 \\
188.677 \\
220.123 \\
94.338 \\
\end{array}$ & (1.258) & (16.976) & $\begin{array}{l}146.575 \\
203.334 \\
253.648 \\
149.876 \\
\end{array}$ & $\begin{array}{l}(14.429) \\
(34.445) \\
(59.414)\end{array}$ & & & $\left.\begin{array}{r}(21.041) \\
(250) \\
(250) \\
(250)\end{array}\right]$ & - & & 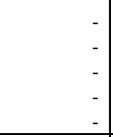 & & & $\begin{array}{l}(82.212) \\
(66.455) \\
(87.166) \\
(99.413) \\
(67.245) \\
\end{array}$ & $\begin{array}{r}(82.212) \\
(148.667) \\
(235.833) \\
(335.247) \\
(402.491)\end{array}$ \\
\hline$\frac{6}{6}$ & & & & $(42.559)$ & $(51.468)$ & & $(74.168)$ & & $\begin{array}{l}(753.433) \\
\end{array}$ & (250) & 753.433 & & & & $(22.853)$ & $(191.298)$ & $\frac{(40<.491)}{(593.790)}$ \\
\hline 7 & - & & - & (39.743) & (52.013) & & & & & & & (48.209) & (17.639) & (50.229) & & (208.083) & $(801.873)$ \\
\hline 8 & - & & - & $(36.863)$ & (52.564) & & & & & & & (44.995) & $(16.355)$ & (50.229) & (250) & $(201.256)$ & (1.003.129) \\
\hline 9 & - & & & $(33.917)$ & $(53.121)$ & - & & & & & 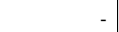 & $(41.781)$ & $(15.076)$ & $(50.229)$ & (250) & (194.374) & (1.197.504) \\
\hline 10 & & & & $(30.905)$ & (53.683) & - & & & & & & (38.567) & (13.674) & (50.229) & (250) & (187.308) & $(1.384 .812)$ \\
\hline 11 & & & & $(27.825)$ & $\frac{(35.252)}{(54.252)}$ & -2 & & & & & & $\frac{(30.354)}{(35.354)}$ & $\frac{(11.074)}{(12.363)}$ & $\frac{1}{(50.229)}$ & (250) & $(180.272)$ & $(1.565 .083)$ \\
\hline 12 & & & & (24.676) & (54.826) & - & & & & & & $(32.140)$ & (11.117) & $\begin{array}{l}(50.229) \\
\end{array}$ & (250) & (173.238) & $(1.738 .322)$ \\
\hline 13 & & & & $(21.458)$ & (55.407) & . & & & & & & (28.926) & $(9.874)$ & $\begin{array}{l}(50.229) \\
\end{array}$ & (250) & $\begin{array}{l}(166.144) \\
\end{array}$ & $(1.904 .465)$ \\
\hline 14 & & & & $\begin{array}{l}(18.169) \\
\end{array}$ & (55.994) & - & & & & & & (25.712) & (8.633) & $\begin{array}{l}(50.229) \\
\end{array}$ & (250) & (158.986) & (2.063.451) \\
\hline 15 & & & & (14.807) & (56.587) & . & & & & & & (22.498) & (7.314) & $\begin{array}{l}(50.229) \\
\end{array}$ & (250) & (151.684) & $(2.215 .136)$ \\
\hline 16 & & & & $(11.373)$ & $(57.186)$ & & & & & & & $(19.284)$ & $(6.061)$ & $(50.229)$ & (250) & (144.382) & $(2.359 .517)$ \\
\hline 17 & & & & $(7.864)$ & (57.791) & - & & & & & & (16.070) & $(4.848)$ & $(50.229)$ & (250) & (137.051) & (2.496.569) \\
\hline 18 & & & & $(4.279)$ & (58.403) & - & & & & & & (12.856) & (3.635) & $(50.229)$ & (250) & (129.652) & (2.626.221) \\
\hline 19 & & & & $(1.236)$ & $(39.348)$ & - & & & & & & $(9.642)$ & (2.423) & $(50.229)$ & (250) & $(103.127)$ & $(2.729 .349)$ \\
\hline 20 & & & & & & - & & & & & & $(6.428)$ & (1.211) & (50.229) & (250) & $(58.118)$ & $(2.787 .467)$ \\
\hline 21 & & & & & & - & & & & & & $(3.214)$ & & $(50.229)$ & (250) & (53.693) & $(2.841 .159)$ \\
\hline 22 & & & & & & - & & & & & & & & & & & $(2.841 .159)$ \\
\hline 23 & & & & & & - & & & & & & & & & & & (2.841.159) \\
\hline $\begin{array}{l}24 \\
25\end{array}$ & & & & & & - & & & & & & & & & & & $(2.841 .159)$ \\
\hline$\frac{25}{26}$ & & & & & & & & & & & & & - & & & & $(2.841 .159)$ \\
\hline 27 & & & & & & - & & & & & & & 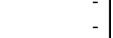 & & & & $\begin{array}{l}(2.84 .1 .1 .15 \\
(2841.59\end{array}$ \\
\hline 28 & & & & & & . & & & & & & & . & & & & $(2.841 .159)$ \\
\hline 29 & & & & & & & & & & & & & & & & & $(2.841 .159)$ \\
\hline 30 & & & & & & . & & & & & & & & & & & $(2.841 .159)$ \\
\hline 31 & & & & & & & & & & & & & & & & & $(2.841 .159)$ \\
\hline 32 & & & & & & & & & & & & & - & & & & $(2.841 .159)$ \\
\hline 33 & & & & & & & & & & & & & & & & & (2.841.159) \\
\hline $\begin{array}{l}34 \\
35\end{array}$ & & & & & & & & & & & & & & & & & $\begin{array}{l}(2.841 .159) \\
(2.841 .159)\end{array}$ \\
\hline$-T^{2}$ & & & & & 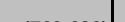 & & & & 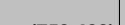 & 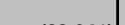 & & & & 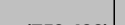 & 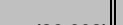 & & \\
\hline Total & (143.871) & $(1.479 .816) \mid$ & 628.922 & (329.775) & $(769.620) \mid$ & 753.433 & (182.457)] & & $(753.433)$ & (22.041)| & 753.433 & $(385.675)$ & (130.224) & $(753.433)$ & (26.603) & (2.841.159) & \\
\hline
\end{tabular}




\begin{tabular}{|c|c|c|c|c|c|c|c|c|c|c|c|c|c|}
\hline \multirow[b]{2}{*}{ Ano Ref. } & \multirow[b]{2}{*}{$\begin{array}{l}\text { Receita } \\
\text { ACR }\end{array}$} & \multirow[b]{2}{*}{$\begin{array}{l}\text { Receita } \\
\mathrm{ACL}\end{array}$} & \multirow[b]{2}{*}{$\begin{array}{l}\text { Receita } \\
\text { Transt. MRE }\end{array}$} & \multicolumn{6}{|c|}{$\begin{array}{c}\text { GERACAO DE ENERGIA HIDRELETRICA- EMPREENDIMENTO PROTOTIPO } \\
\text { DEMONSTRACGAO DE RESUTAAD (PARA CALCULO DO IR/CS) } \\
\text { Valores em R\$ } \$ \text { base mil } \\
\end{array}$} & \multirow[b]{2}{*}{\begin{tabular}{|c} 
Despesas \\
com Juros \\
\end{tabular}} & \multirow[b]{2}{*}{$\begin{array}{l}\text { Lucro antes } \\
\text { de IR/CS }\end{array}$} & \multirow[b]{2}{*}{ IR/CS } & \multirow[b]{2}{*}{ Lucro Líquidd } \\
\hline & & & & $\begin{array}{c}\text { Receita } \\
\text { Transt. SPOT }\end{array}$ & $\begin{array}{l}\text { Receita } \\
\text { Bruta }\end{array}$ & $\begin{array}{l}\text { Impostos } \\
\text { s/ receita }\end{array}$ & $\begin{array}{l}\text { Encargos } \\
\text { Setoriais }\end{array}$ & $\begin{array}{c}\text { Custos } \\
\text { Operacionais }\end{array}$ & Depreciaçăo & & & & \\
\hline $\begin{array}{l}1 \\
2 \\
3 \\
4 \\
5 \\
\end{array}$ & 255.515 & & & (25.749) & 229.766 & (12.397) & (22.676) & (11.617) & (95.384) & $(72.260)$ & 15.434 & $(7.217)$ & 161.006 \\
\hline $\begin{array}{c}6 \\
7 \\
8 \\
9 \\
10\end{array}$ & $\begin{array}{l}306.618 \\
306.618 \\
306.618 \\
306.618 \\
306.618\end{array}$ & & & & $\begin{array}{l}306.618 \\
306.618 \\
306.618 \\
306.6618 \\
306.618\end{array}$ & $\left.\begin{array}{l}(15.437) \\
(15.869) \\
(16.286) \\
(16.689) \\
(16.970)\end{array}\right)$ & $\begin{array}{l}(33.063) \\
(33.059) \\
(33.054) \\
(33.050) \\
(33.020)\end{array}$ & $\begin{array}{l}(16.553) \\
(16.54) \\
(16.532) \\
(16.52) \\
(16.445)\end{array}$ & 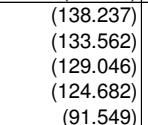 & $\begin{array}{c}(116.727) \\
(105.591) \\
(98.213) \\
(90.775) \\
(83.146)\end{array}$ & $\begin{array}{c}(13.400) \\
1.994 \\
13.486 \\
24.900 \\
62.708\end{array}$ & 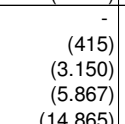 & $\begin{array}{l}217.341 \\
233.901 \\
230.778 \\
227.688 \\
215.751\end{array}$ \\
\hline $\begin{array}{l}11 \\
12 \\
13\end{array}$ & $\begin{array}{l}306.618 \\
300.618 \\
306.618\end{array}$ & & & & $\begin{array}{l}30.6618 \\
306.668 \\
306.618\end{array}$ & $\begin{array}{l}(21.326) \\
(21.559) \\
(21.784)\end{array}$ & 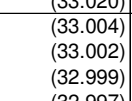 & $\begin{array}{l}(1.04606) \\
(16.4600) \\
(16.364) \\
(16.390)\end{array}$ & $\left.\begin{array}{l}(7.14484) \\
(71.965) \\
(69.932)\end{array}\right)$ & $\begin{array}{l}(0.1401) \\
(76.541) \\
(6.933) \\
(65.258)\end{array}$ & $\begin{aligned} 82.108 \\
85.857 \\
15.759 \\
105.651\end{aligned}$ & 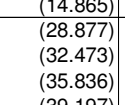 & $\begin{array}{l}215.51 \\
200.233 \\
196.429 \\
192.864\end{array}$ \\
\hline $\begin{array}{l}14 \\
15\end{array}$ & $\begin{array}{l}306.618 \\
306.618\end{array}$ & & & & $\begin{array}{l}306.6618 \\
306.618\end{array}$ & $\left.\begin{array}{l}(22.001) \\
(25.307)\end{array}\right]$ & $\begin{array}{l}(32.9977) \\
(32.964)\end{array}$ & $\left(\begin{array}{l}(16.3899) \\
(16.306)\end{array}\right)$ & {$\left[\begin{array}{l}667.180) \\
(3.1 .13888\end{array}\right]$} & $\begin{array}{l}(52.514) \\
(44.619)\end{array}$ & $\begin{array}{l}115.537 \\
155.033\end{array}$ & $\left.\begin{array}{l}(39.1977 \\
(5.2 .966)\end{array}\right]$ & $\begin{array}{l}189.310 \\
172.367\end{array}$ \\
\hline 16 & 306.618 & & & & 306.618 & (26.901) & $(32.948)$ & (16.267) & $(14.133)$ & $(36.717)$ & $\begin{array}{l}179.652 \\
17.652\end{array}$ & $\frac{(3.2 .900)}{(60.997)}$ & $\frac{1 / 2.367}{162815}$ \\
\hline $\begin{array}{l}17 \\
18\end{array}$ & & & & & & (26.945) & $(32.948)]$ & (16.265) & (13.655) & & & & $\begin{array}{l}162.815 \\
159.943\end{array}$ \\
\hline 19 & & & & & & 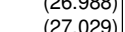 & 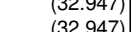 & $(16.264)]$ & (1) & (20). & & & \\
\hline 20 & & & & & & (27.069) & $(32.947)$ & (16.262) & $(12.316)$ & (7.639) & $\begin{array}{l}210.385 \\
210.351\end{array}$ & $\left.\begin{array}{l}(66.3888) \\
(71.446)\end{array}\right]$ & $\begin{array}{l}159.117 \\
162.414\end{array}$ \\
\hline $\begin{array}{l}21 \\
22\end{array}$ & & & & & 306. & (27.107) & $(32.946)$ & $(16.261)$ & $(11.899)$ & $(3.214)$ & 215. & (73.079) & 149.824 \\
\hline 23 & $\begin{array}{l}3006.6 \\
306.6\end{array}$ & & & & $\begin{array}{l}\begin{array}{l}306.6618 \\
306.618\end{array} \\
3\end{array}$ & (2). $\left.\begin{array}{l}(27.145) \\
27.1800\end{array}\right)$ & $\begin{array}{l}\left(\begin{array}{l}(32.9446) \\
(32.945)\end{array}\right) \\
\text { (a) }\end{array}$ & $\left.\begin{array}{l}(16.260) \\
(16.260)\end{array}\right)$ & $\begin{array}{l}(11.49) \\
(11.108)\end{array}$ & & $\begin{array}{l}218.710 \\
210124\end{array}$ & $\left.\mid \begin{array}{l}(7.4 .382) \\
(7.502)\end{array}\right)$ & $\begin{array}{l}148.486 \\
148.331\end{array}$ \\
\hline 5 & & & & & & (27.215)] & $(32.945)$ & (16.259) & & & & (74.619) & 148.181 \\
\hline$\frac{25}{26}$ & & & & & & $\frac{(27.249)}{(27.281)}$ & $\left(\frac{(32.945)}{322.944)}\right.$ & $\frac{(16.258)}{(16.257)}$ & $\frac{(10.370)}{(10.019)}$ & & $\frac{219}{220}$ & $\mid$ & $\begin{array}{l}\frac{148.036}{174.897} \\
\end{array}$ \\
\hline 27 & 306. & & & & 306.618 & (27.312) & (32.944) & $(16.256)$ & (9.680) & & 220.425 & (74.945) & 147.762 \\
\hline 28 & & & & & & (27.3. & (32.944) & $(16.256)]$ & & & & & \\
\hline $\begin{array}{l}29 \\
30\end{array}$ & 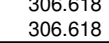 & & & & & $\begin{array}{l}(27.37 .938) \\
(27.9)\end{array}$ & $\begin{array}{l}\left(\begin{array}{l}(32.944) \\
(32.938)\end{array}\right) \\
0\end{array}$ & $\begin{array}{l}(16.25) \\
(16.241)\end{array}$ & $\left.\begin{array}{l}(9.936) \\
(2.910)\end{array}\right]$ & & $\begin{array}{l}222.011 \\
226.591\end{array}$ & 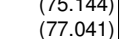 & $\begin{array}{l}144.505 \\
145.062\end{array}$ \\
\hline $\begin{array}{l}31 \\
32\end{array}$ & $\begin{array}{l}306.6 \\
3066\end{array}$ & & & & $\begin{array}{l}306.618 \\
30618\end{array}$ & (28.207) & $\begin{array}{l}(32.935) \\
(32953)\end{array}$ & $\begin{array}{l}(16.234) \\
(16.234)\end{array}$ & & & $\begin{array}{l}229.242 \\
229242\end{array}$ & \begin{tabular}{|c|}
$(77.942)$ \\
$(777942)$
\end{tabular} & $\begin{array}{l}143.901 \\
149901\end{array}$ \\
\hline 33 & 306. & & & & 306.6 & (28.207) & 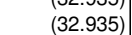 & (16.234) & & & $\begin{array}{l}2299 . \\
229 .\end{array}$ & $(77.942)$ & $\begin{array}{l}743.901 \\
143.901\end{array}$ \\
\hline $\begin{array}{l}34 \\
35\end{array}$ & $\begin{array}{l}306.6 \\
306.6\end{array}$ & & & & & (28.2077) & $\left(\begin{array}{l}(32.935) \\
(32095)\end{array}\right.$ & $\left(\begin{array}{l}(16.234) \\
(16234)\end{array}\right.$ & & & & (77.942) & 143.901 \\
\hline Total & 9.454 .051 & & & (25.749) & 9.428 .303 & $(757.513)$ & $(1.011 .743)$ & $(501.161)$ & $(1.1 .69 .656)$ & $(1.028 .131)$ & 4.940 .099 & $(1.691 .287)$ & 5.237.227 \\
\hline
\end{tabular}


CICAEENDIMENTO PROTÓTIPO

FLUXX IMPLANTAÇAO + OPERAÇAO
Valores em R $\$$ base mil

\begin{tabular}{|c|c|c|c|c|c|c|c|c|c|c|c|c|c|c|c|c|}
\hline \multirow[b]{2}{*}{ Ano Ref. } & \multirow[b]{2}{*}{$\begin{array}{c}\text { Receita } \\
\text { ACR }\end{array}$} & \multirow[b]{2}{*}{$\begin{array}{c}\text { Receita } \\
\text { ACL }\end{array}$} & \multirow[b]{2}{*}{$\begin{array}{c}\text { Receita } \\
\text { Transf. MRE }\end{array}$} & \multirow[b]{2}{*}{$\begin{array}{c}\text { Receita } \\
\text { Transf. SPOT } \\
\end{array}$} & \multirow[b]{2}{*}{$\begin{array}{c}\text { Receita } \\
\text { Bruta }\end{array}$} & \multirow[b]{2}{*}{$\begin{array}{l}\text { Impostos } \\
\text { s/ receita }\end{array}$} & \multirow[b]{2}{*}{$\begin{array}{l}\text { Encargos } \\
\text { Setoriais } \\
\end{array}$} & \multirow[b]{2}{*}{\begin{tabular}{|c|}
$\begin{array}{c}\text { Custos } \\
\text { Operacionais }\end{array}$ \\
\end{tabular}} & \multirow[b]{2}{*}{$\begin{array}{c}\text { Cta Reserva } \\
\text { BNDES }\end{array}$} & \multirow[b]{2}{*}{ FRA } & \multirow[b]{2}{*}{$\mathrm{IR} / \mathrm{CS}$} & \multirow{2}{*}{\begin{tabular}{|c|} 
\\
$\begin{array}{c}\text { Mov. Financ. } \\
\text { Operação }\end{array}$ \\
\end{tabular}} & \multirow{2}{*}{\begin{tabular}{|l} 
Mov. Financ. \\
Implantação
\end{tabular}} & \multirow[b]{2}{*}{ Total } & \multicolumn{2}{|c|}{ FLUXO EMPREENDEDOR } \\
\hline & & & & & & & & & & & & & & & $\begin{array}{l}\text { Investi- } \\
\text { mentos }\end{array}$ & Retorno \\
\hline $\begin{array}{l}1 \\
2 \\
3 \\
4 \\
5\end{array}$ & 255.515 & & & (25.749) & 229.766 & $\begin{array}{r}- \\
- \\
- \\
(12.397)\end{array}$ & $\begin{array}{r}- \\
- \\
- \\
(22.676)\end{array}$ & $(11.617)$ & $\begin{array}{r}- \\
- \\
\end{array}$ & $\begin{array}{r}- \\
- \\
- \\
(7.399)\end{array}$ & $\begin{array}{r}- \\
- \\
- \\
(7.217)\end{array}$ & 161.006 & $\begin{array}{l}(82.212) \\
(66.455) \\
(87.166) \\
(99.413) \\
(67.245)\end{array}$ & \begin{tabular}{r||}
$(82.212)$ \\
$(66.455)$ \\
$(87.166)$ \\
$(99.413)$ \\
93.761
\end{tabular} & $\begin{array}{l}(82.212) \\
(66.455) \\
(87.166) \\
(99.413)\end{array}$ & $\begin{array}{r}- \\
93.761\end{array}$ \\
\hline$\frac{5}{6}$ & 306.618 & - & & & 306.618 & (15.437) & $(33.063)$ & (16.553) & $\frac{(1.4024)}{(16.824)}$ & (7.399) & & 217.341 & (191.298) & 26.043 & & 26.043 \\
\hline 7 & 306.618 & & & & 306.618 & (15.869) & (33.059) & $(16.542)$ & 568 & (7.399) & (415) & 233.901 & (208.083) & 25.818 & & 25.818 \\
\hline 8 & 306.618 & - & & & 306.618 & $(16.286)$ & $(33.054)$ & (16.532) & 582 & (7.399) & $(3.150)$ & 230.778 & (201.256) & 29.522 & & 29.522 \\
\hline 9 & 306.618 & & & & 306.618 & (16.689) & $(33.050)$ & $(16.522)$ & 597 & (7.399) & $(5.867)$ & 227.688 & (194.374) & 33.314 & & 33.314 \\
\hline 10 & 306.618 & - & & - & 306.618 & $(19.750)$ & (33.020) & (16.445) & 612 & (7.399) & (14.865) & 215.751 & (187.308) & 28.443 & & 28.443 \\
\hline 11 & 306.618 & & & & 306.618 & $(21.326)$ & $(33.004)$ & (16.406) & 628 & (7.399) & (28.877) & 200.233 & $(180.272)$ & 19.961 & & 19.961 \\
\hline 12 & 306.618 & & & & 306.618 & $(21.559)$ & (33.002) & $(16.400)$ & 644 & (7.399) & (32.473) & 196.429 & (173.238) & 23.190 & & 23.190 \\
\hline 13 & 306.618 & & & & 306.618 & $(21.784)$ & (32.999) & $(16.394)$ & 659 & (7.399) & $(35.836)$ & 192.864 & (166.144) & 26.721 & & 26.721 \\
\hline 14 & 306.618 & & & & 306.618 & $(22.001)$ & (32.997) & $(16.389)$ & 676 & (7.399) & $(39.197)$ & 189.310 & (158.986) & 30.324 & & 30.324 \\
\hline 15 & 306.618 & & & & 306.618 & $(25.307)$ & (32.964) & $(16.306)$ & 692 & $(7.399)$ & $(52.966)$ & 172.367 & (151.684) & 20.682 & & 20.682 \\
\hline 16 & 306.618 & & & & 306.618 & $(26.901)$ & (32.948) & $(16.267)$ & 709 & (7.399) & $(60.997)$ & 162.815 & $(144.382)$ & 18.433 & & 18.433 \\
\hline 17 & 306.618 & & & & 306.618 & $(26.945)$ & (32.948) & $(16.265)$ & 726 & (7.399) & $(63.843)$ & 159.943 & (137.051) & 22.892 & & 22.892 \\
\hline 18 & 306.618 & & & & 306.618 & $(26.988)$ & (32.947) & $\begin{array}{l}(16.264) \\
\end{array}$ & 743 & (7.399) & $(66.710)$ & 157.053 & (129.652) & 27.400 & & 27.400 \\
\hline 19 & 306.618 & & & & 306.618 & $(27.029)$ & (32.947) & $\begin{array}{l}(16.263) \\
\end{array}$ & 5.525 & (7.399) & $(69.388)$ & 159.117 & (103.127) & 55.989 & & 55.989 \\
\hline 20 & 306.618 & & & & 306.618 & $\begin{array}{l}(27.069) \\
\end{array}$ & $\begin{array}{l}(32.947) \\
\end{array}$ & $\begin{array}{l}\text { (16.262) } \\
\end{array}$ & $\begin{array}{r}10.919 \\
\end{array}$ & $\begin{array}{l}(7.399) \\
\end{array}$ & $\begin{array}{l}(71.446) \\
\end{array}$ & 162.414 & $\begin{array}{r}(58.118) \\
\end{array}$ & $\begin{array}{r}104.296 \\
\end{array}$ & & $\begin{array}{r}104.296 \\
\end{array}$ \\
\hline 21 & 306.618 & & & & 306.618 & $(27.107)$ & $(32.946)$ & $(16.261)$ & & (7.399) & $(73.079)$ & 149.824 & (53.693) & $\begin{array}{r}66.132 \\
\end{array}$ & & 96.132 \\
\hline 22 & 306.618 & & & & 306.618 & $(27.145)$ & (32.946) & (16.260) & - & $(7.399)$ & (74.382) & 148.486 & & 148.486 & & $\begin{array}{r}148.486 \\
\end{array}$ \\
\hline 23 & 306.618 & - & & & 306.618 & $(27.180)$ & (32.945) & $\begin{array}{l}(16.260) \\
\end{array}$ & - & (7.399) & (74.502) & 148.331 & - & 148.331 & & 148.331 \\
\hline 24 & 306.618 & & & & 306.618 & $(27.215)$ & (32.945) & $(16.259)$ & - & (7.399) & (74.619) & 148.181 & & 148.181 & & 148.181 \\
\hline 25 & 306.618 & & & & 306.618 & $(27.249)$ & (32.945) & $(16.258)$ & - & $(7.399)$ & $(74.731)$ & 148.036 & - & 148.036 & & 148.036 \\
\hline 26 & 306.618 & & & & 306.618 & $(27.281)$ & $(32.944)$ & (16.257) & & $(7.399)$ & $(74.840)$ & 147.897 & & $\begin{array}{l}147.897 \\
\end{array}$ & & 147.897 \\
\hline 27 & 306.618 & & & & 306.618 & $(27.312)$ & (32.944) & $(16.256)$ & - & $(7.399)$ & (74.945) & 147.762 & - & 147.762 & & 147.762 \\
\hline 28 & 306.618 & & & & 306.618 & $\begin{array}{l}(27.343) \\
\end{array}$ & (32.944) & (16.256) & - & (7.399) & $\begin{array}{l}(75.046) \\
\end{array}$ & 147.631 & - & 147.631 & & 147.631 \\
\hline 29 & 306.618 & & & & 306.618 & (27.372) & (32.944) & $(16.255)$ & - & $(7.399)$ & $(75.144)$ & 147.505 & - & 147.505 & & 147.505 \\
\hline 30 & 306.618 & & & & $\begin{array}{r}306.618 \\
\end{array}$ & $\begin{array}{l}(27.938) \\
\end{array}$ & $(32.938)$ & $\begin{array}{l}(16.241) \\
\end{array}$ & & $(7.399)$ & (77.041) & 145.062 & & 145.062 & & 145.062 \\
\hline 31 & 306.618 & & & & 306.618 & $(28.207)$ & $(32.935)$ & $(16.234)$ & - & $(7.399)$ & $(77.942)$ & 143.901 & - & 143.901 & & 143.901 \\
\hline 32 & 306.618 & & & & 306.618 & $(28.207)$ & (32.935) & $(16.234)$ & - & $(7.399)$ & (77.942) & 143.901 & & 143.901 & & 143.901 \\
\hline 33 & 306.618 & & & & 306.618 & $(28.207)$ & (32.935) & (16.234) & - & (7.399) & $(77.942)$ & 143.901 & - & 143.901 & & 143.901 \\
\hline 34 & 306.618 & & & & 306.618 & $(28.207)$ & (32.935) & (16.234) & - & (7.399) & $(77.942)$ & 143.901 & & 143.901 & & 143.901 \\
\hline 35 & 306.618 & & & & 306.618 & $(28.207)$ & $(32.935)$ & (16.234) & & $(7.399)$ & $(77.942)$ & 143.901 & & 143.901 & & 143.901 \\
\hline Total & 9.454 .051 & & & (25.749) & 9.428.303 & (757.513) & (1.011.743) & (501.161) & - & (229.371) & (1.691.287) & 5.237.227 & $(2.841 .159)$ & 2.396 .068 & (335.247) & 2.731 .315 \\
\hline
\end{tabular}




\section{REFERÊNCIAS}

ABREU, Y. V. A reestruturação do setor elétrico brasileiro: questões e perspectivas. 1999. 168 f. Dissertação (Mestrado) - Escola Politécnica, Universidade de São Paulo, São Paulo, 1999.

AGÊNCIA NACIONAL DE ENERGIA ELÉTRICA. Estabelece os procedimentos gerais para registro e aprovação dos estudos de inventário hidrelétrico de bacias hidrográficas. Resolução n. 393, de 04 de dezembro de 1998. Diário Oficial da União, Brasília, 7 dez. 1998. Seção 1, v. 136, n. 234, p. 44.

Tarifas de fornecimento de energia elétrica. Brasília, 2005a. (Cadernos temáticos ANEEL, 4).

Fixa o valor da tarifa atualizada de referência - TAR para o cálculo da compensação financeira pelo uso dos recursos hídricos. Resolução normativa n. 192, de 19 de dezembro de 2005. Diário Oficial da União, Brasília, 22 dez. 2005b. Seção 1, v.142, n. 245, p. 85. Disponível em: <http://www.aneel.gov.br/cedoc/ren2005192.pdf>. Acesso em: 26 dez. 2006.

.Contratação de energia proveniente de novos empreendimentos, com posterior outorga de concessão ou autorização, dos empreendimentos enquadrados nos termos do artigo 17 da lei n. 10.848, de 15 de março de 2004, para o sistema interligado nacional - SIN, no ambiente de contratação regulada - ACR. Edital de leilão n.002/2005 ANEEL, Brasília, 2005c. 54 p.

Detalhamento da sistemática para o leilão de energia proveniente de novos empreendimentos de geração. Despacho n. 1.809, de 10 de novembro de 2005. Edital de leilão n.002/2005 ANEEL. Brasília, 2005d. 38 p.

Homologa a curva do custo do déficit de energia elétrica e os limites mínimo e máximo do preço do mercado de curto prazo. Resolução homologatória n. 267, de 19 de dezembro de 2005. Diário Oficial da União, Brasília, 25 dez. 2005e. Seção 1, v. 142, n. 246. p. 132. Disponível em: <http://www.aneel.gov.br/cedoc/reh2005267.pdf>. Acesso em: 26 dez. 2006

Fixa o valor anual da taxa de fiscalização de serviços de energia elétrica - TFSEE, para as concessionárias de geração e de transmissão de serviço público, autoprodutores e produtores independentes de energia elétrica, relativo ao exercício de 2006. Despacho n. 2.268, de 29 de dezembro de 2005. Diário Oficial da União, Brasília, 30 dez. 2005f. Seção 1, v. 142, n. 251, p. 232. Disponível em: <http://www.aneel.gov.br/cedoc/dsp20052268.pdf>. Acesso em: 26 dez. 2006. 
Fixa o valor das tarifas de uso do sistema de transmissão de energia elétrica, componentes da Rede Básica do Sistema Interligado Nacional - SIN e a tarifa de transporte da energia elétrica proveniente de Itaipu Binacional, bem como extingue a tarifa de uso do sistema de transmissão da Rede Básica, vinculada aos contratos iniciais ou equivalentes. Resolução homologatória n. 354, de 27 de junho de 2006a. Diário Oficial da União, Brasília, 30 jun. 2006. Seção 1, v. 143, n. 124, p. 259. Disponível em: <http://www.aneel.gov.br/cedoc/reh2006354.pdf>. Acesso em: 26 dez. 2006.

Contratação de energia proveniente de novos empreendimentos, com posterior outorga de autorização, e dos empreendimentos enquadrados nos termos do art. 17 da lei no 10.848, de 15 de março de 2004, para o sistema interligado nacional - SIN, no ambiente de contratação regulada - ACR. Edital de leilão, n. 002/2006 ANEEL, Brasília, 2006b. 41 p.

Detalhamento da sistemática para o leilão de energia proveniente de novos empreendimentos de geração. Edital de leilão, n. 002/2006, Brasília, 2006c. 28 p.

Contratação de energia proveniente de novos empreendimentos. Edital de leilão n. 004/2006, Brasília, 2006d. 26 p.

Detalhamento da sistemática para o leilão de energia proveniente de novos empreendimentos de geração. Edital de leilão n. 004/2006. Brasília, 2006e. 46 p.

ALENCAR, C. T. Derivação de fundos para investimentos em empreendimentos de infra-estrutura no Brasil: a viabilidade da securitização nas concessões rodoviárias e de geração independente de energia hidrelétrica. 1998. 281 f. Tese (Doutorado) - Escola Politécnica, Universidade de São Paulo, São Paulo,1998.

ARIZTÍA, R.; WATTS, D. The electricity crises of California, Brazil and Chile: lessons to the Chilean market. In: LESCOPE'2002, THE 2002 LARGE ENGINEERING SYSTEMS CONFERENCE ON POWER ENGINEERING, 2002, Santiago, Chile. [Trabalhos apresentados]. Santiago, Chile, 2002. p. 7-12.

BANCO NACIONAL DE DESENVOLVIMENTO ECONÔMICO E SOCIAL. Taxa de juros de longo prazo - TJLP. Rio de Janeiro, 2006a. Disponível em:

$<$ http://www.bndes.gov.br/produtos/custos/juros/tjlp.asp>. Acesso em: $13 \mathrm{dez} .2006$.

Apresenta informações sobre o programa FINEM - Financiamento a

Empreendimentos. Disponível em: $<$ http://www.bndes.gov.br/linhas/finem.asp $>$. Acesso em: 13 set.2006b. 
BARROSO, L. A.; BLANCO, A.; RUDNICK, H. Twenty years of restructuring and reform in Argentina, Brazil and Chile. IEEE Power \& Energy Magazine, New York, p.50-59, Jul/Ago. 2005.

BEHR, P. Papers Show That Enron Manipulated Calif. Crisis. The Washington Post. 07 de maio. 2002.

BOLSA DE VALORES DE SÃO PAULO. Comissão de Valores Mobiliários. Dispõe sobre a constituição, o funcionamento e a administração dos fundos de investimento em participações. Instrução CVM n. 391, de 16 de julho de 2003. Disponível em: <http://www.bovespa.com.br/Pdf/Instrucao_391.pdf>. Acesso em: 12 ago. 2005.

BONOMI, C. A.; MALVESSI, O. Project finance no Brasil: fundamentos e estudos de casos. São Paulo: Atlas, 2002. 363 p.

BORGES, L.F.X. Covenants: instrumentos de garantia em project finance. Revista do BNDES, Rio de Janeiro, v. 6, n. 11, p. 117-135, jun. 1999a.

BRASIL. Ministério das Minas e Energia. Modelo institucional do setor elétrico. Brasília, 2003. 60 p. Disponível em: <http://ucel.eln.gov.br/gse_doc/Modelo_Energia.pdf $>$. Acesso em: 15 abr. 2004.

Lei n. 10.847, de 15 de março de 2004. Autoriza a criação da empresa de pesquisa energética - EPE e dá outras providências. Diário Oficial da União, Brasília, 16 mar. 2004a. Seção 1, v. 141, n. 51, p. 1.

Lei n. 10.848, de 15 de março de 2004. Dispõe sobre a comercialização de energia elétrica, altera leis anteriores, e dá outras providências. Diário Oficial da União, Brasília, 16 mar. 2004b. Seção 1, v. 141, n. 51, p.2.

Decreto n. 5.163, de 30 de julho de 2004. Regulamenta a comercialização de energia elétrica, o processo de outorga de concessões de autorizações de geração de energia elétrica, e dá outras providências. Diário Oficial da União, Brasília, 30 jul. 2004c. Seção 1, v. 141, n. 146-A, p. 1.

Lei n. 9.074, de 07 de julho de 1995. Estabelece normas para outorga e prorrogações das concessões e permissões de serviços públicos e dá outras providências. Diário Oficial da União, Brasília, 8 jul. 2005. Seção 1, p. 10.125. 
. Ministério de Minas e Energia. Empresa de Pesquisa Energética. Estatística e análise do mercado de energia elétrica: boletim mensal (mês base: dezembro 2005). Rio de Janeiro, 2006a. Disponível em:<http://www.epe.gov.br/default.aspx\#>. Acesso em: 29 mar.2006.

Ministério de Minas e Energia. Empresa de Pesquisa Energética. Plano nacional de energia 2030: geração hidrelétrica. Brasília, abr. 2006b. Disponível em: $<$ http://www.cogensp.com.br/cogensp/workshop/2006/P1_Nac_Ener_2030_27042006.pdf > .

Acesso em: 05 mar. 2006.

Plano decenal de expansão de energia elétrica 2006-2015. Brasília, 2006c Disponível em:<http://epe.gov.br/Lists/Estudos/DispForm.aspx?ID=8 $>$. Acesso em: 23 jul. 2006

CÂMARA DE COMERCIALIZAÇÃO DE ENERGIA ELÉTRICA. Informações sobre mecanismo de realocação de energia, liquidação de diferenças contratuais no mercado de curto prazo e leilões de energia nova. Disponível em: <http://www.ccee.org.br>. Acesso em: 12 dez. 2005.

CASTRO, R. Análise de decisões sob incertezas para investimentos e comercialização de energia elétrica no Brasil. 2004. 183 f. Tese (Doutorado) - Universidade Estadual de Campinas, Campinas, 2004.

DELOITTE TOUCHE TOMATSU EMERGING MARKETS. Sustainable power sector reform in emerging markets: financial issues and options. Washington, D.C.: Joint World Bank/USAID Policy Paper, Jun. 2004. 188 p. (Final draft).

FARIA, V. C. S. O papel do project finance no financiamento de projetos de energia elétrica: caso da UHE Cana Brava. 2003. 169 f. Dissertação (Mestrado) - Universidade Federal do Rio de Janeiro, Rio de Janeiro, 2003.

FINNERTY. J. D. Project finance: engenharia financeira baseada em ativos. Rio de Janeiro: Qualitymark, 1998. 355 p.

GIAMBIAGI, F.; PIRES, J. C. L. Retorno dos novos investimentos privados em contextos de incerteza: uma proposta de mudança do mecanismo de concessão de rodovias no Brasil. Rio de Janeiro: BNDES, 2000. 40 p. (Texto para discussão, 81). 
; SALES, A. F. As perspectivas do setor elétrico após o racionamento. Revista do BNDES, Rio de Janeiro, v.9, n.18, p.163-204, dez. 2002.

MEDINA; H. Governo vê risco de aumento de preço. Folha de São Paulo, 26 de dez. 2006a. Dinheiro, p. B5.

Termelétricas oferecem menos energia. Folha de São Paulo, 30 de dez. 2006b, Dinheiro, p. B3.

MERRILL LINCH. China, Índia \& Brazil: Overpowering Growth. Nova Iorque, jan. 2007. 64 p.

OPERADOR NACIONAL DO SISTEMA ELÉTRICO. Cálculo da energia e potência asseguradas de aproveitamentos hidroelétricos: submódulo 7.8. Rio de Janeiro, 2000. Disponível em: <http://www.ons.org.br/download/procedimentos/submodulo07-08-r2.pdf $>$. Acesso em: 09 jun.2006.

PIRES, J. C. L. Políticas regulatórias no setor de energia elétrica: a experiência dos Estados Unidos e da União Européia. Rio de Janeiro: BNDES, 1999. 59 p. (Texto para discussão, 73).

Desafios da reestruturação do setor elétrico brasileiro. Rio de Janeiro: BNDES, 2000. 45 p. (Texto para discussão, 76).

ROCHA LIMA JR., J. da. Securitização de portfólios de base imobiliária. São Paulo: EPUSP, 1993. 23 p. (Boletim Técnico da Escola Politécnica da Usp. Departamento de Engenharia de Construção Civil, BT/PCC/99).

O conceito de taxa de retorno. São Paulo: EPUSP, 1996. 64 p. (Boletim Técnico da Escola Politécnica da Usp. Departamento de Engenharia de Construção Civil, BT/PCC/158).

Decidir sobre investimentos no setor da construção civil. São Paulo: EPUSP, 1998. 72 p. (Boletim Técnico da Escola Politécnica da USP. Departamento de Engenharia de Construção Civil, BT/PCC/200).

Análises em project finance: a escolha da moeda de referência. São Paulo: EPUSP, 1999a. (Texto Técnico. Escola Politécnica da USP. Departamento de Engenharia de Construção Civil, TT/PCC/21). 
Novos produtos financeiros e o mercado imobiliário: investimento via títulos de securitização. São Paulo: 1999b. 25 p.

Análise econômica de empreendimentos de longo horizonte de maturação: indicadores avançados para análise da qualidade do investimento. São Paulo: EPUSP, 2001. 24 p. (Boletim Técnico da Escola Politécnica da USP, Departamento de Engenharia de Construção Civil, BT/PCC/271).

RUDNICK, H. Risk responsibility for supply in deregulated electricity markets - the Chilean case. Santiago, Chile: Catolic University of Chile, jul. 2003. 4 p. Disponível em: $<$ http://www2.ing.puc.cl/power/paperspdf/RudnickChileToronto03.pdf $>$. Acesso em: 17 jan. 2006.

SALES, C. J. D. Leilões de energia: o rei está nu. São Paulo: Câmara Brasileira de Investidores em Energia Elétrica, mar.2006. 2 p. Disponível em: $<$ http://www.acendebrasil.com.br/archives/files/20060320\%20\%20Leil\%C3\%B5es\%20de\%20Energia\%20\%20-\%20CE.pdf>. Acesso em: 01 abr.06.

SCHUMAHER, L.M. Manutenção e Reposição do Equilíbrio Econômico- Financeiro dos Contratos de Concessões de Rodovias: Avaliação das Revisões e reajustes de Tarifas no Brasil. 2003. 128 f. Dissertação (Mestrado) - Escola Politécnica, Universidade de São Paulo, São Paulo, 2003

U.S DEPARTMENT OF ENERGY. International energy outlook 2003: energy plug. Monthly Energy Review, Washington, D.C, 22 p, May 2003. Disponível em:<http://www.findarticles.com/p/articles/mi_m2744/is_5_2003/ai_104211737>. Acesso em: 14 fev. 2005. 


\section{REFERÊNCIAS COMPLEMENTARES}

AHMED, P. A.; FANG, X. Project finance in developing countries: IFC's lessons of experience. Washington, D.C: IFC, c1999. 102 p. (Lessons of experience series, 4).

ALENCAR, C. T. Highway concessions in Brazil: an analysis towards the feasibility of the securitization. Journal of Financial Management for Property and Construction, Glasgow, UK, v. 5, n. 3, p.159-172, dec. 2000.

.; AGUIAR FILHO, F.L. Risk Mitigation for the Private Power Projects Investors in Brazil - The Guarantees Structure. In: CIB W107. CONSTRUCTION IN DEVELOPING ECONOMIES INTERNATIONAL SYMPOSIUM "CONSTRUCTION IN DEVELOPING ECONOMIES: NEW ISSUES AND CHALLENGES”, 2006, Santiago, Chile.

.; MONETTI, E. An analysis of present brazilian concession contracts: the case of highways operation. In: CIB W92. PROCUREMENT SYSTEMS SYMPOSIUM. INFORMATION AND COMMUNICATION IN CONSTRUCTION PROCUREMENT, 2000, Santiago, Chile. Anais... Santiago, Chile, 2000. p.171-181.

AMATUZZI, B. D.; GORDON, S. A utilização de fundos de investimento em direitos creditórios (FIDCS) em projetos de parceria público-privada (PPP). São Paulo: Pinheiro Neto Advogados, 2005. 3 p.

BATISTA, J. C. O BNDES e o desenvolvimento brasileiro. In: SEMINÁRIO ESPECIAL: 50 ANOS DE DESENVOLVIMENTO: O PAPEL DO BNDES E DO BANCO DO NORDESTE 1952/2002, 2002, Rio de Janeiro. [Trabalhos apresentados]. Rio de Janeiro, 2002. 30p.

BERNARDINO, A. P. S. Fontes de recursos e atuação do BNDES sob uma perspectiva histórica. Revista do BNDES, Rio de Janeiro, v. 12, n. 23, p. 53-72, jun. 2005.

BORBA, J. E. T. Das debêntures. Rio de Janeiro: Renovar, 2005. 205 p.

BORGES, L. F. X. Project finance e infra-estrutura: descrição e críticas. Revista do BNDES, Rio de Janeiro, v. 5, n. 9, p. 105-122, jun. 1998.

Securitização como parte da segregação de risco. Revista do BNDES, Rio de Janeiro, v. 6, n. 12, p. 123-136, dez. 1999. 
.; FARIA, V. C. S. Project finance: considerações sobre a aplicação em infra-estrutura no Brasil. Revista do BNDES, Rio de Janeiro, v. 9, n. 18, p. 241-280, dez. 2002.

BORGES, L. F. X; LOPES, L. M. P. B. Os valores mobiliários e a captação de empréstimos no mercado financeiro doméstico. Revista do BNDES, Rio de Janeiro, v. 8, n. 15, p. 289-308, jun. 2001.

; _ـ Parceria público-privada: riscos e mitigação de riscos em operações estruturadas de infra-estrutura. Revista do BNDES, Rio de Janeiro, v. 12, n. 23, p. 73-118, jun. 2005.

.; SERRÃO, C. F. B. Aspectos de governança corporativa moderna no Brasil. Revista do BNDES, Rio de Janeiro, v. 12, n. 24, p. 11-148, dez. 2005.

CARVALHO, J. C. et al. Impactos fiscais da crise de energia elétrica: 2001 e 2002. Rio de Janeiro: IPEA, ago. 2001. 34 p. (Texto para discussão, 816).

CASTRO, R.; RAMOS, D. S.; LYRA FILHO, C. Comercialização de energia no ambiente competitivo do setor elétrico brasileiro. In: SEMINÁRIO NACIONAL DE PRODUÇÃO E TRANSMISSÃO DE ENERGIA ELÉTRICA, 15., 1999, Foz do Iguaçu. Anais... Foz do Iguaçu: CIGRE, 1999. 6 p.

CHIARA, P. C. Análise da viabilidade econômica, pela iniciativa privada de investimentos em infra-estrutura e operação do serviço público de transportes rodoviários, sob o regime de concessão. 1996. 134 f. Dissertação (Mestrado) - Escola Politécnica, Universidade de São Paulo, São Paulo, 1996.

COSTA, M.; ZANIBONI, M. Um retrato do novo modelo do setor elétrico brasileiro. São Paulo: Standard \& Poor's, out. 2004. 5 p. (Brasil - Relatório Standard \& Poor's).

DAVID, P. A.; MOREIRA, A. R. B; ROCHA, K. Regulação do preço da energia elétrica e viabilidade do investimento em geração no Brasil. Rio de Janeiro: IPEA, agosto 2003. 22 p. (Texto para discussão, 978).

GOLDEMBERG, J.; MIELNIK, O. Electricity regulatory reform and sustainable development in Latin America. Energy for Sustainable Development, Bangalore, v. 3, n. 7, p. 17-26, mar.1997. 
GUEDES FILHO, E. M.; CAMARGO, J. M. Setor elétrico brasileiro: cenários de crescimento e requisitos para a retomada de investimentos. São Paulo: Tendências Consultoria Integrada, 2003. 204 p.

JECHOUTEK, K. G.; LAMECH, R. Private power financing: from project finance to corporate finance. Private Sector,Washington, D.C., n. 56, out. 1995. Disponível em: < http://rru.worldbank.org/Documents/PublicPolicyJournal/056lamech.pdf $>$. Acesso em: 18 fev. 2006.

MACIEL, C. S.; VILLELA, A. V. A regulamentação do setor de infra-estrutura econômica: uma comparação internacional. Brasília: IPEA, 1999. 110 p. (Texto para discussão, 684).

MONTERO,J. P.; MORENO, R.; RUDNICK, H. Energy supply auctions to stimulate generation investment. Chile: Catolic University of Chile, 2005. 8 p. Disponível em: < http://www2.ing.puc.cl/power/publications/deregulation.htm>. Acesso em: 07 mar. 2006.

.; RUDNICK, H. Second generation electricity reforms in Latin America and the California paradigm. Journal of Industry, Competition and Trade, Holanda, n. 2, p. 159$172,2002$.

PIRES, J. C. L. Capacitação, eficiência e abordagens regulatórias contemporâneas no setor energético brasileiro: as experiências da ANEEL e da ANP. Rio de Janeiro: BNDES, 1999. 23 p. (Ensaios BNDES, 11).

O processo de reformas do setor elétrico brasileiro. Revista do BNDES, Rio de Janeiro, v. 6, n. 12, p. 137-168, dez. 1999.

.; PICCININI, M. S. Mecanismos de regulação tarifária do setor elétrico: a experiência internacional e o caso brasileiro. Rio de Janeiro: BNDES, 1998. 32 p. (Texto para discussão, 64).

;GOSTKORZEWICZ, J.;GIMBIAGI, F. O cenário macroeconômico e as condições de oferta de energia elétrica no Brasil. Rio de Janeiro: BNDES, 2001. 46 p. (Texto para discussão, 85).

RAMOS, D. S.; FADIGAS, E.; LIMA, W. S. Financial risks for project finance in natural gás thermal generation in Brazil. In: WORLD ENERGY CONGRESS, 18., 2001, Buenos Aires. World Energy Council. Buenos Aires: WEC, 2001. 
RIECHE, F. C. Gestão de riscos em fundos de pensão no Brasil: situação da legislação e perspectivas. Revista do BNDES, Rio de Janeiro, v. 12, n. 23, p. 219-242, jun. 2005.

ROCHA LIMA JR., J. da. Fundos de investimento imobiliário e títulos de investimento de base imobiliária. São Paulo: EPUSP, 1994. 33 p. (Boletim Técnico da Escola Politécnica da Usp. Departamento de Engenharia de Construção Civil, BT/PCC/130).

Os sistemas operacionais para securitização de portfólios imobiliários e de base imobiliária via debêntures. São Paulo: EPUSP, 1997. 85 p. (Boletim Técnico da Escola Politécnica da USP. Departamento de Engenharia de Construção Civil, BT/PCC/186).

RODRIGUES JR., W. A participação privada no investimento em infra-estrutura e o papel do project finance. Brasília: IPEA, jul. 1997. 73 p. (Texto para discussão, 495).

STRONG, J. S.; GUASCH, J. L.; BENAVIDES, J. Managing risks of infrastructure investment in Latin America: lessons, issues, and prescriptions. Washington, D.C.: InterAmerican Development Bank; Sustainable Development Department, 2004. 23 p. 